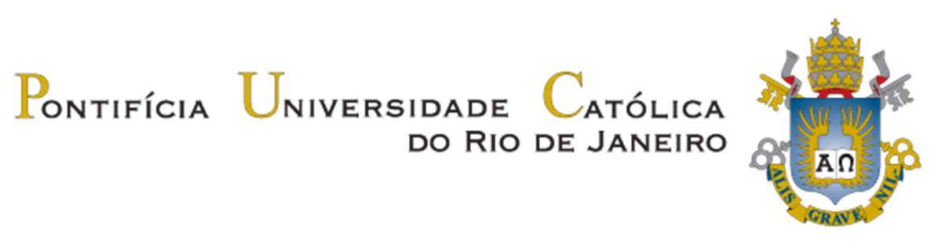

Flávia Martins da Rosa Pereira da Silva

Diferenciações de gênero na caracterização de personagens: uma proposta metodológica e primeiros resultados

Dissertação de Mestrado

Dissertação apresentada como requisito parcial para obtenção do grau de Mestre em Letras/Estudos da Linguagem pelo Programa de Pós-Graduação em Estudos da Linguagem do Departamento de Letras da PUC-Rio.

Orientadora: Profa. Maria Cláudia de Freitas

Rio de Janeiro

Abril de 2021 

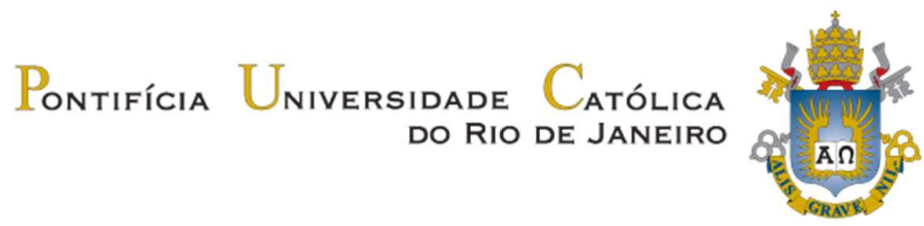

Flávia Martins da Rosa Pereira da Silva

\section{Diferenciações de gênero na caracterização de personagens: uma proposta metodológica e primeiros resultados}

Dissertação apresentada como requisito parcial para obtenção do grau de Mestre pelo Programa de PósGraduação em Estudos da Linguagem do Departamento de Letras da PUC-Rio. Aprovada pela Comissão Examinadora abaixo:

Profa. Maria Cláudia de Freitas

Orientadora

Departamento de Letras - PUC-Rio

Profa. Liana de Andrade Biar Departamento Letras - PUC-Rio

Profa. Diana Maria de Sousa Marques Pinto dos Santos University of Oslo

Prof. Emanoel Cesar Pires de Assis

UEMA

Rio de Janeiro, 9 de abril de 2021. 
Todos os direitos reservados. A reprodução, total ou parcial, do trabalho é proibida sem autorização da universidade, da autora e da orientadora.

\section{Flávia Martins da Rosa Pereira da Silva}

Graduou-se em Letras (Português-Alemão) pela Faculdade de Letras da Universidade Federal do Rio de Janeiro e é Especialista em Língua Portuguesa pelo Liceu Literário Português.

Ficha Catalográfica

Silva, Flávia Martins da Rosa Pereira da

Diferenciações de gênero na caracterização de personagens: uma proposta metodológica e primeiros resultados / Flávia Martins da Rosa Pereira da Silva ; orientadora: Maria Cláudia de Freitas. - 2021.

169 f. : il. color. ; $30 \mathrm{~cm}$

Dissertação (mestrado) - Pontifícia Universidade Católica do Rio de Janeiro, Departamento de Letras, 2021.

Inclui referências bibliográficas.

1. Letras - Teses. 2. Humanidades digitais. 3. Linguística de Corpus. 4. Mineração de dados textuais. 5. Análise de discurso. 6. Papéis de gênero. I. Freitas, Cláudia. II. Pontifícia Universidade Católica do Rio de Janeiro. Departamento de Letras. III. Título.

CDD:400 


\section{Agradecimentos}

Aos meus amigos, minha família e colegas de trabalho pela paciência e compreensão que tiveram diante das minhas ausências, durante a elaboração desta pesquisa e também pelo seu apoio.

À minha orientadora, Cláudia Freitas que, além de me inspirar desde o nosso primeiro encontro, foi a maior incentivadora deste trabalho e sempre acreditou que eu conseguiria.

À Ana Luíza Baruffati por continuamente me ajudar a compreender quem sou e a manter a paixão, mesmo durante os momentos mais difíceis.

À CAPES e à PUC-Rio, pelos auxílios concedidos, sem os quais este trabalho não poderia ter sido realizado.

Aos voluntários que participaram do teste do Rêve.

Aos professores que participaram da comissão examinadora.

A todos os professores e funcionários do Departamento pelos ensinamentos e pela ajuda.

A todos os professores e professoras que me inspiraram ao longo da vida a seguir o caminho das Letras, especialmente ao Luiz Montez, Álvaro Bragança, Ana Combo, Eneida Nogueira, Márcia Bandeira, Maria Lúcia Leitão Almeida e ao Professor Silvano.

O presente trabalho foi realizado com apoio da Coordenação de Aperfeiçoamento de Pessoal de Nível Superior - Brasil (CAPES) - Código de Financiamento 001. 


\section{Resumo}

Silva, Flávia Martins da Rosa Pereira da; Freitas, Maria Cláudia de (Orientadora). Representações de gênero na caracterização de personagens: uma proposta metodológica e primeiros resultados. Rio de Janeiro, 2021. 169 p. Dissertação de Mestrado - Departamento de Letras, Pontifícia Universidade Católica do Rio de Janeiro.

Este trabalho apresenta uma metodologia que propõe a combinação de dados quantitativos e distanciados com a leitura mais detalhada e aproximada em análises de discurso, oferecendo a oportunidade de novos olhares sobre os dados e diversas perspectivas de análise. A metodologia faz uso de recursos dos estudos linguísticos com corpus, tais como listas de frequência, preferência, categorização e leitura de linhas de concordância. Demonstra-se sua aplicação, tomando-se como objeto de exploração obras da literatura brasileira em domínio público compiladas em um corpus com cerca de 5 milhões de palavras, anotado semântica e morfossintaticamente, e utilizam-se ferramentas computacionais que permitem buscas com base em padrões léxico-sintáticos da língua portuguesa. O objetivo é identificar como as personagens masculinas e femininas são caracterizadas nos textos, possibilitando tanto elaborar uma visão geral de como mulheres e homens são construídos através da linguagem. $\mathrm{O}$ estudo se dá em duas frentes: observando os predicadores na descrição das personagens e as ações são desempenhadas por elas, fazendo distinção entre masculinas e femininas, comparando-as e analisando as diferenças de forma crítica.

\section{Palavras-chave}

Humanidades Digitais, Linguística de Corpus, mineração de dados textuais, análise de discurso, papéis de gênero, literatura brasileira. 


\section{Abstract}

Silva, Flávia Martins da Rosa Pereira da; Freitas, Maria Cláudia de (Advisor). Gender representations on characters' description: a methodological proposal and early results. Rio de Janeiro, 2021. 169 p. Dissertação de Mestrado - Departamento de Letras, Pontifícia Universidade Católica do Rio de Janeiro.

This work presents a methodology that proposes the combination of quantitative and distant-read data with detailed, closer reading in discourse analysis, enabling new possible views over data and diverse perspectives of analysis. This methodology makes use of resources most used in corpus-based linguistic, such as frequency lists, preferences, categorization, and reading concordance lines. Its application is demonstrated using as exploration object Brazilian literature titles in the public domain, compiled in a corpus with approximately 5 million words, semantically and morpho-syntactically annotated, and by using computational tools that enable searches based on lexical-syntactic patterns of the Portuguese language. The purpose is to identify how the male and female characters are portrayed in those texts, enabling the creation of a general view on how women and men are built through language. The study happens in two fronts: by observing the predicates used on describing characters and the actions these characters take, comparing the male and female results and analyzing them in a critical way.

\section{Keywords}

Digital Humanities, Corpus Linguistics, text data mining, discourse analysis, gender roles, Brazilian literature. 


\section{Sumário}

Lista de figuras, tabelas e gráficos ...................................................... 7

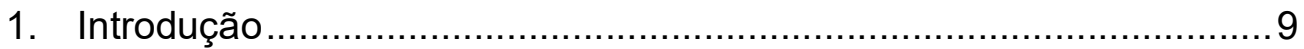

2. Perspectivas teórico-metodológicas ............................................... 11

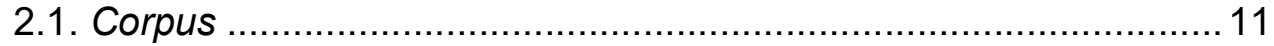

2.1.1. Corpus e Análise de Discurso ............................................. 13

2.2. Extração de informações e Mineração de dados textuais................21

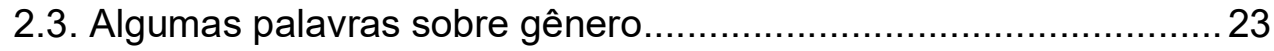

2.3.1. Definições e teorias ........................................................... 23

2.2.2. Representatividade nas artes ............................................ 25

2.2.3. Viés de gênero na linguagem ............................................. 28

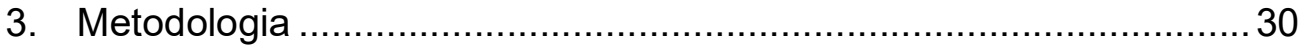

a. A escolha do corpus ............................................................... 30

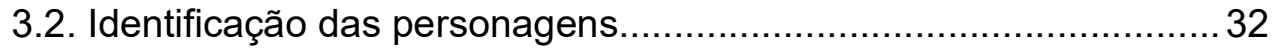

3.3. Desenvolvimento de expressões de busca por relações de

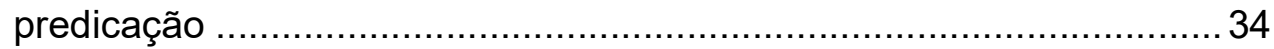

3.3.1 Resultados iniciais e criação de categorias ……………......... 50

3.3.2 Validação das categorias de análise.......................................53

3.4. Desenvolvimento de expressões de busca por ações .................... 66

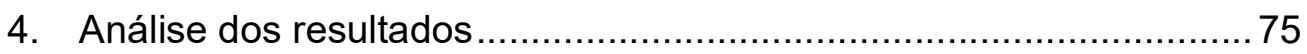

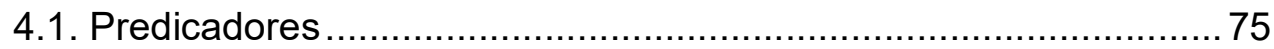

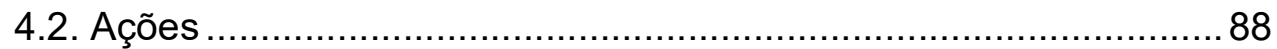

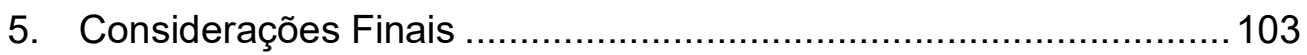

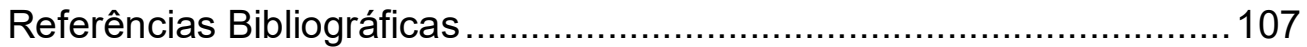

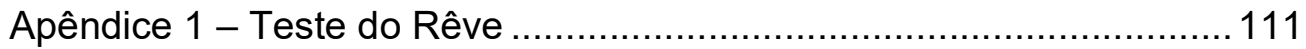

Apêndice 2 - Expressão de busca para o predicador "belo"...................116

Apêndice 3 - Expressão de busca por predicadores ............................118

Apêndice 4 - Resultado das buscas por predicadores + categorização 121

Apêndice 5 - Predicadores com múltipla categorização ........................ 139

Apêndice 6 - Expressão de busca por ações ....................................... 141

Apêndice 7 - Resultado das buscas por ações..................................... 142

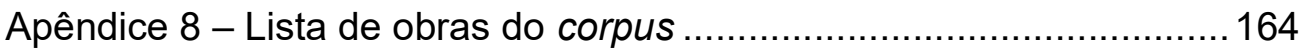




\section{Lista de figuras, tabelas e gráficos}

Tabela 1 - Frequência dos predicadores mais comuns por gênero.

Quadro 1 - Exemplos de predicadores, distribuídos por eixo semântico.

Figura 1 - Visão do teste para os participantes.

Tabela 2 - Contagem das respostas obtidas no teste do Rêve.

Gráfico 1 - Resultados do teste do Rêve: concordâncias e divergências.

Gráficos 2 e 3 - Distribuição da contagem de predicações obtidas (lemas), representando a diversidade lexical por eixo, desconsiderando o número de vezes que cada uma aparece no corpus.

Tabela 3 - Lista das vinte predicações exclusivas (lemas) mais frequentes para personagens masculinos.

Tabela 4 - Lista das vinte predicações exclusivas (lemas) mais frequentes para personagens femininos.

Gráficos 4 e 5 - Distribuição dos predicadores quanto ao gênero, pelas categorias semânticas, considerando o número de vezes que cada um ocorre.

Gráficos 6 e 7 - Distribuição dos predicadores quanto ao gênero, pelas categorias semânticas, considerando o número de vezes que cada um ocorre, excluindo erros e a categoria estado.

Figura 2 - Nuvem de palavras criada com os 30 predicadores de maior ocorrência para cada gênero. $\mathrm{O}$ tamanho das palavras é proporcional ao número de vezes que o predicador ocorre.

Tabela 5 - Lista dos predicadores comuns aos dois gêneros mais frequentes, listados por preferência.

Tabela 6 - Lista dos vinte predicadores comuns aos dois gêneros mais frequentes, listados por preferência, com indicação do eixo semântico.

Gráficos 8 e 9 - Distribuição dos predicadores quanto ao gênero, pelas quatro categorias semânticas, considerando o número de ocorrências, nas obras de Júlia Lopes de Almeida e Maria Firmina dos Reis que fazem parte do corpus. 
Tabela 7 - Lista dos predicadores comuns aos dois gêneros e seus índices de preferência, nas obras de Júlia Lopes de Almeida e Maria Firmina dos Reis.

Tabela 8 - Lista dos predicadores exclusivos a cada gênero, com mais de uma ocorrência, nas obras de Júlia Lopes de Almeida e Maria Firmina dos Reis.

Tabela 9 - Contagem dos verbos designadores de ação executada por personagens no corpus OBras.

Tabela 10 - Lista dos verbos leves identificados no corpus OBras e suas ocorrências. Tabela 11 - Verbos exclusivos para personagens femininos e masculinos, por ordem de frequência.

Tabela 12 - Lista dos verbos comuns aos dois gêneros listados por ordem de preferência (mostrando apenas os 30 mais frequentes para cada gênero).

Tabela 13 - Verbos que ocorrem o mesmo número de vezes para personagens femininas e masculinas (aqui aparecem apenas os que ocorrem mais de uma vez para cada gênero). 


\section{Introdução}

A ideia deste trabalho surgiu do desejo de fazer uma análise crítica de discurso, sem a pretensão de aderir a nenhuma vertente específica da área de estudo conhecida por este nome, desenvolvendo um método que combine de forma sinérgica as potencialidades da extração de informação, recursos dos estudos linguísticos baseados em corpus e de uma leitura distante e crítica dos dados.

Para demonstrar a aplicação desse método, utilizaremos um corpus composto por obras de literatura brasileira em domínio público, majoritariamente do século $\mathrm{XIX}$, olhando para dois pontos principais: os predicadores utilizados para caracterizar personagens e as ações que estas executam. Nosso interesse é identificar como as personalidades humanas são construídas no discurso, e como se dá a diferenciação entre os gêneros das personagens. Acreditamos que seja possível identificar nos resultados obtidos alguns vieses de gênero presentes na estrutura social brasileira. Sendo as obras que compõem nosso corpus objetos culturais, esta pesquisa também se insere na área das Humanidades Digitais, uma área interdisciplinar das ciências humanas que tira proveito do potencial oferecido pela disponibilização de objetos culturais em meios digitais.

No capítulo que se segue, iremos apresentar nossas perspectivas teórico-metodológicas, partindo da definição de corpus e suas utilizações nos estudos da linguagem. Faremos referência a trabalhos precursores nos estudos com corpus que se interessam por questões ideológicas presentes no discurso e faremos uma breve exposição do método Hearst de extração de informações. Em seguida, faremos um panorama das questões da temática de gênero que nos inspiraram a desenvolver este estudo especifico, tais como categorização, representatividade e viés.

No terceiro capítulo, iremos apresentar a metodologia desenvolvida para esta pesquisa, e como fizemos a escolha de um corpus que fosse adequado para este tipo de trabalho. Mostraremos como encontramos os 
padrões da língua que nos permitem identificar personagens no discurso, suas predicações e as ações que executam; e ainda como organizamos as ocorrências em eixos semânticos como uma forma de dar sentido ao grande número de predicadores encontrados, demonstrando ainda como foi feita a validação dessas categorias.

O quarto capítulo é dedicado à análises das distribuições lexicais das ações e predicações. Fazemos uma análise dos predicadores e ações únicas e da preferência para os que aparecem para os dois gêneros, das tendências de predicações por eixo semântico, fazendo uma combinação de métodos de leitura aproximada e leitura distante. Nossas análises são críticas e se baseiam não somente nos dados obtidos das listas, como também na observação dos contextos intra- (linhas de concordância) e extralinguístico (vivência social, conhecimento de mundo).

Nas considerações finais, listaremos as conclusões obtidas a partir deste estudo, as contribuições que acreditamos que esta metodologia possa oferecer a outros pesquisadores das questões sociais, da linguagem e do discurso e, e também a programadores preocupados com a viés implícito presente na inteligência artificial. Lançamos também algumas ideias para trabalhos futuros a serem realizados utilizando a mesma metodologia, expandindo seu alcance. 


\section{Perspectivas teórico-metodológicas}

\subsection{Corpus}

Um corpus é um grande conjunto de enunciados ou textos, que representa uma fonte de material linguístico ocorrido naturalmente. O que em inglês se denominda Corpus Linguistics ${ }^{1}$ é o estudo da linguagem com base em um conjunto de textos em formato digital e com o auxílio de ferramentas computacionais (McEnery \& Hardie, 2012), e deveria ser vista como uma metodologia em vez de uma área independente da linguística (McEnery \& Wilson, 2001), sendo, portanto, compatível com diversas abordagens, sem barreiras de tradições disciplinares (Mautner, 2009). Geralmente, os corpora com que trabalhamos são muito grandes, com milhões de palavras; o tamanho é variável de acordo com o propósito para que foi compilado, mas, em geral, são finitos. Uma das finalidades para a construção de um corpus é que ele seja representativo de uma variedade linguística ou de uma língua (Baker, 2010; McEnery \& Wilson, 2001), por isso, quanto maior a amostra, mais evidências sobre a língua se pode obter. Alguns corpora são construídos com o intuito de serem constantemente aumentados, à medida em que novos textos são produzidos ou disponibilizados eletronicamente. Por maior que seja, é importante lembrar que um corpus será sempre apenas uma amostra, nunca terá a pretensão de dar conta da língua em sua totalidade, pois toda língua é, essencialmente, uma abstração, um conjunto de possibilidades / potencialidades linguísticas.

O formato eletrônico dos textos possibilita diversas formas de manipulação e pesquisa, não possíveis (ou mais morosas) quando dispomos apenas do texto impresso. É possível, inclusive, incluir outras camadas de informação ao textos, para além das palavras que o

\footnotetext{
${ }^{1}$ Santos (2008) faz uma breve discussão sobre as nomenclaturas em português, e prefere a denominação Linguística com Corpos.
} 
compõem, tarefa conhecida conhecida por "anotação linguística" (McEnery e Wilson, 2001). Anotações são informações linguísticas (sintáticas, morfológicas ou semânticas ou discursivas), associadas a cada palavra, expressão ou segmento de texto, tal como etiquetas, que possibilitam diversos tipos de buscas ou análises utilizando ferramentas comutacionais. Ao conjunto de etiquetas existentes em um corpus anotado, dá-se o nome de tagset, que é definido para servir a determinado propósito, ou seja, de acordo com o que se pretende pesquisar. As anotações podem ser feitas de modo automático por programas criados especificamente para esse fim, corrigidas ou não por pessoas, ou manualmente, por apenas uma pessoa ou um grupo de pessoas (McEnery e Wilson, 2001). A adição automática de etiquetas morfossintáticas às palavras de um corpus é feita por um software conhecido como parser, ou analisador sintático. A anotação semântica também pode ser feita de forma automática ou a partir de regras manualmente inseridas, que podem ser depreendidas ou incluídas, por exemplo, a partir de listas de palavras como dicionários, glossários, thesauri e ontologias. São muito usados também programas de anotação automática que "aprendem" sozinhos, a partir dos dados por aprendizado de máquina, fazendo generalizações a partir de padrões identificados no corpus, para os dois tipos de anotação.

McEnery \& Wilson (2001) ressaltam que é importante que o usuário do corpus tenha consciência de que a anotação linguística pode conter falhas e que "um ato de anotação é por definição também um ato de interpretação, tanto da estrutura, quanto do seu conteúdo" (trad. nossa). Todo corpus, anotado ou não, inclui também metadados, que são os dados considerados relevantes pelos seus criadores, acerca de cada um dos textos, tais como nome e gênero do autor, ano de publicação ou período (literário, histórico) em que foi escrito, região, variedade linguística, entre outros. Os metadados ajudam o usuário a identificar a origem e o assunto do texto e também servem como meio de filtragem de informações numa busca. Todos os dados e escolhas feitas durante um 
trabalho de compilação de corpus devem ser documentados, e disponibilizados ao usuário.

Trabalhar com um grande corpus eletrônico não é essencial para os estudos linguísticos, mas oferece um olhar menos idealizado do que seja a língua, já que estamos lidando com textos autênticos. Alguns pesquisadores / professores escolhem usá-los para extrair exemplos naturais de fatos da língua, para elaborar um artigo ou uma aula, ou ainda para compilar dicionários, ou outras listas de palavras que, como dissemos acima, servem também para auxiliar na anotação automática de outros corpora. Outros decidem usar um corpus para observar como a língua se comporta, elaborar estudos de descrição gramatical, ou identificar padrões, que servirão para treinar ferramentas computacionais de anotação e análise linguística. É possível perceber quais são os comportamentos linguísticos mais comuns, mas olhar também para as variações e casos raros, muitas vezes não tão acessíveis através da introspecção, e tentar compreender ou sistematizar essas ocorrências. Cada corpus oferece inúmeras possibilidades de análise, por isso, e é o pesquisador quem deve avaliar qual usará. Para tal, é importante que cada corpus disponibilizado tenha uma boa documentação, que ofereça informações gerais sobre o tamanho, o conteúdo e deixe claras as decisões tomadas pelos. Em suma, o corpus mais adequado para determinado estudo sempre vai da depender do que se pretende ver.

\subsubsection{Corpus e Análise de Discurso}

Se os corpora com que trabalhamos contêm dados ocorridos naturalmente, eles também têm potencial de nos dizer algo sobre os valores da sociedade em que surgiram (Baker, 2010), portanto é possível fazer análises do discurso utilizando os métodos de estudos linguísticos com base em corpora. As repetições e padrões que sobressaem na imensa quantidade de dados podem dar revelar traços discursivos que confirmem 
ou refutem nossas intuições (Baker, 2010). Os escritos de J. R Firth, conhecido por ser um dos pioneiros nos estudos com utilização de corpus, publicados entre 1930 e 1950 demonstram que os estudos com corpus já se referiam a fenômenos semânticos como "socialmente sintomáticos" e ao potencial das análises com técnicas contextuais e sociológicas e a análises de distribuição de palavras sociologicamente importantes. (Mautner, 2009). Estas análises se aprimoraram com o avanço da tecnologia computacional e da quantidade de texto acessível, e hoje é possível fazer uma série de estudos com corpus focados nos aspectos sociais da linguagem, identificados a partir de estruturas linguísticas.

Em 2008, seis pesquisadores europeus (Baker et al., 2008) realizaram um trabalho combinando explorações em grandes corpora e Análise Crítica do Discurso (ACD). A tarefa era identificar como artigos jornalísticos ingleses construíram a imagem dos imigrantes e refugiados num corpus de 140 milhões de palavras. Os pesquisadores fizeram, primeiramente, suas análises de forma independente, valendo-se dos usuais métodos das duas distintas áreas - Baker, Gabrielatos e McEnery trabalharam com os métodos de corpus, Khosravinik, Krzyzanowski e Wodak da ACD - e, em seguida, avaliaram que benefícios cada abordagem poderia ter a partir da combinação dos métodos. Iniciaram suas análises por listas de frequências relativas e padrões lexicais estatisticamente relevantes que emergiram do corpus, complementados pela observação de suas concordâncias. Interessaram-se pelas preferências semânticas e pelas co-ocorrências, que seriam capazes de indicar a posição ideológica do autor dos textos em relação a migrantes e solicitantes de refúgio. Baker (2010) traz exemplos desse estudo e de alguns outros, para demonstrar como listas de frequência podem ser indicadores de preferência e também de marcação e como colocações (collocations) podem indicar posições ideológicas, de forma que até podem influenciar quem as ouve, tais como "imigrante" e "ilegal" que frequentemente ocorrem juntos, e essa repetição acaba reforçando a ideia de que imigrantes são indesejados, fomentando a xenofobia.

Como Baker (2010) explica, uma forma de definir algo é dizendo o que não é ou contrapô-lo a outra coisa, fazendo uma distinção binária. 
Derrida (1980 apud Baker, 2010) reconhece que há sempre uma assimetria de poder entre as duas posições, uma sempre é preferível à outra, e Cixous (1975 apud Baker, 2010) especifica que nesses dualismos uma posição é considerada a norma e a outra o desvio. Portanto, a lista de frequência ajuda a identificar em pares de palavras semanticamente relacionadas como opostas qual o termo preferencial (mais frequente); mas também pode nos ajudar a identificar traços de marcação em pares que possam identificar algum tipo discriminação, em que a expressão menos frequente é a não-marcada. Um termo como "homossexual" é mais frequentemente presente no discurso corrente do que "heterossexual" - Baker (2010) demonstra com dados extraídos de corpora, tal como fizemos nesta pequisa.

Há um tipo de trabalho conhecido como análise de "conteúdo", definido por Bardin (1977, apud Freitas, Biar e Martins, no prelo) como uma técnica para obtenção de "indicadores para inferências em relação ao contexto de produção e recepção de textos", fazendo uso de "procedimentos sistemáticos, objetivos e descritivos", tais como classificação e análise da frequência de presença ou da ausência de certos itens, para ordenar um conjunto de dados textuais. Reconhecemos que há uma aproximação superficial entre a metodologia que apresentamos e a análise de conteúdo, por utilizarmos procedimentos sistemáticos e recursos computacionais, entretanto temos formas distintas de operar com tais procedimentos e tembém não acreditamos na neutralidade das tecnologias.

\footnotetext{
"Nessa visada, a dispersão bruta dos dados não é pensada como algo que deve ser arrumado em benefício da norma, mas merece por si uma perspectiva que a privilegie. A própria ideia de arrumação, aliás, é sem sentido: não buscamos "a ordem na desordem aparente" porque esta ordem não existe, mas buscamos, sim, a construção de alguma ordem (isto é, de alguma estrutura), contingente, parcial, afetada pelas lentes socioculturais de quem pesquisa, mas capaz de engendrar as análises para as questões que nos parecem pertinentes." (Freitas, Biar e Martins, no prelo)
}

Mautner (2009) lista os oito princípios da Análise Crítica do Discurso designados por Fairclough e Wodak em 1997:

1. CDA trabalha com problemas sociais.

2. Relações de poder são discursivas. 
3. O discurso constitui a sociedade e a cultura.

4. O discurso faz um trabalho ideológico.

5. O discurso é histórico.

6. O elo entre texto e sociedade é mediado.

7. A análise do discurso é interpretativa e explicativa

8. O discurso é uma forma de ação social.

Tanto a LC quanto a ACD valorizam o texto autêntico, por nele reconhecerem uma forma de materialização da linguagem. Isto não quer dizer que todos os pesquisadores que utilizam corpora em seus estudos têm a mesma visão do que é um texto ou a intenção de analisar o discurso nele presente; há quem os use para validar ou refutar teorias, ou extrair listas de palavras. Uma análise tradicional baseada em corpus não consegue identificar as razões pelas quais certos padrões são encontrados, porque não levam em consideração o contexto social, político, histórico e cultural dos dados. (Baker, 2010). Entretanto, Baker (2010) propõe que se faça "uma análise multidimensional que vá além dos elementos 'linguísticos' presentes no texto", de forma a enriquecer ainda mais o trabalho, respondendo a perguntas como:

- Quem são os autores e quão influentes são?

- Quem é a audiência desses autores?

- Quantas pessoas podem já tê-los lido e o que acharam dos textos?

- Em que contexto social, político, histórico e cultural surgiram?

- Esses textos são citados em outros textos (intertextualidade)?

- Quais são as atitudes sociais em torno dos assuntos tratados nos textos?

Entendemos que não há linguagem desvinculada de ideologia e que a linguagem constitui realidades e identidades. Acreditamos que $o$ acréscimo de uma dimensão quantitativa à análise de discurso pode ser bastante benéfica, oferecendo uma outra forma de se olhar para os dados, como já demonstraram Baker et al. (2008); Mautner (2009); Baker (2010); Cameron \& Panović (2014) entre outros. 
Uma das críticas comumente feitas aos analistas do discurso é que suas amostras são, muitas vezes, escolhidas a dedo, para se comprovar algo de acordo com uma agenda política ou ideológica (Mautner, 2009; Baker et al., 2008). A utilização de métodos estatísticos sobre um corpus reduz as possibilidades de que as análises ou amostras "seja[m] tendenciosa[s], no sentido de [inconscientemente] o analista produzir frases que dariam jeito para uma determinada teoria" (Santos, 2008), ou apenas para se comprovar algo em que se acredita. "Exteriorizar o objeto de estudo permite outras visões, outras opiniões e a comparação com outros falantes, além de nos ajudar a identificar problemas e a consciencializar-nos de aspectos que não estaríamos conscientes." (Santos, 2008). Entretanto, não nos colocamos na posição ingênua de que números e tecnologias são neutras. Todo pesquisador que tenha uma postura crítica, não importa qual método de análise use, sempre irá interpretar seus dados de acordo com suas crenças, mas é importante garantir que o universo do qual se pretende extrair os dados significativos não seja enviesado para esse fim. Como já dissemos em Freitas, Biar \& Martins (no prelo),

\footnotetext{
"não nos alinhamos com um posicionamento segundo o qual os dados emergem do corpus, fruto de tecnologias assépticas, prontos para serem analisados por um/a pesquisador/a - observador/a neutro/a ou bem treinado/a: são, antes, objetos construídos segundo a perspectiva de quem pesquisa."
}

Quanto à quantidade de palavras e textos, mais dados permitem que se encontrem mais evidências, que se percebam mais padrões significativamente ideológicos. (Cameron \& Panović, 2014). O tratamento quantitativo do corpus "possibilita a quantificação dos dados" e revela "a importância da distribuição e não apenas da concordância" (Santos, 2008) para a análise da língua e do discurso. Por outro lado, as críticas dos analistas do discurso ao trabalho quantitativo, sobretudo quando associado a análises automáticas, também é bem conhecido, justamente por comumente não considerar profundamente 0 contexto intra- $e$ extralinguístico. Aqui, é importante distinguir entre o tipo de análise que fazemos e a chamada análise de conteúdo (Bardin, 1977 apud Freitas, Biar \& Martins, no prelo), que é uma técnica utilizada obtenção de indicadores 
para inferências em relação ao contexto de produção e recepção de textos, como já mencionado em Freitas, Biar \& Martins (no prelo).

Apesar dos esforços, infelizmente, ainda há certa rejeição da parte dos analistas do discurso à análise do "macro" e aos métodos quantitativos. É importante esclarecer que a abordagem dos estudos com corpus não é puramente quantitativa. Santos (2014) acredita que a dicotomia entre qualitativo e quantitativo, tão comumente reforçada nos estudos da linguagem (e não só), "é uma falsa questão, porque é preciso atribuir qualidades para se poder contar, ou ter, pelo menos uma ideia de magnitude". Também Cameron \& Panović (2014) defendem que "uma análise qualitativa é necessária para interpretar os padrões e explicar sua significância em contexto". Este tipo de análise costuma ser rejeitada e criticada por muitos pesquisadores dos estudos da linguagem, é costume pensar que a estatística está na área das ciências exatas, que os números falam por si, sendo isentos de viés e que as ciências humanas valorizam a qualidade em detrimento da quantidade. Como também explicamos em Freitas, Biar \& Martins (no prelo):

\begin{abstract}
"Quando nos referimos a tradições qualitativas e quantitativas, estamos tratando de escolhas metodológicas. Equivocadamente, a tradição nas ciências humanas tende a associar opções quantitativas a paradigmas epistemológicos objetivistas, preocupados desvelar e medir relações entre variáveis, e, inversamente, os métodos qualitativos a práticas interpretativas situadas que localizam o/a sujeito/a que pesquisa (sua história, posições, lugares de fala) como parte constitutiva da produção do conhecimento. Essa é uma associação arbitrária."
\end{abstract}

Santos (2014) também ressalta que se podem usar "dados quantitativos para conclusões qualitativas" (e vice versa) e "como a quantificação (nas hipóteses, nos dados) é complexa e diversificada", e depende de decisões a serem tomadas cuidadosamente pelo pesquisador. Por termos o mesmo entendimento de Santos em relação à falsidade da dicotomia, já quase naturalizada, discordamos da afirmação de Moita Lopes (2013), quando, com base em Bauman (1992), diz que a análise estatística é "irrelevante para compreender o mundo social contemporâneo e sua dinâmica, fluidez e contingência, assim como para entender como tal fenômeno pode afetar o futuro". Isso depende exclusivamente do que 
pretende o pesquisador e de que decisões irá tomar em suas análises. $\mathrm{O}$ trabalho com corpus não precisa olhar apenas para o que é estatisticamente relevante; dados raros só serão descartados se o pesquisador decidir ignorar baixas ocorrências. A categorização, por exemplo, é uma forma de se dar sentido a dados raros. Uma tratamento quantitativo dos dados nos permite diversas observações possíveis. Os números, de fato, têm algo a nos mostrar, e o que é ou não relevante, depende do que se busque ver, ou dos limites que o pesquisador definir; é possível inclusive que os dados mais raros (ou únicos) emerjam com maior facilidade no corpus, ainda mais se o volume de textos for grande. Se olharmos apenas para a estrutura, ou para o que é comum, muita coisa interessante poderá ficar de fora. Na língua, as regras são tentativas de generalização de casos singulares, ou seja, abstrações, e os casos excepcionais são de fato a maioria.

Nenhum software é capaz de interpretar dados obtidos; essa função sempre será do pesquisador. "Human decision making is normally involved at almost every stage of corpus linguistics" (Baker, 2010). Um dos problemas citados por Baker, que também contribuem para o afastamento de muitos linguistas dos estudos com corpus, é que não temos treinamento apropriado para utilizar as ferramentas já existentes, e muitas vezes desconhecemos a existência delas, assim como dos corpora já existentes e disponibilizados. Cada pesquisador ou grupo de pesquisadores cria seus próprios corpora e ferramentas para dar conta do que precisam analisar, e muitas vezes essa tecnologia e os dados ficam apenas disponíveis localmente. O ponto que ele enfatiza é que o importante é disponibilizar as ferramentas e os estudos para permitir que as pessoas mudem seus pontos de vista, seu comportamento, criticando a atitude de quem faz pesquisa apenas com o intuito de publicar, e manter seu conhecimento restrito ao meio acadêmico. Há uma preocupação social com a divulgação dos métodos, resultados e ferramentas.

Acreditamos, portanto, que as análises com corpus podem oferecer uma possibilidade ao analista do discurso de observar seus dados de uma 
perspectiva diferente, aprimorando suas análises, tal como Baker (2010). O trabalho de Baker et al. (2008) já mostrou as vantagens oferecidas por essa sinergia metodológica, mesmo que realizado com base em um corpus não anotado, lidando apenas com quantificações e co-ocorrências, o que faz com que as pequenas quantidades se diluam nos resultados e não sejam observáveis. Quando lidamos com anotação, estamos lidando com classes, e não com instâncias, Isto permite observar inclusive ocorrências pouco frequentes, e isto permite explorações de outra natureza.

\subsubsection{Leitura não-linear}

Em 2005, Moretti publicou uma obra sobre um tipo de leitura que o autor chama de "distanciada", feita sobre os dados estatísticos extraídos de obras literárias. Este tipo de leitura só é possível graças à imaterializade do texto em formato digital, conforme observa Freitas (2017). Freitas (2017) explica que o texto "descoporificado" 2 é um dos elementos que possibilita termos hoje as Humanidades Digitais, e este formato oferece ao pesquisador uma lente computacional para se analisar os dados/acervos disponíveis em formato eletrônico. O que vemos, na verdade é uma interface gráfica, "mas que não está na tela" como "está em um livro ou revista" [...] "O que lemos na tela é um simulacro de texto" (Freitas, 2017), que aparenta semelhança com o formato impresso, mas que é "um aglomerado de codificações". Por outro lado,

"[Large corpora] are semiotically impoverished, reduced to text-only format without any information on accompanying visuals, layout, typography, gesture, facial expression and intonation, all of course can contribute crucially to the creation of meaning. These limitations do not make corpora useless for CDA applications, but they might go some way towards explaining why critical discourse analysts have not been quite as enthusiastic about reaching corpus linguistics as they might be." (Mautner, 2009)

É impossível negar que, numa análise de listas de distribuição, perdemos a dimensão contextual da linguagem, mas há meio de se

2 O termo "descorporificação" foi tomado de Paixão de Sousa (2013) 
recuperá-la, ainda que não em sua totalidade. Podemos, por exemplo, levar em consideração quem são os autores dos textos, para quem escrevem, sobre o que ou quem escrevem (dados extralinguísticos valorizados pela $A C D$ ) para interpretar as escolhas lexicais que aparecem nas listas de distribuição. Sempre que percebemos algum dado interessante, é possível aproximar o olhar e identificar em que contexto ele ocorre. É ainda possível cruzar dados das obras com dados das críticas e comentários sobre as mesmas.

\subsection{Extração de informações e mineração de dados textuais}

Vivemos numa época em que as pessoas estão produzindo e disponibilizando cada vez mais dados em meios eletrônicos, mas ainda estamos descobrindo como trabalhar com eles. Dentre as tarefas mais comuns da Linguística Computacional/PLN estão a mineração de textos e a extração automática de informação, utilizadas para, por exemplo, descobrir como os clientes se sentem em relação a um produto, ou notícia - trabalho conhecido como análise de sentimentos. Para muitos, os dois nomes - Extracao de Informação e Mineração de textos - designam a mesma tarefa; Hearst $(2003,1999)$, reconhece, de uma forma purista, uma diferença entre ambas. A extração de informação para Hearst envolve a detecção de padrões a partir do que está explícito nos textos. Mineração de textos (ou de dados textuais) é a descoberta de informações até então desconhecidas, não explícitas, a partir do que está dado no texto: something that no one yet knows and so could not have yet written down. (Hearst, 2003).

\footnotetext{
"There are programs that can, with reasonable accuracy, extract information from text with somewhat regularized structure. For example, programs that read in resumes and extract out people's names, addresses, job skills, and so on, can get accuracies in the high 80 percent. I don't consider this to be text mining; rather it falls into an area called information extraction. However, I am a bit of a purist when it comes to defining what text mining is. I distinguish between what I call "real" text mining, that discovers new pieces of knowledge, from approaches that find overall trends in textual data." (Hearst, 2003, grifo nosso)
} 
Para fins de análise de discurso, pode parecer ser inútil trabalhar com listas de palavras, desconsiderando o contexto em que foram proferidas, mas já vimos que os métodos de extração de informação (ou de mineração de dados textuais) nos dão os meios iniciais para a análise, que se complementam com a observação das linhas de concordância, que auxiliam o analista a inferir elementos contextuais de modo a recriar 0 contexto. (Baker et al., 2008). E se utilizarmos a leitura não-linear, podemos sempre aproximar um pouco mais o olhar quando necessário, até mesmo do texto integral. Vale lembrar que este trabalho tenta uma aproximação entre a análise de discurso e os estudos linguísticos com base em corpus. Para extrairmos nossos dados, não buscamos por termos específicos, mas por termos pertencentes a uma determinada categoria de palavras, a partir da identificação de padrões da língua, graças à anotação do corpus, seguindo o método Hearst. Em seu artigo de 1992, Hearst detalha os passos de sua pesquisa para extração de relações hiponímicas a partir de um corpus. A pesquisadora efetuou buscas a partir de estruturas sintáticas indicativas de tais relações. Os padrões identificados por Hearst foram:

- $\quad \mathrm{NP}^{3}$ such as $\{\mathrm{NP},\}^{*}$ for $\mid$ and $\} \mathrm{NP}$

(S1) The bow lute, such as the Bambara ndang ...

- $\quad$ such NP as $\{N P,\}^{*}$ for $\mid$ and $\}$ NP

(S2) ... works by such authors as Herrick, Goldsmith, and Shakespeare.

- $\quad \mathrm{NP}\{, \mathrm{NP}\}^{*}\{$,$\} or other NP$

(S3) ... bruises, wounds, broken bones or other injuries ...

- $\quad \mathrm{NP}\{, \mathrm{NP}\}^{*}\{$,$\} and other NP$

(S4) ... temples, treasuries, and other important civic buildings.

- $\quad \mathrm{NP}\{$,$\} including \{N P$,$\} *$ or $\mid$ and $\}$ NP

(S5) All common-law countries, including Canada and England ...

- NP $\{$,$\} especially \{N P$,$\} *$ \{or | and $\}$ NP

(S6) ... most European countries, especially France, England and Spain.

Obviamente, estas estruturas não dão conta da totalidade de padrões presentes na língua para identificação de relações hiponímicas, mas de

${ }^{3} \mathrm{NP}=$ noun phrase. Em português, sintagma nominal. 
uma parte significativa e representativa. Os padrões da língua que conhecemos enquanto falantes e linguistas nos ajudam a extrair as informações desejadas de um corpus, utilizando expressões de busca que recriem cenários sintáticos. As expressões utilizadas na presente pesquisa serão detalhadamente apresentadas no capítulo 3.

\subsection{Algumas palavras sobre gênero}

\subsubsection{Definições e teorias}

Gênero é uma palavra polissêmica. Segundo definição do dicionário Aulete Digital ${ }^{4}$, gênero é:

1. Conceito que engloba todos os grupos com características básicas comuns (espécies) num universo ou classe de seres ou coisas

2. P.ext. Conjunto de seres ou coisas que têm a mesma origem ou que se encontram ligados pela semelhança de suas principais características: o gênero humano.

3. Espécie, tipo: Ele gosta de todo o gênero de pessoas.

4. Biol. Categoria taxonômica de animais ou vegetais que se situa abaixo de família e acima de espécie

5. Gram. Categoria gramatical que classifica nomes e pronomes de uma língua, distinguindo-os, p.ex., entre masculino, feminino e neutro

6. Liter. Categoria distintiva de composição literária: $O$ romance é um gênero literário; a poesia, outro.

7. Art.PI. Cin. Natureza do assunto tratado por um artista: filme do gênero romântico.

44 http://www.aulete.com.br/gênero - acesso em 2/2/2020 
8. Antr. A forma que a diferença sexual assume, nas diversas sociedades e culturas, e que determina os papéis e o status atribuídos a homens e mulheres e a identidade sexual das pessoas.

9. Ret. Divisão dos discursos conforme os fins a que se propõem e os meios que empregam para tal.

Neste trabalho, utilizamos o termo para nos referirmos tanto ao sentido antropológico, quanto ao gramatical dados pelo dicionário, e também nos alinhamos com a definição dada por Butler (2019), que define gênero como "os significados culturais assumidos pelo corpo sexuado" e por Beauvoir (1949), para quem o gênero é construído e assumido pelo indivíduo. Partimos de um uma perspectiva binária de gênero, apenas por uma escolha metodológica, visto que os textos que compõem nosso corpus partem desse pressuposto socialmente, e entendemos que "homem" e "mulher" são, no fundo, categorias. Categorias são forma de organização mental e linguística do mundo que nos cerca. De acordo com Lakoff (1990), "sem a capacidade de categorização não funcionaríamos, nem no mundo físico, nem em nossas vidas social e intelectual. [... É] parte do que nos torna humanos" (trad. nossa). A maior parte das categorizações acontece, segundo o linguista, de forma "automática e inconsciente, e só tomamos consciência do processo quando nos deparamos com casos problemáticos".

Simone de Beauvoir (1949) também identifica o "ser mulher" como uma categoria, quando pontua que que ser fêmea basta para alguém ser considerada uma mulher. Há uma série de expectativas sociais - uma suposta feminilidade que estaria em perigo em seu tempo - como certas características físicas (aparência) e comportamentais - estereótipos, discursivamente construídos e internalizados como valores naturalmente esperados de quem seja mulher. Na mesma linha, Butler (2019) propõe que o gênero é performativo, uma forma de se apresentar no mundo, um traço identitário. Homens e mulheres, cis ou trans, apresentam-se ao mundo de determinada forma que os faça serem reconhecidos como pertencentes a um ou outro gênero. Quanto mais distanciado o olhar, mais simples e natural parece a atividade categorização. Conforme vamos nos 
aproximando dos indíviduos, observamos mais detalhes, vamos tomando consciência de casos menos óbvios, em que temos dificuldade de encaixar alguém nesta ou naquela categoria, e isto demonstra que categorização binária acaba não sendo o suficiente diante da complexidade humana, levando-nos e criar outras categorias de gênero; ou ainda perceber que as categorias de gênero inevitavelmente se interseccionam com outras categorias identitárias. ${ }^{5}$

Retornando a Lakoff (1990), a categorização é uma atividade humana muito básica, que utilizamos a todo momento - sempre que citamos "tipos" de coisas, agrupando-as de acordo com alguma propriedade em comum - embora, enquanto cientista cognitivo, ressalte que esta seja apenas uma parte da história ${ }^{6}$. Toda categorização é, portanto, arbitrária: anulamos as diferenças dos objetos / sujeitos de forma a "igualar não-iguais" (Nietzsche, 1911).

\subsubsection{Representatividade nas artes}

Cameron (2012) relata um fato curioso que aconteceu em 1875, quando o imperador do Japão decidiu que as meninas deveriam frequentar uma escola cuja educação era voltada para o cuidado do lar e da família. Os escritores populares na época criaram um personagem em seus livros - a "menina da escola" (school girl) - que utilizava certas partículas vocabulares estigmatizadoras, inexistentes na fala real. Mas a jovem estudante, de comportamento exemplar, não falava dessa forma. Essas personagens caricatas foram uma tentativa de se incentivar as meninas a seguirem os bons exemplos. Entretanto, percebeu-se um efeito contrário entre as jovens da época: por considerarem as meninas rebeldes das

\footnotetext{
${ }^{5}$ Citando Butler, "o gênero nem sempre se constituiu de maneira coerente ou consistente nos diferentes contextos históricos, e porque o gênero estabelece interseções com modalidades raciais, classistas, étnicas, sexuais e regionais de identidades discursivamente construídas."

${ }^{6}$ Lakoff (1990) é uma obra totalmente dedicada ao estudo cognitivo da linguagem a partir da categorização.
} 
histórias mais interessantes, as jovens na vida real passaram a adotar na sua fala os tais hábitos criados para caracterizar as meninas frívolas e vulgares. Citamos este exemplo para justificar nosso entendimento de que a literatura (re)produz o comportamento social e reflete a ideologia de quem a escreve. Citando Fabrício (2006), “nossas práticas sociais não são neutras, e envolvem escolhas (intencionais ou não) ideológicas e políticas, atravessadas por relações de poder, que provocam diferentes efeitos no mundo social".

Em artigo de 1973, Laura Mulvey realiza um estudo com base psicanalítica para compreender o prazer visual do cinema sobre a mulher. Sendo a maioria dos diretores do sexo masculino, a mulher na tela desempenha um papel tradicional exibicionista, aparece na condição de para-ser-olhada. Citando Budd Boetticher (apud Mulvey):

"O que importa é o que a heroína provoca, ou melhor, o que ela representa. É ela que, ou melhor, é o amor ou o medo que ela desperta no herói, ou então a preocupação que ele sente por ela, que o faz agir dessa maneira. Em si mesma, a mulher não tem a menor importância".

Este pensamento está alinhado ao de Beauvoir (1949), que diz que "A humanidade é masculina, e o homem define a mulher não em si, mas relativamente a ele; não é considerada um ser autônomo." Mulvey percebe a agentividade do homem nos filmes, "no sentido de fazer avançar a história, deflagrando os acontecimentos". Quanto à objetificação e glamourização do corpo feminino nas cenas dos filmes analisados, avalia que "as características glamourosas de um astro masculino não são as mesmas do objeto erótico do olhar, e sim aquelas pertencentes ao mais perfeito, mais completo, mais poderoso ego ideal concebido no momento original de reconhecimento frente ao espelho."

O Teste de Bechdel foi criado para avaliar se há um bom aproveitamento de personagens femininas em uma história, ao questionar se há ao menos duas mulheres com nomes, que conversem entre si sobre algum assunto que não seja um homem. Sobre a subrepresentação das mulheres em obras de ficção, Virginia Woolf (1929) reflete, num trecho de "Um teto todo seu": 
"Todas essas relações entre mulheres, pensei, recordando rapidamente a esplêndida galeria de personagens femininas, são simples demais. Muita coisa foi deixada de fora, sem ser experimentada. E tentei recordar-me de algum caso, no curso de minha leitura, em que duas mulheres fossem representadas como amigas. [...] Vez por outra, são mães e filhas. Mas, quase sem exceção, elas são mostradas em suas relações com os homens. Era estranho pensar que todas as grandes mulheres da ficção, até a época de Jane Austen, eram não apenas vistas pelo outro sexo, como também vistas somente em relação ao outro sexo. E que parcela mínima da vida de uma mulher é isso!"

O Geena Davis Institute on Gender in Media é uma organização que trabalha colaborativamente com a indústria do entretenimento para ajudar a conseguir equilibrio nas representações de gênero e a reduzir os estereótipos prejudiciais na caracterização das personagens. Por acreditar que $o$ que se vê nas telas do cinema influencia diretamente os expectadores, estimula roteiros em que mulheres não apareçam apenas nas funções de mãe e esposa, por exemplo. Uma forma de medir a representatividade feminina em obras de ficção é o teste de Bechdel, que questiona se a obra tem ao menos duas personagens femininas que falem entre si sobre um assunto que não seja um homem. Segundo pesquisa do instituto (Smith et al., 2014), realizada com base em roteiros de 120 filmes produzidos em 11 países, lançados entre 2010 e 2013, que as mulheres continuam sendo estereotipadas e sexualizadas nas telas, sendo representadas em papeis lugares sociais de pouca importância. A maioria das personagens nomeadas nas telas é masculina (69\% dos 5799 personagens). Os filmes brasileiros avaliados apresentam $37.1 \%$ de personagens femininas com alguma fala, estando em segundo lugar na escala de representatividade feminina. No que se refere aos papeis protagonistas, apenas $23 \%$ são de mulheres.

A presença de personagens femininas nos filmes também aumenta de acordo com quem os escreve ou realiza e também de acordo com o gênero dos filmes. De todos os filmes avaliados, apenas $20 \%$ foram dirigidos, produzidos ou escritos por mulheres, enquanto no Brasil, $33 \%$ dos roteiros foram escritos e $47 \%$ produzidos por mulheres, o campeão no ranking, considerado o mais equilibrado entre os gêneros na parte de execução. Apesar disso, nenhum país representou as mulheres e os homens em uma proporção equilibrada; somente 3 filmes apresentavam 
mais personagens femininas do que masculinas. Personagens femininas são majoritariamente (57\%) representadas em idade adulta (21-39 anos) e apenas $19 \%$ das mulheres nas telas estão entre os 40 e os 64 anos, abrindo espaço para a sexualização da mulher. A maioria dos homens também é representada nessa faixa etária $(48 \%)$, mas $34 \%$ são retratados como homens de meia idade (40-64 anos). A representação nas telas de corpos magros e sexualizados pode também influenciar os espectadores, reforçando expectativas e estereótipos de beleza, podendo também agravar distúrbios de ansiedade em relação à aparência. A pesquisa conclui que as personagens femininas nas telas têm 5 vezes mais chances do que masculinas de receberem comentários baseados na aparência. Diante destes dados, é evidente a relevância desse tipo de pesquisa no reconhecimento da importância da representatividade nas telas e a influência que a mídia tem na criação e manutenção de vieses e estereótipos.

\subsubsection{Viés de gênero na linguagem}

Sendo a humanidade "essencialmente masculina" (Beauvoir, 1949), se pensarmos na organização social da maioria dos povos, em que os homens são majoritariamente os detentores do poder - a própria língua que falamos reflete as consequências dessa assimetria, do discurso hegemônico patriarcal. Câmara Jr. (1970), ainda em relação ao gênero gramatical dos substantivos em geral, do ponto de vista semântico, diz que "o masculino é uma forma geral, não-marcada, e o feminino indica uma especialização qualquer." Já Azeredo (2008), em relação à marcação morfológica, diz que uma forma não é marcada por si, mas sempre em relação a outra. Câmara Jr. percebe a diferença entre gênero e sexo, e entende que é comum a confusão entre ambos: "o gênero abrange todos os nomes substantivos portugueses, quer se refiram a animais, providos de sexo, quer designem apenas "coisas" [...]"

Deutscher (2010) defende que "os gêneros gramaticais podem influenciar as percepções dos falantes quanto aos objetos que o cercam", 
e relata alguns experimentos feitos nos anos 90, que demonstram que os falantes de línguas que dividem objetos inanimados entre femininos e masculinos tendem a identificar características atribuídas a homens e mulheres, geralmente estereotipados, em objetos inanimados, de acordo com o gênero gramatical dos substantivos que os nomeiam. Num dos testes, realizado por Broditsky \& Schmidt, em 2003, o autor destaca o caso de "ponte" em que "falantes de alemão [gen. fem.: die Brücke] tiveram uma tendência a descrever pontes como belas, elegantes, frágeis, pacíficas, bonitas, e esbeltas; falantes de espanhol [gen. masc.: el puente] como grandes, perigosas, longas, fortes, robustas e imponentes" (Deutscher, 2010, trad. nossa). Em outro, desenvolvido por Sera et al., no mesmo ano, ao serem solicitados a dublar um desenho animado de um garfo, espanhóis, tendiam a atribuir uma voz masculina (gen. masc.: el tenedor) e os franceses uma voz feminina (gen. fem.: la fourchette).

Através da linguagem, as ideias concebidas culturalmente do que é ser mulher ou ser homem são naturalizadas e reproduzidas. "E, como tais hábitos de fala são cultivados desde a mais tenra idade, é esperado que eles se tornem hábitos da mente além da linguagem em si, afetando experiências, percepções, associações, sentimentos, memórias e orientação no mundo." (Deutscher, 2010). 


\section{Metodologia}

Neste capítulo, iremos mostrar como fizemos a escolha de um corpus adequado para este tipo de estudo, e como foram feitas as buscas. A metodologia que desenvolvemos para identificar os termos utilizados na caracterização de seres humanos envolve as seguintes etapas:

1- Busca por padrões: que estruturas linguísticas do português são indicadoras de predicação e de ação, referentes a personagens do discurso, separadas por gênero?

2- Obtenção de listas de frequência: quantas vezes aparece cada uma das predicações / ações obtidas para cada um dos gêneros?

3- Análise dos dados brutos: possibilidade de identificação de erros e também de outros padrões, até então não pensados.

4- Categorização das ocorrências: é possível categorizar os predicadores e os verbos obtidos?

5- Validação das categorias: através de testes, identificar se as categorias pensadas fazem sentido para outras pessoas.

6- Análise dos resultados das listas de frequência e categorização.

\subsection{A escolha do corpus}

Como já dissemos no capítulo anterior, a escolha do corpus adequado para um determinado estudo sempre depende do que se pretende ver, portanto precisávamos escolher um que possibilitasse contrastar caracterizações de homens e mulheres e as ações que executam. A literatura em prosa nos pareceu uma ótima fonte, especialmente por seu forte aspecto descritivo e riqueza de personagens. Ainda que se possa argumentar que no caso de personagens literários não sejam pessoas reais sendo retratadas, as personagens são "seres puramente intencionais [...] totalmente projetados por orações", criadas com bastante riqueza de detalhes de modo a garantir a verossimilhança, que faz com que o leitor consiga entrar no jogo do faz-de-conta (Cândido, 
1964). Na Linguística e na Filologia, a literatura foi, durante algum tempo, bastante utilizada como amostra da norma padrão, ou da "boa escrita"; mas, além de fornecer informações sobre a língua, ela pode também dizer muito dos valores e costumes da nossa sociedade, enquanto forma de expressão cultural, e foi esse aspecto o principal motivador de nossa escolha.

Elegemos o corpus OBras (Santos, Freitas \& Bick., 2018), que compreende um acervo de obras da literatura brasileira em domínio público. Trata-se de um corpus dinâmico, isto é, em constante expansão, e a versão com que trabalhamos contém 248 obras (no momento da escrita desta dissertação, o OBras já está na versão 8.9, que contém 252 obras). Este corpus integra o acervo do $\mathrm{AC} / \mathrm{DC}^{7}$, criado e mantido pela Linguateca. $\mathrm{O}$ AC/DC permite acessar, em uma única interface online de buscas, uma coleção de corpora em língua portuguesa de diversos gêneros e períodos. Permite que se façam buscas nos textos, com base em diversos critérios, tais como gênero textual, estilos de época, gênero (masculino ou feminino) do autor, período em que foi produzido, a fonte do texto, e aspectos especificamente linguísticos, como tempo verbal ou pessoa do discurso, função sintática, gênero e número morfológico e categoria gramatical, graças às etiquetas morfossintáticas, adicionadas automaticamente pelo analisador sintático PALAVRAS (Bick, 2000), às anotações semânticas, inseridas com base em estudos de diversos colaboradores do projeto, e também à riqueza dos metadados incluídos em cada documento. Todo o material é público, pode ser acessado sem necessidade de cadastro e contém atualmente mais de um bilhão de palavras. O corpus OBras também é parte integrante da Gramateca e da Literateca, projetos da Linguateca para estudos gramaticais e literários, respectivamente, possíveis graças à estrutura do AC/DC.

A assimetria entre os gêneros masculino e feminino é perceptível na própria composição do corpus, pois há apenas três obras de autoria feminina, de duas autoras: Maria Firmina dos Reis e Júlia Lopes de Almeida. Podemos dizer que há dois fatores essenciais para esta

\footnotetext{
${ }^{7}$ Página do projeto: https://www.linguateca.pt/ACDC/
} 
desproporção (no Apêndice 8 listamos todas as obras/autores que constam da versão do OBras com que trabalhamos). O primeiro diz respeito ao lugar social da mulher até o século XX. Woolf (1929) propõe que a condição social da mulher inglesa no século XIX teria a impedido de dedicar-se à escrita. Nessa mesma época, e até mesmo durante as primeiras décadas do século $X X$, também a mulher brasileira permanecia silenciada pelos costumes sociais e pelo analfabetismo, como já explicamos. $O$ segundo fator deve-se à dificuldade que temos de acessar obras em domínio público em formato de texto digital acessível. A Biblioteca Nacional disponibiliza obras em formato fac-símile com acessibilidade textual propiciada pela tecnologia OCR (optical character recognition), mas pouquíssimas de autoria feminina. Em alguns casos, a obra aparece como imagem, que, quando passada para texto (OCR) ainda requer um tratamento adicional para limpeza dos erros de conversão.

\subsection{Identificação das personagens}

A procura no AC/DC requer um conhecimento de como o programa "entende" o que queremos perguntar, ou sua "sintaxe". A Linguateca oferece as instruções, e isso requer alguma leitura e treino. Uma vez compreendido como funciona a sintaxe básica da ferramenta, é necessário pensar sobre o que perguntar e como. Da mesma forma que Hearst (1992)

pensou em padrões léxico-sintáticos indicativos de relações de hiperonímia, foi necessário pensar sobre os padrões que poderiam indicar a presença de predicação ou ação de personagens. Neste tipo de estudo, que não busca por termos específicos, mas por termos pertencentes a uma determinada categoria de palavras, a anotação morfossintática é uma enorme vantagem.

Em Freitas, Biar \& Martins (no prelo), damos um primeiro passo na exploração de padrões indicadores de predicações humanas. Aqui, aperfeiçoamos os procedimentos. Primeiramente, já que esperávamos identificar a diferenciação por gênero lexical, foi necessário pensar como seria possível identificar as personagens, isto é, pessoas, no corpus, e se 
seria possível identificar o seu gênero. Após alguma reflexão, valendo-nos da camada extra de informação que a anotação do corpus oferece, chegamos a quatro possibilidades de indicadores:

a) Nomes próprios humanos:

$$
\text { [pos="PROP."hum"] }{ }^{8} \text { ou [sema="Pessoa"] }
$$

b) Pronomes pessoais de terceira pessoa:

$$
\text { [lema="ele|ela"] }
$$

c) Nomes comuns que designam de grau de parentesco:

[sema="parentesco"]

d) Substantivo comum indicador de pessoa, segundo o gênero:

[lema="mulher|rapariga|moça|menina|senhora"]

[lema="homem|rapaz|moço|menino|senhor"].

Claramente, esta estratégia é limitada, e deixamos de fora uma série de outras maneiras de indicar pessoas, mas surge como um bom começo. Por outro lado, nomes próprios nem sempre são óbvios quanto ao gênero da pessoa que nomeiam. A partir de listas de nomes obtidas por cada possível etiqueta de gênero no corpus [gen="M|F|M/F"] fizemos uma análise para ver quais nomes estavam claramente anotados com o gênero errado (por exemplo, "Luís=de=Camões", "D.=Lucrécia", "Salomé", "Marcela") e quais poderiam estar errados dependendo do contexto (por exemplo, "Paula=Brito", "Missé", "Salema”, "Pávia"). Estes últimos foram confirmados nas linhas de concordância. No total, foram propostas as correções dos gêneros de 831 nomes próprios e a atribuição da etiqueta semântica "Pessoa" a todos os nomes próprios que confirmamos serem referentes a personagens humanos. Aproveitamos ainda para sugerir a correção de algumas anotações de classes de palavras e de erros de segmentação do texto, e com isso já apresentamos uma contribuição do presente trabalho. Após as alterações terem sido concluídas pela Linguateca, pudemos prosseguir com as buscas, abrindo mão da procura

\footnotetext{
${ }^{8}$ Considerada inicialmente como uma possibilidade, mas posteriormente desconsiderada, como será dito mais à frente.

${ }^{9}$ Esta foi a forma de busca utilizada para os resultados da dissertação. Atualmente, a anotação semântica do grau de parentesco foi melhorada, e a expressão equivalente ao que pedimos seria [pos="N" \& sema=".*família."”]
} 
por nomes próprios humanos [sema="PROP.*hum"], para utilizar apenas a etiqueta semântica "Pessoa"10.

\subsection{Desenvolvimento de expressões de busca por relações de predicação}

O passo seguinte foi pensar como seria possível identificar os predicadores que caracterizavam esses nomes / pronomes. Seguimos o método Hearst (Hearst, 1992) para a criação de expressões de busca a partir de padrões léxico-sintáticos que indicassem as relações desejadas. Realizamos vários testes no AC/DC, adaptando as expressões até que trouxessem o maior número de ocorrências e menor número de erros sempre confirmados nas linhas de concordância -, porque certos contextos sintáticos pensados não levam apenas a estruturas de predicação. As expressões finais seguem descritas a seguir, acompanhadas de um exemplo obtido do corpus. Tanto nas descrições das expressões, quanto nos exemplos, destaca-se, em negrito, o predicador que se obtém.

\section{Predicativos do sujeito:}

\section{a. Nomes próprios marcados com a etiqueta semântica "Pessoa"}

i. verbo ser ou estar + (advérbio) ${ }^{* 11}$ [predicação]

Feminino:

([sema="..Pessoa. *" \& gen="F" \& func="SUBJ>"] [lema="ser|estar"] [pos="ADV."]* @[temcagr!="."PASS.*" \& pos="ADJ|N|V" \& func="<SC"])

id="O_seminarista Prosa:romance BG 1872 romantismo_regionalismo masc ": Margarida estava deslumbrante de formosura. ${ }^{12}$

\footnotetext{
10 Especificamente, usamos a expressão [sema=". *Pessoa. *"]

$11 \mathrm{O}$ asterisco nas expressões tem a função de informar à ferramenta que pode-se ter ou não o item indicado, ou seja, que pode ter ou não um advérbio diante do predicador. Isto possibilita aumentar os cenários sintáticos, e , consequentemente, o número de predicadores obtidos.

${ }^{12}$ Em cada exemplo extraído das linhas de concordância, aparecem também metadados (dados das obras), que oferecem mais uma camada de contexto ao trecho selecionado.
} 
Masculino:

([sema=".*Pessoa. *" \& gen="M" \& func="SUBJ>"] [lema="ser|estar"]

[pos="ADV.*"]* @[temcagr!=".PASS.*" \& pos="ADJ|N|V" \& func="<SC"])

$i d=" O \_C o r t i c ̧ o$ Prosa:romance AA 1890 naturalismo masc ": Henrique era

bonitinho, cheio de acanhamentos, com umas delicadezas de menina.

ii. verbo ser ou estar + (advérbio)* [predicação] e
[predicação]

Feminino:

([sema="..Pessoa. *" \& gen="F" \& func="SUBJ>"] [lema="ser|estar"] [pos="ADV.*"]* [pos="ADJ.*" \& gen="F" \& func!=">N"] "e" @[pos="ADJ.*" \& func!=">N"])

id="Casada_e_viúva Prosa:conto MdA 1864 masc ": Cristiana estava confusa e trêmula.

Masculino:

([sema="..Pessoa. *" \& gen="M" \& func="SUBJ>"] [lema="ser|estar"] [pos="ADV. *"]* [pos="ADJ. *" \& gen="M" \& func!=">N"] "e" @[pos="ADJ. *" \& func!=">N"])

id="Miragem Prosa:romance CN 1895 realismo_naturalismo masc ": Tadeu estava deslumbrado e comovido: sorria com os olhos boiando em lágrimas.

\footnotetext{
iii. verbo ser ou estar + (advérbio)* [predicação] , [predicação]
}

\footnotetext{
Os metadados incluem o nome da obra, o gênero textual, a sigla que representa o nome do autor, ano de publicação, se é de autoria feminina ou masculina, escola literária, e ainda se a obra é uma tradução de obra estrangeira - neste caso, mostra também o nome do autor original, ano de publicação e gênero.
} 
Feminino:

([sema="..Pessoa. *" \& gen="F" \& func="SUBJ>"] [lema="ser|estar"] [pos="ADV.*"]* [pos="ADJ.*" \& gen="F" \& func!=">N"] "," @[pos="ADJ.*" \& func!=">N"])

id="Os_Dois_Amores Prosa:romance JMdM 1848 romantismo masc ": Emília era bela, pura, ingênua como um anjo, com seus olhos pretos, suas faces pálidas, e seu corpinho débil... pobre Emília! ...

Masculino:

([sema=".*Pessoa. *" \& gen="M" \& func="SUBJ>"] [lema="ser|estar"] [pos="ADV. *"]* [pos="ADJ.*" \& gen="M" \& func!=">N"] "," @[pos="ADJ.*" \& func! $=">N "]$ )

id="O_seminarista Prosa:romance BG 1872 romantismo_regionalismo masc ": No fim de algum tempo, Eugênio estava magro, pálido, alquebrado, que mais parecia uma múmia ambulante.

\section{b. Pronome pessoal $3^{a}$. Pessoa}

i. verbo ser ou estar (advérbio)* [predicação]

Feminino:

([lema="ela" \& func="SUBJ>"] [lema="ser|estar"] [pos="ADV.*"] @[temcagr!="."PASS. *" \& pos="ADJ|N|V" \& func="<SC"])

id="Noite_na_taverna Prosa:conto AdA 1855 masc ": Ela era ainda tão bela!

Masculino:

$\left(\left[\right.\right.$ lema="ele" \& func="SUBJ>"] [lema="ser|estar"] [pos="ADV.*"] ${ }^{*}$ @[temcagr!="."PASS. *" \& pos="ADJ|N|V" \& func="<SC"])

id="O_ermitão_do_Muquém Prosa:romance BG 1868 romantismo_regionalismo masc ": Entretanto essa voz suave, que com tanta ternura o lastima, anuncia-lhe também que ele é prisioneiro, e que 
sua vida não é poupada senão para que seja solenemente sacrificada em um dia de festins nupciais .

\section{ii. verbo ser ou estar (advérbio)* [predicação] e [predicação]}

Feminino:

([lema="ela" \& func="SUBJ>"] [lema="ser|estar"] [pos="ADV.*"] [temcagr!=".*PASS.*" \& pos="ADJ|N|V" \& gen="F" \& func="<SC"] "e" @[ pos="ADJ.*" \& func!=">N"])

id="O_Mulato Prosa:romance AA 1881 naturalismo masc ": Ela está aí fina e lampeira, que faz gosto, ao passo que a pobre da senhora D. Maria do Carmo...

Masculino:

([lema="ele" \& func="SUBJ>"] [lema="ser|estar"] [pos="ADV.*"] [temcagr!=".*PASS.*" \& pos="ADJ|N|V" \& gen="M" \& func="<SC"] "e" @[ pos="ADJ." \& func!=">N"])

id="Triste_Fim_de_Policarpo_Quaresma Prosa:romance LB 1911 realismo masc ": Ele era magro e chupado, moreno carregado e a oval do seu rosto estava amassada aqui e ali.

\section{iii. verbo ser ou estar (advérbio)* [predicação] , [predicação]}

Feminino:

([lema="ela" \& func="SUBJ>"] [lema="ser|estar"] [pos="ADV.*"] [temcagr!=".*PASS.*" \& pos="ADJ|N|V" \& gen="F" \& func="<SC"] "," @[ pos="ADJ." \& func!=">N"])

id="O_Homem_que_Sabia_Javanês_e_Outros_Contos Prosa:contos LB 1997 masc ": Calcula que ela é alta, esguia, de bom corpo; cabelos negros corridos, bem corridos: olhos pardos. 
Masculino:

([lema="ele" \& func="SUBJ>"] [lema="ser|estar"] [pos="ADV.*"] [temcagr!=".*PASS. *" \& pos="ADJ|N|V" \& gen="M" \& func="<SC"] "," @[ pos="ADJ." \& func!=">N"])

id="Clara_dos_anjos Prosa:romance LB 1948 naturalismo_realismo masc ": Todo ele era rude, metálico, grosseiro e áspero.

\section{c. Substantivo comum indicador de relação de parentesco}

i. verbo ser ou estar + (advérbio) * [predicação]

Feminino:

([sema="parentesco" \& gen="F" \& func="SUBJ>"] [word="de|do|da"] * [sema $=" P e s s o a "]^{*} \quad$ [lema="ser|estar"] [pos="ADV.*"]

@[temcagr!=".PASS.*" \& pos="ADJ|N|V" \& func="<SC"])

id="Água_de_Juventa Prosa:contos CN 1905 realismo masc ": A mãe era bonita, tinha um corpo admirável.

Masculino:

([sema="parentesco" \& gen="M" \& func="SUBJ>"] [word="de|do|da"]* [sema="Pessoa"] $\quad$ [lema="ser|estar"] [pos="ADV.*"]* @[temcagr!="."PASS. *" \& pos="ADJ|N|V" \& func="<SC"])

id="A_bico_de_pena Prosa:contos CN 1904 realismo masc ": -- Porque o marido está entrevado mas eu não estou, com a graça de Deus.

ii. verbo ser ou estar + (advérbio)* [predicação] e [predicação]

Feminino:

([sema="parentesco" \& gen="F" \& func="SUBJ>"] [word="de|do|da"] * [sema="Pessoa"] ${ }^{*}$ [lema="ser|estar"] [pos="ADV."]* [pos="ADJ." \& gen="F" \& func!=">N"] "e" @[pos="ADJ.*" \& func!=">N"]) 
id="O_seminarista Prosa:romance BG 1872 romantismo_regionalismo masc ": A mãe de Eugênio era fanática e supersticiosa.

Masculino:

([sema="parentesco" \& gen="M" \& func="SUBJ>"] [word="de|do|da"]* [sema="Pessoa"] ${ }^{*} \quad$ lema="ser|estar"] [pos="ADV.*"]* [pos="ADJ.*" \& gen="M" \& func!=">N"] "e" @[pos="ADJ." \& func!=">N"])

id="Sem_olhos Prosa:conto MdA 1876 masc ": Mas não era assim; o marido era cauteloso e suspeitoso; ameaçava-a e fazia-a padecer.

iii. verbo ser ou estar + (advérbio)* [predicação] ,
[predicação]

Feminino:

([sema="parentesco" \& gen="F" \& func="SUBJ>"] [word="de|do|da"]* [sema="Pessoa"] [lema="ser|estar"] [pos="ADV.*"]* [pos="ADJ." \& gen="F" \& func!=">N"] "," @[pos="ADJ." \& func!=">N"])

id="O_caso_da_viúva Prosa:conto MdA 1881 masc ": A prima do Rochinha estava impaciente, nervosa, desorientada;

Masculino:

([sema="parentesco" \& gen="M" \& func="SUBJ>"] [word="de|do|da"] [sema="Pessoa"] ${ }^{*} \quad$ lema="ser|estar"] [pos="ADV.*"]* [pos="ADJ." \& gen="M" \& func!=">N"] "," @[pos="ADJ."" \& func!=">N"])

id="A_falência Prosa:romance JLdA 1901 naturalismo_realismo fem ": o marido era forte, falador, arrebatado, ameaçando fazer cair a casa ao furor das suas rebentinas.

d. Substantivo comum indicador de pessoa, segundo o gênero

i. verbo ser ou estar + (advérbio) * [predicação] 
Feminino:

([lema="mulher|moça|rapariga|menina|senhora" \& func="SUBJ>"] [lema="ser|estar"] [pos="ADV.*"]* @[temcagr!=". *PASS. *" \& pos="ADJ|N|V" \& func="<SC"])

id="A_dança_dos_ossos Prosa:conto BG 1871 masc ": Estas meninas são muito boazinhas; olha como elas estão me abraçando!

Masculino:

([lema="homem|moço|rapaz|menino|senhor" \& func="SUBJ>"] [lema="ser|estar"] [pos="ADV."]* @[temcagr!=".*PASS. *" \& pos="ADJ|N|V" \& func="<SC"])

id="A_Mortalha_de_Alzira_Prosa:romance AA 1894 naturalismo_realismo_romantismo masc ": -- Em questões de amor todos os homens são igualmente estúpidos! ...

ii. verbo ser ou estar + (advérbio)* [predicação] e [predicação]

Feminino:

([lema="mulher|moça|rapariga|menina|senhora" \& func="SUBJ>"] [lema="ser|estar"] [pos="ADV. *"]* [pos="ADJ.*" \& gen="F" \& func!=">N"] "e" @[pos="ADJ.*" \& func!=">N"])

id="A_Escrava_Isaura Prosa:romance BG 1875 romantismo masc ": Casara-se por especulação, e como sua mulher era moça e bonita, sentira apenas por ela paixão, que se ceva no gozo dos prazeres sensuais, e com eles se extingue.

Masculino:

([lema="homem|moço|rapaz|menino|senhor" \& func="SUBJ>"] [lema="ser|estar"] [pos="ADV. *"]* [pos="ADJ. *" \& gen="M" \& func!=">N"] "e" @[pos="ADJ.*" \& func!=">N"]) 
id="A_falência Prosa:romance JLdA 1901 naturalismo_realismo fem ": -Como os homens são orgulhosos e injustos!

$$
\begin{aligned}
& \text { iii. verbo ser ou estar + (advérbio)* [predicação] , } \\
& \text { [predicação] }
\end{aligned}
$$

Feminino:

([lema="mulher|moça|rapariga|menina|senhora" $\quad$ \& func="SUBJ>"] [lema="ser|estar"] [pos="ADV.*"]* [pos="ADJ.*" \& gen="F" \& func!=">N"] "," @[pos="ADJ."" \& func!=">N"])

id="Grãos_de_mostarda Prosa:conto HC 1926 masc ": Minha mulher é pura, honesta, virtuosa, e não merece que eu lhe minta.

Masculino:

([lema="homem|moço|rapaz|menino|senhor" \& func="SUBJ>"] [lema="ser|estar"] [pos="ADV.""]* [pos="ADJ.*" \& gen="M" \& func!=">N"] "," @[pos="ADJ." \& func!=">N"])

id="O_moço_louro Prosa:romance JMdM 1845 romantismo masc ": Esse menino era belo, alegre e esperto, e mostrava-se, então, abatido e melancólico.

2. Apostos e predicativos de predicados verbo-nominais:

a. Nomes próprios marcados com a etiqueta semântica "Pessoa"

i. , (advérbio)* [predicação]

Feminino:

([sema=".*Pessoa. *" \& func!="P<"] "," [pos="ADV.*"] @[func="N<PRED|. *APP.*" \& gen="F" \& pos="ADJ"])

id="Banzo Prosa:contos CN 1912 realismo masc ": Sara, encolhida, rezava, não por si, mas pelos que vinham da terra, pelos que deviam vir 
sobre as vagas, no largo barco das provisões, trazendo os dias do ano novo.

Masculino:

([sema=".*Pessoa. *" \& func!="P<"] "," [pos="ADV." ${ }^{*}$

@[func="N<PRED|.*APP." \& gen="M" \& pos="ADJ"])

id="O_Mulato Prosa:romance AA 1881 naturalismo masc ": -- Não irá muito longe, disse o Freitas, sempre risonho, cansaria depressa...

ii. , (advérbio)* [predicação] e [predicação]

Feminino:

([sema=".*Pessoa. *" \& func!="P<"] "," [pos="ADV.*"]* [func="N<PRED|. *APP. *" \& gen="F" \& pos="ADJ"] "e" @[gen="F" \& pos="ADJ"])

id="O_Cortiço Prosa:romance AA 1890 naturalismo masc ": João Romão, de roupa mudada como os outros, mas sempre em mangas de camisa, aparecia de espaço em espaço, servindo os comensais; e a Bertoleza, sempre suja e tisnada, sempre sem domingo nem dia santo, lá estava ao fogão, mexendo as panelas e enchendo os pratos.

Masculino:

([sema=".*Pessoa. *" \& func!="P<"] "," [pos="ADV. *"]* [func="N<PRED|.*APP.*" \& gen="M" \& pos="ADJ"] "e" @[gen="M" \& pos="ADJ"])

id="A_Marquesa_de_Santos Prosa:romance PS 1925 histórico masc ": D. Pedro, austero e ríspido, não teve um sorriso, não teve um gesto amável. iii. , (advérbio)* [predicação] , [predicação] 
Feminino:

([sema=".*Pessoa." $\quad \& \quad$ func!="P<"] "," [pos="ADV. *"] [func="N<PRED|.*APP.*" \& gen="F" \& pos="ADJ"] "," @[gen="F" \& pos="ADJ"])

id="O_anjo_Rafael Prosa:conto MdA 1869 masc ": Pouco depois chegou Celestina, bela, descuidosa, inocente como da primeira vez; beijou a testa do pai, apertou a mão ao doutor e sentou-se no seu lugar.

Masculino:

([sema=".*Pessoa. *" \& func!="P<"] "," [pos="ADV.*"]* [func="N<PRED|.*APP.*" \& gen="M" \& pos="ADJ"] "," @[gen="M" \& pos="ADJ"])

id="Contos_fora_da_moda Prosa:conto ArtA 1894 masc ": E o senhor Rodrigues, exasperadíssimo, nervoso, deixa a sala de jantar e vai para o seu quarto, batendo violentamente a porta.

\section{b. Pronome pessoal $3^{\text {a }}$. Pessoa}

i. . (advérbio)* [predicação]

Feminino:

([lema="ela" \& func="SUBJ>"] "," $\quad$ [pos="ADV. *"] @[func="N<PRED|.*APP.*" \& gen="F" \& pos="ADJ"])

id="Novelas_Doidas Prosa:contos VirCor 1921 pré-modernismo masc ": Ela, tão pichosa outrora em vestir-se, andava agora maltrapilha, chinelos rotos, encafuada em casa, como se tivesse vergonha de sair à rua.

Masculino:

([lema="ele" \& func="SUBJ>"] "," [pos="ADV. *"]* @[func="N<PRED|. APP." \& gen="M" \& pos="ADJ"]) 
id="Água_de_Juventa Prosa:contos CN 1905 realismo masc ": Ela inclinou a cabeça sem uma queixa, submissa, vencida, apertando o lábio com os dentinhos, e ele, alucinado, beijou-a, beijou-a...

ii. , (advérbio)* [predicação] e [predicação]

Feminino:

([lema="ela" \& func="SUBJ>"] "," [pos="ADV.""] [func="N<PRED|."APP.*" \& gen="F" \& pos="ADJ"] "e" @[gen="F" \& pos="ADJ"])

id="Rapsódias Prosa:contos CN 1891 realismo masc ": Ela, mais tímida e vergonhosa, agachou-se junto de uma pedra e, embrulhada nos cabelos, pôs-se a chorar as lágrimas primeiras

Masculino:

([lema="ele" \& func="SUBJ>"] "," [pos="ADV.*"]" [func="N<PRED|. APP.*" \& gen="M" \& pos="ADJ"] "e" @[gen="M" \& pos="ADJ"])

id="Baladilhas Prosa:contos CN 1844 masc ": Cahi de joelhos e pedi-lhe que relevasse a minha audaciosa temeridade e elle, paternal e meigo, acenou para que me levantasse, indagando, com um fio de voz quasi imperceptível, que duvida me levara ao seu eremiterio.

iii. , (advérbio)* [predicação] , [predicação]

Feminino:

([lema="ela" \& func="SUBJ>"] "," [pos="ADV.*"]* [func="N<PRED|. APP. *" \& gen="F" \& pos="ADJ"] "," @[gen="F" \& pos="ADJ"])

id="Grãos_de_mostarda Prosa:conto HC 1926 masc ": Contou-lhe a sua paixão, os seus propósitos de noivado, e a ventura que esperava da vida se ela, boa, pura, honesta como era, Ihe concedesse a esperança do seu amor. 
Masculino:

([lema="ele" \& func="SUBJ>"] "," [pos="ADV. *"]* [func="N<PRED|..APP. *" \& gen="M" \& pos="ADJ"] "," @[gen="M" \& pos="ADJ"])

id="Miragem Prosa:romance CN 1895 realismo_naturalismo masc ": Ele, sozinho, arredado, meditava diante do mar sereno que vinha babar a amurada, e pelo qual o luar nascente estendia o seu clarão triste que alastrava as águas aberto em leque, como um istmo de madrepérola trêmula.

\section{Substantivo comum indicador de pessoa, segundo o gênero}

i. , (advérbio)* [predicação]

Feminino:

([lema="mulher|moça|rapariga|menina|senhora"] "," [pos="ADV.*"]* @[func="N<PRED|. APP.*" \& gen="F" \& pos="ADJ"])

id="Rapsódias Prosa:contos CN 1891 realismo masc ": Trêmula, encostada à penha, fitando o crescente que subia, a mulher, lânguida, esperava .

Masculino:

([lema="homem|moço|rapaz|menino|senhor"] [ ", [ [pos="ADV.*"] @[func="N<PRED|.*APP." \& gen="M" \& pos="ADJ"])

id="O_Coruja Prosa:romance AA 1889 realismo masc ": perguntou o rapaz, sinceramente espantado; vais partir sofrendo em silêncio o que acaba de te fazer aquele miserável ?

$$
\text { ii. , (advérbio)* [predicação] e [predicação] }
$$

Feminino:

([lema="mulher|moça|rapariga|menina|senhora"] $\quad$ "," [pos="ADV.*"]* [func="N<PRED|.*APP.*" \& gen="F" \& pos="ADJ"] "e" @[gen="F" \& pos="ADJ"]) 
id="Dona_Jucunda Prosa:conto MdA 1889 masc ": Quando acabou de ler, deu com a mulher, pálida e ansiosa.

Masculino:

([lema="homem|moço|rapaz|menino|senhor"] [ "," [pos="ADV." ]" [func="N<PRED|.APP."* \& gen="M" \& pos="ADJ"] "e" @[gen="M" \& pos="ADJ"])

id="A_Marquesa_de_Santos Prosa:romance PS 1925 histórico masc ": O homem, forte e atarracado, era Gonçalves Ledo.

iii. , (advérbio)* [predicação] , [predicação]

Feminino:

([lema="mulher|moça|rapariga|menina|senhora"] [ "," [pos="ADV.*"] [func="N<PRED|.*APP.*" \& gen="F" \& pos="ADJ"] "," @[gen="F" \& pos="ADJ"])

id="A_Carne Prosa:romance JulRib 1888 realismo masc ": Era moça, sensual, rica - gozava.

Masculino:

([lema="homem|moço|rapaz|menino|senhor"] [ "," [pos="ADV." ${ }^{*}$ [func="N<PRED|.APP.*" \& gen="M" \& pos="ADJ"] "," @[gen="M" \& pos="ADJ"])

id="O_programa Prosa:conto MdA 1882 masc ": Era um guapo rapaz, ardente, resoluto, filho de pais modestíssimos, mas cheio de alma e ambição .

3. Adjuntos adnominais:

a. Substantivo comum indicador de pessoa, segundo o gênero

i. [predicação] 
Feminino:

([lema="mulher|moça|rapariga|menina|senhora"] @[pos="N|ADJ|V" \& func $="<\mathrm{PRED}|<\mathrm{OC}| \mathrm{N}<"])$

id="O_Cortiço Prosa:romance AA 1890 naturalismo masc ": Às onze horas parou um carro à entrada do cortiço com uma senhora gorda, vestida de seda cor de pérola.

Masculino:

([lema="homem|moço|rapaz|menino|senhor"] @[pos="N|ADJ|V" \& func $="<P R E D|<O C| N<"])$

id="Muitos_anos_depois Prosa:conto MdA 1874 masc ": Era um rapaz $\underline{\text { bonito, }}$ elegantemente vestido à maneira do tempo.

ii. [predicação] e [predicação]

Feminino:

([lema="mulher|moça|rapariga|menina|senhora"] [pos="N|ADJ|V" \& func="<PRED $|<O C| N<"]$ "e" @[pos="ADJ" \& gen="F"])

id="A_Moreninha Prosa:romance JMdM 1844 romantismo masc ": Já não há mais meninas importunas e vaidosas...

Masculino:

([lema="homem|moço|rapaz|menino|senhor"] [pos="N|ADJ|V" \& func="<PRED $|<O C| N<"]$ "e" @[pos="ADJ" \& gen="M"])

id="A_Escrava_Isaura Prosa:romance BG 1875 romantismo masc ": Hão de pensar que és maltratada, que és uma escrava infeliz, vítima de senhores bárbaros e cruéis.

iii. [predicação] "," [predicação] 
Feminino:

([lema="mulher|moça|rapariga|menina|senhora"] [pos="N|ADJ|V" \& func="<PRED $|<O C| N<"]$ "," @[pos="ADJ" \& gen="F"])

$i d=" Q u i n c a s \_B o r b a$ Prosa:romance MdA 1886 realismo masc ": Uma senhora titular, cheirosa e rica, talvez demandista para matar o tédio.

Masculino:

([lema="homem|moço|rapaz|menino|senhor"] [pos="N|ADJ|V" \& func="<PRED $|<O C| N<"]$ "," @[pos="ADJ" \& gen="M"])

id="O_Mulato Prosa:romance AA 1881 naturalismo masc ": Com estes devaneios, acudia-lhe sempre um arrepiozinho de febre; ficava excitada, idealizando um homem forte, corajoso, com um bonito talento, e capaz de matar-se por ela.

\section{iv. [predicação] "," [predicação] "e" [predicação]}

Feminino:

([lema="mulher|moça|rapariga|menina|senhora"] [pos="N|ADJ|V" \& func="<PRED $|<O C| N<$ "] "," [pos="ADJ"] "e" @[pos="ADJ" \& gen="F"])

id="Noite_na_taverna Prosa:conto AdA 1855 masc ": a realidade é a febre do libertino, a taça na mão, a lascívia nos lábios, e a mulher seminua, trêmula e palpitante sobre os joelhos.

Masculino:

([lema="homem|moço|rapaz|menino|senhor"] [pos="N|ADJ|V" \& func="<PRED|<OC|N<"] "," [pos="ADJ"] "e" @[pos="ADJ" \& gen="M"]) id="O_Homem Prosa:romance AA 1887 realismo masc ": Um homem honrado, trabalhador e econômico.

v. [predicação] ", [predicação] “," [predicação] 


\section{Feminino:}

([lema="mulher|moça|rapariga|menina|senhora"] [pos="N|ADJ|V" \& func="<PRED $|<O C| N<"]$ "," [pos="ADJ"] "," @[pos="ADJ"])

id="Grãos_de_mostarda Prosa:conto HC 1926 masc ": -- Quer, então, uma rapariga forte, grande, morena?

\section{Masculino:}

([lema="homem|moço|rapaz|menino|senhor"] [pos="N|ADJ|V" \& func="<PRED $|<O C| N<"]$ "," [pos="ADJ"] "," @[pos="ADJ"])

id="Miragem Prosa:romance CN 1895 realismo_naturalismo masc ": E esses robustos moços alegres, ágeis, afanosos, seriam as crianças que ele havia deixado galgando montes, devastando ninhos?

\section{b. Substantivo comum indicador de relação de parentesco i. [predicação]}

Feminino:

([sema="parentesco" \& gen="F"] @[pos="N|ADJ|V" \& func $="<P R E D|<O C| N<"])$ id="Contos_fora_da_moda Prosa:conto ArtA 1894 masc ": As Guedes eram três irmãs solteironas.

Masculino:

([sema="parentesco" \& gen="M"] @ @[pos="N|ADJ|V" ～\& func=" $<$ PRED $|<\mathrm{OC}| \mathrm{N}<"]$ ) id="O_Cabeleira Prosa:romance FT 1876 realismo_regionalismo_romantismo masc ": gritou ao pé da mulher e do filho o mau marido, o pai desnaturado, carrasco da família antes de sê-lo da sociedade e de si próprio 
A busca por predicadores foi feita concatenando todas as expressões, individualmente descritas acima, em uma única grande expressão, para obtermos duas listas de ocorrências, uma para cada gênero. O Apêndice 3, ao fim deste trabalho, apresenta as expressões finais utilizadas.

\subsubsection{Resultados iniciais e criação de categorias}

Concatenando todas as expressões de busca, já excluídos os erros $^{13}$, foram obtidos 2937 predicadores masculinos, e 2325 predicadores femininos. Nos masculinos, 819 palavras diferentes (lema) e no feminino, 712. No entanto, independentemente do gênero, $83 \%$ dos predicadores apareceu até 3 vezes, $74,7 \%$ até duas vezes e 59,44\% dos predicadores apareceu apenas uma vez. Estes números são esperados, como constata a Lei de Zipf ${ }^{14}$, que diz que, numa língua, poucas palavras ocorrem muito, e um grande número de palavras ocorre apenas uma vez no discurso.

Isto significa que, se fôssemos analisar apenas as predicações mais frequentes, a grande maioria dos predicadores encontrados não seria considerada. É preciso olhar para ocorrências mais frequentes, porque são as mais comuns, mas nos interessa igualmente olhar para a longa lista de predicadores que aparece menos vezes, pois que, de fato, são a maioria. A solução pensada para trabalhar esses dados foi a categorização. Sabemos que toda categorização é uma "construção interessada" (Ellis, 1993) e que propõe uma homogeneidade dos dados, abrindo mão das diferenças entre eles, e uma forma de organização básica do ser humano (Lakoff, 1990), uma atividade que nos ajuda a organizar o mundo, que facilita sua observação. A opção pela categorização nos possibilita uma

${ }^{13}$ Menos de $10 \%$ da lista de distribuição foi confirmada como erro, causado tanto por erro automático de anotação, quanto por o padrão léxico-sintático ter levado a uma estrutura não-predicativa, ou que não prediquem sobre pessoas, como "cheio", em id="A_bico_de_pena Prosa:contos CN 1904 realismo masc ": Pois vocês não estão vendo que ela está cheia de açucenas? ou "nome", em id="Valério Prosa:conto MdA 1874 masc ": O pai replicou que, se Joana era nome de velha, Rita era nome de preta.

$14 \mathrm{O}$ linguista George Kingsley Zipf fez uma contagem das palavras em Ulisses, de James Joyce, e percebeu, ao distribuí-las por uma lista de frequência, que a palavra mais comum um número excepcional de vezes, e que havia um número enorme de palavras ocorria apenas uma vez. 
outra forma de olhar para os dados em grande escala, levando em conta tanto a singularidade quanto a regularidade em nossas análises. Além disso, sempre podemos aproximar o olhar para as linhas de concordância, para o parágrafo e até mesmo o capítulo, a fim de obter o contexto.

Por isso, uma etapa fundamental do trabalho foi organizar as ocorrências em eixos semânticos. A motivação para a distribuição em eixos está detalhada em Freitas, Biar e Martins (no prelo), mas retomamos aqui os pontos principais.

Começando a observação a partir dos dez predicadores mais frequentes para caracterização de personagens obtemos:

$\begin{array}{lrlr}\text { Femininos } & \text { Qtd } & \text { Masculinos } & \text { Qtd } \\ \text { bonito } & 146 & \text { loiro } & 97 \\ \text { belo } & 68 & \text { sério } & 74 \\ \text { casado } & 58 & \text { bom } & 60 \\ \text { amado } & 46 & \text { alto } & 57 \\ \text { formoso } & 44 & \text { pobre } & 46 \\ \text { honesto } & 42 & \text { rico } & 41 \\ \text { velho } & 40 & \text { capaz } & 40 \\ \text { pálido } & 36 & \text { bonito } & 34 \\ \text { solteiro } & 34 & \text { pálido } & 32 \\ \text { bom } & 31 & \text { homem } & 31\end{array}$

Tabela 2 - Frequência dos predicadores mais comuns por gênero.

Ao verificar nas linhas de concordância o adjetivo "loiro", percebemos que há 94 ocorrências na obra "O Moço Louro", o que, sendo o tema do livro e a forma como é chamado o personagem principal, já era esperado. Por este motivo, consideramos apenas as 3 ocorrências deste adjetivo em outras obras, portanto deixa de ser o predicador masculino mais frequente no corpus. Vale salientar que filtro só é possível porque estamos trabalhando com um corpus documentado, cujos metadados permitem que se obtenha a distribuição dos resultados por obra. Apesar de se obter mais de mil predicadores a mais para homens do que para mulheres, vemos que o predicador mais usado para descrição de personagens masculinos nas obras, "sério", aparece 74 vezes, 
praticamente a metade do número de ocorrências do predicador feminino mais frequente, "bonito" (146 vezes). Podemos perceber que as mulheres são exacerbadamente caracterizadas por sua beleza (além de "bonito", vemos "belo" e "formoso" também entre os mais frequentes), enquanto os homens aparentam ser mais descritos por seu caráter ou personalidade "sério", "bom".

Seguindo a leitura de toda a lista de predicadores, conseguimos perceber quatro categorias de sentido iniciais: uma para atributos físicos, outra para estados emocionais ou afetivos, outra para relações e papeis sociais e uma quarta para traços de personalidade e caráter. Outra possível categoria, principalmente para particípios que indicam estados temporários decorrentes de uma ação, um estado temporário, como "sentado" ou "sacudido", por exemplo, que optamos por não considerar, inicialmente, em nossas análises finais (cerca de $5 \%$ do total de ocorrências obtidas). A tabela abaixo exemplifica as categorias propostas.

\begin{tabular}{|l|l|}
\hline & \multicolumn{1}{|c|}{ Predicações } \\
\hline Aparência ${ }^{15}$ & bonito; pálido; alto, gordo \\
\hline Emoção/afeto & amado, feliz; irritado, ciumento \\
\hline Lugar social & rico; casado; pai; português \\
\hline Caráter/personalidade & honesto; bom; travesso, curioso \\
\hline
\end{tabular}

Quadro 2 - Exemplos de predicadores, distribuídos por eixo semântico.

Num segundo momento, aproximamos o olhar às linhas de concordância, para entendermos o sentido em que cada predicador ocorre majoritariamente. Percebemos que, em alguns casos, os predicadores podem se encaixar em mais de uma categoria, como no caso de "perdido",

\footnotetext{
15 A princípio, demos o nome de "corpo físico" a esta categoria, e, posteriormente, julgamos mais adequado utilizar "aparência".
} 
que classificamos em caráter/personalidade e lugar social, simultaneamente, a partir de exemplos como:

(a) id="O_Matuto Prosa:romance FT 1878 realismo_regionalismo_romantismo masc ": Aquela malta de homens perdidos que, no rancho do Sipó, explorados pelo chefe, se haviam acostumado a odiar os nobres e a cobiçar os seus haveres, deparava enfim, depois de esforços e tentativas malogradas, ocasião oportuna para matar a sede de vingança e ouro que os abrasava .

(b) id="O_Coruja Prosa:romance AA 1889 realismo masc ": -- Quero provar-te que esse desprezo a que condenam a mulher perdida é nada menos do que a condenação de todas as mulheres em geral .

\subsubsection{Validação das categorias de análise}

Para validar as categorias de análise, nos inspiramos em uma prática da Linguística Computacional chamada de concordância interanotadores (inter-annotator agreement). O objetivo é verificar a confiabilidade das anotações feitas pelos anotadores (humanos). A confiabilidade depende da reprodutibilidade (isto é, da possibilidade de reprodução das análises ou classificações, por outras pessoas) e da consistência entre as anotações (Arstein, 2017). Após a distribuição dos predicadores em eixos semânticos, o passo seguinte foi a validação das categorias propostas, uma vez que toda a análise subsequente depende delas. Realizamos um teste utilizando a ferramenta Rêve ${ }^{16}$ (Santos et al., 2015), para saber se outras pessoas teriam o mesmo entendimento que nós sobre a distribuição dos predicadores pelas categorias - não para fins de concordância interanotadores, mas para validar as análises propostas

${ }^{16}$ Disponível para consulta em http://linguateca.pt/reve2/stats/36 
e, inclusive, para auxiliar em casos de difícil categorização. O Rêve é uma ferramenta da Gramateca para elaboração e realização de testes online utilizando os mesmos corpora anotados disponibilizados no AC/DC.

Dezessete voluntários participaram desse teste. Todos são falantes nativos de português, têm formação universitária, alguns, inclusive, na área linguística. As instruções dadas continham uma breve explicação e exemplos de cada categoria proposta. "Outro" e "Não sei" eram outras duas respostas possíveis. Também informava ao participante que seria possível selecionar mais de uma opção, em consonância com a possibilidade de classificação múltipla ${ }^{17}$, utilizada na distribuição das palavras em eixos. Utilizamos para o teste quarenta sentenças extraídas do corpus, com caracterizações de personagens de ambos os gêneros, incluindo exemplos que consideramos mais difíceis de classificar. O Apêndice 1 mostra todas as sentenças selecionadas para o teste.

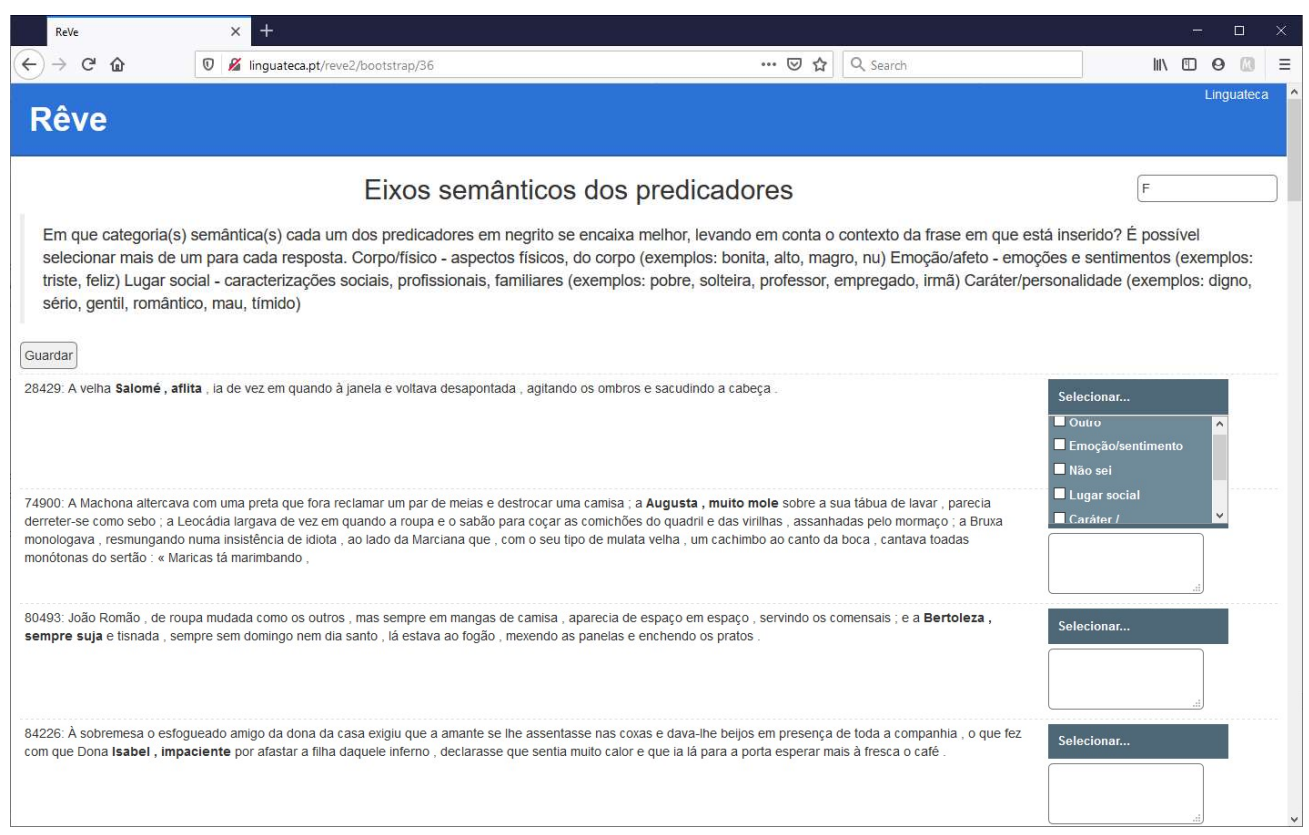

Figura 1 - Visão do teste para os participantes.

\footnotetext{
17 A lista dos predicadores encontrados no corpus aos quais atribuímos classificação múltipla encontra-se no Apêndice 5.
} 
O Rêve oferece ainda uma visualização com dados do teste para auxiliar o linguista na análise dos resultados. A seção de discordâncias foi bastante útil para nossa análise. Não houve nenhuma sentença em que $100 \%$ das respostas tenham sido para apenas uma categoria e alguns dos participantes selecionaram, com frequência, mais de uma alternativa para cada sentença. Nestes últimos casos, sempre que um participante selecionasse mais de uma resposta, acrescentamos um ponto a cada categoria. É possível também que as classificações dadas por apenas uma ou duas pessoas tenham-se devido a uma falta de compromisso com a tarefa dada, tal como já observado por Santos et al. (2015) e Costa \& Freitas (2019). 


\begin{tabular}{|c|c|c|c|c|c|c|c|c|}
\hline Predicador & $\begin{array}{l}\text { Corpo } \\
\text { físico }^{18} \\
\end{array}$ & $\begin{array}{c}\text { Emoção } \\
\text { sentimento } \\
\end{array}$ & $\begin{array}{c}\text { Caráter } \\
\text { Personalidade } \\
\end{array}$ & $\begin{array}{l}\text { Lugar } \\
\text { Social } \\
\end{array}$ & Outro & $\begin{array}{l}\text { Não } \\
\text { sei } \\
\end{array}$ & $\begin{array}{c}\text { Nossa } \\
\text { classificação } \\
\end{array}$ & $\begin{array}{c}\text { Acordo } \\
? \\
\end{array}$ \\
\hline aflita & & 17 & & & 1 & & emoção & $\operatorname{sim}$ \\
\hline mole & 10 & 3 & 9 & & 1 & & caráter/corpo & $\operatorname{sim}$ \\
\hline suja & 14 & & 1 & 1 & 2 & & corpo & $\operatorname{sim}$ \\
\hline impaciente & & 15 & 5 & & 1 & & emoção & $\operatorname{sim}$ \\
\hline lívida & 9 & 4 & 4 & & 1 & 2 & corpo & $\operatorname{sim}$ \\
\hline pobre & & 2 & 1 & 15 & 1 & & social & $\operatorname{sim}$ \\
\hline ágil & 14 & & 4 & & 2 & 1 & corpo & $\operatorname{sim}$ \\
\hline grávida & 14 & 3 & & 1 & 3 & & corpo & $\operatorname{sim}$ \\
\hline aborrecida & & 16 & 1 & & 1 & & emoção & $\operatorname{sim}$ \\
\hline inteligente & & & 14 & & 3 & & caráter & $\operatorname{sim}$ \\
\hline encaminhado & & & & 16 & & 1 & social & $\operatorname{sim}$ \\
\hline indispensável & & 5 & 2 & 4 & 5 & 1 & estado/social & não* \\
\hline fina & 6 & 4 & 8 & 4 & & & caráter & $\operatorname{sim}$ \\
\hline rapagão & 15 & & 2 & & & & corpo & $\operatorname{sim}$ \\
\hline supersticioso & & 3 & 13 & & 2 & & caráter & $\operatorname{sim}$ \\
\hline travesso & & 2 & 16 & & 1 & & caráter & $\operatorname{sim}$ \\
\hline sucumbido & 3 & 13 & 1 & & 1 & & emoção & $\operatorname{sim}$ \\
\hline lânguido & 6 & 5 & 9 & & 1 & & caráter/corpo & parcial $^{*}$ \\
\hline cabeçudo & 8 & & 9 & & 1 & & caráter/corpo & $\operatorname{sim}^{*}$ \\
\hline maçom & & & 2 & 10 & 4 & 1 & social & $\operatorname{sim}$ \\
\hline trêmulo & 7 & 13 & 1 & & 1 & & corpo/emoção & parcial \\
\hline singularíssimo & & & 15 & 2 & & 1 & caráter & $\operatorname{sim}$ \\
\hline trigueiro & 7 & & 7 & 3 & & 1 & corpo & parcial \\
\hline amado & & 11 & 1 & 3 & 1 & 1 & emoção & $\operatorname{sim}$ \\
\hline honesto & & & 15 & 3 & & & caráter & $\operatorname{sim}$ \\
\hline perdido & & 1 & 9 & 8 & & 1 & caráter/social & $\operatorname{sim}$ \\
\hline ocioso & 1 & & 11 & 10 & & 3 & caráter/social & $\operatorname{sim}^{*}$ \\
\hline esfarrapado & 10 & & 1 & 10 & & & corpo/social & $\operatorname{sim}$ \\
\hline varonil & 4 & & 13 & 5 & & 1 & corpo/caráter & parcial \\
\hline válido & 9 & & 4 & 6 & & & erro/corpo & $\operatorname{sim}^{*}$ \\
\hline ímpia & 1 & 1 & 14 & 3 & 1 & & caráter & $\operatorname{sim}$ \\
\hline vulgar & & 2 & 13 & 7 & & & caráter & $\operatorname{sim}$ \\
\hline discreta & 5 & 1 & 13 & 2 & & & caráter & $\operatorname{sim}$ \\
\hline virgem & 10 & & 4 & 5 & 3 & & corpo/social & parcial* $^{*}$ \\
\hline jeitoso & 9 & 1 & 8 & & & & caráter/corpo & $\operatorname{sim}$ \\
\hline escravo & 2 & 1 & 1 & 15 & 1 & & social & $\operatorname{sim}$ \\
\hline caro & & 1 & 6 & 11 & 1 & & caráter/social & parcial* $^{*}$ \\
\hline dócil & 1 & 2 & 14 & 2 & & & caráter & $\operatorname{sim}$ \\
\hline sozinho & 1 & 2 & 1 & 13 & 1 & 1 & social & $\operatorname{sim}$ \\
\hline ardente & 6 & 8 & 10 & 2 & & & caráter/corpo & parcial* $^{*}$ \\
\hline
\end{tabular}

Tabela 2 - Contagem das respostas obtidas no teste do Rêve.

18 O teste foi realizado enquanto a categoria "aparência" era ainda chamada de "corpo/físico". 
Na maioria das sentenças houve uma categoria que se destacou, com aproximadamente o dobro das respostas obtidas nos outros eixos. Nem sempre houve concordância com a nossa interpretação inicial e, em alguns casos, houve alteração da classificação original após o teste: na tabela 2 , em verde, sinalizamos os casos em que a maioria das respostas obtidas condizem com nossa interpretação; em vermelho, a resposta que não condiz. A coluna "nossa classificação" mostra as categorias atribuídas por nós, e os itens com asterisco na última coluna indicam os casos em que houve alteração da classificação original após a análise do teste; as categorias adicionadas às nossas respostas iniciais, após a análise, aparecem em negrito. Analisamos, em seguida, os casos de concordância parcial, alteração e complementação.

\subsubsection{1. - Concordância parcial}

a) Sem alteração da nossa classificação original id="O_Cortiço Prosa:romance AA 1890 naturalismo masc ": -- Ele tem a cabeça virada por uma mulher trigueira .

"Trigueiro" não é um termo comum no falar corrente do Rio de Janeiro, portanto é possível que as pessoas não conhecessem a palavra ${ }^{19}$ - houve, inclusive, uma pessoa que indicou "não sei" como resposta. A definição do dicionário diz que o termo se refere à tonalidade da pele, semelhante à do trigo maduro, ou seja, uma característica física. Durante o processo de atribuição de eixos, classificamos este predicador como corpo/físico. No teste, obtivemos 7 respostas que associaram "trigueiro" ao eixo corpo/físico, duas delas selecionadas por participantes que também votaram em lugar social, optando por mais de uma categorização. Se levarmos em conta o contexto social do país durante o período em que as obras foram escritas, a pele morena, dourada como o trigo, era característica da mulher trabalhadora, que labuta ao ar livre, portanto seria possível também associar o predicador ao eixo lugar social. Chama a atenção 0 fato de 7 anotadores terem selecionado 0 eixo

19 Talvez esta não tenha sido, por este motivo, um bom exemplo para o teste. 
caráter/personalidade, sem sequer terem considerado outro eixo além deste. Compreender como esta categoria teria sido escolhida por tantas pessoas, quando, a princípio, não nos pareceria uma classificação tão óbvia, e nos fez perceber que há ainda mais a se dizer deste predicador. A escolha da categoria caráter/personalidade poderia ter sido determinada pela expressão "cabeça virada por", em que " uma mulher trigueira" é o agente da passiva. Levando em consideração o contexto criado pela estrutura sintática e pelas escolhas lexicais do enunciador da frase, é bastante possível que o sentido de "trigueiro", para essas sete pessoas esteja relacionado a uma sensualidade, que não é (apenas) física, mas um traço de personalidade ou caráter - se percebermos, implícito no enunciado, um certo tom de julgamento. Nesta teia de associações feitas durante a busca por eixos de sentido, características físicas, sociais e traços de caráter/personalidade se entrelaçam, revelando que a frase reforça ainda um estereótipo de gênero: o da mulher não-branca, cuja sensualidade é irresistível e faz os homens perderem o senso. Nossa decisão foi de manter este predicador apenas em corpo/físico, conforme nossa classificação inicial.

id="A_viúva_Simões Prosa:romance JLdA 1895 naturalismo_realismo fem ": (...) Ernestina , trêmula , envergonhava-se da sua mentira , parecendoIhe sentir os olhos do esposo fixos nela.

Este é, para nós, um caso bastante evidente de múltipla categorização, em que o predicador se encaixa tanto no eixo corpo/físico, quanto em emoção/sentimento, pois o tremor do corpo de Ernestina era causado pela vergonha de ter mentido, possivelmente pelo medo de ser descoberta. Oito participantes atribuíram este predicador ao eixo emoção/sentimento, somente dois a corpo/físico e quatro selecionaram as duas alternativas.

id="Contrastes_e_Confrontos Prosa:artigo EdC 1866-1909 masc ": O próprio niilismo, com as suas mulheres varonis, os seus pensadores severos, os seus poetas sentimentais e ferozes, e os seus facínoras românticos (...) 
No total, houve treze votos em caráter/personalidade e sete pessoas selecionaram apenas esta alternativa; três escolheram também lugar social, duas incluíram corpo/físico, e uma selecionou as três categorias. Em nossa interpretação, categorizamos como caráter/personalidade e corpo/físico. Avaliando as discordâncias do teste e o contexto expandido 20 do exemplo, fica bastante evidente a vagueza semântica do predicador, pois não está claro que características as mulheres varonis do niilismo teriam: se físicas, sociais ou de personalidade, portanto permitindo a leitura livre, de que seriam mulheres com aparência, posição social, personalidade ou caráter predominantemente observadas em homens.

b) Com complementação da classificação original (passaram a ter múltipla categorização)

id="Turbilhão Prosa:romance CN 1904 realismo masc ": Ritinha , sempre lânguida , encostada à cômoda , olhava-o com os seus grandes olhos negros, aveludados que , por vezes, pareciam adormecer à sombra dos longos cílios .

Possivelmente por influência da definição dicionarizada, compreendemos "lânguido" como a aparência de cansado, abatido, por isso havíamos classificado este predicador, inicialmente, como corpo/físico. Apenas três participantes selecionaram este eixo como resposta. Embora a maioria dos votos tenha recaído sobre caráter/personalidade - seis pessoas selecionaram somente este eixo, e outras três admitiram a possibilidade de outros eixos, além deste - talvez porque o contexto leve a um entendimento de uma condição permanente, diante do advérbio

\footnotetext{
${ }^{20} i d=" C o n t r a s t e s \_e \_C o n f r o n t o s$ Prosa:artigo EdC 1866-1909 masc ": Conforme um asserto de F. Loliée, o que caracteriza esta mentalidade é a preocupação superior dos fatos morais, o eterno problema altruísta, para que tendem todos os impulsos individuais ou políticos, através de uma análise patética dos menores abalos da natureza humana e visando, essencialmente, no franco estadear dos males profundos da Rússia, estimular as suas grandes aspirações e a sua marcha para o direito e para a liberdade. O próprio niilismo, com as suas mulheres varonis, os seus pensadores severos, os seus poetas sentimentais e ferozes, e os seus facínoras românticos -- um desvario dentro de um generoso ideal -- reponta às vezes, nesta crise, como a forma tormentosa e assombradora da justiça. No conflito o que se distingue bem é o choque inevitável das duas Rússias, a nova, dos pensadores e artistas, e a Rússia tradicional dos czares; o recontro do ária, e do calmuco.
} 
"sempre" -, houve também uma quantidade de votos relevantes que se alinharam à nossa interpretação inicial. Consideramos, por fim, classificar este predicador em caráter/personalidade e corpo/físico.

id="A_Mortalha_de_Alzira Prosa:romance AA 1894 naturalismo_realismo_romantismo masc ": -- Um homem virgem em pleno século dezoito ! ...

O predicador "virgem" pode conferir ao personagem a que se refere o sentido de "sem experiência" ou de "imaculado", sendo culturalmente considerada a "experiência" ou "mácula" a vivência sexual. A virgindade tem, portanto, um valor semântico de corpo/fisico, mas também um peso social, visto como um divisor de águas na vida de uma pessoa - o primeiro encontro sexual como perda da inocência - podendo ser inclusive objeto de julgamentos na sociedade. Ampliando o contexto, vemos que a condição é garantida por um médico, sendo portanto uma característica física e pela fala deste personagem, confirma-se também o sentido de pureza associada à virgindade; já a presença do adjetivo "pleno" e o ponto de exclamação, revelam sutilmente o valor social da virgindade, culturalmente esperada para mulheres e indesejável para homens:

$i d=$ A_Mortalha_de_Alzira_Prosa:romance AA 1894 naturalismo_realismo_romantismo masc ": -- O que há de mais puro! confirmou o médico. -- Um homem virgem em pleno século dezoito! ... Qual! disse Sofia Verriore, soltando uma risada .

Sete participantes do nosso teste atribuíram "virgem" ao eixo corpo/fisico, cinco ao eixo lugar social. Por conta desta análise, classificamos este predicador tanto em lugar social quanto em corpo/fisico.

id="A_Mortalha_de_Alzira_Prosa:romance AA 1894 naturalismo_realismo_romantismo masc ": Começando pelo rei , que fora o seu primeiro amante, pertencera ela depois simultaneamente, ora mais , ora menos tempo, a toda a gente da corte capaz de manter mulheres caras . 
Quando fizemos a categorização inicial, pelo contexto presente na frase, entendemos como "caro" uma característica de personalidade. Uma mulher cara, nesse sentido, parece ser a que que se interessa por coisas que custam muito dinheiro, que somente pessoas ricas poderiam oferecerIhe. Apenas seis participantes da pesquisa também selecionaram caráter/personalidade como eixo semântico, e onze pessoas vêem "caro" como lugar social. Coloca-se uma questão interessante: seriam as mulheres caras mulheres ricas ou com algum tipo de destaque social? Para compreender melhor, ampliamos, mais uma vez, o número de frases em torno do predicador:

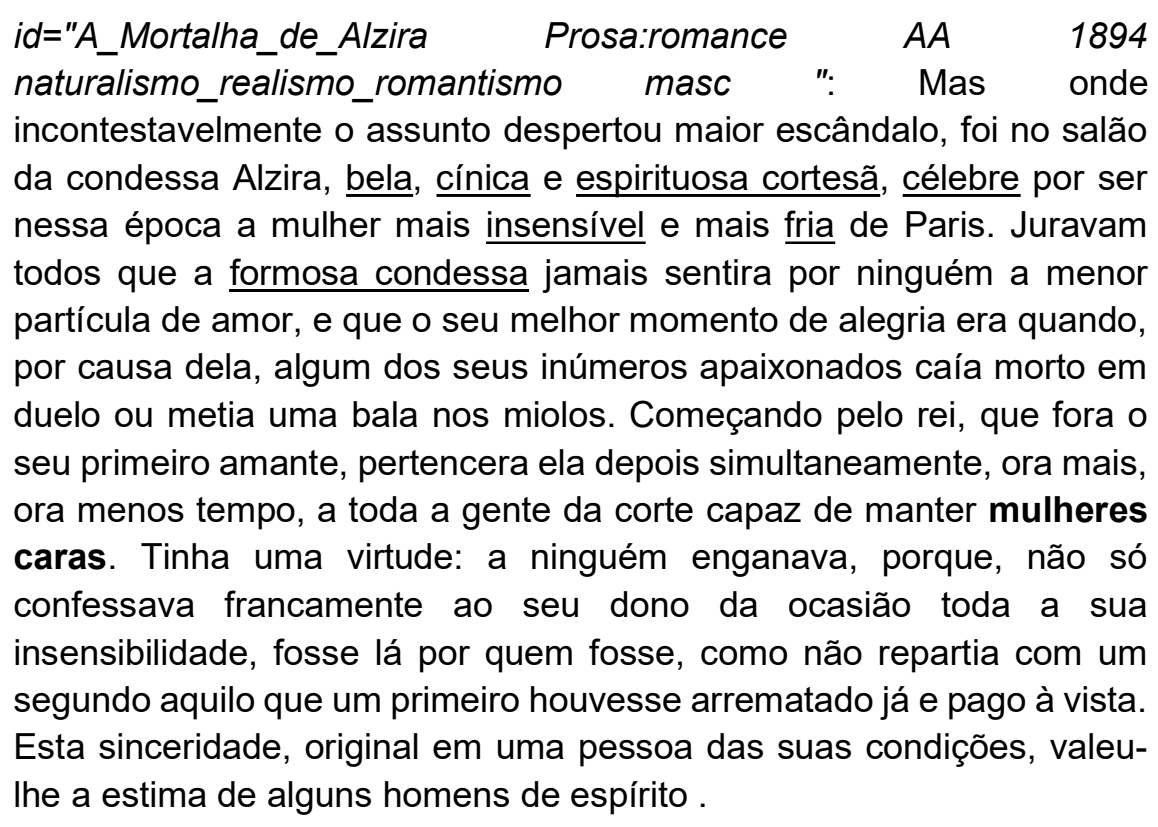

Há, neste trecho, predicadores de todos os eixos empregados na caracterização da condessa Alzira. As escolhas lexicais revelam o tom crítico e jocoso de um narrador divulgando dados da vida privada da condessa, cheio de julgamentos e exageros. Após esta análise, optamos por atribuir a "caro" os dois eixos que, de alguma forma, se mesclam neste caso: caráter/personalidade e lugar social.

id="Turbilhão Prosa:romance CN 1904 realismo masc ": E ele , vencido , dominado por aquela viçosa criatura de amor que , quando andava , bambaleando os quadris e balançando molemente os braços roliços , deixava no ar um cheiro acre de carne , um almíscar estonteante de mulher 
ardente , não teve ânimo de sair e ficou sentado até que ela , ouvindo as horas no lento relógio, veio do fundo da casa, penteando os cabelos lisos , dizer, com espanto :

Uma narrativa como esta, tão rica em detalhes sinestésicos, praticamente nos faz visualizar essa personagem em movimento. ${ }^{21}$ Toda a descrição apresenta detalhes físicos, o único foco é o corpo em movimento da mulher sexualizada, objeto para deleite do olhar masculino (Mulvey, 1973); Classificamos "ardente", inicialmente, apenas no eixo corpo/físico. Entretanto, a categoria mais selecionada entre os participantes foi caráter/personalidade, com dez votos. Emoção/sentimento teve oito votos e corpo físico apenas seis. Possivelmente pela natureza metafórica e abstrata deste predicador tenha sido mais distante a associação ao eixo de corpo/físico. A "ardência" poderia realmente ser uma característica de personalidade (sensualidade), ou consequência de um sentimento, porém parece-nos esta uma associação secundária. Achamos adequado adicionar este predicador também ao eixo caráter/personalidade, para além de corpo/físico.

\subsubsection{2 - Alteração da classificação inicial e divergência}

id="O_Homem Prosa:romance AA 1887 realismo masc ": Em breve , a Justina era tão indispensável para Magdá , quanto uma ama a um orfãozinho recém-nascido .

${ }^{21}$ Expandimos o contexto para identificar a personagem descrita e o que disse. id="Turbilhão Prosa:romance CN 1904 realismo masc ": Fora à estalagem procurá-lo e encontrara Ritinha só, sempre dengosa, que o recebera toda risonha, com os seus dentinhos miúdos muito brancos e os seus olhos quentes como dois carvões acesos. Não o deixara sair: que esperasse um instante: Mamede não se demorava. E ele, vencido, dominado por aquela viçosa criatura de amor que, quando andava, bambaleando os quadris e balançando molemente os braços roliços, deixava no ar um cheiro acre de carne, um almíscar estonteante de mulher ardente, não teve ânimo de sair e ficou sentado até que ela, ouvindo as horas no lento relógio, veio do fundo da casa, penteando os cabelos lisos, dizer, com espanto: " Que, deveras, Mamede estava demorando muito. Ele não costumava ficar até aquelas tantas na rua». 
Ao depararmo-nos com "indispensável" na lista de distribuição não fomos capazes de definir imediatamente um eixo; pensamos tratar-se de um estado, portanto não classificamos em nenhuma das quatro categorias. No teste, obtivemos 5 respostas para emoção/sentimento, 5 para outro e 4 para lugar social, não havendo nenhuma categoria que se destaque. Dentre os participantes que selecionaram outro, apenas um sugeriu o que seria essa outra alternativa, a que chamou de "nível de importância". Um participante selecionou a alternativa não sei. A diversidade de respostas confirma a dificuldade de classificação deste predicador nos eixos propostos. Refletindo sobre nossa ideia inicial de classificar "indispensável" como "estado", e pela sugestão do participante da pesquisa de que um possível eixo seria "nível de importância", passamos a considerá-lo um status, portanto compatível com lugar social, porque se refere a relações interpessoais, apesar de não ser uma associação tão óbvia. Para fins de avaliação, consideramos este caso como uma divergência, pois as respostas dadas pelos participantes do teste não são conclusivas quanto à categoria, difererindo da nossa categorização final como lugar social.

\subsubsection{3 - Complementação que gerou concordância total}

id="O_ermitão_do_Muquém Prosa:romance BG 1868 romantismo_regionalismo masc ": Era uma malta de rapazes ociosos e devassos, da qual ele por sua superioridade em forças e destreza e por sua riqueza e generosidade era o chefe natural .

Havíamos classificado "ocioso" em caráter/personalidade, mas o teste resultou quase num empate entre esta categoria e lugar/social, que também é aceitável, no sentido de se estar sem uma ocupação formal, desempregado. Quatro participantes votaram, inclusive, nessas suas categorias simultaneamente. É provável que a coordenação com o predicador "devasso" esteja reforçando o tom crítico do enunciador e nos direcionando a incluir "ocioso" na categoria de caráter/personalidade, como se o ócio pudesse ser uma atitude ou comportamento reprovável, e não 
necessariamente uma condição social. Portanto, após a análise, incluímos este predicador também lugar/social, entrando para a lista de predicadores com múltipla categorização. O dicionário corrobora esta classificação ${ }^{22}$.

id="O_missionário Prosa:romance IdS 1891 naturalismo masc ": Padre Marcelino era cabeçudo, sem entranhas, de poucas brincadeiras, e tinha ódio mortal a tudo que era ou lhe parecia maçom .

Se considerarmos o predicador enquanto uma entrada lexical, podemos dizer que estamos diante de mais um caso de múltipla categorização, em que o "cabeçudo" poder-se-ia referir tanto referir a um aspecto físico (o tamanho da cabeça) quanto a um traço de personalidade, no sentido de ser-se teimoso ou inteligente, por metáfora do sentido anterior. As respostas do teste foram empatadas entre os dois eixos. Neste contexto, entretanto, considerando que, os demais predicadores coordenados nessa sentença, se referem apenas de características de personalidade e emocionais, parece-nos que "cabeçudo" está mais próximo do sentido de teimoso, e por este motivo nossa classificação foi inicialmente caráter/personalidade, mas concordamos em seguir com a múltipla categorização porque, em outros contextos, corpo/físico também é possível ${ }^{23}$.

Conseguimos confirmar as categorias como válidas para a predicação de pessoas, pois foram bem aceitas pelos participantes. Nos 40 predicadores analisados, tivemos $80 \%$ de análises convergentes, e em $18 \%$ dos casos houve alguma divergência entre o resultado do teste e a nossa proposta; e vale lembrar que, em um dos casos de concordância parcial (trigueiro), temos consciência de que parte da classificação fornecida pelos participantes estava errada, e o caso que consideramos discordante (indispensável) é realmente de difícil classificação. O número de convergências é bastante bom no contexto da concordância

\footnotetext{
22 http://www.aulete.com.br/ocioso oferece os dois sentidos: sem trabalho, preguiçoso, vadio

${ }^{23}$ Um desdobramento futuro inevitável, para garantir a alta qualidade das análises, é um processo de revisão do corpus anotado, justamente para um ajuste fino. A anotação por meio de léxicos é um grande passo inicial, mas precisa de aprimoramento.
} 
interanotadores (Arstein, 2017) - que não é exatamente a mesma coisa do que fizemos, mas serve como uma medida a respeito do que esperar dos resultados. $O$ teste permitiu-nos ainda aperfeiçoar nossa própria percepção dos sentidos tomados pelos predicadores no contexto em que ocorrem e sua distribuição pelos eixos. Nem sempre a distribuição foi tão óbvia, como vimos, mas foi proposital a escolha de incluir os casos complicados entre outros mais simples, na elaboração do teste. Assim, para além de validar as categorias, o teste serviu para que melhorássemos nossa classificação nos seguintes casos: ardente, caro, virgem, indispensável, ocioso e cabeçudo.

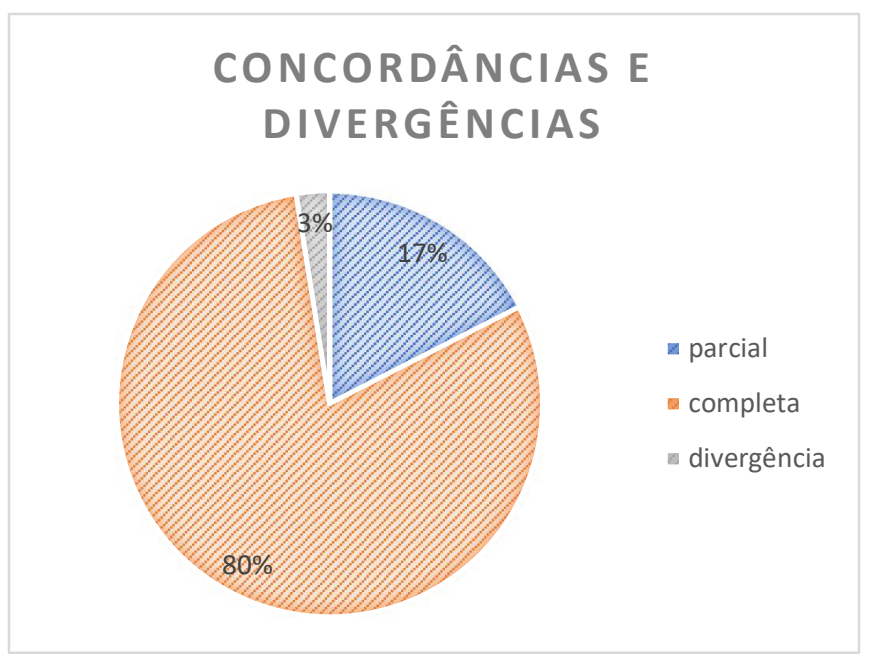

Gráfico 1 - Resultados do teste do Rêve: concordâncias e divergências.

As listas de correspondência entre os predicadores e as categorias foram utilizadas para adicionar mais uma camada de anotação semântica ao corpus OBras, possibilitando também buscas de predicadores no AC/DC por eixo semântico ${ }^{24}$.

${ }^{24} \mathrm{O}$ trabalho está em andamento, em fase de implementação. 


\subsection{Desenvolvimento de expressões de busca por ações}

Uma outra forma de buscar maneiras de caracterizar personagens, tendo o gênero como operador analítico, é por meio das ações que realizam, ou seja, verificar se há ações mais tipicamente associadas a personagens masculinas ou femininas, por exemplo, aproveitando a anotação morfossintática do corpus. Mais uma vez, procuramos identificar padrões morfossintáticos, mas desta vez, que nos indicassem relações de sujeito-predicado. Muita coisa, certamente, fica de fora. Por exemplo, sabemos que há muitos casos de sujeitos ocultos corpus, uma característica da língua portuguesa muito comum em textos escritos, que infelizmente nos impede de identificar o autor da ação, utilizando a leitura distanciada, para alguns trechos das obras, visto que as anotações sintáticas são feitas no âmbito da frase. Freitas e De Souza (2021) observam, por exemplo, que em todo o OBras há $41 \%$ de sujeitos ocultos.

Levamos duas condições em consideração: garantir que os resultados não trouxessem os verbos "ser", "estar" e "haver" e que as ações obtidas não estivessem sendo negadas na frase, portanto, caso houvesse um advérbio modificando o verbo no predicado, não poderia ser nem "não", nem "nunca". Após algumas experiências, chegamos, por fim, às seguintes expressões de busca:

\section{Verbos na voz ativa}

\section{Sujeito anteposto}

\section{a. Nomes próprios marcados com a etiqueta semântica "Pessoa"}

Feminino:

$$
\begin{aligned}
& \text { [sema="."Pessoa." \& gen="F" \& func="SUBJ>"] [pos="ADV. *" \& }
\end{aligned}
$$

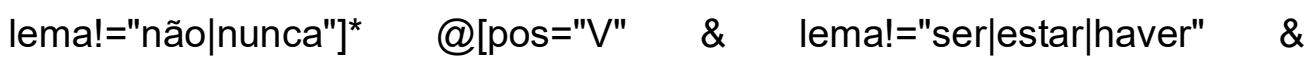

$$
\begin{aligned}
& \text { temcagr!="PASS|PCP"] }
\end{aligned}
$$


id="A_viúva_Simões Prosa:romance JLdA 1895 naturalismo_realismo fem ": Ernestina corou, mas Sara, muito ingênua, não deu por tal.

Masculino:

[sema=".*Pessoa." \& gen="M" \& func="SUBJ>"] [pos="ADV.*" \& lema!="não|nunca"] $\quad @[p o s=" \bigvee " \quad \& \quad$ lema!="ser|estar|haver" \& temcagr!="PASS|PCP"]

id="Banzo Prosa:contos CN 1912 realismo masc ": Marcos gemia, curvando-se, a repassar a mão no ventre côncavo.

\section{b. Pronome pessoal $3^{\text {a }}$. Pessoa}

Feminino:

[lema="ela" \& func="SUBJ>"] @[pos="V" \& lema!="ser|estar|haver" \& temcagr!="PASS|PCP"]

id="O_carro_no._13 Prosa:conto MdA 1868 masc ": Eu creio que ela gosta de $\operatorname{mim} .$.

Masculino:

[lema="ele" \& func="SUBJ>"] @[pos="V" \& lema!="ser|estar|haver" \& temcagr!="PASS|PCP"]

id="A_falência Prosa:romance JLdA 1901 naturalismo_realismo fem ": Só ele resistira, firme nos seus princípios de moral e de economia.

\section{c. Substantivo comum indicador de relação de parentesco}

Feminino:

[sema="parentesco" \& gen="F" \& func="SUBJ>"] [word="de|do|da"]" [sema="Pessoa"] ${ }^{*} \quad$ [pos="ADV."" \& lema!="não|nunca"] ${ }^{*} @[p o s=" V " ~ \&$ lema!="ser|estar|haver" \& temcagr!="PASS"] 
id="O_gaúcho Prosa:romance JdA 1870 romantismo_regionalismo masc ": A filha do Lucas tremia com a idéia de deixar só a amiga e por isso a obrigou a ficar em sua companhia.

Masculino:

[sema="parentesco" \& gen="M" \& func="SUBJ>"] [word="de|do|da"] [sema="Pessoa"] ${ }^{*}$ [pos="ADV."" \& lema!="não|nunca"]* @[pos="V" \& lema!="ser|estar|haver" \& temcagr!="PASS"]

id="O_alienista Prosa:novela MdA 1882 realismo masc ": Não desmaiou; correu à sala interior onde o marido estudava.

\section{d. Substantivo comum indicador de pessoa, segundo o gênero}

Feminino:

[lema="mulher|moça|rapariga|menina|senhora" ～\& func="SUBJ>"] @[pos="V" \& lema!="ser|estar|haver" \& temcagr!="PASS"]

id="Histórias_sem_Data Prosa:conto MdA 1884 masc ": Os que eram homens fumavam; as mulheres cantavam ao piano.

Masculino:

[lema="homem|moço|rapaz|menino|senhor" \& func="SUBJ>"] @[pos="V" \& lema!="ser|estar|haver" \& temcagr!="PASS"]

id ="O_Ateneu $\quad$ Prosa:romance $\quad$ RP 1888 impressionismo_naturalismo_realismo_simbolismo masc ": Os rapazes berravam como loucos.

\section{Sujeito posposto}

a. Nomes próprios marcados com a etiqueta semântica "Pessoa" 
Feminino:

[pos="V" \& lema!="ser|estar|haver" \& temcagr!="PASS|PCP"]

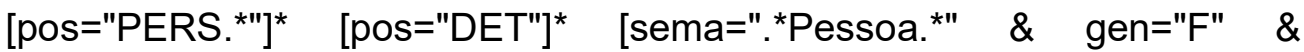
func="<SUBJ"]

id="A_conquista Prosa:romance CN 1899 realismo masc ": Mamãe, choramingou Vidinha, é melhor abrir...

Masculino:

[pos="V" \& lema!="ser|estar|haver" \& temcagr!="PASS|PCP"] [pos="PERS." ${ }^{*} \quad[$ pos="DET"]* [sema="..Pessoa.*" \& gen="M" \& func="<SUBJ"]

id="O_Matuto Prosa:romance FT 1878 realismo_regionalismo_romantismo masc": Planejava Lourenço queimar vivo o infeliz.

\section{b. Pronome pessoal $3^{a}$. Pessoa}

Feminino:

[pos="V" \& lema!="ser|estar|haver" \& temcagr!="PASS|PCP"] [pos="PERS. *"]* [pos="DET"] [lema="ela" \& func="<SUBJ"]

id="D._Benedita Prosa:conto MdA 1882 masc ": -- Isto acaba, murmurou ela, vindo para dentro.

Masculino:

[pos="V" \& lema!="ser|estar|haver" \& temcagr!="PASS|PCP"] [pos="PERS.*"]* [pos="DET"] [lema="ele" \& func="<SUBJ"]

id="O_Mulato Prosa:romance AA 1881 naturalismo masc ": Não tenho apetite algum! ... resmungava ele, abrindo a boca .

\section{c. Substantivo comum indicador de relação de parentesco}


Feminino:

[pos="V" \& lema!="ser|estar|haver" \& temcagr!="PASS|PCP"] [pos="PERS."]* [pos="DET"]* [sema="parentesco" \& gen="F" \& func $="<$ SUBJ"]

id="Encher_tempo Prosa:conto MdA 1876 masc ": -- Fui e vim com o credo na boca, terminou tia Mônica; e dou graças à Virgem Santíssima por me ver aqui sã e salva .

Masculino:

[pos="V" \& lema!="ser|estar|haver" \& temcagr!="PASS|PCP"] [pos="PERS.*"]* [pos="DET"]* [sema="parentesco" \& gen="M" \& func="<SUBJ"]

id="A_alma_de_Lázaro Prosa:novela JdA 1873 romantismo_histórico masc ": Era mãe a pátria, que defendiam filhos dedicados .

d. Substantivo comum indicador de pessoa, segundo o gênero

Feminino:

[pos="V" \& lema!="ser|estar|haver" \& temcagr!="PASS|PCP"] [pos="PERS.*"]* [pos="DET"] [lema="mulher|moça|rapariga|menina|senhora" \& func="<SUBJ"]

id="Inocência $\quad$ Prosa:romance VdT 1872 realismo_regionalismo_romantismo masc ": O corpo ali estava, mas a sua imaginação vigiava zelosa o quartinho onde repousava aquela menina febricitante, tão bela na sua fraqueza e palidez enferma .

Masculino:

[pos="V" \& lema!="ser|estar|haver" \& temcagr!="PASS|PCP"] [pos="PERS.*"]* [pos="DET"]* [lema="homem|moço|rapaz|menino|senhor" \& func="<SUBJ"] 


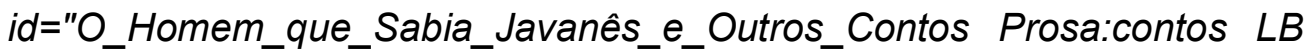
1997 masc ": Vieram homens mais robustos e mais cheios de ousadia, sem mesmo dependência sentimental com os dominadores, pois não se deixavam explorar facilmente, como os naturais .

A busca por ações, da mesma forma que para os predicadores, foi feita concatenando apenas as expressões para a voz ativa, individualmente descritas acima, para obtermos duas listas de ocorrências, uma para cada gênero. As expressões exatas usadas estão no Apêndice 6. Os verbos com sujeitos pospostos são, em maioria, verbos cujo campo semântico está relacionado a "dizer". Além disso, identificamos alguns problemas na anotação automática que são previsíveis, dada a estrutura da língua; a estrutura indicadora de sujeito posposto, por exemplo, resulta frequentemente na obtenção de objetos. Casos como o do exemplo a seguir aparecem bastante no corpus:

id="Inocência $\quad$ Prosa:romance $\quad$ VdT 1872 realismo_regionalismo_romantismo masc ": Tenho cinco filhos, três machos e duas famílias, estas casadas, e que me deram netos ${ }^{25}$; já faz bastante tempo.

Também testamos a busca por verbos na voz passiva, e percebemos alguns resultados incorretos pois identificamos casos em que o agente da passiva está anotado como objeto do verbo, portando também optamos por não considerar os resultados obtidos neste cenário. Vale ressaltar que o trabalho de anotação foi feito automaticamente, e correções vêm sendo feitas pelos linguistas colaboradores do projeto conforme seja possível. Em prol da precisão dos resultados, deixamos esses dois cenários de fora.

Outras possibilidades de exploração possíveis para ações seriam descobrir o modo como elas são executadas ou seus complementos, objetos etc. Nestes casos, é importante usar o verbo específico como

\footnotetext{
${ }^{25}$ A palavra "netos" está anotada como sujeito, mas na verdade é um objeto direto.
} 
delimitador. Para estes casos identificamos os padrões e criamos as expressões de busca, que apresentamos, já concatenadas, usando os quatro indicadores de pessoas:

1) Como respondem? (Advérbios)

Femininos:

[sema=".*Pessoa.*" \& gen="F" \& func="SUBJ>"] [pos="ADV.*" \& lema!="não|nunca"] ${ }^{*} \quad[$ pos="V" \& lema="responder" \& temcagr!="PASS|PCP"] [pos="ADV. *"]* @[pos="ADV. |ADJ. *|PCP"]| [sema="parentesco" \& gen="F" \& func="SUBJ>"] [word="de|do|da"]* [sema="Pessoa"] ${ }^{*} \quad\left[\right.$ pos="ADV. *" \& lema!="não|nunca"] ${ }^{*}$ [pos="V" \& lema="responder" \& temcagr!="PASS"] [pos="ADV.*"]* @[pos="ADV. .|ADJ. *|PCP"]|

[lema="mulher|moça|rapariga|menina|senhora" \& func="SUBJ>"] [pos="V" \& lema="responder" \& temcagr!="PASS"] [pos="ADV.*"]* @[pos="ADV.*|ADJ. *|PCP"]|

[lema="ela" \& func="SUBJ>"] [pos="V" \& lema="responder" \& temcagr!="PASS|PCP"] [pos="ADV. *"]* @[pos="ADV. *|ADJ.*|PCP"]

id="Quem_não_quer_ser_lobo... Prosa:conto MdA 1872 masc ": Lúcia respondeu ingenuamente.

Masculinos:

[sema=".*Pessoa.*" \& gen="M" \& func="SUBJ>"] [pos="ADV.*" \& lema!="não|nunca"] ${ }^{*} \quad[$ pos="V" \& lema="responder" \& temcagr!="PASS|PCP"] [pos="ADV. *"]* @[pos="ADV.*|ADJ. *|PCP"]| [sema="parentesco" \& gen="M" \& func="SUBJ>"] [word="de|do|da"]*

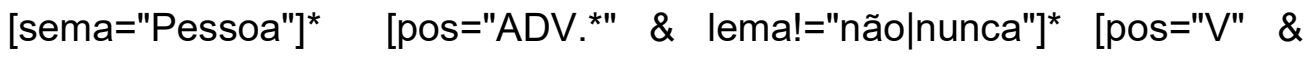
lema="responder" \& temcagr!="PASS"] [pos="ADV.*"] $@\left[\right.$ pos="ADV. $\left.{ }^{*}\left|A D J .{ }^{*}\right| P C P "\right] \mid$

[lema="homem|moço|rapaz|menino|senhor" \& func="SUBJ>"] [pos="V" \& lema="responder" \& temcagr!="PASS"] [pos="ADV.*"] @[pos="ADV. $\left.{ }^{*}\left|A D J .{ }^{*}\right| P C P "\right] \mid$

[lema="ele" \& func="SUBJ>"] [pos="V" \& lema="responder" \& temcagr!="PASS|PCP"] [pos="ADV. *"]* @[pos="ADV..|ADJ.*|PCP"] 
id="Nem_uma_nem_outra Prosa:conto MdA 1873 masc ": O velho não reparava nisso, ficou muito admirado quando o sobrinho respondeu secamente às últimas palavras dele:

2) $O$ que não fazem ou não podem fazer? ${ }^{26}$

Feminino:

[sema=".*Pessoa."” \& func="SUBJ>" \& gen="F"] [word="não|nunca"] [lema="poder"]* @[pos="V"]|

[sema="parentesco" \& gen="F" \& func="SUBJ>"] [word="de|do|da"] [lema="mulher|moça|rapariga|menina|senhora" \& func="SUBJ>"] [word="não|nunca"] [lema="poder"] @ @[pos="V"]| [lema="ela" \& func="SUBJ>"] [word="não|nunca"] [lema="poder"] @[pos="V"] id="O_moço_louro Prosa:romance JMdM 1845 romantismo masc ": -- D. Honorina não respeita as cãs da velhice; e atreve-se a requestar um ancião respeitável! ...

Masculino:

[sema=".*Pessoa.*" \& func="SUBJ>" \& gen="M"] [word="não|nunca"] [lema="poder"]" @[pos="V"]|

[sema="parentesco" \& gen="M" \& func="SUBJ>"] [word="de|do|da"] [sema="Pessoa"]” [word="não|nunca"] [lema="poder"]* @[pos="V"]| [lema="homem|moço|rapaz|menino|senhor" \& func="SUBJ>"] [word="não|nunca"] [lema="poder"]* @[pos="V"]| [lema="ele" \& func="SUBJ>"] [word="não|nunca"] [lema="poder"] @[pos="V"]

id="Ressurreição Prosa:romance MdA 1872 romantismo masc ": Meneses não fraqueou na defesa da sua hipótese.

Entretanto, nesta dissertação, não realizamos as análises para estes padrões, esperaramos explorar futuramente. Embora a busca por ações

${ }^{26}$ Nesta expressão quisemos explicitar a negação. 
não tenha sido exaustiva, estes foram os padrões que encontrados e utilizados nesta pesquisa. Passaremos, em seguida, às análises feitas sobre as listas de ocorrências obtidas nas buscas. 


\section{Análise dos resultados}

\subsection{Predicadores}

Após obtermos as listas de distribuição dos predicadores no corpus e classificá-los de acordo com os eixos semânticos, começamos a "alterar as lentes" do nosso olhar. Vamos observar que aparência gráfica toma essa distribuição. Os gráficos abaixo apresentam a diversidade lexical das predicações, por eixo e por gênero, sem levar em conta a frequência.

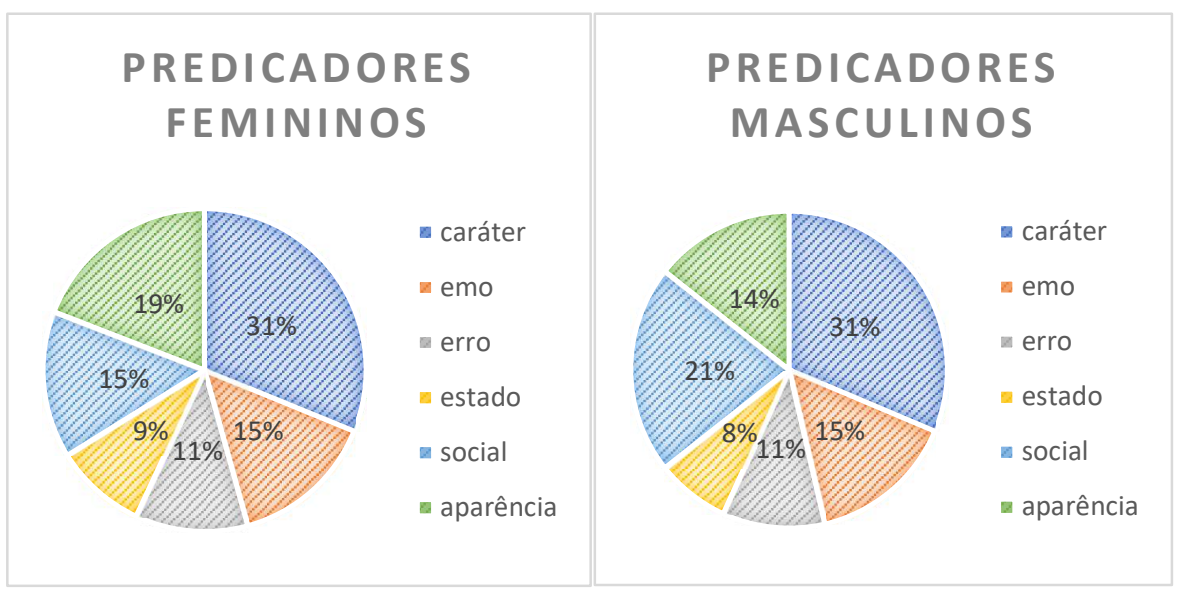

Gráficos 2 e 3 - Distribuição da contagem de predicações obtidas (lemas), representando a diversidade lexical por eixo, desconsiderando o número de vezes que cada uma aparece no corpus.

Nos gráficos acima vemos que a distribuição das predicações por eixo é parecida para os dois gêneros. A maior parte dos predicadores obtidos se refere ao caráter/ personalidade dos personagens $(31 \%)$ e também o índice de erros foi igual para os dois gêneros (11\%). As únicas categorias que diferem são aparência e lugar social, pois observamos mais palavras indicadoras de aspectos físicos para caracterizar as mulheres, e de papeis sociais para homens. Ainda acerca da diversidade lexical de predicações, a maioria ocorre para os dois gêneros, mas há um considerável número de lemas que aparecem somente para um dos gêneros. Somente personagens masculinos são retratados como valentes, 
honrados, maduros e públicos ${ }^{27}$, e apenas as mulheres, como ciumentas, gentis, formosas e íntimas. Apresentamos os resultados das predicações exclusivas mais frequentes nas tabelas a seguir.

\begin{tabular}{|c|c|c|c|c|c|c|c|c|c|}
\hline \multicolumn{2}{|c|}{ emocão masculina } & \multicolumn{2}{|c|}{ caráter masculino } & \multicolumn{2}{|c|}{ "aparência masculina } & \multicolumn{2}{|c|}{ social masculino } & \multicolumn{2}{|c|}{ estado masculino } \\
\hline predicador & qtd & predicador & qtd & predicador & qtd & predicador & qtd & predicador & qtd \\
\hline valente & 15 & honrado & 24 & maduro & 8 & público & 20 & ferido & "6 \\
\hline entusiasmado & 6 & ilustre & 10 & barbado & 5 & filho & 15 & arruinado & 3 \\
\hline furioso & 6 & sábio & 9 & calvo & 4 & político & 11 & esquecido & 2 \\
\hline corajoso & 5 & rude & 7 & criança & 4 & notável & 10 & deitado & 3 \\
\hline deslumbrado & 4 & malcriado & 7 & baixinho & 3 & importante & 10 & desinteressado & 2 \\
\hline misericordioso & 4 & seguro & 6 & teso & 3 & capitão & 9 & diferente & 2 \\
\hline feroz & 4 & amável & 6 & rijo & 3 & português & 8 & incomodado & 2 \\
\hline apressado & 3 & sagaz & 5 & imberbe & 3 & empregado & 8 & inerte & 2 \\
\hline vexado & 3 & morigerado & 5 & rapaz & 3 & primitivo & 7 & estremunhado & 2 \\
\hline apreensivo & 3 & útil & 5 & vesgo & 2 & pai & 7 & atorrear & 1 \\
\hline pacato & 3 & indiferente & 5 & quadragenário & 2 & feudal & 6 & internado & 1 \\
\hline hediondo & 3 & extraordinário & 5 & galhardo & 2 & formado & 6 & endefluxado & 1 \\
\hline impassivel & 3 & franco & 5 & esguio & 2 & negociante & 6 & entretidíssimo & 1 \\
\hline insolente & 3 & singular & 5 & mascarar & 2 & célebre & 6 & mortinho & 1 \\
\hline bravo & 3 & mediocre & 4 & brioso & 2 & oficial & 5 & contorsionar & 1 \\
\hline humilde & 3 & probo & 4 & espadaúdo & 2 & poderoso & 5 & lavadinho & 1 \\
\hline maravilhado & 3 & tenaz & 4 & ágil & 2 & rústico & 4 & detido & 1 \\
\hline respeitoso & 3 & moderno & 4 & tisnado & 2 & sócio & 4 & equipado & 1 \\
\hline folgazão & 3 & polido & 4 & miúdo & 2 & trabalhador & 4 & agitante & 1 \\
\hline audacioso & 2 & decente & 4 & bonitinho & 2 & poeta & 4 & rojar & 1 \\
\hline
\end{tabular}

Tabela 3 - Lista das vinte predicações exclusivas (lemas) mais frequentes para personagens masculinos.

\begin{tabular}{|c|c|c|c|c|c|c|c|c|c|}
\hline \multicolumn{2}{|c|}{ emoção feminina } & \multicolumn{2}{|c|}{ caráter feminino } & \multicolumn{2}{|c|}{ aparência feminina } & \multicolumn{2}{|c|}{ social feminino } & \multicolumn{2}{|c|}{ estado feminino } \\
\hline predicador & qtd & predicador & qtd & predicador & qtd & predicador & qtd & predicador & qtd \\
\hline ciumento & 6 & gentil & 8 & formoso & 38 & filha & 15 & desmaiado & 4 \\
\hline faceiro & 6 & má & 6 & lindo & 18 & mãe & 14 & enganado & 4 \\
\hline indiferente & 5 & namoradeiro & 5 & encantador & 17 & íntimo & 4 & embebido & 3 \\
\hline adorável & 5 & Ioureira & 5 & grávido & 6 & primo & 3 & confuso & 3 \\
\hline choroso & 4 & trabalhadeira & 4 & moca & 6 & empregada & 3 & ciente & 2 \\
\hline desgraçado & 4 & senhora & 4 & maltrapilho & 5 & solteira & 3 & suspeito & 2 \\
\hline ofendido & 3 & atento & 4 & esplêndido & 5 & rainha & 3 & cônscio & 2 \\
\hline espavorido & 3 & insensivel & 4 & galante & 5 & donzela & 3 & estendido & 2 \\
\hline surdo & 3 & ingênuo & 4 & ardente & 5 & comum & 3 & transido & 2 \\
\hline amuado & 2 & angélico & 4 & tísico & 4 & supremo & 3 & inexperiente & 2 \\
\hline agradecido & 2 & romanesco & 3 & cansado & 4 & núbil & 2 & desfalecido & 2 \\
\hline afortunado & 2 & ímpio & 3 & sereno & 4 & chic & 2 & próximo & 2 \\
\hline culpado & 2 & frivolo & 3 & jovem & 4 & cozinheira & 2 & ultrapassado & 1 \\
\hline carinho & 2 & trêfego & 3 & másculo & 3 & parenta & 2 & recém-aparecer & 1 \\
\hline amoroso & 2 & bondoso & 3 & são & 3 & inglês & 2 & retido & 1 \\
\hline envergonhado & 2 & divino & 3 & sujo & 3 & desquitado & 2 & entretido & 1 \\
\hline fúria & 1 & morfético & 2 & preto & 3 & noiva & 2 & desprevenido & 1 \\
\hline desventuroso & 1 & prendado & 2 & alvo & 3 & espanhol & 2 & salteado & 1 \\
\hline agastado & 1 & rebelde & 2 & quarentão & 2 & desamparado & 2 & debruçado & 1 \\
\hline chorão & 1 & bem-educado & 2 & setuagenário & 2 & escrava & 2 & predisposto & 1 \\
\hline
\end{tabular}

Tabela 4 - Lista das vinte predicações exclusivas (lemas) mais frequentes para personagens femininos.

${ }^{27}$ Isto se deve à expressão "homem público", que, segundo o dicionário Houaiss, indica "indivíduo que ocupa um alto cargo do Estado", e que não tem um equivalente para pessoas do gênero feminino - "mulher pública". 
A tabela acima mostra as caracterizações mais frequentes que aparecem apenas para um dos gêneros ${ }^{28}$. Se começarmos a análise pela primeira linha da tabela, vemos, entre as caracterizações masculinas, "honrado" aparecendo em primeiro lugar, com 24 ocorrências, seguido por "público" (20) e "valente" (15), e por último a característica do eixo aparência, "maduro" com apenas 8 ocorrências. Para os femininos, é o eixo aparência que se destaca, com o predicador "formosa" aparecendo 38 vezes, seguido por "filha" no eixo lugar social (15), "gentil" (8) e "ciumenta" (6). Tal como "bonita" é um outlier no total de predicadores, ocorrendo 146 vezes no corpus, entre os exclusivos para um gênero também vemos "formosa" como o ponto fora da curva entre todos os predicadores femininos exclusivos, seguido em seu eixo por "linda" e "encantadora", com aproximadamente metade das ocorrências de cada um. A descrição da aparência é tão predominante para as personagens femininas que os três mais frequentes, dentre todos os predicadores exclusivos femininos, são deste eixo.

Um esclarecimento, ainda não feito até este momento, faz-se necessário, em relação aos substantivos obtidos nas listas de predicações. Adjetivos, como "bonito" e "bonita", são anotados no corpus como tendo o mesmo lema (sempre sendo a versão masculina singular), enquanto os predicadores anotados como substantivo, como "empregado" e "empregada" 29 , têm lemas distintos para a forma masculina e a feminina (no singular), por isso vemos ambos os nomes na lista de predicações únicas para cada gênero.

Levando isto em consideração, é esperado ver "mãe" e "pai", assim como "filho" e "filha", surgirem na lista de predicações exclusivas a um dos gêneros, no eixo lugar social, assim como nomes de ocupações profissionais ou não. Mas é possível identificar que, nesse eixo, nomes ligados à esfera doméstica são mais comuns entre as predicações

28 Lembrando que nossas expressões de busca cobrem um grande número de predicações, mas não dão conta da totalidade de predicações presentes no corpus, conforme explicado no capítulo 3.

${ }^{29} \mathrm{Na}$ anotação do PALAVRAS, adjetivos têm lema na forma do masculino singular e substantivos no singular, visto que substantivos não flexionam em gênero. 
femininas, enquanto entre as masculinas, observam-se mais frequentemente caracterizações referentes a relações sociais fora da esfera familiar. Entre os masculinos, "público" (de "homem público") aparece 20 vezes, "político", 11, "notável" e "importante", 10 vezes cada. "Filho" aparece 15 vezes, "pai", 7. Entre as ocupações / status social mais frequentes, além de político", encontramos "capitão", "feudal" (de "senhor feudal"), “empregado", “negociante", "formado". Entre os femininos, aparecem no topo "filha" (15 vezes) e "mãe" (14). O terceiro mais frequente, ainda neste eixo, "íntimo" tem apenas 4 ocorrências. Dentro do ambiente doméstico / familiar, vemos ainda "prima", "solteira", "parenta", os estados civis "solteira" e "desquitada", "ocupações" como "empregada", "cozinheira" e "escrava".

$\mathrm{Na}$ área das emoções, aparecem muitos predicadores comuns ao dois gêneros, por isso vemos tão poucos surgindo entre as predicações exclusivas. O que nos salta aos olhos é, entretanto, o predicador "valente", com 15 ocorrências enquanto predicador masculino, e que não aparece entre as predicações femininas. E "valente", para nós, encaixa-se tanto no eixo emoção/sentimento, quanto em caráter/personalidade. Neste último, é interessante ver quão frequentemente eles são "honrados", "ilustres" e "sábios" - e surpreendente ver estes entre predicações exclusivas masculinas, pois esperaríamos que em nossa literatura dos séculos passados também se fizesse menção a mulheres honradas e sábias enquanto elas são "gentis" ou "más". Neste ponto, voltamos a lembrar que nossas expressões dão conta de muitos casos, ao menos entre os contextos sintáticos mais comuns na nossa língua, mas não de todos. $A$ ausência desses predicadores pode ser fruto também de erros de anotação, e é possível que as mulheres honradas, valentes e sábias estejam mencionadas no corpus; mas, não resta dúvida, após esta análise, de que apareçam menos do que os homens com estas qualidades.

Após esta breve análise da variedade lexical dos predicadores obtidos, vamos observar, a seguir, gráficos que mostram a distribuição dos 
predicadores nas nossas categorias, desta vez levando em consideração a quantidade de vezes em que ocorrem.

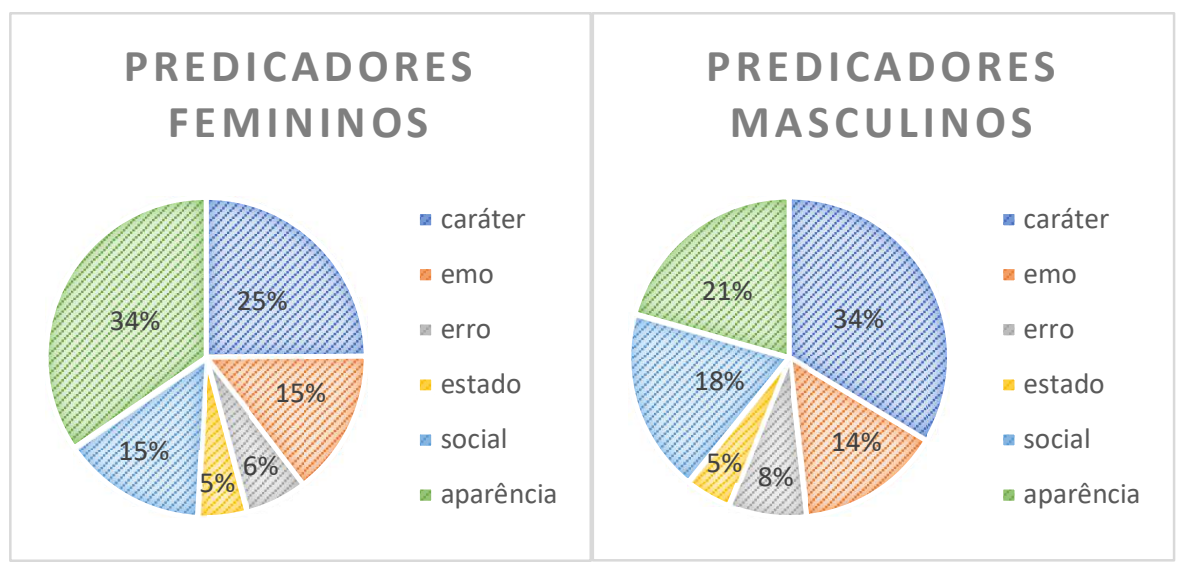

Gráficos 4 e 5 - Distribuição dos predicadores quanto ao gênero, pelas categorias semânticas, considerando o número de vezes que cada um ocorre.

Nesta análise, iremos trabalhar apenas com quatro categorias semânticas, deixando de lado, por ora, os casos que classificamos como estado, para serem analisados em trabalhos a serem desenvolvidos futuramente, e também porque muitos desses casos se devem a formas participiais do verbo, não exercendo o papel de qualificadores. Excluindo, portanto, os casos identificados como estado e também os erros, obtemos 5262 predicações, das quais 2937 (56\%) caracterizam personagens masculinos e 2325 (44\%) descrevem personagens femininos. Apesar de a maioria dos predicadores (lemas) encontrados para ambos os gêneros ser designadora de caráter ou personalidade, como vimos na análise da variedade lexical, a distribuição dos gráficos 2 e 3 não leva em conta a frequência com que cada predicação acontece associada a um gênero. Quando esses números são considerados, distribuição se altera, como vemos nas figuras 4 e 5 - há lemas que aparecem muitas vezes no corpus, como bonito e sério, conforme já explicamos em 3.3.1. 


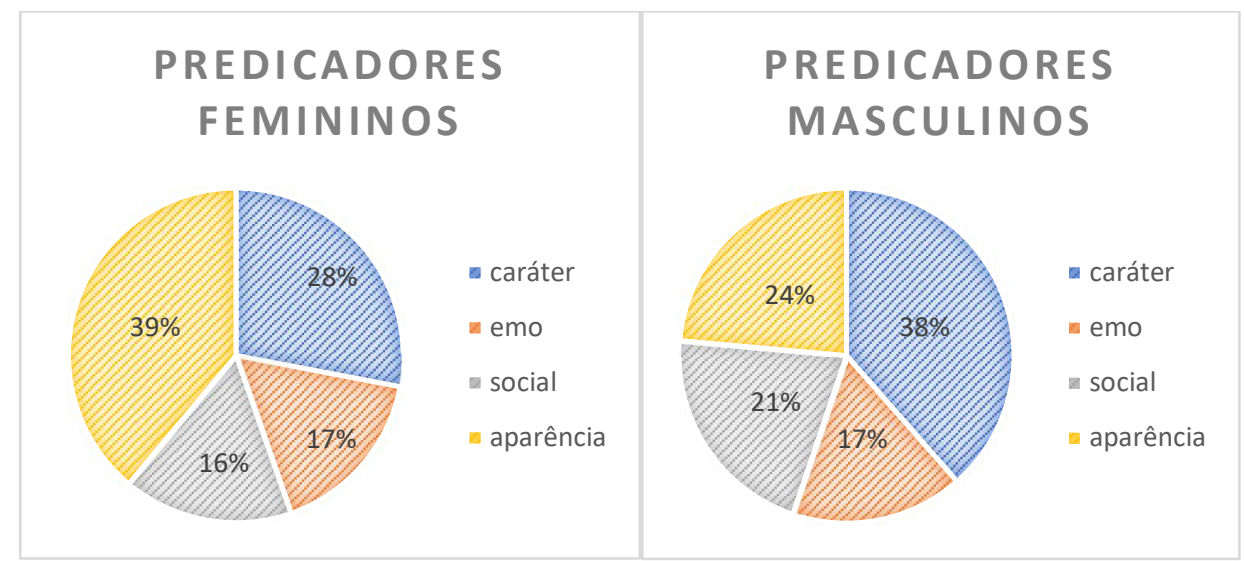

Gráficos 6 e 7 - Distribuição dos predicadores quanto ao gênero, pelas categorias semânticas, considerando o número de vezes que cada um ocorre, excluindo erros e a categoria estado.

Deste ponto de vista, cerca de $40 \%$ das predicações são femininas relacionadas a características físicas ou de aparência, e cerca de $40 \%$ das masculinas, a cárater e personalidade. Emoções são expressas em 16 a $17 \%$ das predicações do corpus, para os dois gêneros. A figura abaixo mostra uma "nuvem de palavras" (wordcloud) e ilustra como se destacam os predicadores mais frequentes em cada um dos gêneros. Entre os predicadores femininos, "bonita" aparece em proporção muito maior do que o segundo predicador feminino mais comum, "bela", e também do que o predicador masculino mais frequente, "sério".
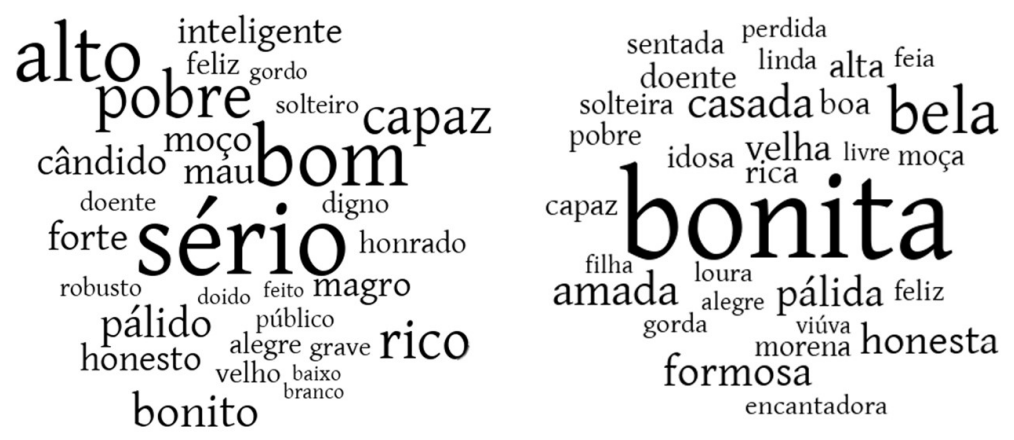

Figura 2 - Nuvem de palavras criada com os 30 predicadores de maior ocorrência para cada gênero. $O$ tamanho das palavras é proporcional ao número de vezes que o predicador ocorre. 
Desta vez, iremos observar os predicadores que ocorrem para os dois gêneros, fazendo um comparativo de preferência, com base na proporção em que ocorrem para cada um deles. O que decidimos aqui chamar de "preferência" é um fator comparativo de proporção entre a quantidade de vezes em que cada predicador ocorre para cada gênero, em relação ao total de ocorrências desse predicador. Tomemos como exemplo o predicador "belo". Belo ocorre 71 vezes em nosso corpus, sendo 66 vezes para caracterização de personagens femininas, o que corresponde a 93\% do total de ocorrências desse predicador no corpus. Apenas em 7\% das ocorrências, "belo" aparece enquanto predicação masculina. Isto faz com que "belo" seja preferencialmente utilizado para predicações de personagens femininas. No quadro a seguir, vemos os trinta predicadores comuns aos dois gêneros, em ordem de preferência por gênero. 


\begin{tabular}{|l|r|l|l|l|r||}
\hline \multicolumn{5}{|c|}{ Preferência feninina } \\
\hline \hline predicador & fen & $\%$ & masc & $\%$ & total \\
\hline belo & 66 & $93 \%$ & 5 & $7 \%$ & 71 \\
\hline assustado & 8 & $89 \%$ & 1 & $11 \%$ & 9 \\
\hline idoso & 22 & $88 \%$ & 3 & $12 \%$ & 25 \\
\hline fácil & 5 & $83 \%$ & 1 & $17 \%$ & 6 \\
\hline viúvo & 14 & $82 \%$ & 3 & $18 \%$ & 17 \\
\hline ajoelhado & 9 & $82 \%$ & 2 & $18 \%$ & 11 \\
\hline amado & 43 & $81 \%$ & 10 & $19 \%$ & 53 \\
\hline bonito & 146 & $81 \%$ & 34 & $19 \%$ & 180 \\
\hline agradável & 4 & $80 \%$ & 1 & $20 \%$ & 5 \\
\hline medroso & 4 & $80 \%$ & 1 & $20 \%$ & 5 \\
\hline convencido & 4 & $80 \%$ & 1 & $20 \%$ & 5 \\
\hline agitado & 4 & $80 \%$ & 1 & $20 \%$ & 5 \\
\hline mudo & 4 & $80 \%$ & 1 & $20 \%$ & 5 \\
\hline travesso & 11 & $79 \%$ & 3 & $21 \%$ & 14 \\
\hline amante & 7 & $78 \%$ & 2 & $22 \%$ & 9 \\
\hline infeliz & 7 & $78 \%$ & 2 & $22 \%$ & 9 \\
\hline feio & 17 & $77 \%$ & 5 & $23 \%$ & 22 \\
\hline contentissimo & 3 & $75 \%$ & 1 & $25 \%$ & 4 \\
\hline corado & 3 & $75 \%$ & 1 & $25 \%$ & 4 \\
\hline guerreiro & 3 & $75 \%$ & 1 & $25 \%$ & 4 \\
\hline gracioso & 3 & $75 \%$ & 1 & $25 \%$ & 4 \\
\hline apático & 3 & $75 \%$ & 1 & $25 \%$ & 4 \\
\hline à-toa & 3 & $75 \%$ & 1 & $25 \%$ & 4 \\
\hline casado & 43 & $73 \%$ & 16 & $27 \%$ & 59 \\
\hline moreno & 21 & $72 \%$ & 8 & $28 \%$ & 29 \\
\hline aflito & 5 & $71 \%$ & 2 & $29 \%$ & 7 \\
\hline fresco & 5 & $71 \%$ & 2 & $29 \%$ & 7 \\
\hline azul & 5 & $71 \%$ & 2 & $29 \%$ & 7 \\
\hline caprichoso & 9 & $69 \%$ & 4 & $31 \%$ & 13 \\
\hline perdido & 18 & $67 \%$ & 9 & $33 \%$ & 27 \\
\hline
\end{tabular}

\begin{tabular}{|l|r|r|r|r|r||}
\hline \multicolumn{5}{|c|}{ Preferência masculina } \\
\hline \hline predicador & fen & \multicolumn{1}{|c|}{$\%$} & masc & \multicolumn{1}{|l|}{$\%$} & tołal \\
\hline mau & 2 & $6 \%$ & 29 & $94 \%$ & 31 \\
\hline grave & 2 & $9 \%$ & 21 & $91 \%$ & 23 \\
\hline cândido & 3 & $9 \%$ & 29 & $91 \%$ & 32 \\
\hline sério & 8 & $10 \%$ & 74 & $90 \%$ & 82 \\
\hline prático & 1 & $10 \%$ & 9 & $90 \%$ & 10 \\
\hline desconhecido & 1 & $10 \%$ & 9 & $90 \%$ & 10 \\
\hline absoluto & 1 & $10 \%$ & 9 & $90 \%$ & 10 \\
\hline civilizado & 1 & $13 \%$ & 7 & $88 \%$ & 8 \\
\hline sertanejo & 1 & $13 \%$ & 7 & $88 \%$ & 8 \\
\hline teimoso & 1 & $13 \%$ & 7 & $88 \%$ & 8 \\
\hline resoluto & 1 & $13 \%$ & 7 & $88 \%$ & 8 \\
\hline robusto & 3 & $13 \%$ & 20 & $87 \%$ & 23 \\
\hline contente & 2 & $14 \%$ & 12 & $86 \%$ & 14 \\
\hline ilustrado & 1 & $14 \%$ & 6 & $86 \%$ & 7 \\
\hline admirável & 1 & $14 \%$ & 6 & $86 \%$ & 7 \\
\hline ativo & 1 & $14 \%$ & 6 & $86 \%$ & 7 \\
\hline respeitável & 2 & $15 \%$ & 11 & $85 \%$ & 13 \\
\hline calmo & 2 & $17 \%$ & 10 & $83 \%$ & 12 \\
\hline abastado & 1 & $17 \%$ & 5 & $83 \%$ & 6 \\
\hline útil & 1 & $17 \%$ & 5 & $83 \%$ & 6 \\
\hline sisudo & 1 & $17 \%$ & 5 & $83 \%$ & 6 \\
\hline ébrio & 1 & $17 \%$ & 5 & $83 \%$ & 6 \\
\hline cruel & 1 & $17 \%$ & 5 & $83 \%$ & 6 \\
\hline perigoso & 1 & $17 \%$ & 5 & $83 \%$ & 6 \\
\hline namorado & 1 & $17 \%$ & 5 & $83 \%$ & 6 \\
\hline limpo & 1 & $17 \%$ & 5 & $83 \%$ & 6 \\
\hline único & 1 & $17 \%$ & 5 & $83 \%$ & 6 \\
\hline brutal & 1 & $17 \%$ & 5 & $83 \%$ & 6 \\
\hline inteligente & 6 & $18 \%$ & 27 & $82 \%$ & 33 \\
\hline doido & 4 & $18 \%$ & 18 & $82 \%$ & 22 \\
\hline
\end{tabular}

Tabela 5 - Lista dos predicadores comuns aos dois gêneros mais frequentes, listados por preferência.

No exemplo dado no parágrafo anterior, explicamos por que motivo identificamos "belo" como sendo preferencialmente feminino. Fizemos o cálculo da proporção (percentagem) em que cada um desses predicadores ocorre para cada um dos gêneros, e em seguida ordenamos a lista em forma decrescente para cada um dos gêneros, de forma a obter a lista dos predicadores mais preferencialmente femininos e dos preferencialmente mais masculinos. De agora em diante, nos referiremos a eles como sendo "os mais femininos" e "os mais masculinos", para simplificação da escrita. 
Observando o quadro, percebemos que o predicador mais feminino de nossa lista é "belo", coincidentemente, um sinônimo do predicador mais ocorrente dentre todos os encontratos para personagens femininas, "bonito", e portanto também fazendo parte do eixo aparência. Também identificamos que elas são mais caracterizadas como medrosas (80\%), infelizes (78\%) e assustadas (89\%) e idosas (88\%) do que eles. Já eles costumam ser mais sérios $(90 \%)$, absolutos ${ }^{30}(90 \%)$, resolutos $(88 \%)$, robustos $(87 \%)$, teimosos $(88 \%)$.

É óbvio que a beleza não seja apenas associada à aparência física; entretanto, nos contextos em que ocorre, a beleza geralmente é apresentada como algo que se percebe, algo que se aparenta, como podemos perceber observando os excertos linhas de concordância que se seguem para a busca ${ }^{31}$ feita pelo lema "belo", em contexto de predicação feminina e masculina:

id="A_Mortalha_de_Alzira Prosa:romance AA 1894 naturalismo_realismo_romantismo masc ": Mas onde incontestavelmente o assunto despertou maior escândalo, foi no salão da condessa Alzira, bela, cínica e espirituosa cortesã, célebre por ser nessa época a mulher mais insensível e mais fria de Paris .

$i d=" O \_$Mulato Prosa:romance AA 1881 naturalismo masc ": Meio deitada nas pernas dele, cingindo-lhe a cintura, uma mulher bela, o colo nu e fresco, a garganta lisa e carnuda, procurava, com o olhar muito mole de uma ternura úmida e escrava, diminuir-lhe a cólera .

id="Uma_lágrima_de_mulher Prosa:romance AA 1879 romantismo masc ":

Como em quase todas as meninas italianas, adivinhavam-se-lhe os elementos de uma mulher bela .

id="Uma_lágrima_de_mulher Prosa:romance AA 1879 romantismo masc ": Viver na grande capital, com opulência, beleza, mocidade, saúde, alegria, admiradores; isto é, realizar o mais dourado dos sonhos, a mais sonhada das esperanças, o desejo mais querido e a mais brilhante expectativa do coração de uma mulher bela e vaidosa .

id="Uma_lágrima_de_mulher Prosa:romance AA 1879 romantismo masc ":

Rosalina soltou um grito horrorizada, grito igual ao da cotovia ao sentir a bala do caçador, e caiu sem sentidos nos braços de Miguel, que imóvel, hirto, chumbado

\footnotetext{
30 Presente nas expressões "senhor absoluto" e "senhora absoluta".

31 As expressões de busca utilizadas estão no Apêndice 2.
} 
à terra, parecia uma estátua de bronze, tendo nos braços uma mulher bela $\mathrm{e}$ pálida, de uma beleza e de uma palidez de mármore .

id="Uma_lágrima_de_mulher Prosa:romance AA 1879 romantismo masc ": Rosalina, bela, mas já dessa beleza satânica das bacanais -- pendente a cabeça, requebrando o olhar e o colo nu, valsava no salão principal com um rapaz de bigodes pretos, reclinada voluptuosamente sobre ele, entregues ambos ao desamparo, feliz e enebriante do prazer e da fadiga .

id="Dentro_da_Noite Prosa:contos JdR 1910 masc ": Maria tinha carruagens, elétrico, arrastava à noite pelos pequenos teatros maravilhosas capas de peles de muitos bilhetes de mil, e frequentava vários lugares maus porque vendo-a um dia a pé a rodar um bistrô, lembrei-me que bem podia estar de paixão por algum jovem apache, que os apaches são os homens belos de Paris .

id="O_moço_louro Prosa:romance JMdM 1845 romantismo masc ": Passada uma hora, o náufrago sentiu-se abrasado por terrível febre... houve um momento em que teve medo de morrer... pediu um padre, e não achou quem o fosse chamar; e então ele, jovem, belo, rico, caiu de joelhos aos pés de uma mulher morfética e arrasou um segredo infame! ...

id="O_moço_louro Prosa:romance JMdM 1845 romantismo masc ": Esse menino era belo, alegre e esperto, e mostrava-se, então, abatido e melancólico.

$i d=$ "Os_Dois_Amores Prosa:romance JMdM 1848 romantismo masc ": Era um homem alto e belo; seus olhos pretos lançavam olhares brandos que condiziam perfeitamente com o sorrir meigo e um pouco melancólico de seus lábios .

id="Os_Dois_Amores Prosa:romance JMdM 1848 romantismo masc ": Depois vinha um menino louro, travesso e belo brincar a seu lado... então ela se lembrava! ... e essa lembrança era terrível; era um punhal de lâmina envenenada... era o castigo de Deus .

id="Curta_história Prosa:conto MdA 1886 masc ": Entrou Romeu, elegante e belo, e toda ela comoveu-se; viu depois entrar a divina Julieta, mas as cenas eram diferentes, os dois não se falavam logo; ouviu-os, porém, falar no baile de máscaras, adivinhou o que sabia, bebeu de longe as palavras eternamente belas, que iam cair dos lábios de ambos.

Associando as preferências por gênero aos eixos, vemos que as predicações preferencialmente femininas são do tipo emoção e aparência, e as predicações preferencialmente masculinas dizem respeito ao caráter e ao papel social, em um quadro diferente daquele que apresenta as predicações por eixo sem levar em conta as preferências. 


\begin{tabular}{|c|c|c|c|c|c|c|c|}
\hline \multicolumn{4}{|c|}{ Preferência feminina } & \multicolumn{4}{|c|}{ Preferência masculina } \\
\hline predicador & eixo & fem & $\%$ & predicador & eixo & masc & $\%$ \\
\hline belo & aparência & 66 & $93 \%$ & mau & caráter & 29 & $94 \%$ \\
\hline assustado & emo & 8 & $89 \%$ & grave & caráter & 21 & $91 \%$ \\
\hline idoso & aparência & 22 & $88 \%$ & cândido & caráter & 29 & $91 \%$ \\
\hline viúvo & social & 21 & $88 \%$ & sério & caráter & 74 & $90 \%$ \\
\hline fácil & caráter & 5 & $83 \%$ & prático & estado & 9 & $90 \%$ \\
\hline ajoelhado & estado & 9 & $82 \%$ & desconhecido & social & 9 & $90 \%$ \\
\hline amado & emo & 43 & $81 \%$ & absoluto & caráter & 9 & $90 \%$ \\
\hline bonito & aparência & 146 & $81 \%$ & civilizado & social & 7 & $88 \%$ \\
\hline agradável & emo & 4 & $80 \%$ & sertanejo & social & 7 & $88 \%$ \\
\hline medroso & emo & 4 & $80 \%$ & teimoso & caráter & 7 & $88 \%$ \\
\hline convencido & emo & 4 & $80 \%$ & resoluto & estado & 7 & $88 \%$ \\
\hline agitado & emo & 4 & $80 \%$ & robusto & aparência & 20 & $87 \%$ \\
\hline mudo & aparência & 4 & $80 \%$ & contente & emo & 12 & $86 \%$ \\
\hline travesso & caráter & 11 & $79 \%$ & ilustrado & social & 6 & $86 \%$ \\
\hline amante & social & 7 & $78 \%$ & admirável & emo & 6 & $86 \%$ \\
\hline infeliz & emo & 7 & $78 \%$ & ativo & social & 6 & $86 \%$ \\
\hline feio & aparência & 17 & $77 \%$ & respeitável & emo & 11 & $85 \%$ \\
\hline contentíssimo & emo & 3 & $75 \%$ & calmo & caráter & 10 & $83 \%$ \\
\hline corado & emo & 3 & $75 \%$ & abastado & social & 5 & $83 \%$ \\
\hline guerreiro & social & 3 & $75 \%$ & útil & caráter & 5 & $83 \%$ \\
\hline
\end{tabular}

Tabela 6 - Lista dos vinte predicadores comuns aos dois gêneros mais frequentes, listados por preferência, com indicação do eixo semântico.

Uma pergunta que ouvimos bastante durante esta pesquisa foi sobre a distribuição nas obras de autoria feminina, e quais os predicadores mais frequentes. Como nosso corpus contem apenas 3 obras escritas por mulheres, não é possível fazer uma comparação justa. Mas iremos mostrar a seguir, dentre as obras de autoria feminina do corpus, a distribuição dos predicadores pelos quatro eixos semânticos.

Utilizando as mesmas expressões de busca, encontramos, nas três obras, 114 lemas diferentes de predicadores femininos e 97 masculinos. Os gráficos abaixo mostram a distribuição por cada um dos cinco eixos. 

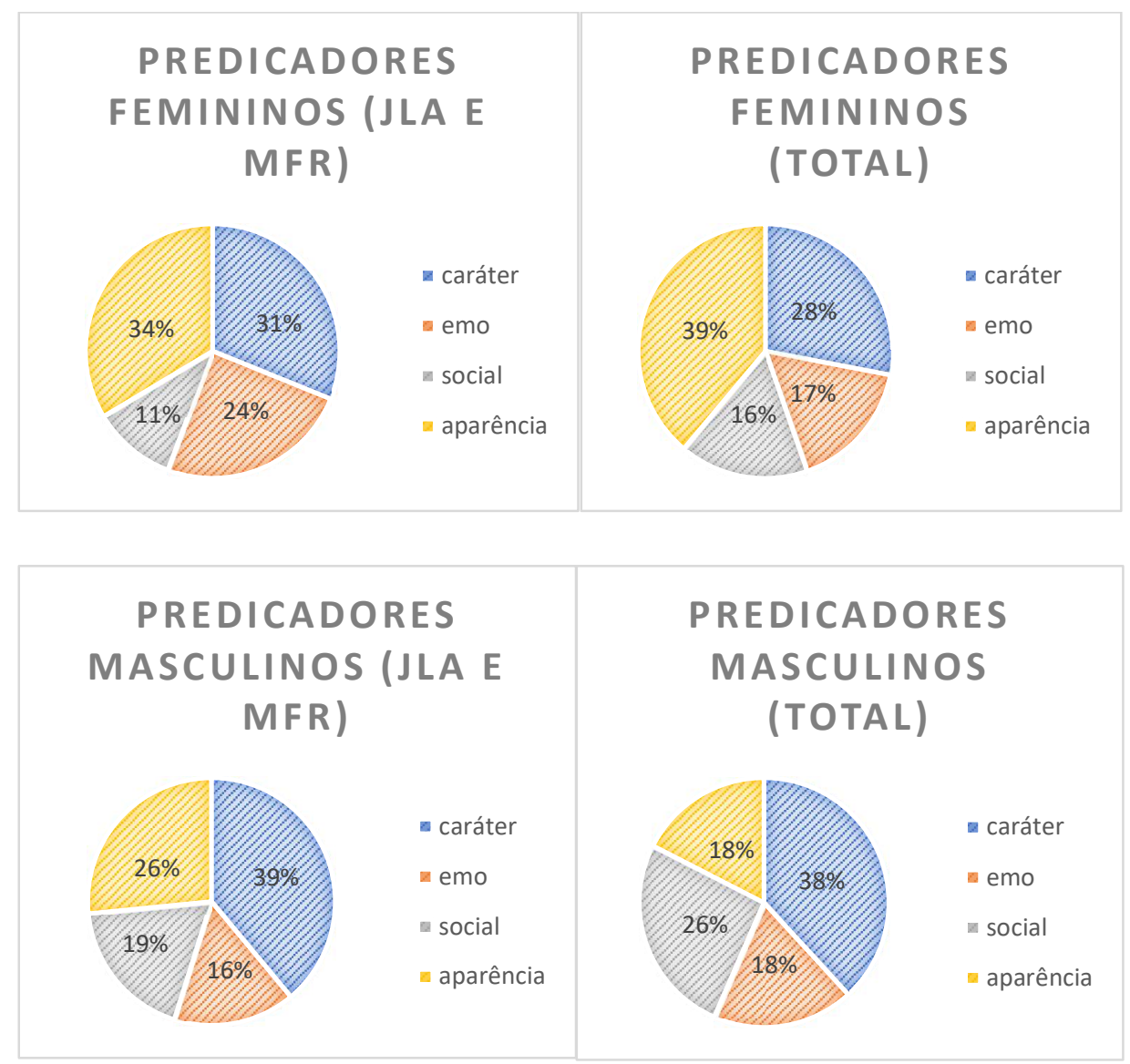

Gráficos 8 e 9 - Distribuição dos predicadores quanto ao gênero, pelas quatro categorias semânticas, considerando o número de ocorrências, nas obras de Júlia Lopes de Almeida e Maria Firmina dos Reis que fazem parte do corpus. Repetimos os gráficos 6 e 7 para comparação.

Personagens masculinos são, tal como observado na totalidade do corpus, predominantemente descritos pelo caráter e personalidade; porém observa-se um maior equilíbrio entre corpo e caráter para descrição de personagens femininos em relação ao total de obras. Há menos caracterizações do eixo lugar social (19\%) e mais emoções $(26 \%)$ para personagens masculinos nas obras das duas autoras em relação à distubuição pelos eixos no total das obras: $26 \%$ para lugar social e $18 \%$ para emoção e sentimento. Entre os femininos, vemos mais destaque para emoções (24\%) em relação ao total (17\%) e menos predicadores no eixo lugar social (11\%) em relação ao total (16\%). Passamos, em seguida, à análise das preferências nas obras de autoria feminina do nosso corpus. 


\begin{tabular}{|c|c|c|c|c|c|c|c|}
\hline \multicolumn{8}{|c|}{ Preferência } \\
\hline predicador & qtd $F$ & & $\%$ & qtd M & & $\%$ & total \\
\hline bonito & & 5 & $50 \%$ & & 5 & $50 \%$ & 10 \\
\hline moço & & 3 & $60 \%$ & & 2 & $40 \%$ & 5 \\
\hline atônito & & 2 & $67 \%$ & & 1 & $33 \%$ & 3 \\
\hline cego & & 2 & $67 \%$ & & 1 & $33 \%$ & 3 \\
\hline capaz & & 2 & $67 \%$ & & 1 & $33 \%$ & 3 \\
\hline bom & & 2 & $25 \%$ & & 6 & $75 \%$ & 8 \\
\hline ausente & & 1 & $50 \%$ & & 1 & $50 \%$ & 2 \\
\hline orgulhoso & & 1 & $50 \%$ & & 1 & $50 \%$ & 2 \\
\hline moreno & & 1 & $50 \%$ & & 1 & $50 \%$ & 2 \\
\hline enfermo & & 1 & $50 \%$ & & 1 & $50 \%$ & 2 \\
\hline gordo & & 1 & $50 \%$ & & 1 & $50 \%$ & 2 \\
\hline rico & & 1 & $25 \%$ & & 3 & $75 \%$ & 4 \\
\hline delicado & & 1 & $50 \%$ & & 1 & $50 \%$ & 2 \\
\hline honesto & & 1 & $50 \%$ & & 1 & $50 \%$ & 2 \\
\hline criança & & 1 & $50 \%$ & & 1 & $50 \%$ & 2 \\
\hline íntimo & & 1 & $50 \%$ & & 1 & $50 \%$ & 2 \\
\hline velho & & 1 & $33 \%$ & & 2 & $67 \%$ & 3 \\
\hline novo & & 1 & $33 \%$ & & 2 & $67 \%$ & 3 \\
\hline magro & & 1 & $50 \%$ & & 1 & $50 \%$ & 2 \\
\hline
\end{tabular}

Tabela 7 - Lista dos predicadores comuns aos dois gêneros e seus índices de preferência, nas obras de Júlia Lopes de Almeida e Maria Firmina dos Reis.

\begin{tabular}{|c|c|c|}
\hline \multicolumn{3}{|c|}{ Exclusivos femininos } \\
\hline predicador & qtd & eixo \\
\hline infame & 4 & caráter \\
\hline pobre & 4 & social \\
\hline formoso & 3 & aparência \\
\hline tímido & 2 & caráter \\
\hline radiante & 2 & emo \\
\hline ingênuo & 2 & caráter \\
\hline trêmulo & 2 & aparência \\
\hline angélico & 2 & caráter \\
\hline moça & 2 & aparência \\
\hline belo & 2 & aparência \\
\hline
\end{tabular}

\begin{tabular}{||l||ll||}
\hline \multicolumn{3}{|c||}{ Exclusivos masculinos } \\
\hline \hline predicador & qtd & eixo \\
\hline desapiedado & 3 & caráter \\
marítimo & 3 & social \\
generoso & 3 & caráter \\
mau & 3 & caráter \\
loiro & 2 & corpo \\
capelão & 2 & social \\
miúdo & 2 & aparência \\
honrado & 2 & caráter \\
feroz & 2 & emo \\
grande & 2 & caráter
\end{tabular}

Tabela 8 - Lista dos predicadores exclusivos a cada gêneros, com mais de uma ocorrência, nas obras de Júlia Lopes de Almeida e Maria Firmina dos Reis. 
A ocorrência dos predicadores é bastante equilibrada entre os dois gêneros: metade dos predicadores comuns aparece para os dois gêneros em frequência equivalente (50\%). Com $67 \%$ cada, os predicadores preferencialmente femininos são "atônito", "cego" e "capaz". Destacam-se "bom" e "rico" (75\% cada) como preferencialmente masculinos, seguidos por "velho" e "novo", como $67 \%$ cada.

É possível que os homens sejam tão mais frequentemente descritos por sua beleza nestas obras, do que no nas demais obras deste corpus, por serem palavras escritas por mãos femininas? Não dispomos ainda de material suficiente para fazer uma comparação mais significativa, mas é interessante observar que a tendência da distribuição pelos eixos seja parecida com a do total de predicadores no corpus: predicadores femininos mais comuns relacionados a aparência e masculinos a caráter/personalidade, embora vejamos um maior número de caracterizações pela aparência de personagens masculinos e de caráter para femininos do que no total das obras. Sobre se as autoras do século XIX seriam ou não feministas, Muzart (1999, apud Duarte, 2019) defende que sim, "pois só o desejo de sair do fechamento doméstico já indicava uma cabeça pensante e um desejo de subversão", portanto "a literatura feminina no Brasil esteve ligada sempre a um feminismo incipiente."

Antes de desenvolvermos uma consciência feminista, também nós, mulheres, reproduzimos a assimetria social de gênero, pois, tal como Hooks (2019) constata, a maioria de nós foi socializada por pais e mães e pela sociedade para aceitar pensamentos sexistas", e atenta para os momentos em que, se deixamos de ser "críticos e atentos", o sexismo volta a se manifestar, porque o senso comum nos apresenta a diferença como a norma, a ordem natural das coisas.

\subsection{Ações}

Quando decidimos analisar as ações que os personagens executam, pensamos em, assim como fizemos com predicadores, ver se seria possível 
separá-los em eixos semânticos. Diferentemente dos predicadores, a maioria dos verbos que encontramos tem seu sentido determinado pelos seus complementos. Verbos são altamente polissêmicos (Costa e Freitas, 2019); por este motivo, a categorização semântica não foi tão clara. Por exemplo, se chorar ou sorrir, verbos intransitivos, possibilitam um entendimento sem a necessidade de contextos mais amplos, o mesmo não pode ser dito de verbos como ganhar ou exercer, que podem assumir diferentes feições conforme o que se ganha e o que se exerce. Uma categorização dos verbos de nosso corpus demandaria dedicação exclusiva, um trabalho próprio, que desejamos desenvolver posteriormente.

Após realizar uma busca utilizando as expressões indicadas em 3.4, concatenadas, como se vê no Apêndice 6, obtivemos as listas de frequência por gênero. O AC/DC limita os resultados a 1000 entradas únicas na busca por lema, e assim obtivemos 1000 verbos associados a personagens, para cada gênero. A lista completa está disponível para consulta no Apêndice 6. A tabela a seguir apresenta as informações relativas a esses verbos:

\begin{tabular}{|l|c|c|}
\hline & $\begin{array}{c}\text { Quantidade } \\
\text { de Lemas } \\
\text { distintos }\end{array}$ & $\begin{array}{c}\text { Total de } \\
\text { ocorrências }\end{array}$ \\
\hline $\begin{array}{l}\text { Verbos associados exclusivamente a personagens } \\
\text { femininas }\end{array}$ & 355 & 499 \\
\hline $\begin{array}{l}\text { Verbos associados exclusivamente a personagens } \\
\text { masculinas }\end{array}$ & 355 & 913 \\
\hline Verbos associados a ambos & 645 & 24876 \\
\hline Total de verbos associados a personagens & 1355 & 26288 \\
\hline
\end{tabular}

Tabela 9 - Contagem dos verbos designadores de ação executada por personagens no corpo OBras. 
A lista de distribuição traz, em sua maioria, verbos leves ${ }^{32}$, algo que poderíamos entender como esperado, pois estes verbos são muito comuns e servem de suporte a inúmeras expressões verbais na língua portuguesa.

\begin{tabular}{lrlr} 
Verbo & \multicolumn{2}{c}{ Masculinos } \\
ter & qtd & Verbo & qtd \\
ficar & 537 & ter & 825 \\
fazer & 279 & fazer & 487 \\
querer & 272 & ficar & 378 \\
dar & 197 & querer & 342 \\
dizer & 178 & dar & 292 \\
entrar & 167 & entrar & 276 \\
olhar & 160 & sair & 272 \\
sorrir & 156 & dizer & 243 \\
ir & 153 & ver & 241 \\
voltar & 146 & ir & 226 \\
sentir & 139 & olhar & 211 \\
saber & 138 & voltar & 200 \\
ouvir & 111 & vir & 197 \\
sair & 109 & sentir & 194 \\
ver & 107 & chegar & 192 \\
falar & 101 & saber & 184 \\
vir & 99 & falar & 184 \\
estremecer & 98 & passar & 164 \\
passar & 92 & sorrir & 160 \\
& 90 & tomar & 158 \\
- Lista dos verbos leves & & & \\
& & &
\end{tabular}

Não é possível determinar o sentido desses verbos sem olharmos para seus complementos: ter, ficar, fazer, querer, dar, dizer, sair, entrar. Alguns exemplos ilustram bem a vagueza desses verbos, se tomados isoladamente, sendo seu complemento essencial para definição de sentido. Tomemos como exemplo o verbo dar:

id="Um_almoço Prosa:conto MdA 1877masc ": Elvira deu pela vítima antes mesmo que esta desse por si.

32 Verbos leves, ou verbos-suporte, "são verbos de significado bastante esvaziado que formam, com seu complemento (objeto direto), um significado global, geralmente correspondente ao que tem um outro verbo da língua." (Neves, 2001 apud Bagno, 2012). 
id="A_falência Prosa:romance JLdA 1901 naturalismo_realismo fem ": Nina ia passar por cima dela, quando Noca deu um grito.

id="O_Mulato Prosa:romance AA 1881 naturalismo masc ": Mas, do vão escuro, em que se formava 0 limite da parede, rebentou um tiro, no momento em que ele dava volta à chave.

id="Ressurreição Prosa:romance MdA 1872 romantismo masc ": Félix deu o braço a Viana .

id="Dentro_da_Noite Prosa:contos JdR 1910 masc ": É mesmo provável que tivessem deixado Paris, quando já Maria dava uns chás a alguns vagos titulares internacionais, por algum de escândalo, que o Azevedo teve de saber e pagar.

id="A_afilhada Prosa:novela MdOP 1899 naturalismo masc ": Ele deu fé e gritou:

id="laiá_Garcia Prosa:romance MdA 1878 romantismo masc ": Uma noite, tendo Luís Garcia adormecido, Estela deu a perceber à enteada que o estado do pai era grave.

id="Cinco_mulheres Prosa:conto MdA 1865 masc ": Lúcia deu ordem para que não recebesse cartas que viessem pelo mesmo portador .

id="Felicidade_pelo_casamento Prosa:conto MdA 1866 masc ": Quando Ângela deu parte de pronta, despedimo-nos e o doutor ofereceu a casa ao namorado, mas com uma fria polidez.

id="Helena Prosa:romance MdA 1876 romantismo masc ": Helena deu entrada em um colégio de Botafogo, onde recebeu apurada educação .

id="O_pai Prosa:conto MdA 1866 masc ": Emília deu conta a seu pai dos projetos de Valentim

Diante destes resultados, tomados aqui apenas como ilustração dos verbos leves, surge aqui mais uma possibilidade de trabalho interessante a 
se desenvolver posteriormente, utilizando as nossas expressões de busca, que seria sobre as expressões multi-palavras verbais no corpus.

Como vimos na tabela 10 , e também se observa no apêndice 6 , embora a maioria dos verbos ocorra para os dois gêneros, há muitos que aparecem apenas como ações de personagens de determinado gênero. Também é de se imaginar que haja preferências, dentre os comuns aos dois, do mesmo modo que observamos para os predicadores. A tabela a seguir apresenta uma seleção dos verbos mais frequentes, para designar ações de personagens de apenas um dos gêneros.

\begin{tabular}{lrlr}
\multicolumn{2}{c}{ Exclusivos femininos } & \multicolumn{2}{c}{ Exclusivos masculinos } \\
verbo & qtd & verbos & qtd \\
cogitar & 5 & montar & 12 \\
verter & 5 & fumar & 11 \\
alimentar & 5 & obter & 11 \\
ostentar & 4 & marcar & 10 \\
ressonar & 4 & depositar & 9 \\
enrolar & 4 & coçar & 9 \\
enrubescer & 4 & travar & 9 \\
agonizar & 4 & discutir & 9 \\
amamentar & 4 & desistir & 8 \\
talhar & 4 & construir & 8 \\
definhar & 4 & roubar & 8 \\
derrear & 3 & governar & 8 \\
instar & 3 & impor & 7 \\
ansiar & 3 & combater & 7 \\
saudar & 3 & plantar & 7 \\
elevar & 3 & determinar & 7 \\
repassar & 3 & rejeitar & 7 \\
dignar & 3 & demonstrar & 6 \\
obtemperar & 3 & regressar & 6 \\
cavalgar & 3 & salvar & 6 \\
rodar & 3 & empurrar & 6 \\
renunciar & 3 & atalhar & 6 \\
tapar & 3 & respeitar & 6 \\
dissimular & 3 & aconselhar & 6 \\
enfeitar & 3 & velar & 6 \\
arfar & 3 & depor & 6 \\
reprovar & 3 & galgar & 6 \\
proteger & 3 & bastar & 6
\end{tabular}

Tabela 11 - Verbos exclusivos para personagens femininos e masculinos, por ordem de frequência. 
Em nossas buscas, percebemos que somente eles montam e apenas elas cavalgam. Vejamos os contextos:

Cavalgar:

id="Recordações_do_escrivão_Isaías_Caminha Prosa:romance LB 1909 realismo masc ": Em torno da mesa, uma mulher cavalgava uma espécie de tapir ou de anta .

id="Helena Prosa:romance MdA 1876 romantismo masc ": Quando chegou à porta da cavalariça, viu aparelhados dois animais, o cavalo de seus passeios da manhã, e a égua que a tia cavalgava uma ou outra vez .

id="Helena Prosa:romance MdA 1876 romantismo masc ": Helena cavalgava perfeitamente; de quando em quando a égua, instigada por ela, adiantava-se alguns passos ao cavalo; Estácio repreendia a irmã, a seu pesar, porque ao mesmo tempo que temia alguma imprudência, gostava de Ihe ver o airoso do busto e a firme serenidade com que ela conduzia o animal.

Montar:

id="A_Escrava_Isaura Prosa:romance BG 1875 romantismo masc ": Depois do almoço Leôncio montou a cavalo, percorreu as roças e cafezais, coisa que bem raras vezes fazia, e ao descambar do Sol voltou para casa, jantou com o maior sossego e apetite, e depois foi para o salão, onde, repoltreando-se em macio e fresco sofá, pôs-se a fumar tranqüilamente o seu havana .

id="O_seminarista Prosa:romance BG 1872 romantismo_regionalismo masc ": À tardinha desse mesmo dia, o rapaz montou a cavalo, e tomou o caminho da vila, mas lá não chegou .

id="O_gaúcho Prosa:romance JdA 1870 romantismo_regionalismo masc ": Pela primeira vez montou ele o soberbo ginete, e deu algumas voltas pelo campo. 
$\mathrm{O}$ ato de montar a cavalo e cavalgar poderiam soar de certa forma como adjacentes - montar o cavalo para cavalgar, ou até mesmo como sinônimos. Mas a escolha lexical pode ser mera coincidência, ou talvez não. "Montar" e "cavalgar" têm uma conotação erótica, que poderiam justificar a escolha lexical; o primeiro, associado à virilidade e poder - na pecuária, o termo "monta" designa o ato reprodutivo natural do gado; o segundo, em definição do dicionário Aulete Digital ${ }^{33}$ :

1. Sentar-se sobre o dorso de (cavalo) e viajar dessa forma, controlando a marcha do animal; montar (em); andar a cavalo.

2. Sentar sobre algo com as pernas abertas; montar ou deslocar-se sobre (algo, alguém), como em um cavalo.

O uso de montar, no lugar de cavalgar, atua como um eufemismo para "diluir", de certa forma, o ato de sentar-se sobre algo com as pernas abertas, inconveniente a um estereótipo de masculinidade; reservariam portanto, o "cavalgar" à fêmea.

Outras ações que são exclusivas dos homens no nosso corpus: determinar, demonstrar, governar, impor, combater, construir: ações que colocam os homens em posição de demonstração de poder; roubar e fumar também são ações apenas presentes entre eles. Das ações exclusivas das mulheres, vemos menear, verter, derrear, enrubescer, definhar, obtemperar, verbos que demonstram posição de submissão, timidez ou fraqueza; amamentar e alimentar, associados a atribuições familiares; ostentar, enfeitar e dissimular, associados a vaidade e futilidade. Estes verbos, escolhidos a dedo para caracterizar cada personagem, são um indício de que a literatura retrata a desigualdade existente nos papeis de gênero em nossa sociedade, e / ou ainda auxilia na criação / reforço / reprodução de estereótipos.

Dos verbos comuns aos dois gêneros, há 15324 ocorrências masculinas e 9552 femininas, que correspondem a uma proporção de $62 \%$ e $38 \%$. Para podermos comparar os comuns aos dois gêneros, voltamos

${ }^{33} \mathrm{http}: / / \mathrm{www}$.aulete.com.br/cavalgar 
nosso olhar para a análise das preferências. Para tal, dividimos o número de ocorrências para cada gênero pelo total de ocorrências de cada verbo. A tabela a seguir mostra os verbos em níveis de preferência para cada gênero.

\begin{tabular}{|c|c|c|c|c|c|c|c|c|c|c|c|}
\hline \multicolumn{6}{|c|}{ Preferência feminina } & \multicolumn{6}{|c|}{ Preferência masculina } \\
\hline verbos & masc & $\%$ & fem & $\%$ & total & verbos & masc & $\%$ & fem & $\%$ & total \\
\hline exercer & 3 & $19 \%$ & 13 & $81 \%$ & 16 & ganhar & 30 & $91 \%$ & 3 & $9 \%$ & 33 \\
\hline soluçar & 5 & $22 \%$ & 18 & $78 \%$ & 23 & espreitar & 9 & $90 \%$ & 1 & $10 \%$ & 10 \\
\hline coser & 2 & $25 \%$ & 6 & $75 \%$ & 8 & estabelecer & 9 & $90 \%$ & 1 & $10 \%$ & 10 \\
\hline atender & 2 & $25 \%$ & 6 & $75 \%$ & 8 & considerar & 16 & $89 \%$ & 2 & $11 \%$ & 18 \\
\hline suprir & 1 & $25 \%$ & 3 & $75 \%$ & 4 & suspeitar & 8 & $89 \%$ & 1 & $11 \%$ & 9 \\
\hline corar & 14 & $26 \%$ & 40 & $74 \%$ & 54 & piscar & 8 & $89 \%$ & 1 & $11 \%$ & 9 \\
\hline baixar & 10 & $26 \%$ & 28 & $74 \%$ & 38 & acender & 38 & $88 \%$ & 5 & $12 \%$ & 43 \\
\hline cobrir & 3 & $27 \%$ & 8 & $73 \%$ & 11 & expor & 15 & $88 \%$ & 2 & $12 \%$ & 17 \\
\hline derramar & 3 & $27 \%$ & 8 & $73 \%$ & 11 & agradecer & 49 & $88 \%$ & 7 & $13 \%$ & 56 \\
\hline enviuvar & 2 & $29 \%$ & 5 & $71 \%$ & 7 & suar & 7 & $88 \%$ & 1 & $13 \%$ & 8 \\
\hline despedir & 2 & $29 \%$ & 5 & $71 \%$ & 7 & visitar & 7 & $88 \%$ & 1 & $13 \%$ & 8 \\
\hline perdoar & 2 & $29 \%$ & 5 & $71 \%$ & 7 & penetrar & 19 & $86 \%$ & 3 & $14 \%$ & 22 \\
\hline cessar & 2 & $29 \%$ & 5 & $71 \%$ & 7 & comprar & 25 & $86 \%$ & 4 & $14 \%$ & 29 \\
\hline relancear & 3 & $30 \%$ & 7 & $70 \%$ & 10 & conseguir & 62 & $86 \%$ & 10 & $14 \%$ & 72 \\
\hline saborear & 3 & $30 \%$ & 7 & $70 \%$ & 10 & embarcar & 18 & $86 \%$ & 3 & $14 \%$ & 21 \\
\hline esconder & 7 & $30 \%$ & 16 & $70 \%$ & 23 & jogar & 18 & $86 \%$ & 3 & $14 \%$ & 21 \\
\hline recear & 5 & $31 \%$ & 11 & $69 \%$ & 16 & vender & 12 & $86 \%$ & 2 & $14 \%$ & 14 \\
\hline chorar & 35 & $32 \%$ & 74 & $68 \%$ & 109 & cortejar & 6 & $86 \%$ & 1 & $14 \%$ & 7 \\
\hline tocar & 17 & $33 \%$ & 34 & $67 \%$ & 51 & berrar & 6 & $86 \%$ & 1 & $14 \%$ & 7 \\
\hline desatar & 8 & $33 \%$ & 16 & $67 \%$ & 24 & tossir & 6 & $86 \%$ & 1 & $14 \%$ & 7 \\
\hline adoecer & 7 & $33 \%$ & 14 & $67 \%$ & 21 & entreabrir & 6 & $86 \%$ & 1 & $14 \%$ & 7 \\
\hline trajar & 5 & $33 \%$ & 10 & $67 \%$ & 15 & aproveitar & 41 & $85 \%$ & 7 & $15 \%$ & 48 \\
\hline rolar & 4 & $33 \%$ & 8 & $67 \%$ & 12 & atribuir & 17 & $85 \%$ & 3 & $15 \%$ & 20 \\
\hline lavar & 3 & $33 \%$ & 6 & $67 \%$ & 9 & cortar & 17 & $85 \%$ & 3 & $15 \%$ & 20 \\
\hline inspirar & 3 & $33 \%$ & 6 & $67 \%$ & 9 & resmungar & 17 & $85 \%$ & 3 & $15 \%$ & 20 \\
\hline invejar & 2 & $33 \%$ & 4 & $67 \%$ & 6 & suportar & 11 & $85 \%$ & 2 & $15 \%$ & 13 \\
\hline mover & 2 & $33 \%$ & 4 & $67 \%$ & 6 & pular & 16 & $84 \%$ & 3 & $16 \%$ & 19 \\
\hline cantarolar & 2 & $33 \%$ & 4 & $67 \%$ & 6 & acenar & 10 & $83 \%$ & 2 & $17 \%$ & 12 \\
\hline cheirar & 2 & $33 \%$ & 4 & $67 \%$ & 6 & campear & 5 & $83 \%$ & 1 & $17 \%$ & 6 \\
\hline revelar & 2 & $33 \%$ & 4 & $67 \%$ & 6 & atentar & 5 & $83 \%$ & 1 & $17 \%$ & 6 \\
\hline aquiescer & 1 & $33 \%$ & 2 & $67 \%$ & 3 & caçar & 5 & $83 \%$ & 1 & $17 \%$ & 6 \\
\hline
\end{tabular}

Tabela 12 - Lista dos verbos comuns aos dois gêneros listados por ordem de preferência (mostrando apenas os 30 mais frequentes para cada gênero). 
Do lado masculino, vemos ocupar a primeira posição o verbo "ganhar", com $91 \%$ das ocorrências totais. A seguir vemos os contextos em que ocorrem:

Femininos:

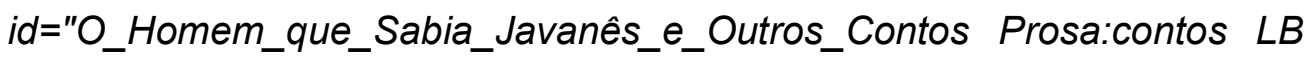
1997 masc ": Eles me embrulham e, se a senhora ganhar, a mim eles não pagam .

id="O_Homem_que_Sabia_Javanês_e_Outros_Contos Prosa:contos LB 1997 masc ": A senhora ganhou, menos no milhar e na centena .

id="Balas_de_estalo Prosa:crônica MdA 1883 masc ": Vá que o façamos nos dias em que eles, para acudir aos cochilos da agência Havas, transcrevem da Nación, de Buenos Aires, notícias telegráficas da vida política e internacional do mundo; mas como fazê-lo, quando, ainda há dias, a mesma agência nos comunicou este caso grave: ' Adelina Patti ganhou o processo de divórcio contra o seu marido, o Marquês de Caux ',

id="No_declínio Prosa:romance VdT 1889 romantismo_decadentismo masc ": A sua prima ganha muito em estar ao seu lado...

Masculinos:

id="A_Mortalha_de_Alzira_Prosa:romance AA 1894 naturalismo_realismo_romantismo masc ": E assim, no fim de alguns anos de arrependimento, Ozéas ganhara reputação de santo; e, com efeito, se nenhum religioso até antes fora mais culpado, nenhum também levou tão longe o esforço da sua reabilitação .

id="Dentro_da_Noite Prosa:contos JdR 1910 masc ": Esse homem ganhava rios de dinheiro, gozava de boas relações...

id="Os_Dois_Amores Prosa:romance JMdM 1848 romantismo masc ": Hoje não: estou velho... minhas juntas se acham enferrujadas... lutei com 
um mancebo, e ele ganhou a partida; mas agora também o caso é outro... não esqueço como dantes .

id="Clara_dos_anjos Prosa:romance LB 1948 naturalismo_realismo masc ": De dia para dia, ele ganhava mais fortemente a confiança da rapariga .id="Macunaíma Prosa:romance MdAndrade 1928 modernismo masc ": Macunaíma ganhou os bredos por outro lado e escapou .

id="A_semana Prosa:crônica MdA 1892 masc ": Os que ainda mamavam quando Osório ganhava a grande batalha, podem aplaudi-lo amanhã revivido no bronze, mas não terão o sentimento exato daqueles dias...

O que percebemos nas linhas de concordância, das quais extraímos os exemplos acima, os homens ganham reputação, partidas, rios de dinheiro e batalhas, enquanto as mulheres ganham na sorte, ou em estar ao lado de alguém, ou ganham o processo de divórcio, mais uma vez relegando-as ao ambiente familiar.

Já vimos que somente os homens fumam (tabela 11) e, por este motivo, acender é um verbo mais comum entre eles do que elas. Elas acendem velas e o gás ou um fogo em suas veias, enquanto eles, além destes, também acendem, candelabros, tochas, cigarros e charutos, como nos mostram os exemplos abaixo:

Masculinos:

id="Contos_fora_da_moda Prosa:conto ArtA 1894 masc ": Ele acendeu uma lamparina e apagou o gás .

id="Água_de_Juventa Prosa:contos CN 1905 realismo masc ": Eduardo acendeu um cigarro e, enquanto a mulher se revia ao espelho, recompondo os cabelos esvoaçantes, pôs-se a mirar as unhas, limpandoas, polindo-as com um pequenino estilete de prata .

id="Turbilhão Prosa:romance CN 1904 realismo masc ": Paulo acendeu o gás na sala de jantar e, chegando à porta da quarto, anunciou : 
id="Quem_não_quer_ser_lobo...Prosa:conto MdA 1872 masc ": Deu-lhe o charuto em que o homem acendeu o seu e prosseguiu viagem, sem voltar os olhos para trás ..

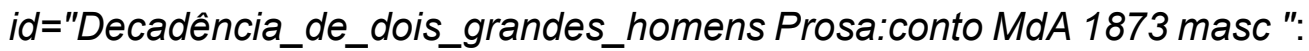
Jaime acendeu um lampião, enquanto eu me levantava para me ir embora.

id="Helena Prosa:romance MdA 1876 romantismo masc ": la anoitecendo; Estácio acendeu um candelabro .

id="Macunaíma Prosa:romance MdAndrade 1928 modernismo masc ": Maanape acendeu uma tocha de jutaí e puderam descer a escadinha negra .

Femininos:

id="O_Mulato Prosa:romance AA 1881 naturalismo masc ": Ana Rosa acendera uma vela a São Manuel do Buraco e Maria Bárbara prometera uma bochecha de cera a Santa Rita dos Milagres.

id="Romanceiro Prosa:contos CN 1898 realismo masc ": Quando o médico a declarou perdida as senhoras acenderam velas no oratório e rezaram para que Deus mandasse lágrimas à mísera como se fazem preces, nos campos, para que venham chuvas .

id="Turbilhão Prosa:romance CN 1904 realismo masc ": Ritinha acendeu uma vela e colocou-a à mesa de cabeceira, ao lado de um pequeno crucifixo.

id="O_monstro_e_outros_contos Prosa:conto HC 1932 masc ": Desde o momento em que o filho partiu, acendera ela uma lamparina de azeite em frente ao oratório tosco, forrado de azul, onde a Senhora das Dores chorava, o coração transpassado por uma espada.

id="Ubijarara Prosa:romance JdA 1874 indianismo_romantismo masc ": Ela acende em suas veias um fogo mais generoso que o do cauim, e prepara para seu corpo o repouso da cabana. 
id="A_falência Prosa:romance JLdA 1901 naturalismo_realismo fem ": Nina acendeu o gás, batendo os dentes, num acesso nervoso; depois contemplaram-se todos, em silêncio .

Além da exclusividade masculina para o ato de fumar, e portanto, de acender cigarros e afins, chama a atenção um único caso em que o "acender" feminino, não é a uma vela ou lampião, mas ao "generoso fogo" que "ela acende em suas veias", mais uma situação envolta pela sensualidade feminina. Não vemos esta conotação em nenhum dos 38 casos em que acender surge como ação de personagens masculinos. Além disso, as velas acesas por elas não são tanto para iluminar, mas estão em um contexto de religiosidade, que não aparece no ambiente masculino.

Outro verbo interessante a analisar, porque surge como o de maior preferência para personagens femininas, é exercer. Vejamos o que eles e elas exercem:

Masculinos:

id="Contos_fora_da_moda Prosa:conto ArtA 1894 masc ": Maurício exercia na Alfândega um modesto emprego de escriturário, e, como residisse nas proximidades do Passeio Público, e era por natureza comodista e ordenado, tomava sistematicamente, às nove horas, 0 bondinho que contornava parte do morro do castelo, e ia despejar-lo no Carceler, perto da repartição .

id="A_falência Prosa:romance JLdA 1901 naturalismo_realismo fem ": No fundo, não era só a distração que ele buscava, nem a caridade que ele exercia; uma outra causa lhe filtrava nalma aquela vocação para o beneficio...

id="A_falência Prosa:romance JLdA 1901 naturalismo_realismo fem ": Era a filha mais velha e a mais instruída: pilhara os Tempos das vacas gordas, quando o pai exercia um cargo lucrativo . 
Femininos:

id="O_Cortiço Prosa:romance AA 1890 naturalismo masc ": Que estranho poder era esse, que a mulher exercia sobre eles, a tal ponto, que os infelizes, carregados de desonra e de ludibrio, ainda vinham covardes e suplicantes mendigar-lhe o perdão pelo mal que ela lhes fizera? ...

id="Água_de_Juventa Prosa:contos CN 1905 realismo masc ": Ela fez-me sinal para que me não movesse e eu sentia-me dominado -- era uma fascinação que aquela mulher exercia sobre mim ou era o assombro de tão insólita cena que me tolhia e avassalava .

id="Antes_que_cases Prosa:conto MdA 1875 masc ": A influência que a mulher exercia nele não podia ser mais decisiva .

id="A_pianista Prosa:conto MdA 1866 masc ": Ora, entre as famílias onde Malvina exercia as suas funções de pianista, contava-se, em 1850, a família de Tibério Gonçalves Valença .

id="Cartas_Fluminenses Prosa:crônica MdA 1867 masc ": O luxo firma o seu trono; essa peste, que veio da Ásia para acabar com os restos da severidade romana, é a condição essencial do pontificado que a senhora exerce na igreja do diabo, que Santo Agostinho diz imitar a igreja de Deus -- e eu peço licença para desmentir o padre ao menos neste assunto .

id="Comentários_da_semana Prosa:crônica MdA 1861 masc ": Na apoteose dos talentos, bem como no conforto dos que padecem, a mulher exerce sempre a sua alta missão; tanto galardoa como consola .

id="Helena Prosa:romance MdA 1876 romantismo masc ": Estácio conhecia já o domínio que a moça exercia sobre si mesma; a tranqüilidade não o convenceu .

id="Memorial_de_Aires Prosa:romance MdA 1908 realismo masc ": Desde namorada, ela exerceu sobre ele a influência de todas as namoradas deste mundo, e acaso do outro, se as há tão longe . 
id="Memórias_póstumas_de_Brás_Cubas Prosa:romance MdA 1881 realismo masc ": Virgília exercia sobre ela verdadeira fascinação .

id="O_capitão_Mendonça Prosa:conto MdA 1870 masc ": Aquela moça exercia sobre mim uma pressão a um tempo doce e dolorosa; sentia-me escravo dela, a minha vida como que se fundia na sua; era uma fascinação vertiginosa .

id="O_rei_dos_caiporas Prosa:conto MdA 1870 masc ": D. Angélica teve sempre o comando do exército doméstico, e devo acrescentar com a fidelidade de um romancista sincero que D. Angélica exercia esse comando com uma severidade digna de um general .

id="O_rei_dos_caiporas Prosa:conto MdA 1870 masc ": Então lembrou-se João das Mercês do domínio que a tia exercia no ânimo do marido, e calculou que a tristeza de Gaspar se prendesse ao generoso presente dos dez mil-réis .

id="Ressurreição Prosa:romance MdA 1872 romantismo masc ": De novo sentia o império que a viúva sempre exercera em seu espírito .

Aqui é um cenário inverso ao que vimos até então. Eles exercem cargos (profissionais) ou caridade. E elas, o que exercem é alguma forma de poder, domínio, influência, comando, pressão. Há apenas um caso em que exercer se refere a uma função - a de pianista. Foi uma surpresa identificar que o verbo de maior preferência para personagens femininas seja "exercer", pois não nos pareceia algo óbvio ou esperado.

E por fim, vemos os verbos que, curiosamente, têm exatamente o mesmo número de ocorrências tanto para personagens femininas, quanto masculinas: 


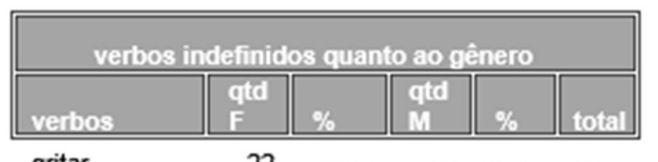

\begin{tabular}{llllll}
\hline gritar & 22 & $50 \%$ & 22 & $50 \%$ & 44 \\
aprender & 13 & $50 \%$ & 13 & $50 \%$ & 26
\end{tabular}

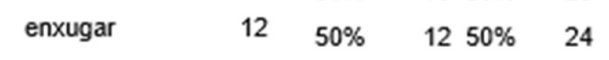

$\begin{array}{llllll}\text { estimar } & 9 & 50 \% & 9 & 50 \% & 18\end{array}$

$\begin{array}{llllll}\text { corresponder } & 9 & 50 \% & 9 & 50 \% & 18\end{array}$

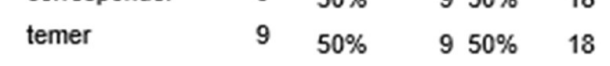

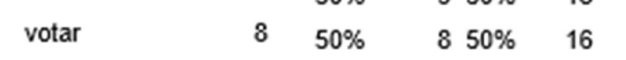

$\begin{array}{llllll}\text { negar } & 8 & 50 \% & 8 & 50 \% & 16\end{array}$

$\begin{array}{lllll}\text { escapar } & 6 & 50 \% & 650 \% & 12\end{array}$

$\begin{array}{lllll}\text { interrogar } & 6 & 50 \% & 650 \% & 12 \\ \text { acolher } & 5 & 50 \% & 550 \% & 10\end{array}$

$\begin{array}{lllll}\text { distribuir } & 5 & 50 \% & 550 \% & 10\end{array}$

$\begin{array}{lllll}\text { compor } & 5 & 50 \% & 550 \% & 10\end{array}$

$\begin{array}{lrrrr}\text { aludir } & 4 & 50 \% & 450 \% & 8\end{array}$

$\begin{array}{lllll} & & 50 \% & 450 \% & 8 \\ \text { valsar } & 4 & 50 \% & 450 \% & 8\end{array}$

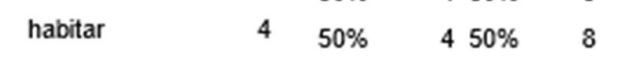

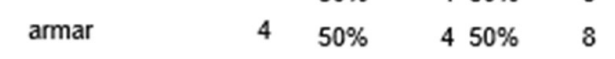

$\begin{array}{lllll}\text { alegar } & 3 & 50 \% & 350 \% & 6\end{array}$

$\begin{array}{lllll}\text { imitar } & 3 & 50 \% & 350 \% & 6\end{array}$

$\begin{array}{lllll}\text { riscar } & 3 & 50 \% & 350 \% & 6\end{array}$

$\begin{array}{lllll}\text { recomendar } & 3 & 50 \% & 350 \% & 6\end{array}$

$\begin{array}{lllll}\text { conquistar } & 3 & 50 \% & 350 \% & 6\end{array}$

$\begin{array}{lllll}\text { reproduzir } & 3 & 50 \% & 350 \% & 6\end{array}$

$\begin{array}{lllll}\text { pender } & 3 & 50 \% & 350 \% & 6\end{array}$

$\begin{array}{lllll} & 50 \% & 350 \% & 6 \\ \text { atacar } & 3 & 50 \% & 350 \% & 6\end{array}$

abocanhar $\quad 2 \quad 50 \%$

$\begin{array}{lll}\text { sarar } & 2 & 50 \% \\ \text { assegurar } & 2 & 50 \% \\ \text { gerar } & 2 & 50 \%\end{array}$

$\begin{array}{ll}350 \% & 6 \\ 250 \% & 4 \\ 250 \% & 4 \\ 250 \% & 4 \\ 250 \% & 4\end{array}$

\begin{tabular}{|c|c|c|c|c|c|}
\hline \multicolumn{6}{|c|}{ verbos indefinidos quanto ao gênero } \\
\hline verbos & $\begin{array}{l}\mathrm{qtd} \\
\mathrm{F} \\
\end{array}$ & $\%$ & $\begin{array}{l}\mathrm{qtd} \\
\mathrm{M} \\
\end{array}$ & $\%$ & total \\
\hline lidar & 2 & $50 \%$ & 2 & $50 \%$ & 4 \\
\hline rematar & 2 & $50 \%$ & 2 & $50 \%$ & 4 \\
\hline ensaiar & 2 & $50 \%$ & 2 & $50 \%$ & 4 \\
\hline avaliar & 2 & $50 \%$ & 2 & $50 \%$ & 4 \\
\hline elogiar & 2 & $50 \%$ & 2 & $50 \%$ & 4 \\
\hline assobiar & 2 & $50 \%$ & 2 & $50 \%$ & 4 \\
\hline desabafar & 2 & $50 \%$ & 2 & $50 \%$ & 4 \\
\hline rebentar & 2 & $50 \%$ & 2 & $50 \%$ & 4 \\
\hline sossegar & 2 & $50 \%$ & 2 & $50 \%$ & 4 \\
\hline insinuar & 2 & $50 \%$ & 2 & $50 \%$ & 4 \\
\hline esvaziar & 2 & $50 \%$ & 2 & $50 \%$ & 4 \\
\hline brilhar & 2 & $50 \%$ & 2 & $50 \%$ & 4 \\
\hline consolar & 2 & $50 \%$ & 2 & $50 \%$ & 4 \\
\hline recomeçar & 2 & $50 \%$ & 2 & $50 \%$ & 4 \\
\hline rondar & 2 & $50 \%$ & 2 & $50 \%$ & 4 \\
\hline pressentir & 2 & $50 \%$ & 2 & $50 \%$ & 4 \\
\hline varrer & 2 & $50 \%$ & 2 & $50 \%$ & 4 \\
\hline durar & 2 & $50 \%$ & 2 & $50 \%$ & 4 \\
\hline queimar & 2 & $50 \%$ & 2 & $50 \%$ & 4 \\
\hline concentrar & 2 & $50 \%$ & 2 & $50 \%$ & 4 \\
\hline envelhecer & 2 & $50 \%$ & 2 & $50 \%$ & 4 \\
\hline encerrar & 2 & $50 \%$ & 2 & $50 \%$ & 4 \\
\hline enganar & 2 & $50 \%$ & 2 & $50 \%$ & 4 \\
\hline denunciar & 2 & $50 \%$ & 2 & $50 \%$ & 4 \\
\hline juntar & 2 & $50 \%$ & 2 & $50 \%$ & 4 \\
\hline destinar & 2 & $50 \%$ & 2 & $50 \%$ & 4 \\
\hline namorar & 2 & $50 \%$ & 2 & $50 \%$ & 4 \\
\hline organizar & 2 & $50 \%$ & 2 & $50 \%$ & 4 \\
\hline pregar & 2 & $50 \%$ & 2 & $50 \%$ & 4 \\
\hline
\end{tabular}

Tabela 13 - Verbos que ocorrem o mesmo número de vezes para personagens femininas e masculinas (aqui aparecem apenas os que ocorrem mais de uma vez para cada gênero).

Ressaltamos aqui, findas as análises, que, como mencionado no capítulo 3, cada expressão de busca foi testada isoladamente, e avaliada com base nos resultados obtidos em linhas de concordância; e que para evitar que se obtivessem verbos que denotem ações negadas nas orações, todas as expressões de busca incluem a restrição que diz que pode haver ou não um advérbio modificando o verbo que se quer obter, exceto "não" e "nunca". 


\section{Considerações Finais}

Neste trabalho, apresentamos uma pesquisa de viés quantitativo e qualitativo, tomando por base um grande corpus composto por obras da literatura brasileira em domínio público, majoritariamente dos séculos XIX e XX, disponibilizado em formato eletrônico para consultas na ferramenta AC/DC. Nossa proposta foi desenvolver uma metodologia para identificação de caracterização das personagens do corpus, que se mostrou bem sucedida, para uma análise comparativa entre personagens femininas e masculinas. Além de contribuir como um recurso a mais para pesquisadores do discurso, pode ainda colaborar em diversas outras áreas de estudos sociais, e ainda ao evidenciar as diferenças de gênero presentes na carcaterizacao das personagens, ser um auxílio nos esforços para redução de viés de gênero na inteligência artificial, uma vez que pode ajudar equipes de programadores a tomarem ciência das (tendenciosas) diferenças de gênero presentes nos corpora textuais que utilizam para treinamento de sistemas de machine learning, podendo assim fazer uma escolha mais consciente do material ao ser utilizado. "As máquinas se tornam mais sexistas, racistas e classistas porque identificam a tendência subjacente e apostam nela para acertar", já que os dados de que dispõem contêm vieses implícitos. (Salas, 2017).

Obtivemos sucesso na criação das expressões de busca a partir de padrões do português que indicam predicações e ações. Vimos que elas foram capazes de extrair um número enorme de predicações e ações dos textos, e o índice de erros foi bem pequeno, mas sabemos que nem todas as caracterizações se esgotam nos padrões elencados. O corpus escolhido, por ser repleto de descrições de personagens, por ser anotado e acessível através da ferramenta AC/DC, foi essencial para a obtenção dos dados. A alternância entre leitura distante e aproximada mostrou que é possível alcançar a sinergia desejada entre os estudos do discurso e o trabalho com corpus. A análise foi feita através da distribuição em eixos semânticos e preferências. 
A distribuição nos eixos semânticos foi validada graças à utilização da ferramenta Rêve, e com isso traz confiança na análise inicial que fizemos, fundamental para as análises subsequentes, que por sua vez nos levaram a descobertas interessantes: sabíamos que a beleza era uma característica muito valorizada nas mulheres, mas não imaginávamos que o predicador "bonito" apareceria tantas vezes no corpus caracterizando personagens femininas, mais vezes até do que o predicador masculino mais frequente. $E$ também perceber que a aparência física realmente não aparece como relevante para personagens masculinos - nas obras de autoria feminina, "bonito" aparece na mesma proporção para mulheres e homens (preferência). As caracterizações que dizem respeito ao lugar social das personagens masculinas têm mais referências a ocupações, títulos e patentes militares, enquanto as femininas são mais ligadas a círculos familiares, apresentando-se como um espelho dos papéis sociais do século XIX.

Conseguimos identificar também preconceitos presentes nas preferências lexicais das ações que homens e mulheres exercem nos textos. Enquanto eles montam, elas cavalgam. Eles acendem cigarros e candelabros, elas acendem velas para santos. Foi bastante interessante refletir sobre esses dados, descobrir que eles, na verdade, estão bastante alinhados com nossa percepção da realidade, embora os exemplos extraídos nos tenham surpreendido. Também foi uma surpresa observar que exercer é o verbo com maior preferência feminina presente no corpus, e que ganhar é o de maior preferência masculina, foi muito interessante verificar os contextos em que aparecem.

Não realizamos o teste de Bechdel para este corpus, mas é uma ideia a ser trabalhada em futuramente. Também desejamos encontrar uma forma prática de categorizar as ações em eixos semânticos. Diante do crescimento do corpus, tão logo haja mais obras femininas presentes, poderemos fazer novas comparações para observarmos de forma mais significativa como as personagens se constroem no texto de autoria feminina. Também podemos desenvolver análises em outros corpora em 
língua portuguesa, comparar a construção das personagens na literatura portuguesa e na brasileira. As possibilidades de exploração são imensas.

Textos circulam na sociedade, carregados de ideologia, ajudam a criar hábitos e crenças, impondo uma determinada moral. Nossas análises evidenciam essas tendências muito claramente. Sabemos que esses discursos podem influenciar as pessoas que os leem, muitas vezes reduzindo a esperança e limitando oportunidades. Os dados quantitativos apresentados neste trabalho demonstram empiricamente a colocação de Butler quanto ao gênero ser construído por uma repetição performativa de atos desempenhados por mulheres e homens (Butler, 2019). A generalização em torno de estereótipos é uma prática já enraizada em todos nós, principalmente por conta da força performativa que tem a repetição. Tomar consciência dessas diferenças já naturalizadas, proporcionadas por privilégios, hábitos, preconceitos, imposições sócioculturais, poderia ser, talvez, um caminho para a construção de um mundo menos desigual e injusto. Se a linguagem constitui realidades e identidades, tanto nos textos escritos, como em cada ato de fala, precisamos perceber o que poderia ser diferente e começar a construir novas possibilidades em nossos discursos. Este estudo, como tantos outros que já vieram antes e ainda virão, pode servir como ferramenta para a evidenciação das injustiças e desigualdades a serem superadas também através do discurso e de outras ações políticas.

Enquanto desenvolvi esta pesquisa, questionei muito o meu lugar enquanto mulher, dona de casa, trabalhadora, filha, companheira. Observei a minha realidade e as "escolhas" que fiz até aqui. Percebi que nem todas foram voluntárias, como um dia acreditei, mas influenciadas pelos discursos que me cercaram ao longo da vida. Quando muito jovem ainda, acreditei que só poderia sair da casa dos meus pais se fosse casada. Por muito tempo acreditei que a felicidade estava em satisfazer meu companheiro, manter uma casa linda e arrumada para ser nosso lar. Mas, tendo feito dessas histórias que me cercavam também a minha história, logo percebi que a felicidade esperada não duraria muito tempo. A tomada 
de consciência pode ser muito dolorida e causar muita confusão, porque em seguida se faz necessário decidir se se permanece naquele lugar já conhecido e que não satisfaz ou se se arrisca tudo para se jogar no abismo da realidade desconhecida dos desejos próprios. Mas é importante que ela aconteça em algum momento, ainda que tardiamente. Quando conseguimos treinar nossos olhos para perceberem os valores implícitos que circulam nos discursos que produzimos e naqueles que nos atingem, jamais será possível não atentar para eles. Arrisco-me a dizer que esta dissertação só conseguiu ser concluída porque em determinado momento decidi seguir pelo caminho do abismo. 


\section{Referências Bibliográficas}

ARSTEIN, R. Inter-Annotator Agreement. In: IDE, N. e PUSTEJOVSKY, J. (Eds.) Handbook of Linguistic Annotation. 297-313. Dordrecht: Springer, 2017.

AZEREDO, J. C. Gramática Houaiss da língua portuguesa. 2 ed. São Paulo: Publifolha, 2008.

BAGNO, Marcos. Gramática Pedagógica do Português Brasileiro. São Paulo, Parábola, 1056p. 2011

BAKER, P. Sociolinguistics and Corpus Linguistics. Edinburgh: Edinburgh University Press, 2010.

BAKER, P. et al. A Useful Methodological Synergy? Combining Critical Discourse Analysis and Corpus Linguistics to Examine Discourses of Refugees and Asylum Seekers in the UK Press. Discourse \& Society, 19(3), 273-306, 2008.

BEAUVOIR, S. O Segundo sexo: Vol. 1: Fatos e Mitos. $3^{\text {a }}$. Ed. Rio de Janeiro, Nova Fronteira, 2016 [1949].

BICK, Eckhard. The Parsing System "Palavras": Automatic Gramatical Analysis. Aarhus: Aarhus University Press, 2000.

BUTLER, J. Problemas de gênero: feminismo e subversão de identidade. Rio de Janeiro, Civilização Brasileira, 2019. 17ª . Edição.

CÂMARA JR, J. M. Estrutura da língua portuguesa. Petrópolis: Vozes, 1970.

CAMERON, D. More Heat Than Light? Sex-difference Science \& the Study of Language (Garnett Sedgewick Memorial Lecture) Vancouver: Ronsdale Press, 2012. CANDIDO, Antônio. Literatura e personagem. In: 
CAMERON, D. \& PANOVIĆ, I. Working with Written Discourse. London: Sage, 2014.

CANDIDO, A. Literatura e Personagem. In: CANDIDO, A. et al. A Personagem de Ficção. São Paulo: Editora Perspectiva, 2014, 13a edição.

COSTA, B.; FREITAS, C. Um léxico de verbos do dizer para tradutores - e considerações sobre a classificação dos verbos de elocução. In: Calidoscópio, n. 17. São Leopoldo: Unisinos, 2019.

DEUTSCHER, Guy. Through the language glass: why the world looks different in other languages. 1' ${ }^{\text {st }}$. Ed. New York: Metropolitan Books, 2010.

DUARTE, C. L. Feminismo: uma história a ser contada. In Pensamento Feminista Brasileiro: Formação e Contexto. Rio de Janeiro: Bazar do Tempo, 2019.

ELLIS, J. M. Language, Thought and Logic. Evanston, IL: Northwestern University Press, 1993.

FABRÍCIO, B. F. Linguística Aplicada como espaço de "desaprendizagem": redescrições em curso. In: Por uma Linguística Aplicada Indisciplinar. São Paulo: Parábola Editorial, 2006.

FREITAS, C. Estudos linguísticos e Humanidades Digitais: corpus e descorporificação. Gragoatá, vol. 22, n. 44, p.1207-1227. 2017. Disponível em: http://www.gragoata.uff.br/index.php/gragoata/article/view/1015

FREITAS, C., de SOUZA, E. (2021) Sujeito Oculto às claras. Revista de Estudos da Linguagem v.29, n.2. (no prelo)

FREITAS, C., BIAR, L. \& MARTINS, F. Construções do feminino na literatura brasileira: discurso, grandes corpora e leitura não-linear. (no prelo)

HEARST, M. A. Automatic acquisition of hyponyms from large text corpora. Proceedings of the 14th International Conference on Computational 
Linguistics, $\quad 1992 . \quad$ Dantes, Disponível em: http://www.aclweb.org/anthology/C92-2082

HEARST, M. A. Untangling Text Data Mining. In: Proceedings of the 37th Annual Meeting of the Association for Computational Linguistics. Maryland, Association for Computational Linguistics, 1999.

HEARST, M. A. What is Text Mining? Berkeley, 2003. Disponível em: http://people.ischool.berkeley.edu/ hearst/text-mining.html

HOOKS, B. (2019) O feminismo é para todo mundo: políticas arrebatadoras. 5a . Ed. Rio de Janeiro: Rosa dos Tempos, 2019

LAKOFF, G. Women, Fire and Dangerous Things: What Categories Reveal about the Mind. Chicago: University of Chicago Press. 1987.

McENERY, T. \& HARDIE, A. Corpus Linguistics: Method, theory and practice. Cambridge: Cambridge University Press. (2012)

McENERY, T. \& WILSON, A. Corpus Linguistics: An Introduction. Edinburgh University Press, 2001.

MAUTNER, G. Corpora and critical discourse analysis. In: P. Baker (ed.), Contemporary Corpus Linguistics. London: Continuum, 2009

MOITA LOPES. L. P. Gênero, sexualidade, raça em contextos de letramentos escolares. In: MOITA LOPES, L. P. (org.). Linguística Aplicada na modernidade recente: Festschrift para Antonieta Celani. São Paulo: Parábola Editorial, 2013.

MORETTI, F. A Literatura vista de longe. Trad: Anselmo Pessoa Neto. Porto Alegre: Arquipélago, 2008 [2005].

MULVEY, L. Prazer Visual e Cinema Narrativo. In: Xavier, I. A experiência do cinema. Rio de Janeiro: Edições Graal, 437-454. (1973)

NIETZSCHE, F. W. Sobre verdade e mentira no sentido extra-moral. In: Obras incompletas/Friedrich Nietzsche. Série: Os Pensadores. Seleção de 
textos de Gérard Lebrun; Trad. e notas: Rubens Rodrigues Torres Filho. 4. ed. São Paulo: Nova Cultura, 1911 [1987].

PAIXÃO de SOUZA, M. C. P. A Filologia Digital em Língua Portuguesa: alguns caminhos. In: GONÇALVES; BANZA, A. P. (eds.). Património Textual e Humanidades Digitais: da antiga à nova Filologia. Évora: CIDEHUS, $2013 . \quad$ Disponível em: http://dspace.uevora.pt/rdpc/bitstream/10174/10468/1/e-book.pdf. Acesso em: 16/09/2019.

SALAS, J. Se está na cozinha, é uma mulher: como os algoritmos reforçam preconceitos. Els País, 2017. Disponível em: https://brasil.elpais.com/brasil/2017/09/19/ciencia/1505818015_847097.ht $\mathrm{ml}$

SANTOS, D. Corporizando algumas questões. In: TAGNIN, S. E. O. e VALE, O. A. (eds.). Avanços da Lingüística de Corpus no Brasil. USP, São Paulo; São Paulo, Brasil: Editora Humanitas; Editora Humanitas/FFLCH/USP, 2008.

SANTOS, D. Podemos contar com as contas? In: ALUÍSIO, S. e TAGNIN, S. (eds.), New Language Technologies and Linguistic Research: A Twoway Road, Cambridge Scholars Publishing, 2014.

SANTOS, D. et al. Comparando anotações linguísticas na Gramateca: filosofia, ferramentas e exemplos. In: Domínios de Linguagem. 9, n. 2 (abr./jun. 2015) Disponível em:

http://www.seer.ufu.br/index.php/dominiosdelinguagem/article/view/30798/ 17555

SANTOS, D.; FREITAS, C.; BICK, E. OBras: a fully annotated and partially human-revised corpus of Brazilian literary works in the public domain. OpenCor, Canela, RGS, Brasil, 24 de setembro de 2018.

SANTOS, D.; BICK, E. Providing Internet access to Portuguese corpora: the AC/DC project. In Maria Gavrilidou, George Carayannis, Stella Markantonatou, Stelios Piperidis \& Gregory Stainhauer (eds.), Proceedings 
of the Second International Conference on Language Resources and Evaluation (LREC 2000) (Atenas, Grécia, 31 de Maio a 2 de Junho de 2000), pp. 205-210.

SMITH, S. CHOUEITI, M.; PIEPER, K. Gender Bias Without Borders: An Investigation of Female Characters in Popular Films Across 11 Countries. The Geena Davis Institute on Gender and Media and the Social Change Initiative at USC Annenberg, 2014. Disponível em: <https://seejane.org/wpcontent/uploads/genderbias-without-borders-executive-summary.pdf $>$.

Acesso em: 16/09/2019.

WOOLF, Virginia. Um teto todo seu. Rio de Janeiro, Nova Fronteira, 2019 [1929]. $2^{\mathrm{a}}$. Ed. 
Eixos semânticos dos predicadores

Em que categoria(s) semântica(s) cada um dos predicadores em negrito se encaixa melhor, levando em conta o contexto da frase em que está inserido? É possível selecionar mais de um para cada resposta. Corpo/físico - aspectos físicos, do corpo (exemplos: bonita, alto, magro, nu) Emoção/afeto - emoções e sentimentos (exemplos: triste, feliz) Lugar social - caracterizações sociais, profissionais, familiares (exemplos: pobre, solteira, professor, empregado, irmã Caráter/personalidade (exemplos: digno, sério, gentil, romântico, mau, tímido)

28429: A velha Salomé , aflita, ia de vez em quando à janela e voltava desapontada, agitando os ombros e sacudindo a cabeça .

74900: A Machona altercava com uma preta que fora reclamar um par de meias e destrocar uma camisa ; a Augusta , muito mole sobre a sua tábua de lavar , parecia derreter-se como sebo ; a Leocádia largava de vez em quando a roupa e o sabão para coçar as comichões do quadril e das virilhas , assanhadas pelo mormaço ; a Bruxa monologava , resmungando numa insistência de idiota, ao lado da Marciana que, com o seu tipo de mulata velha, um cachimbo ao canto da boca , cantava toadas monótonas do sertão : « Maricas tá marimbando ,

80493: João Romão, de roupa mudada como os outros , mas sempre em mangas de camisa, aparecia de espaço em espaço, servindo os comensais ; e a Bertoleza , sempre suja e tisnada , sempre sem domingo nem dia santo, lá estava ao fogão, mexendo as panelas e enchendo os pratos .

84226: À sobremesa o esfogueado amigo da dona da casa exigiu que a amante se lhe assentasse nas coxas e dava-lhe beijos em presença de toda a companhia , o que fez com que Dona Isabel , impaciente por afastar a filha daquele inferno, declarasse que sentia muito calor e que ia lá para a porta esperar mais à fresca o café .

85076: E via-se de relance Dona Estela, com a sua palidez de flor meia fanada , e Zulmira , lívida , um ar de fastio a fazê-la feia , e o Henriquinho , cada vez mais bonito, e o velho Botelho, indiferente, a olhar para toda esta porcaria do mundo com o profundo desprezo dos que já não esperam nada dos outros, nem de si próprios .

87179: Meu marido é pobre e é de cor , mas eu sou feliz, porque casei por meu gosto! 
88149: E , arrastado por ela , pulou à arena o Firmo , ágil , de borracha , a fazer coisas fantásticas com as pernas, a derreter-se todo, a sumir-se no chão , a ressurgir inteiro com um pulo, os pés no espaço, batendo os calcanhares, os braços a querer fugirem-lhe dos ombros, a cabeça a querer saltar-lhe .

95948: Em uma das vezes em que o cavouqueiro perguntou-lhe, como de costume, pela pobrezinha de Cristo , a mulata disse que Leocádia estava grávida .

239513: Quando Branca estava aborrecida , durante pequenas viagens comerciais do marido, André , em lugar da enfadonha história , lia-lhe alguns dos seus poetas mais prezados, clássicos na maior parte, entre os quais se destacavam Camões e Garrett, por quem ele sentia verdadeiro fanatismo .

257530: é impossível que Branca, tão inteligente e tão lúcida , não me compreenda e não perceba as minhas intenções!

286229: Ele estava bem encaminhado e pouco Ihe faltava para terminar a carreira ...

304666: Em breve , a Justina era tão indispensável para Magdá , quanto uma ama a um orfãozinho recém-nascido .

408711: Ela está aí fina e lampeira, que faz gosto, ao passo que a pobre da senhora D. Maria do Carmo ...

465185: O Freitas notou que ele estava rapagão ; estava muito melhor ; mais desenvolvido!

699253: Gonçalo , supersticioso como todo o homem ignorante , acreditava piamente em todas essas virtudes da mandinga, e a trazia cuidadosamente cosida em seu cinturão de couro de lontra .

700820: Maroca , naturalmente travessa e desenvolta , como um diabrete , não gostava nada dessa reserva, que não lhe permitia sair sempre ao meio da sala sapateando doidamente como as outras .

1268276: Maria Augusta , sucumbida , tinha a cabeça baixa , as lágrimas rolavam-Ihe dos olhos e, de vez em quando, em acessos, sobrevinham soluços que a agitavam nervosamente .

1405159: Ritinha , sempre lânguida , encostada à cômoda , olhava-o com os seus grandes olhos negros, aveludados que, por vezes, pareciam adormecer à sombra dos longos cílios .

2155522: Padre Marcelino era cabeçudo, sem entranhas, de poucas brincadeiras, e tinha ódio mortal a tudo que era ou lhe parecia maçom .

2164104: O Chico Fidêncio era maçom, inimigo dos jesuítas, mas não era contrário à verdadeira religião ! 
2788716: Enquanto Luciano Ihe dizia quanto tinha sofrido com esse casamento e a espécie de alívio que sentira ao sabê-la viúva , enquanto ele , cheio de sedução, se apoderava da sua mão esguia e branca e the dizia que viera da Europa por ela , só por ela ; Ernestina , trêmula , envergonhava-se da sua mentira, parecendo-lhe sentir os olhos do esposo fixos nela .

970: Frei Ozéas era um homem singularíssimo , como mais adiante apreciará o leitor. .

96201: -- Ele tem a cabeça virada por uma mulher trigueira .

113155: Pungia-lhe na brancura da alma virgem um arrependimento incisivo e negro das torpezas da antevéspera ; mas, lubrificada por essa recordação, toda a sua carne ria e rejubilava-se, pressentindo delicias que Ihe pareciam reservadas para mais tarde, junto de um homem amado , dentro dela balbuciavam desejos, até ai mudos e adormecidos ; e mistérios desvendavam-se no segredo do seu corpo, enchendo-a de surpresa e mergulhando-a em fundas concentrações de êxtase .

151092: no fim dos seus primeiros dois anos de casada já não podia suportar o marido ; todavia , a principio , para conservar-se mulher honesta , tentou perdoar-lhe a falta de espírito, os gostos rasos e a sua risonha e fatigante palermice de homem sem ideal ; ouviu-lhe, resignada, as confidências banais nas horas intimas do matrimônio ; atendeu-o nas suas exigências mesquinhas de ciumento que chora ; tratou-o com toda a solicitude, quando ele esteve a decidir com uma pneumonia aguda ; procurou afinar em tudo com o pobre rapaz; não Ihe falou nunca em coisas que cheirassem a luxo , a arte , a estética , a originalidade ; escondeu a sua mal-educada e natural intuição pelo que é grande , ou belo , ou arrojado , e fingiu ligar interesse ao que ele fazia, ao que ele dizia, ao que ele ganhava, ao que ele pensava e ao que ele conseguia com paciência na sua vida estreita de negociante rotineiro ; mas, de repente, zás!

523480: Eu só amara mulheres perdidas .

699592: Era uma malta de rapazes ociosos e devassos, da qual ele por sua superioridade em forças e destreza e por sua riqueza e generosidade era o chefe natural.

1183433: Um homem esfarrapado , descalço , barba farta e inculta , um velho chapéu de palha enterrado na cabeça, com um cão no rastro, vinha vindo lentamente, vergado como a um grande peso .

1495495: O próprio niilismo, com as suas mulheres varonis , os seus pensadores severos, os seus poetas sentimentais e ferozes, e os seus facínoras românticos -- um desvario dentro de um generoso ideal -- reponta às vezes, nesta crise, como a forma tormentosa e assombradora da justiça 
1607141: Algum tempo depois de travado o conflito em Tabuleirinhos, os habitantes de Canudos, impressionados com a intensidade dos tiroteios , alarmaram-se ; e prevendo as conseqüências que adviriam se os soldados ali chegassem, de chofre , caindo sobre a beataria medrosa , João Abade reuniu o resto dos homens válidos, cerca de seiscentos, seguindo em reforço aos companheiros .

1853103: Batei nas faces, mulheres ímpias .

1904518: Aos seus olhos, eu devo ser hoje uma mulher vulgar , senão desprezível .

1930948: Criemos as meninas com decoro, vestindo-as com discrição, e teremos moças discretas, pudicas, decorosas, ciosas do seu corpo e dos seus encantos.

9829: -- Um homem virgem em pleno século dezoito ! ...

221042: Se ela fosse jeitosa ao menos ; mas não tem gosto para nada , não sabe pôr um vestido, não sabe por um chapéu ; e , em vez de endireitar com o tempo, parece que vai ficando cada vez mais estúpida!

149563: No fim de uma boa pausa, Botelho perguntou se Bertoleza era escrava quando João Romão tomou conta dela .

8386: Começando pelo rei , que fora o seu primeiro amante, pertencera ela depois simultaneamente, ora mais, ora menos tempo, a toda a gente da corte capaz de manter mulheres caras .

689741: -- Muito bem, Isaura ; mostras que és uma rapariga dócil e de juízo .

1016316: E a coitada da mulher sozinha , com o peso todo da vida , três bocas para sustentar .

1420152: E ele, vencido, dominado por aquela viçosa criatura de amor que , quando andava, bambaleando os quadris e balançando molemente os braços roliços, deixava no ar um cheiro acre de carne, um almíscar estonteante de mulher ardente , não teve ânimo de sair e ficou sentado até que ela, ouvindo as horas no lento relógio, veio do fundo da casa , penteando os cabelos lisos, dizer, com espanto: 


\section{Apêndice 2 - Expressão de busca para o predicador "belo".}

\section{Feminino:}

([sema="."Pessoa. *" \& gen="F" \& func="SUBJ>"] [lema="ser|estar"] [pos="ADV. *"] @[lema="belo" \& temcagr!=".*PASS. *" \& pos="ADJ|N|V" \& func="<SC"])|([sema=".*Pessoa. *" \& gen="F" \& func="SUBJ>"] [lema="ser|estar"] [pos="ADV."]" [pos="ADJ. *" \& gen="F" \& func!=">N"] "e" @[lema="belo" \& pos="ADJ.*" \& func!=">N"])|([sema=".*Pessoa. *" \& gen="F" \& func="SUBJ>"] [lema="ser|estar"] [pos="ADV.*"]* [pos="ADJ.*" \& gen="F" \& func!=">N"] "," @[lema="belo" \& pos="ADJ.*" \& func!=">N"])|([sema="parentesco" \& gen="F" \& func="SUBJ>"] [word="de|do|da"] [sema="Pessoa"]* [lema="ser|estar"] [pos="ADV.*"]* @[lema="belo" \& temcagr!=". *PASS. *" \& pos="ADJ|N|V" \& func="<SC"])|([sema="parentesco" \& gen="F" \& func="SUBJ>"] [word="de|do|da"] [sema="Pessoa"] [lema="ser|estar"] [pos="ADV. *"]* [pos="ADJ.*" \& gen="F" \& func!=">N"] "e" @[lema="belo" \& pos="ADJ." \& func!=">N"])|([sema="parentesco" \& gen="F" \& func="SUBJ>"] [word="de|do|da"] [sema="Pessoa"]* [lema="ser|estar"] [pos="ADV. *"] [pos="ADJ." \& gen="F" \& func!=">N"] "," @[lema="belo" \& pos="ADJ.*" \& func!=">N"])|([lema="mulher|moça|rapariga|menina|senhora" \& func="SUBJ>"] [lema="ser|estar"] [pos="ADV.*"]* @[lema="belo" \& temcagr!="."PASS. *" \& pos="ADJ|N|V" \& func="<SC"])|([lema="mulher|moça|rapariga|menina|senhora" \& func="SUBJ>"] [lema="ser|estar"] [pos="ADV.*"]* [pos="ADJ.*" \& gen="F" \& func!=">N"] "e" @[lema="belo" \& pos="ADJ." \& func!=">N"])|([lema="mulher|moça|rapariga|menina|senhora" \& func="SUBJ>"] [lema="ser|estar"] [pos="ADV.*"]* [pos="ADJ." \& gen="F" \& func!=">N"] "," @[lema="belo" \& pos="ADJ.*" \& func!=">N"])|([lema="ela" \& func="SUBJ>"] [lema="ser|estar"] [pos="ADV.*"]* @[lema="belo" \& temcagr!="..PASS. *" \& pos="ADJ|N|V" \& func="<SC"])|([lema="ela" \& func="SUBJ>"] [lema="ser|estar"] [pos="ADV.."]* [temcagr!=". *PASS.*" \& pos="ADJ|N|V" \& gen="F" \& func="<SC"] "e" @[lema="belo" \& pos="ADJ.*" \& func!=">N"])|([lema="ela" \& func="SUBJ>"] [lema="ser|estar"] [pos="ADV.*"]* [temcagr!=".*PASS.*" \& pos="ADJ|N|V" \& gen="F" \& func="<SC"] "," @[lema="belo" \& pos="ADJ.*" \& func!=">N"])|([sema=".*Pessoa.*" \& func!="P<"] "," [pos="ADV.*"]* @[lema="belo" \& func="N<PRED|. *APP.." \& gen="F" \& pos="ADJ"])|([sema=".*Pessoa. *" \& func!="P<"] "," [pos="ADV. *"]* [func="N<PRED|. *APP. *" \& gen="F" \& pos="ADJ"] "e" @[lema="belo" \& gen="F" \& pos="ADJ"])|([sema=". ${ }^{*}$ Pessoa. *" \& func!="P<"] "," [pos="ADV. *"] [func="N<PRED|. APP. *" \& gen="F" \& pos="ADJ"] "," @[lema="belo" \& gen="F" \& pos="ADJ"])|([lema="mulher|moça|rapariga|menina|senhora"] "," [pos="ADV.*"]* @[lema="belo" \& func="N<PRED|. *APP. *" \& gen="F" \& pos="ADJ"])| ([lema="mulher|moça|rapariga|menina|senhora"] "," [pos="ADV. *"] [func="N<PRED|. *APP.*" \& gen="F" \& pos="ADJ"] "e" @[lema="belo" \& gen="F" \& pos="ADJ"])|([lema="mulher|moça|rapariga|menina|senhora"] "," [pos="ADV.""]* [func="N<PRED|.*APP.*" \& gen="F" \& pos="ADJ"] "," @[lema="belo" \& gen="F" \& pos="ADJ"])|([lema="ela" \& func="SUBJ>"] "," [pos="ADV.*"]* [func="N<PRED|.*APP.*" \& gen="F" \& pos="ADJ"] "e" @[lema="belo" \& gen="F" \& pos="ADJ"])|([lema="ela" \& func="SUBJ>"] "," [pos="ADV.*"]* [func="N<PRED|. *APP.*" \& gen="F" \& pos="ADJ"] "," @[lema="belo" \& gen="F" \& pos="ADJ"])|([lema="ela" \& func="SUBJ>"] "," [pos="ADV.*"]* @[lema="belo" \& func="N<PRED|. *APP. *" \& gen="F" \& pos="ADJ"])|([lema="mulher|moça|rapariga|menina|senhora"] @[lema="belo" \& pos="N|ADJ|V" \&

func="<PRED $|<O C| N<"]) \mid([$ lema="mulher|moça|rapariga|menina|senhora"] [pos="N|ADJ|V" \& func="<PRED $|<O C| N<"]$ "e" @[lema="belo" \& pos="ADJ" \& gen="F"])|([lema="mulher|moça|rapariga|menina|senhora"] [pos="N|ADJ|V" \& func="<PRED $|<O C| N<"]$ "," @[lema="belo" \& pos="ADJ" \& gen="F"])|([lema="mulher|moça|rapariga|menina|senhora"] [pos="N|ADJ|V" \& func="<PRED $|<O C| N<$ "] "," [pos="ADJ"] "," @[lema="belo" \& pos="ADJ" \& gen="F"])|([lema="mulher|moça|rapariga|menina|senhora"] [pos="N|ADJ|V" \& func="<PRED $|<O C| N<"]$ "," [pos="ADJ"] "e" @[lema="belo" \& pos="ADJ" \& gen="F"])|([sema="parentesco" \& gen="F"] @[lema="belo" \& pos="N|ADJ|V" \& func $="<P R E D|<O C| N<"])$ 


\section{Masculino:}

([sema=".*Pessoa.*" \& gen="M" \& func="SUBJ>"] [lema="ser|estar"] [pos="ADV. *"]* @[lema="belo" \& temcagr!=".*PASS. *" \& pos="ADJ|N|V" \& func="<SC"])|([sema=".*Pessoa. *" \& gen="M" \& func="SUBJ>"] [lema="ser|estar"] [pos="ADV. *"] [pos="ADJ."" \& gen="M" \& func!=">N"]* "e" @[lema="belo" \& pos="ADJ." \& func!=">N"])|([sema=".*Pessoa.*" \& gen="M" \& func="SUBJ>"] [lema="ser|estar"] [pos="ADV.*"]* [pos="ADJ.*" \& gen="M" \& func!=">N"]* "," @[lema="belo" \& pos="ADJ.*" \& func!=">N"])|([sema="parentesco" \& gen="M" \& func="SUBJ>"] [word="de|do|da"] [sema="Pessoa"]* [lema="ser|estar"] [pos="ADV."]* @[lema="belo" \& temcagr!="."PASS.." \& pos="ADJ|N|V" \& func="<SC"])|([sema="parentesco" \& gen="M" \& func="SUBJ>"] [word="de|do|da"]* [sema="Pessoa"] [lema="ser|estar"] [pos="ADV." "] [pos="ADJ. *" \& gen="M" \& func!=">N"] "e" @[lema="belo" \& pos="ADJ.*" \& func!=">N"])|([sema="parentesco" \& gen="M" \& func="SUBJ>"] [word="de|do|da"] [sema="Pessoa"]* [lema="ser|estar"] [pos="ADV.*"]* [pos="ADJ." \& gen="M" \& func!=">N"] "," @[lema="belo" \& pos="ADJ.*" \& func!=">N"])|([lema="homem|moço|rapaz|menino|senhor" \& func="SUBJ>"] [lema="ser|estar"] [pos="ADV.*"]* @[lema="belo" \& temcagr!="."PASS.*" \& pos="ADJ|N|V" \& func="<SC"])|([lema="homem|moço|rapaz|menino|senhor" \& func="SUBJ>"] [lema="ser|estar"] [pos="ADV.*"]* [pos="ADJ." \& gen="M" \& func!=">N"] "e" @[lema="belo" \& pos="ADJ." \& func!=">N"])|([lema="homem|moço|rapaz|menino|senhor" \& func="SUBJ>"] [lema="ser|estar"] [pos="ADV.*"]* [pos="ADJ.*" \& gen="M" \& func!=">N"] "," @[lema="belo" \& pos="ADJ." \& func!=">N"])|([lema="ele" \& func="SUBJ>"] [lema="ser|estar"] [pos="ADV."]* @[lema="belo" \& temcagr!="."PASS. *" \& pos="ADJ|N|V" \& func="<SC"])|([lema="ele" \& func="SUBJ>"] [lema="ser|estar"] [pos="ADV.*"] [temcagr!=".*PASS.*" \& pos="ADJ|N|V" \& gen="M" \& func="<SC"] "e" @[lema="belo" \& pos="ADJ.*" \& func!=">N"])|([lema="ele" \& func="SUBJ>"] [lema="ser|estar"] [pos="ADV.*"]* [temcagr!=".*PASS.*" \& pos="ADJ|N|V" \& gen="M" \& func="<SC"] "," @[lema="belo" \& pos="ADJ.*" \& func!=">N"])|([sema=".*Pessoa. *" \& func!="P<"] "," [pos="ADV.*"]* @[lema="belo" \& func="N<PRED|. *APP. *" \& gen="M" \& pos="ADJ"])|([sema=".*Pessoa. *" \& func!="P<"] "," [pos="ADV. *"] [func="N<PRED|.*APP.*" \& gen="M" \& pos="ADJ"] "e" @[lema="belo" \& gen="M" \& pos="ADJ"])|([sema=".*Pessoa.*" \& func!="P<"] "," [pos="ADV. *"]* [func="N<PRED|. APP. *" \& gen="M" \& pos="ADJ"] "," @[lema="belo" \& gen="M" \&

pos="ADJ"])|([lema="homem|moço|rapaz|menino|senhor"] "," [pos="ADV. *"]* @[lema="belo" \& func="N<PRED|. *APP.*" \& gen="M" \& pos="ADJ"])|([lema="homem|moço|rapaz|menino|senhor"] "," [pos="ADV." "]* [func="N<PRED|. *APP.*" \& gen="M" \& pos="ADJ"] "e" @[lema="belo" \& gen="M" \& pos="ADJ"])|

([lema="homem|moço|rapaz|menino|senhor"] "," [pos="ADV.*"]* [func="N<PRED|. *APP. *" \& gen="M" \& pos="ADJ"] "," @[lema="belo" \& gen="M" \& pos="ADJ"])|([lema="ele" \& func="SUBJ>"] "," [pos="ADV.*"]* @[lema="belo" \& func="N<PRED|.*APP.*" \& gen="M" \& pos="ADJ"])|([lema="ele" \& func="SUBJ>"] "," [pos="ADV. *"]* [func="N<PRED|. APP. *" \& gen="M" \& pos="ADJ"] "e" @[lema="belo" \& gen="M" \& pos="ADJ"])|([lema="ele" \& func="SUBJ>"] ","

[pos="ADV.*"]* [func="N<PRED|. *APP.*" \& gen="M" \& pos="ADJ"] "," @[lema="belo" \& gen="M" \& pos="ADJ"])([lema="homem|moço|rapaz|menino|senhor"] @[lema="belo" \& pos="N|ADJ|V" \& func="<PRED $|<O C| N<"]) \mid([$ lema="homem|moço|rapaz|menino|senhor"] [pos="N|ADJ|V" \& func="<PRED $|<O C| N<"]$ "," @[lema="belo" \& pos="ADJ"])|([lema="homem|moço|rapaz|menino|senhor"] [pos="N|ADJ|V" \& func="<PRED $|<O C| N<"]$ "," [pos="ADJ"] "," @[lema="belo" \& pos="ADJ"])| ([lema="homem|moço|rapaz|menino|senhor"] [pos="N|ADJ|V" \& func="<PRED|<OC|N<"] "," [pos="ADJ"] "e" @[lema="belo" \& pos="ADJ"])|([lema="homem|moço|rapaz|menino|senhor"] [pos="N|ADJ|V" \& func="<PRED|<OC|N<"] "e" @[lema="belo" \& pos="ADJ" \& gen="M"])|([sema="parentesco" \& gen="M"] @[lema="belo" \& pos="N|ADJ|V" \& func $="<P R E D|<O C| N<"])$ 


\section{Apêndice 3 - Expressão de busca por predicadores}

\section{Feminino:}

([sema=".*Pessoa." \& gen="F" \& func="SUBJ>"] [lema="ser|estar"] [pos="ADV.*"]* @[temcagr!=".*PASS. *" \& pos="ADJ|N|V" \& func="<SC"])|

([sema="."Pessoa. *" \& gen="F" \& func="SUBJ>"] [lema="ser|estar"] [pos="ADV."]" [pos="ADJ." \& gen="F" \& func!=">N"] "e" @[pos="ADJ.*" \& func!=">N"])|

([sema=". *Pessoa.*" \& gen="F" \& func="SUBJ>"] [lema="ser|estar"] [pos="ADV.*"] [pos="ADJ." \& gen="F" \& func!=">N"] "," @[pos="ADJ." \& func!=">N"])

([sema="parentesco" \& gen="F" \& func="SUBJ>"] [word="de|do|da"] [sema="Pessoa"] [lema="ser|estar"] [pos="ADV. *"]* @[temcagr!=".*PASS.*" \& pos="ADJ|N|V" \& func="<SC"])|

([sema="parentesco" \& gen="F" \& func="SUBJ>"] [word="de|do|da"] [sema="Pessoa"]* [lema="ser|estar"] [pos="ADV."]" [pos="ADJ." \& gen="F" \& func!=">N"] "e" @[pos="ADJ.*" \& func!=">N"])|

([sema="parentesco" \& gen="F" \& func="SUBJ>"] [word="de|do|da"] [sema="Pessoa"]* [lema="ser|estar"] [pos="ADV.*"]* [pos="ADJ.*" \& gen="F" \& func!=">N"] "," @[pos="ADJ.*" \& func!=">N"])|

([lema="mulher|moça|rapariga|menina|senhora" \& func="SUBJ>"] [lema="ser|estar"] [pos="ADV.*"]* @[temcagr!=".*PASS. *" \& pos="ADJ|N|V" \& func="<SC"])|

([lema="mulher|moça|rapariga|menina|senhora" \& func="SUBJ>"] [lema="ser|estar"] [pos="ADV.*"]* [pos="ADJ." \& gen="F" \& func!=">N"] "e" @[pos="ADJ.*" \& func!=">N"])|

([lema="mulher|moça|rapariga|menina|senhora" \& func="SUBJ>"] [lema="ser|estar"] [pos="ADV. *"]* [pos="ADJ. *" \& gen="F" \& func!=">N"] "," @[pos="ADJ.*" \& func!=">N"])|

([lema="ela" \& func="SUBJ>"] [lema="ser|estar"] [pos="ADV.*"]* @[temcagr!=". *PASS. *" \& pos="ADJ|N|V" \& func="<SC"])|

([lema="ela" \& func="SUBJ>"] [lema="ser|estar"] [pos="ADV.*"]* [temcagr!="."PASS.*" \& pos="ADJ|N|V" \& gen="F" \& func="<SC"] "e" @[pos="ADJ.*" \& func!=">N"])|

([lema="ela" \& func="SUBJ>"] [lema="ser|estar"] [pos="ADV.*"]* [temcagr!="."PASS.*" \& pos="ADJ|N|V" \& gen="F" \& func="<SC"] "," @[pos="ADJ.*" \& func!=">N"])|

([sema=".*Pessoa.*" \& func!="P<"] "," [pos="ADV.*"] @ @[func="N<PRED|.*APP.*" \& gen="F" \& pos="ADJ"])|

([sema=".*Pessoa. *" \& func!="P<"] "," [pos="ADV.."]* [func="N<PRED|.*APP.." \& gen="F" \& pos="ADJ"] "e" @[gen="F" \& pos="ADJ"])|

([sema=".*Pessoa.*" \& func!="P<"] "," [pos="ADV.*"]* [func="N<PRED|.*APP.*" \& gen="F" \& pos="ADJ"] "," @[gen="F" \& pos="ADJ"])|

([lema="mulher|moça|rapariga|menina|senhora"] "," [pos="ADV.*"]* @[func="N<PRED|.*APP.*" \& gen="F" \& pos="ADJ"])|

([lema="mulher|moça|rapariga|menina|senhora"] "," [pos="ADV.*"]* [func="N<PRED|. APP.*" \& gen="F" \& pos="ADJ"] "e" @[gen="F" \& pos="ADJ"])|

([lema="mulher|moça|rapariga|menina|senhora"] "," [pos="ADV.*"]* [func="N<PRED|. *APP.*" \& gen="F" \& pos="ADJ"] "," @[gen="F" \& pos="ADJ"])|

([lema="ela" \& func="SUBJ>"] "," [pos="ADV.*"]* [func="N<PRED|.*APP. *" \& gen="F" \& pos="ADJ"] "e" @[gen="F" \& pos="ADJ"])|

([lema="ela" \& func="SUBJ>"] "," [pos="ADV.*"]* [func="N<PRED|. *APP.*" \& gen="F" \& pos="ADJ"] "," @[gen="F" \& pos="ADJ"])| 
([lema="ela" \& func="SUBJ>"] "," [pos="ADV.*"]* @[func="N<PRED|.*APP.*" \& gen="F" \& pos="ADJ"])|

([lema="mulher|moça|rapariga|menina|senhora"] @[pos="N|ADJ|V" \& func="<PRED $|<O C| N<"]) \mid$

([lema="mulher|moça|rapariga|menina|senhora"] [pos="N|ADJ|V" \& func="<PRED $|<O C| N<"]$ "e" @[pos="ADJ" \& gen="F"])|

([lema="mulher|moça|rapariga|menina|senhora"] [pos="N|ADJ|V" \& func="<PRED $|<O C| N<"]$ "," @[pos="ADJ" \& gen="F"])|

([lema="mulher|moça|rapariga|menina|senhora"] [pos="N|ADJ|V" \& func="<PRED $|<O C| N<"]$ "," [pos="ADJ"] "," @[pos="ADJ" \& gen="F"])|

([lema="mulher|moça|rapariga|menina|senhora"] [pos="N|ADJ|V" \& func="<PRED $|<O C| N<"]$ "," [pos="ADJ"] "e" @[pos="ADJ" \& gen="F"])|

([sema="parentesco" \& gen="F"] @[pos="N|ADJ|V" \& func="<PRED $|<O C| N<"])$

\section{Masculino:}

([sema=".*Pessoa.*" \& gen="M" \& func="SUBJ>"] [lema="ser|estar"] [pos="ADV. *"] @[temcagr!=".*PASS.*" \& pos="ADJ|N|V" \& func="<SC"])|

([sema=".*Pessoa.*" \& gen="M" \& func="SUBJ>"] [lema="ser|estar"] [pos="ADV.*"]* [pos="ADJ." \& gen="M" \& func!=">N"]* "e" @[pos="ADJ. *" \& func!=">N"])|

([sema=". *Pessoa. *" \& gen="M" \& func="SUBJ>"] [lema="serlestar"] [pos="ADV. *"] [pos="ADJ.*" \& gen="M" \& func!=">N"]* "," @[pos="ADJ.*" \& func!=">N"])|

([sema="parentesco" \& gen="M" \& func="SUBJ>"] [word="de|do|da"]* [sema="Pessoa"] [lema="ser|estar"] [pos="ADV. *"]* @[temcagr!=".*PASS. *" \& pos="ADJ|N|V" \& func="<SC"])|

([sema="parentesco" \& gen="M" \& func="SUBJ>"] [word="de|do|da"] [sema="Pessoa"] ${ }^{*}$ [lema="ser|estar"] [pos="ADV."]* [pos="ADJ." \& gen="M" \& func!=">N"] "e" @[pos="ADJ.*" \& func!=">N"])|

([sema="parentesco" \& gen="M" \& func="SUBJ>"] [word="de|do|da"] [sema="Pessoa"]* [lema="ser|estar"] [pos="ADV.*"]* [pos="ADJ.*" \& gen="M" \& func!=">N"] "," @[pos="ADJ.*" \& func!=">N"])|

([lema="homem|moço|rapaz|menino|senhor" \& func="SUBJ>"] [lema="ser|estar"] [pos="ADV.*"]* @[temcagr!=".*PASS. *" \& pos="ADJ|N|V" \& func="<SC"])|

([lema="homem|moço|rapaz|menino|senhor" \& func="SUBJ>"] [lema="ser|estar"] [pos="ADV. *"]* [pos="ADJ." \& gen="M" \& func!=">N"] "e" @[pos="ADJ." \& func!=">N"])|

([lema="homem|moço|rapaz|menino|senhor" \& func="SUBJ>"] [lema="ser|estar"] [pos="ADV.*"]* [pos="ADJ.*" \& gen="M" \& func!=">N"] "," @[pos="ADJ. *" \& func!=">N"])|

([lema="ele" \& func="SUBJ>"] [lema="ser|estar"] [pos="ADV.*"] @[temcagr!=".*PASS.*" \& pos="ADJ|N|V" \& func="<SC"])|

([lema="ele" \& func="SUBJ>"] [lema="ser|estar"] [pos="ADV.*"]* [temcagr!="..PASS. *" \& pos="ADJ|N|V" \& gen="M" \& func="<SC"] "e" @[pos="ADJ.*" \& func!=">N"])|

([lema="ele" \& func="SUBJ>"] [lema="ser|estar"] [pos="ADV.*"]* [temcagr!="."PASS.*" \& pos="ADJ|N|V" \& gen="M" \& func="<SC"] "," @[pos="ADJ.*" \& func!=">N"])|

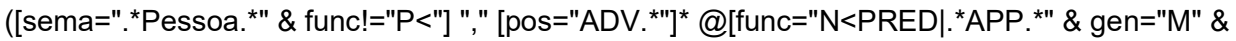
pos="ADJ"])|

([sema=".*Pessoa. *" \& func!="P<"] "," [pos="ADV.*"] [func="N<PRED|. *APP.*" \& gen="M" \& pos="ADJ"] "e" @[gen="M" \& pos="ADJ"])| 


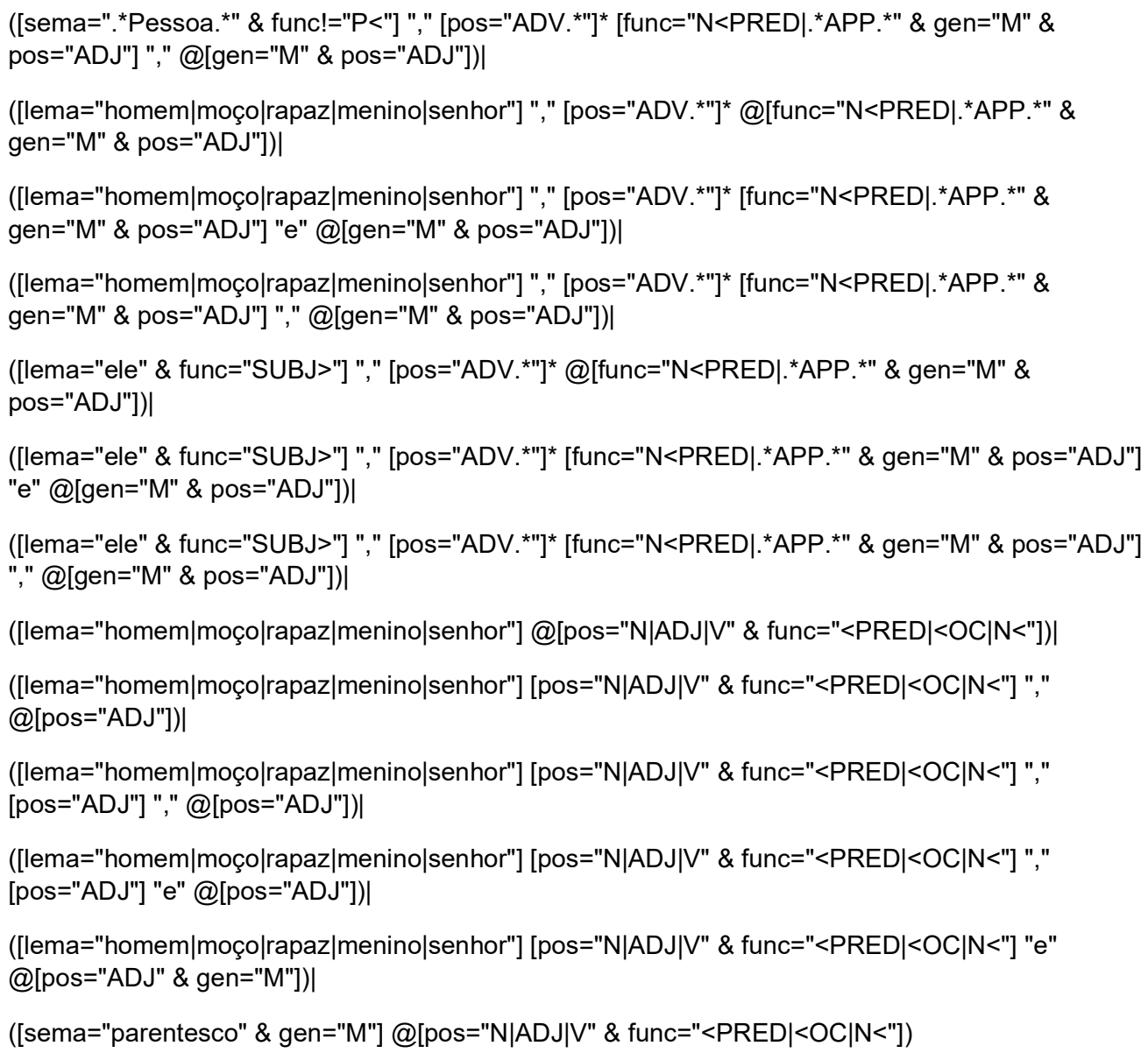




\section{Apêndice 4 - Resultado das buscas por predicadores + categorização}

\begin{tabular}{|c|c|c|c|c|c|c|c|}
\hline Femininos & qtd & & cos & Masculinos & qtd & $\overline{\text { eix }}$ & \\
\hline bonito & 146 & aparência & & loiro & 15 & aparência & \\
\hline belo & 66 & aparência & & sério & 74 & caráter & \\
\hline amado & 43 & emo & & bom & 60 & caráter & \\
\hline casado & 43 & social & & alto & 57 & aparência & \\
\hline formoso & 38 & aparência & & pobre & 46 & social & \\
\hline pálido & 37 & aparência & & rico & 41 & social & \\
\hline honesto & 36 & caráter & & capaz & 40 & caráter & \\
\hline velho & 32 & aparência & & bonito & 34 & aparência & \\
\hline alto & 30 & aparência & & pálido & 32 & aparência & \\
\hline doente & 25 & aparência & & homem & 31 & erro & \\
\hline rico & 24 & social & & cândido & 29 & caráter & \\
\hline bom & 24 & caráter & & forte & 29 & aparência & \\
\hline idoso & 22 & aparência & & moço & 29 & aparência & \\
\hline capaz & 22 & caráter & & mau & 29 & caráter & \\
\hline solteiro & 21 & social & & inteligente & 27 & caráter & \\
\hline moreno & 21 & aparência & & honesto & 27 & caráter & \\
\hline moço & 21 & aparência & & magro & 27 & aparência & \\
\hline pobre & 21 & social & & honrado & 24 & caráter & \\
\hline sentado & 20 & erro & & feliz & 24 & emo & \\
\hline feliz & 19 & emo & & velho & 22 & aparência & \\
\hline lindo & 18 & aparência & & digno & 22 & caráter & \\
\hline perder & 17 & caráter & social & alegre & 22 & emo & \\
\hline encantador & 17 & aparência & & solteiro & 21 & social & \\
\hline feio & 17 & aparência & & grave & 21 & caráter & \\
\hline louro & 26 & aparência & & doente & 21 & aparência & \\
\hline gordo & 16 & aparência & & robusto & 20 & aparência & \\
\hline livre & 15 & caráter & social & público & 20 & social & \\
\hline filha & 15 & social & & gordo & 19 & aparência & \\
\hline alegre & 15 & emo & & cheio & 19 & erro & \\
\hline viúvo & 14 & social & & doido & 18 & caráter & \\
\hline mãe & 14 & social & & fazer & 17 & aparência & \\
\hline branco & 14 & aparência & & branco & 17 & aparência & \\
\hline mulher & 13 & erro & & baixo & 17 & aparência & \\
\hline forte & 12 & aparência & & amigo & 17 & caráter & social \\
\hline cheio & 12 & erro & & morto & 16 & aparência & \\
\hline novo & 12 & aparência & & elegante & 16 & aparência & \\
\hline travesso & 11 & caráter & & casado & 16 & social & \\
\hline puro & 11 & caráter & & valente & 15 & caráter & emo \\
\hline triste & 11 & emo & & filho & 15 & social & \\
\hline amigo & 11 & caráter & social & triste & 14 & emo & \\
\hline radiante & 10 & emo & & novo & 14 & aparência & \\
\hline nu & 10 & aparência & & sentado & 13 & erro & \\
\hline fazer & 10 & aparência & & atônito & 13 & emo & \\
\hline presente & 9 & estado & & nobre & 13 & social & \\
\hline ajoelhado & 9 & erro & & vestir & 13 & aparência & \\
\hline caprichoso & 9 & caráter & & grande & 13 & caráter & \\
\hline coitado & 9 & emo & & contente & 12 & emo & \\
\hline trêmulo & 9 & aparência & emo & generoso & 12 & caráter & \\
\hline só & 9 & social & & vivo & 12 & aparência & \\
\hline magro & 9 & aparência & & respeitável & 11 & emo & \\
\hline assustado & 8 & emo & & vulgar & 11 & caráter & \\
\hline sozinho & 8 & social & & comovido & 11 & emo & \\
\hline gentil & 8 & caráter & & político & 11 & social & \\
\hline inocente & 8 & caráter & & coitado & 11 & emo & \\
\hline impaciente & 8 & caráter & emo & feiticeiro & 10 & social & \\
\hline
\end{tabular}




\begin{tabular}{|c|c|c|c|c|c|c|c|}
\hline & pronto & 8 & estado & calmo & 10 & caráter & \\
\hline & digno & 8 & caráter & ilustre & 10 & caráter & social \\
\hline & sério & 8 & caráter & notável & 10 & social & \\
\hline & distinto & 7 & social & amado & 10 & emo & \\
\hline & brasileiro & 7 & social & frio & 10 & caráter & \\
\hline & viúva & 7 & social & pronto & 10 & estado & \\
\hline & vulgar & 7 & caráter & nu & 10 & aparência & \\
\hline & risonho & 7 & emo & importante & 10 & social & \\
\hline & elegante & 7 & aparência & tímido & 9 & caráter & \\
\hline & vivo & 7 & aparência & capitão & 9 & social & \\
\hline & nervoso & 7 & emo & ausente & 9 & estado & \\
\hline & criança & 7 & aparência & prático & 9 & estado & \\
\hline & fraco & 7 & aparência & prudente & 9 & caráter & \\
\hline & amante & 7 & social & sábio & 9 & caráter & \\
\hline & infeliz & 7 & emo & presente & 9 & estado & \\
\hline & romântico & 6 & caráter & espantado & 9 & emo & \\
\hline & ciumento & 6 & emo & pensativo & 9 & emo & \\
\hline & grávido & 6 & aparência & livre & 9 & caráter & social \\
\hline & espantado & 6 & emo & apaixonado & 9 & emo & \\
\hline & má & 6 & caráter & desconhecido & 9 & social & \\
\hline & comovido & 6 & emo & ansioso & 9 & emo & \\
\hline & inteligente & 6 & caráter & armar & 9 & erro & \\
\hline & faceiro & 6 & aparência emo & fraco & 9 & aparência & \\
\hline & louco & 6 & caráter & absoluto & 9 & caráter & \\
\hline & frio & 6 & caráter & válido & 8 & erro & \\
\hline & sincero & 6 & caráter & maduro & 8 & aparência & \\
\hline & moça & 6 & aparência & português & 8 & social & \\
\hline & vestir & 6 & aparência & moreno & 8 & aparência & \\
\hline & grande & 6 & caráter & virtuoso & 8 & caráter & \\
\hline & namoradeiro & 5 & caráter & radiante & 8 & emo & \\
\hline & maltrapilho & 5 & aparência & risonho & 8 & emo & \\
\hline & fácil & 5 & caráter & direito & 8 & caráter & \\
\hline & vaidoso & 5 & emo & chamado & 8 & erro & \\
\hline & indignado & 5 & emo & silencioso & 8 & caráter & \\
\hline & calado & 5 & caráter & fiel & 8 & caráter & \\
\hline & ambicioso & 5 & caráter & sozinho & 8 & social & \\
\hline & pensativo & 5 & emo & empregado & 8 & social & \\
\hline & indiferente & 5 & caráter & vermelho & 8 & aparência & \\
\hline & esplêndido & 5 & aparência & assim & 8 & erro & \\
\hline & aflito & 5 & emo & malcriado & 7 & caráter & \\
\hline & cego & 5 & aparência & civilizado & 7 & social & \\
\hline & loureira & 5 & caráter & rude & 7 & caráter & emo \\
\hline & adorável & 5 & emo & sertanejo & 7 & social & \\
\hline & fresco & 5 & caráter & teimoso & 7 & caráter & \\
\hline & infame & 5 & caráter & perdido & 9 & caráter & \\
\hline & morto & 5 & aparência & resoluto & 7 & estado & \\
\hline & azul & 5 & aparência & primitivo & 7 & social & \\
\hline & galante & 5 & aparência & simpático & 7 & caráter & \\
\hline & ardente & 5 & aparência emo & imóvel & 7 & estado & \\
\hline & pequeno & 5 & aparência & trêmulo & 7 & aparência & emo \\
\hline & baixo & 5 & aparência & inocente & 7 & caráter & \\
\hline & santo & 5 & caráter & sincero & 7 & caráter & \\
\hline & desmaiado & 4 & estado & pai & 7 & social & \\
\hline & atônito & 4 & emo & simples & 7 & caráter & \\
\hline & tímido & 4 & caráter & feudal & 6 & social & \\
\hline & admirado & 4 & emo & hábil & 6 & caráter & \\
\hline & trabalhadeira & 4 & caráter & ilustrado & 6 & social & \\
\hline & enganado & 4 & estado & entusiasmado & 6 & emo & \\
\hline & tísico & 4 & aparência & preso & 6 & erro & \\
\hline & ausente & 4 & estado & distinto & 6 & social & \\
\hline
\end{tabular}




\begin{tabular}{|c|c|c|c|c|c|c|c|c|}
\hline & incapaz & 4 & estado & & formado & 6 & social & \\
\hline & agradável & 4 & emo & & orgulhoso & 6 & emo & \\
\hline & medroso & 4 & emo & & metido & 6 & caráter & \\
\hline & orgulhoso & 4 & emo & & admirável & 6 & emo & \\
\hline & convencido & 4 & emo & & preocupado & 6 & emo & \\
\hline & agitado & 4 & emo & & negociante & 6 & social & \\
\hline & mudo & 4 & aparência & & ativo & 6 & social & \\
\hline & virtuoso & 4 & caráter & & furioso & 6 & emo & \\
\hline & cansado & 4 & aparência & & amável & 6 & caráter & \\
\hline & choroso & 4 & emo & & enfermo & 6 & aparência & \\
\hline & doido & 4 & caráter & & receoso & 6 & emo & \\
\hline & ignorante & 4 & caráter & & ferido & 6 & estado & \\
\hline & sereno & 4 & aparência & & seguro & 6 & caráter & \\
\hline & enfermo & 4 & aparência & & delicado & 6 & caráter & aparência \\
\hline & discreto & 4 & caráter & & nervoso & 6 & emo & \\
\hline & atento & 4 & caráter & & impaciente & 6 & caráter & emo \\
\hline & curioso & 4 & caráter & & puro & 6 & caráter & \\
\hline & senhora & 4 & caráter & & célebre & 6 & social & \\
\hline & insensível & 4 & caráter & & sagaz & 5 & caráter & \\
\hline & desgraçado & 4 & caráter & emo & morigerado & 5 & caráter & \\
\hline & tranqüilo & 4 & emo & & aturdido & 5 & emo & \\
\hline & ingênuo & 4 & caráter & & excepcional & 5 & caráter & \\
\hline & vermelho & 4 & aparência & & romântico & 5 & caráter & \\
\hline & meigo & 4 & caráter & emo & abastado & 5 & social & \\
\hline & jovem & 4 & aparência & & vaidoso & 5 & emo & \\
\hline & virgem & 4 & social & aparência & corajoso & 5 & emo & \\
\hline & angélico & 4 & caráter & & útil & 5 & caráter & \\
\hline & verdadeiro & 4 & caráter & & sisudo & 5 & caráter & \\
\hline & íntimo & 4 & social & & ruivo & 5 & aparência & \\
\hline & simples & 4 & caráter & & incapaz & 5 & estado & \\
\hline & contentíssimo & 3 & emo & & barbado & 5 & aparência & \\
\hline & másculo & 3 & aparência & & calado & 5 & caráter & \\
\hline & ímpio & 3 & caráter & & oficial & 5 & social & \\
\hline & embriagado & 3 & estado & & ignorante & 5 & caráter & \\
\hline & aturdido & 3 & emo & & lívido & 5 & aparência & \\
\hline & ofendido & 3 & emo & & vadio & 5 & caráter & \\
\hline & corado & 3 & emo & aparência & ébrio & 5 & caráter & aparência \\
\hline & frívolo & 3 & caráter & & cruel & 5 & caráter & emo \\
\hline & guerreiro & 3 & social & & grato & 5 & emo & \\
\hline & excepcional & 3 & caráter & & indiferente & 5 & caráter & emo \\
\hline & primo & 3 & social & & fino & 5 & caráter & \\
\hline & gracioso & 3 & aparência & & perigoso & 5 & social & \\
\hline & surpreso & 3 & emo & & namorado & 5 & emo & social \\
\hline & romanesco & 3 & caráter & & extraordinário & 5 & caráter & \\
\hline & empregada & 3 & social & & ingrato & 5 & emo & \\
\hline & são & 3 & aparência & & poderoso & 5 & social & \\
\hline & apático & 3 & aparência & emo & limpo & 5 & aparência & \\
\hline & trêfego & 3 & caráter & & claro & 5 & aparência & \\
\hline & à-toa & 3 & social & & louco & 5 & caráter & \\
\hline & aborrecido & 3 & emo & & adormecido & 5 & estado & \\
\hline & embebido & 3 & estado & & único & 5 & erro & \\
\hline & ruivo & 3 & aparência & & franco & 5 & caráter & \\
\hline & $\mathrm{m}$ & 3 & erro & & brutal & 5 & caráter & \\
\hline & robusto & 3 & aparência & & religioso & 5 & caráter & \\
\hline & descalço & 3 & aparência & & singular & 5 & caráter & \\
\hline & interessante & 3 & caráter & & desesperado & 5 & emo & \\
\hline & nobre & 3 & social & & belo & 5 & aparência & \\
\hline & esperto & 3 & caráter & & só & 5 & social & \\
\hline & solteira & 3 & social & & feio & 5 & aparência & \\
\hline
\end{tabular}




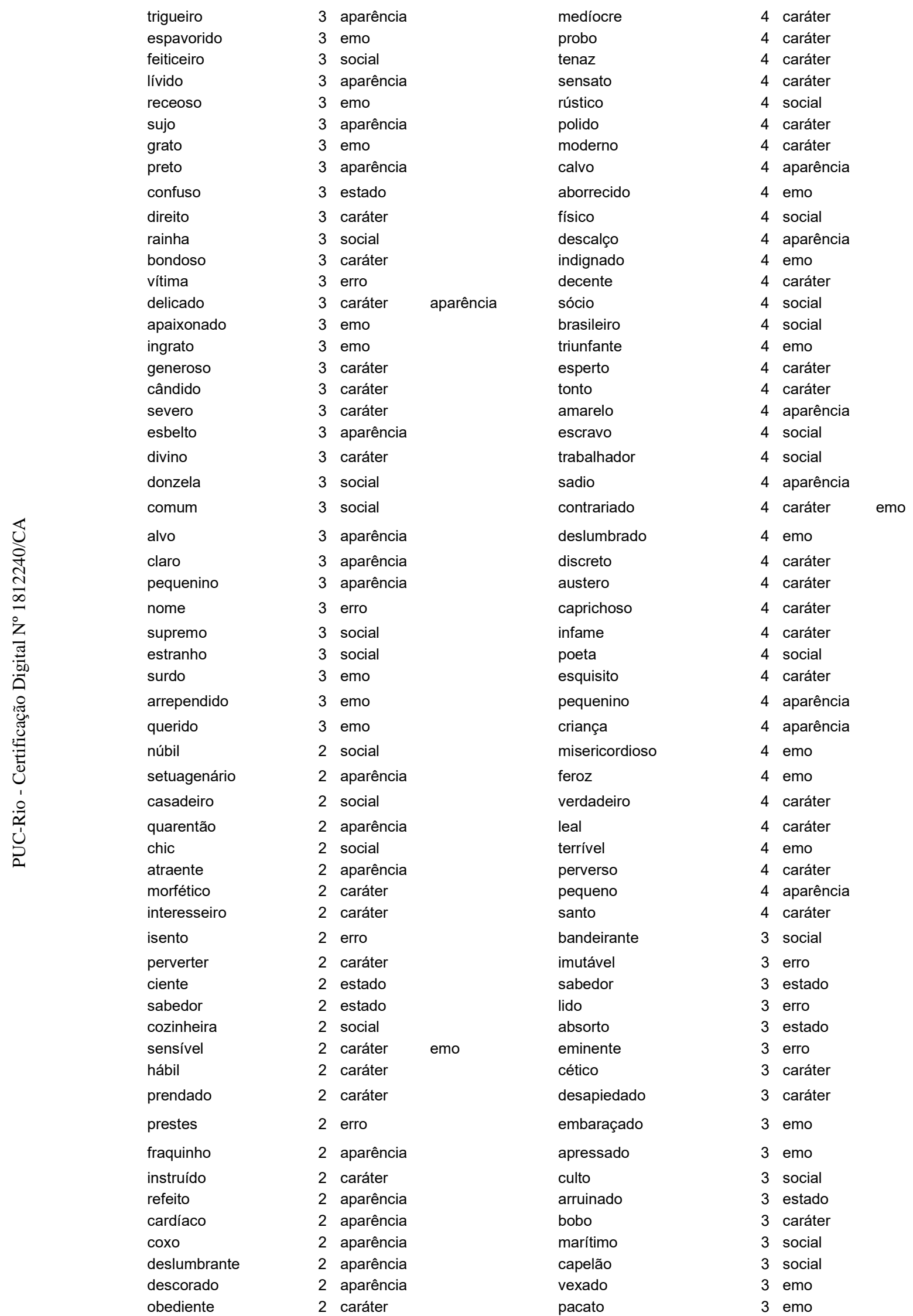




\begin{tabular}{|c|c|c|c|c|c|c|c|c|}
\hline & suspeito & 2 & estado & & apreensivo & 3 & emo & \\
\hline & acanhado & 2 & emo & & lépido & 3 & caráter & \\
\hline & parenta & 2 & social & & educado & 3 & caráter & \\
\hline & riquíssimo & 2 & social & & insinuante & 3 & caráter & \\
\hline & desvalido & 2 & social & & indigno & 3 & caráter & \\
\hline & rebelde & 2 & caráter & & engenheiro & 3 & social & \\
\hline & inflexível & 2 & caráter & & surpreso & 3 & emo & \\
\hline & bem-educado & 2 & caráter & & ríspido & 3 & caráter & \\
\hline & seminu & 2 & aparência & & travesso & 3 & caráter & \\
\hline & desgrenhado & 2 & aparência & & idoso & 3 & aparência & \\
\hline & inglês & 2 & social & & admirado & 3 & emo & \\
\hline & impertinente & 2 & caráter & & jornalista & 3 & social & \\
\hline & afogueado & 2 & emo & & hediondo & 3 & emo & \\
\hline & sóbrio & 2 & caráter & & viúvo & 3 & social & \\
\hline & amuado & 2 & emo & & baixinho & 3 & aparência & \\
\hline & sôfrego & 2 & emo & & volúvel & 3 & caráter & \\
\hline & inquieto & 2 & emo & & circunspeto & 3 & caráter & \\
\hline & prudente & 2 & caráter & & destemido & 3 & emo & \\
\hline & rubro & 2 & aparência & & impassível & 3 & emo & \\
\hline & sacudido & 2 & estado & & teso & 3 & aparência & \\
\hline & respeitável & 2 & emo & & vigoroso & 3 & caráter & \\
\hline & volúvel & 2 & caráter & & excelente & 3 & caráter & \\
\hline & despido & 2 & aparência & & juiz & 3 & social & \\
\hline & destemido & 2 & emo & & grosseiro & 3 & caráter & emo \\
\hline & zeloso & 2 & caráter & & insuportável & 3 & caráter & \\
\hline & lânguido & 2 & aparência & caráter & trigueiro & 3 & aparência & \\
\hline & idiota & 2 & caráter & & expansivo & 3 & caráter & \\
\hline & franzino & 2 & aparência & & macilento & 3 & aparência & \\
\hline & curiosa & 2 & caráter & & deitado & 3 & estado & \\
\hline & tolo & 2 & caráter & & ambicioso & 3 & caráter & \\
\hline & malicioso & 2 & caráter & & zangado & 3 & emo & \\
\hline & metido & 2 & caráter & & soldado & 3 & social & \\
\hline & bastardo & 2 & caráter & & ruim & 3 & caráter & emo \\
\hline & preocupado & 2 & emo & & ai & 3 & erro & \\
\hline & leviano & 2 & caráter & & insolente & 3 & emo & \\
\hline & desquitado & 2 & social & & bravo & 3 & EMO & \\
\hline & agradecido & 2 & emo & & necessário & 3 & erro & \\
\hline & afável & 2 & caráter & & criminoso & 3 & social & \\
\hline & expansivo & 2 & caráter & & irritado & 3 & emo & \\
\hline & imprudente & 2 & caráter & & altivo & 3 & emo & \\
\hline & verde & 2 & aparência & & melancólico & 3 & emo & \\
\hline & cônscio & 2 & estado & & desvairado & 3 & caráter & \\
\hline & sucumbido & 2 & emo & & nascer & 3 & erro & \\
\hline & escravo & 2 & social & & cego & 3 & aparência & \\
\hline & histérico & 2 & caráter & & deus & 3 & erro & \\
\hline & estendido & 2 & estado & & artista & 3 & social & \\
\hline & prostrado & 2 & estado & & social & 3 & erro & \\
\hline & contrariado & 2 & caráter & emo & fatal & 3 & erro & \\
\hline & vadio & 2 & caráter & & pasmado & 3 & emo & \\
\hline & acordado & 2 & estado & & curioso & 3 & caráter & \\
\hline & calmo & 2 & caráter & & criado & 3 & erro & \\
\hline & noiva & 2 & social & & humilde & 3 & emo & \\
\hline & covarde & 2 & caráter & & maravilhado & 3 & emo & \\
\hline & espanhol & 2 & social & & severo & 3 & caráter & \\
\hline & criminoso & 2 & social & & rijo & 3 & aparência & \\
\hline & irritado & 2 & emo & & esbelto & 3 & aparência & \\
\hline & grave & 2 & caráter & & rapaz & 3 & aparência & \\
\hline
\end{tabular}




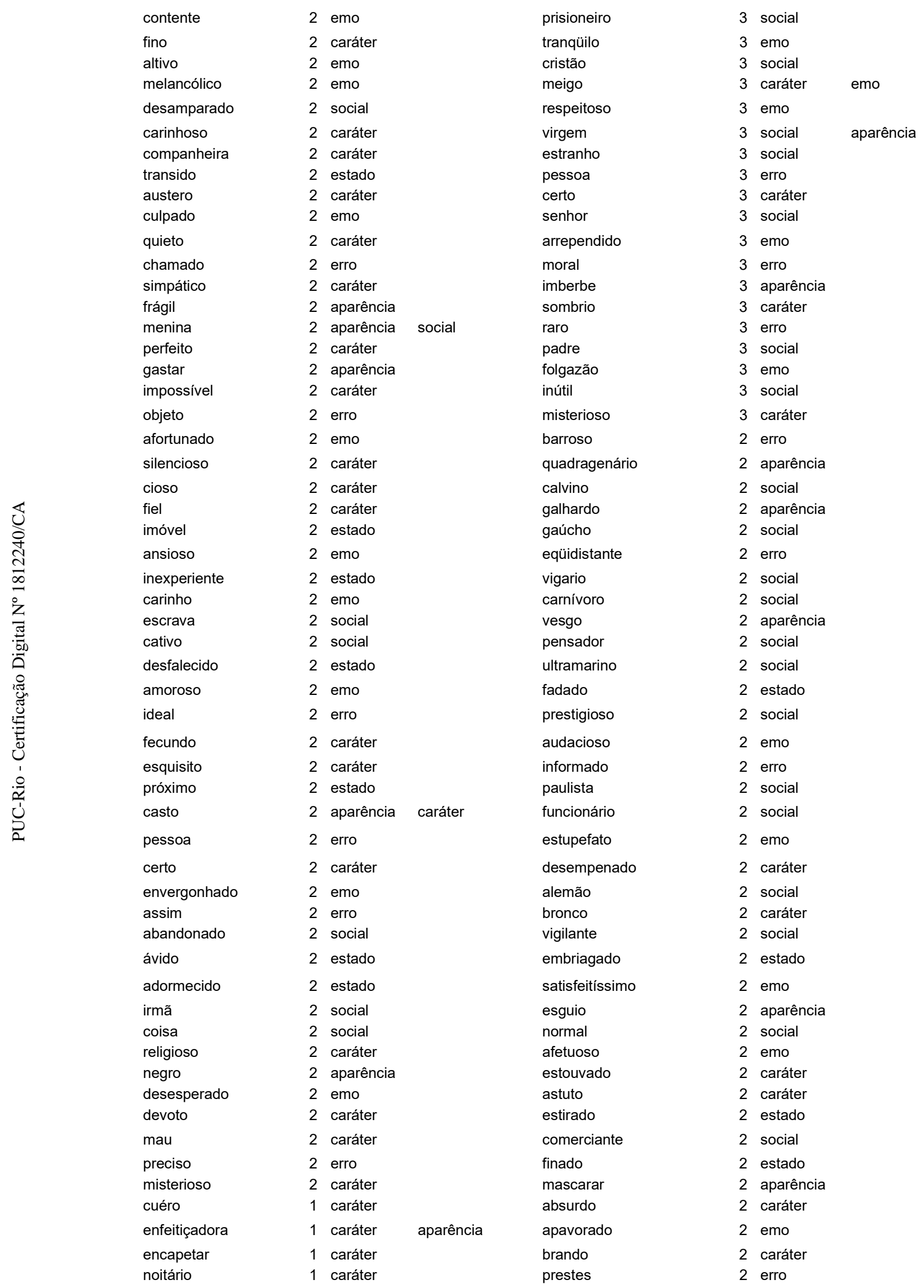




\begin{tabular}{|c|c|c|c|c|c|c|c|}
\hline pequenota & 1 & aparência & & acadêmico & 2 & social & \\
\hline assoluto & 1 & caráter & & estudioso & 2 & caráter & social \\
\hline pechoso & 1 & caráter & & exemplar & 2 & caráter & \\
\hline valentino & 1 & erro & & romancista & 2 & social & \\
\hline loresce & 1 & erro & & instruído & 2 & caráter & \\
\hline paranaense & 1 & social & & imortal & 2 & caráter & \\
\hline brabinho & 1 & caráter & emo & encolhido & 2 & aparência & \\
\hline cheinha & 1 & aparência & & fiado & 2 & erro & \\
\hline tuxaua & 1 & social & & incorrigível & 2 & caráter & \\
\hline zangadíssimo & 1 & emo & & solícito & 2 & caráter & \\
\hline schwester & 1 & erro & & encaminhar & 2 & erro & \\
\hline graciosíssimo & 1 & aparência & & excêntrico & 2 & caráter & \\
\hline deliciosíssimo & 1 & aparência & & obediente & 2 & caráter & \\
\hline desventuroso & 1 & emo & & passageiro & 2 & social & \\
\hline impressível & 1 & caráter & & irascível & 2 & caráter & \\
\hline leso & 1 & erro & & desinteressado & 2 & estado & \\
\hline imaginativo & 1 & caráter & & laborioso & 2 & caráter & \\
\hline norueguês & 1 & social & & esquecido & 2 & estado & \\
\hline sensaborona & 1 & aparência & & cauteloso & 2 & caráter & \\
\hline hebdomadário & 1 & erro & & acanhado & 2 & emo & \\
\hline valsista & 1 & social & & pacífico & 2 & caráter & social \\
\hline fadista & 1 & social & & afoito & 2 & emo & \\
\hline marvado & 1 & caráter & & econômico & 2 & social & \\
\hline poetisa & 1 & social & & diretor & 2 & social & \\
\hline despropositado & 1 & caráter & & penetrante & 2 & erro & \\
\hline falsária & 1 & caráter & & diferente & 2 & estado & \\
\hline adiantado $=\mathrm{em}=$ anos & 1 & aparência & & saído & 2 & erro & \\
\hline mezinheiras & 1 & social & & europeu & 2 & erro & \\
\hline bonitinhas & 1 & aparência & & atrapalhado & 2 & caráter & \\
\hline desprezável & 1 & caráter & & preparado & 2 & erro & \\
\hline mariano & 1 & erro & & deputado & 2 & social & \\
\hline altinho & 1 & aparência & & dedicado & 2 & caráter & \\
\hline sabichona & 1 & caráter & & desempregado & 2 & social & \\
\hline ultrapassado & 1 & estado & & providencial & 2 & erro & \\
\hline semita & 1 & social & & brioso & 2 & aparência & \\
\hline estrábico & 1 & aparência & & maníaco & 2 & caráter & \\
\hline presunçoso & 1 & caráter & & esbaforido & 2 & erro & \\
\hline conversadeiras & 1 & caráter & & alvoroçado & 2 & emo & \\
\hline esporádico & 1 & erro & & turbulento & 2 & caráter & \\
\hline lady=Macbeth & 1 & erro & & liberal & 2 & caráter & \\
\hline agastado & 1 & emo & & sóbrio & 2 & caráter & \\
\hline avantajado & 1 & aparência & & supersticioso & 2 & caráter & \\
\hline ciumentíssimo & 1 & emo & & selvagem & 2 & social & \\
\hline fêmeo & 1 & aparência & & feminino & 2 & caráter & \\
\hline pundonoroso & 1 & caráter & & incomodado & 2 & estado & \\
\hline inteligentíssimo & 1 & caráter & & sacudido & 2 & estado & \\
\hline embriagante & 1 & aparência & caráter & convidado & 2 & erro & \\
\hline $\mathrm{de}=$ siso & 1 & caráter & & derreado & 2 & estado & \\
\hline acostu & 1 & erro & & ágil & 2 & aparência & \\
\hline leiteiro & 1 & social & & tisnado & 2 & aparência & \\
\hline recém-aparecer & 1 & estado & & benfazejo & 2 & caráter & \\
\hline inocentinho & 1 & caráter & & respeitado & 2 & social & \\
\hline brigado & 1 & erro & & metódico & 2 & caráter & \\
\hline bulhento & 1 & caráter & & guloso & 2 & caráter & \\
\hline deficientíssimo & 1 & erro & & miúdo & 2 & aparência & \\
\hline
\end{tabular}




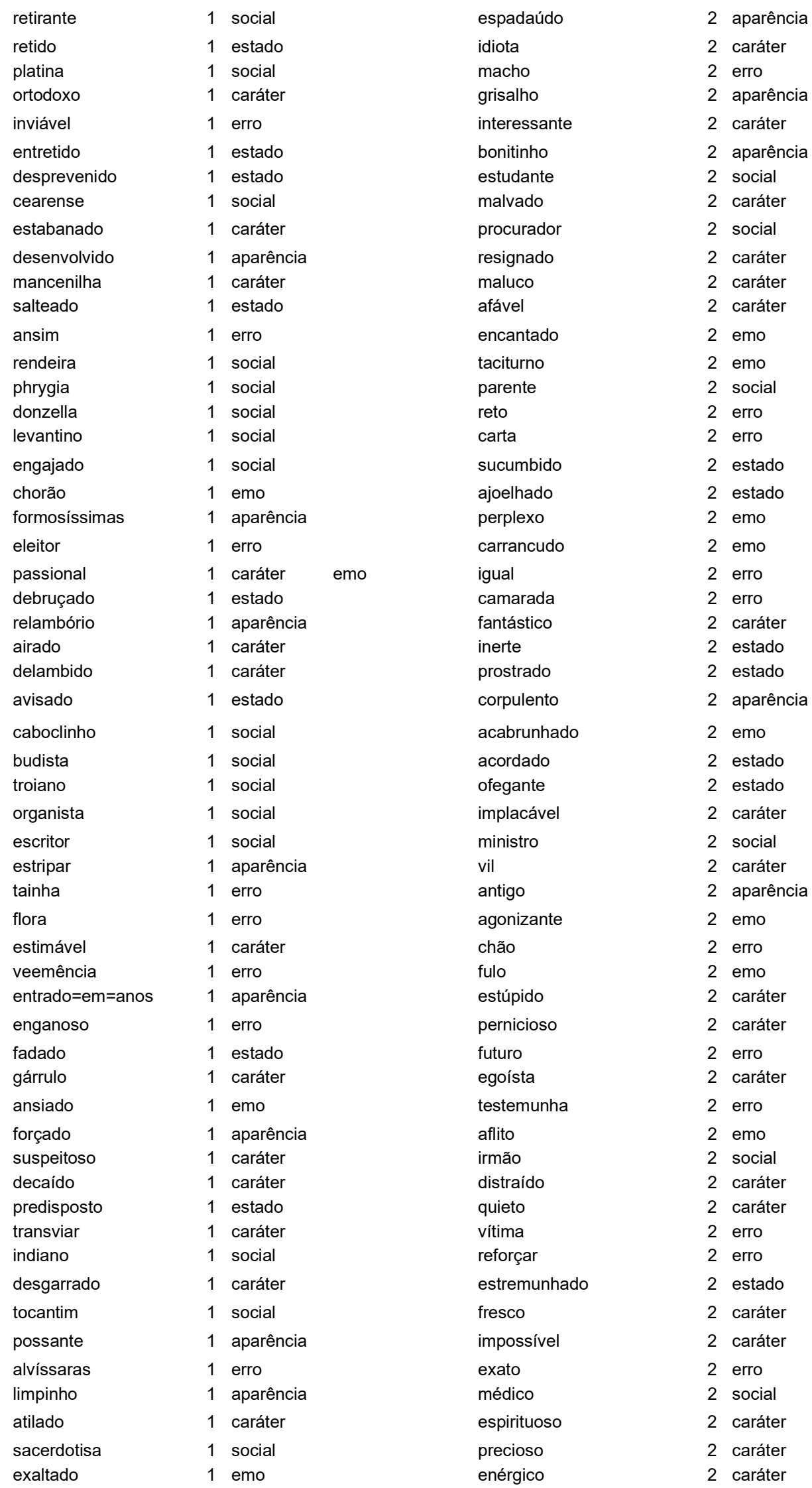




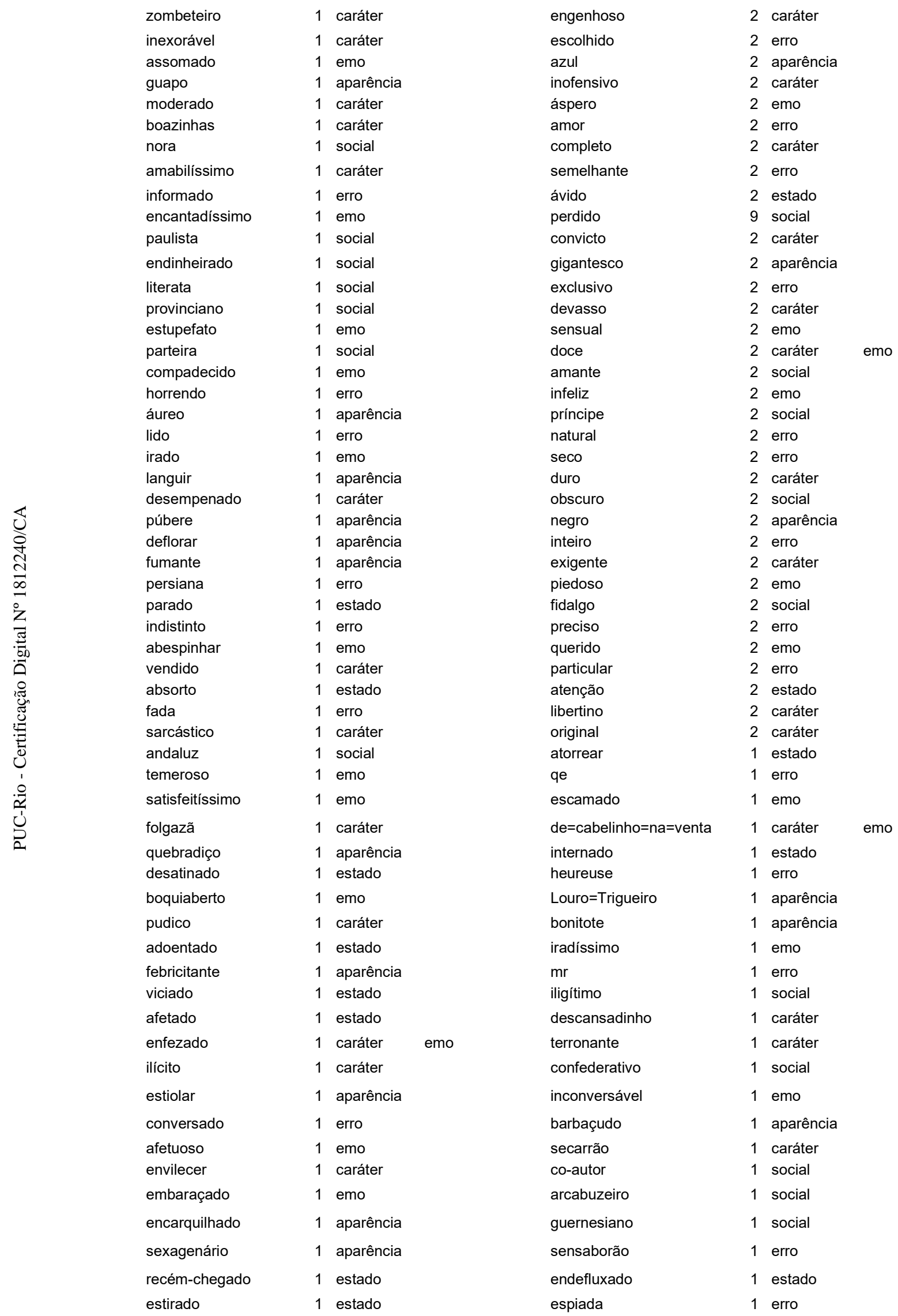




\begin{tabular}{|c|c|c|c|c|c|c|c|}
\hline & insaciável & 1 & caráter & & entretidíssimo & 1 & estado \\
\hline & comerciante & 1 & social & & argumentador & 1 & caráter \\
\hline & degradar & 1 & emo & & javanês & 1 & social \\
\hline & odioso & 1 & emo & & desinfeliz & 1 & emo \\
\hline & esquelético & 1 & aparência & & zangadíssimo & 1 & emo \\
\hline & desenvolto & 1 & caráter & & tiririca & 1 & emo \\
\hline & feioso & 1 & aparência & & carlo & 1 & erro \\
\hline & finado & 1 & estado & & dobradiço & 1 & caráter \\
\hline & horrorizar & 1 & emo & & $\mathrm{de}=$ ponto $=\mathrm{em}=$ branco & 1 & erro \\
\hline & apavorado & 1 & emo & & canhoto & 1 & aparência \\
\hline & bobo & 1 & caráter & & ilegível & 1 & erro \\
\hline & esverdeado & 1 & erro & & desambicioso & 1 & caráter \\
\hline & emocionado & 1 & emo & & qualificado & 1 & social \\
\hline & ateniense & 1 & aparência & & atrapa-Ihado & 1 & caráter \\
\hline & despeitar & 1 & caráter & & casadoiro & 1 & social \\
\hline & moca & 1 & erro & & gelatinoso & 1 & aparência \\
\hline & temente & 1 & caráter & & mesuroso & 1 & caráter \\
\hline & desfeito & 1 & estado & & semi-embriagado & 1 & social \\
\hline & alfenim & 1 & aparência & & bem-comportado & 1 & caráter \\
\hline & sarmento & 1 & erro & & declamador & 1 & caráter \\
\hline & estudioso & 1 & caráter & social & arrieiro & 1 & social \\
\hline & exemplar & 1 & caráter & & indócil & 1 & emo \\
\hline & ufano & 1 & caráter & & parecido & 1 & erro \\
\hline & concho & 1 & erro & & lembrado & 1 & social \\
\hline & maternidade & 1 & caráter & & bem-criado & 1 & social \\
\hline & neta & 1 & social & & rabujento & 1 & caráter \\
\hline 20 & benigno & 1 & caráter & & doidinho & 1 & caráter \\
\hline 6 & descabelado & 1 & aparência & & quaternário & 1 & social \\
\hline & aflautar & 1 & erro & & mortinho & 1 & estado \\
\hline & envenenar & 1 & erro & & empolgado & 1 & estado \\
\hline 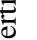 & baixota & 1 & aparência & & poupado & 1 & erro \\
\hline & fementido & 1 & caráter & & dentista & 1 & social \\
\hline & imortal & 1 & caráter & & casadeiro & 1 & social \\
\hline & varonil & 1 & aparência & caráter & citável & 1 & caráter \\
\hline & planície & 1 & erro & & reservadíssimo & 1 & caráter \\
\hline & japonês & 1 & social & & espertalhão & 1 & caráter \\
\hline & irritação & 1 & emo & & contorsionar & 1 & estado \\
\hline & desenganado & 1 & emo & & encobrear & 1 & aparência \\
\hline & extremoso & 1 & emo & & eterômano & 1 & social \\
\hline & lendário & 1 & caráter & & refinado & 1 & caráter \\
\hline & velado & 1 & caráter & & capitáo-mor & 1 & social \\
\hline & formosíssimo & 1 & aparência & & valente $=$ como $=a s=$ armas & 1 & erro \\
\hline & encolhido & 1 & aparência & & fujão & 1 & caráter \\
\hline & uno & 1 & estado & & apaixonadíssimo & 1 & emo \\
\hline & despreocupado & 1 & caráter & & casadinho & 1 & social \\
\hline & patriótico & 1 & social & & lavadinho & 1 & estado \\
\hline & tapageuse & 1 & erro & & ocupadíssimo & 1 & social \\
\hline & vencedor & 1 & social & & pautado & 1 & caráter \\
\hline & inventivo & 1 & erro & & regenerado & 1 & aparência \\
\hline & lépido & 1 & caráter & & ilusionista & 1 & social \\
\hline & experiente & 1 & social & & viajado & 1 & social \\
\hline & ilustrado & 1 & social & & inteligentíssimo & 1 & caráter \\
\hline & habilidoso & 1 & caráter & social & contentíssimo & 1 & emo \\
\hline
\end{tabular}




\begin{tabular}{|c|c|c|c|c|c|c|c|c|}
\hline & pagão & 1 & caráter & & gentleman & 1 & caráter & \\
\hline & grandioso & 1 & caráter & & detido & 1 & estado & \\
\hline & favorável & 1 & erro & & inábil & 1 & social & \\
\hline & dócil & 1 & caráter & & soberbõe & 1 & erro & \\
\hline & impressionável & 1 & caráter & & semi-branco & 1 & aparência & \\
\hline & educado & 1 & caráter & & sargento-mór & 1 & social & \\
\hline & intrometido & 1 & caráter & & dorminhoco & 1 & caráter & \\
\hline & jeitoso & 1 & aparência & caráter & pacífi & 1 & erro & \\
\hline & cigano & 1 & social & & dignificar & 1 & social & \\
\hline & irônico & 1 & caráter & & opilado & 1 & erro & \\
\hline & arrepiado & 1 & emo & & atreito & 1 & erro & \\
\hline & constipado & 1 & estado & & guindado & 1 & social & \\
\hline & doentio & 1 & caráter & & corcunda & 1 & aparência & \\
\hline & prima & 1 & social & & equipado & 1 & estado & \\
\hline & sensato & 1 & caráter & & lugar-tenente & 1 & social & \\
\hline & vestidinho & 1 & aparência & & recalcitrante & 1 & caráter & \\
\hline & crédulo & 1 & caráter & & emérito & 1 & caráter & social \\
\hline & despenteado & 1 & aparência & & desengonçado & 1 & aparência & \\
\hline & indigno & 1 & caráter & & pré-histórico & 1 & aparência & \\
\hline & conhecido & 1 & social & & aceitável & 1 & social & \\
\hline & árabe & 1 & social & & coligar & 1 & social & \\
\hline & fanático & 1 & caráter & & canonizar & 1 & social & \\
\hline & ríspido & 1 & caráter & & seringueiro & 1 & social & \\
\hline & saturar & 1 & erro & & afluente & 1 & erro & \\
\hline & afidalgado & 1 & social & & previdente & 1 & caráter & \\
\hline & loquaz & 1 & caráter & & agitante & 1 & estado & \\
\hline & desvelado & 1 & caráter & & matemático & 1 & social & \\
\hline & colegial & 1 & social & & idealista & 1 & caráter & \\
\hline & zombaria & 1 & erro & & ilógico & 1 & caráter & \\
\hline & metediço & 1 & caráter & & agente $=\mathrm{de}=$ polícia & 1 & social & \\
\hline & carioca & 1 & social & & promíscuo & 1 & caráter & \\
\hline & indiscreto & 1 & caráter & & beneficente & 1 & caráter & \\
\hline & abjeto & 1 & caráter & & timorato & 1 & caráter & \\
\hline & andrajoso & 1 & social & & clemente & 1 & caráter & \\
\hline & mestra & 1 & social & & coevo & 1 & social & \\
\hline & suíço & 1 & social & & alegrete & 1 & emo & \\
\hline & lindíssimo & 1 & aparência & & ex-soldado & 1 & social & \\
\hline & despachado & 1 & caráter & & paraibano & 1 & social & \\
\hline & familiar & 1 & social & & cearense & 1 & social & \\
\hline & sobranceiro & 1 & emo & & desenvolvido & 1 & aparência & \\
\hline & avinhado & 1 & estado & & pegá & 1 & erro & \\
\hline & desperdiçado & 1 & caráter & & condoído & 1 & emo & \\
\hline & vicioso & 1 & caráter & & sinão & 1 & erro & \\
\hline & deleitoso & 1 & aparência & & $\mathrm{im}$ & 1 & erro & \\
\hline & desconfiado & 1 & caráter & emo & acobreado & 1 & aparência & \\
\hline & confundido & 1 & estado & & christão & 1 & social & \\
\hline & indefeso & 1 & caráter & & melancolico & 1 & emo & \\
\hline & espancar & 1 & estado & & gageiro & 1 & social & \\
\hline & demonstração & 1 & erro & & acionista & 1 & social & \\
\hline & abastado & 1 & social & & voluntarioso & 1 & emo & \\
\hline & dedicado & 1 & caráter & & preparatoriano & 1 & social & \\
\hline & garrulo & 1 & caráter & & insatisfeito & 1 & emo & \\
\hline & alemã & 1 & social & & friorento & 1 & aparência & \\
\hline & impudico & 1 & caráter & & parlamentar & 1 & social & \\
\hline
\end{tabular}




\begin{tabular}{|c|c|c|c|c|c|c|c|c|}
\hline & tolinho & 1 & caráter & & considerado & 1 & erro & \\
\hline & instintivo & 1 & erro & & conterrãneo & 1 & social & \\
\hline & gira & 1 & aparência & & cum & 1 & erro & \\
\hline & útil & 1 & erro & & reumático & 1 & aparência & \\
\hline & acocorar & 1 & estado & & estelionatário & 1 & caráter & social \\
\hline & civilizado & 1 & social & & montanhês & 1 & social & \\
\hline & calçado & 1 & aparência & & anão & 1 & aparência & \\
\hline & cavaleira & 1 & social & & paralela & 1 & erro & \\
\hline & amaro & 1 & erro & & interesseiro & 1 & caráter & \\
\hline & vivaz & 1 & caráter & & predestinar & 1 & caráter & \\
\hline & ajuizado & 1 & caráter & & suburbano & 1 & social & \\
\hline & prático & 1 & estado & & avisado & 1 & estado & \\
\hline & ídolo & 1 & erro & & culminante & 1 & erro & \\
\hline & sisudo & 1 & caráter & & banhista & 1 & social & \\
\hline & turbulento & 1 & caráter & & ventrudo & 1 & aparência & \\
\hline & sertanejo & 1 & social & & compenetrado & 1 & caráter & \\
\hline & poético & 1 & aparência & & diminuto & 1 & aparência & \\
\hline & físico & 1 & erro & & chocho & 1 & social & \\
\hline & mineiro & 1 & social & & neutro & 1 & social & \\
\hline & imprevidente & 1 & caráter & & cíclico & 1 & caráter & \\
\hline & autoritário & 1 & caráter & & inverossímil & 1 & caráter & \\
\hline 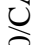 & pertencente & 1 & erro & & pançudo & 1 & aparência & \\
\hline ๙ & melhorzinho & 1 & estado & & zonzo & 1 & aparência & \\
\hline ภ & lisonjear & 1 & emo & & escritor & 1 & social & \\
\hline$\underline{\alpha}$ & contrafeito & 1 & estado & & radioso & 1 & emo & \\
\hline 吕 & esquivo & 1 & caráter & & minúsculo & 1 & aparência & \\
\hline. & sonso & 1 & caráter & & esgalgado & 1 & aparência & \\
\hline$\ddot{0}$ & desacompanhado & 1 & estado & & premiado & 1 & social & \\
\hline శ్తి & ressentir & 1 & emo & & despótico & 1 & social & \\
\hline שֶ & manso & 1 & caráter & & endurecer & 1 & caráter & \\
\hline 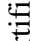 & fanado & 1 & caráter & aparência & vaqueiro & 1 & social & \\
\hline 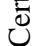 & bêbedo & 1 & estado & & sofrido & 1 & emo & \\
\hline 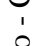 & trunfo & 1 & erro & & fremente & 1 & emo & \\
\hline 2 & convidado & 1 & erro & & pusilânime & 1 & emo & \\
\hline ن & derreado & 1 & estado & & réprobo & 1 & caráter & \\
\hline$\hat{\alpha}$ & velhinho & 1 & aparência & & flagelado & 1 & social & \\
\hline & chique & 1 & aparência & & corrosivo & 1 & caráter & \\
\hline & cerimonioso & 1 & caráter & & proeminente & 1 & social & \\
\hline & metido $=$ consigo & 1 & caráter & & ansiado & 1 & emo & \\
\hline & marciano & 1 & erro & & desazado & 1 & caráter & \\
\hline & estrangeiro & 1 & social & & cenobita & 1 & caráter & social \\
\hline & sossegado & 1 & caráter & & perverter & 1 & caráter & \\
\hline & diligente & 1 & caráter & & excluir & 1 & estado & \\
\hline & simplicidade & 1 & emo & & quedo & 1 & estado & \\
\hline & desassombrado & 1 & emo & & ambíguo & 1 & caráter & \\
\hline & iluminado & 1 & caráter & & inebriante & 1 & aparência & \\
\hline & relativo & 1 & erro & & valoroso & 1 & caráter & \\
\hline & espigado & 1 & aparência & & audaz & 1 & emo & \\
\hline & importuno & 1 & caráter & & bronzeado & 1 & aparência & \\
\hline & assanhado & 1 & caráter & & merencório & 1 & emo & \\
\hline & triunfante & 1 & emo & & canoeiro & 1 & social & \\
\hline & mole & 1 & caráter & & mateiro & 1 & social & \\
\hline & magrinho & 1 & aparência & & endiabrado & 1 & caráter & \\
\hline & titular & 1 & social & & desordeiro & 1 & caráter & \\
\hline & desembaraçado & 1 & caráter & & agilíssimo & 1 & caráter & \\
\hline
\end{tabular}




\begin{tabular}{|c|c|c|c|c|c|c|}
\hline mal-educado & 1 & caráter & & mutilar & 1 & aparência \\
\hline grosseiro & 1 & caráter & emo & possante & 1 & aparência \\
\hline preguiçoso & 1 & estado & & divertido & 1 & caráter \\
\hline lavadeira & 1 & social & & propenso & 1 & erro \\
\hline garantir & 1 & caráter & & exilar & 1 & social \\
\hline inteirinho & 1 & aparência & & rojar & 1 & estado \\
\hline ordinário & 1 & caráter & & jovial & 1 & emo \\
\hline barato & 1 & caráter & & atilado & 1 & caráter \\
\hline propriedade & 1 & social & & plácido & 1 & emo \\
\hline admirável & 1 & emo & & jurisconsulto & 1 & social \\
\hline teimoso & 1 & caráter & & bacharel & 1 & social \\
\hline escrupuloso & 1 & caráter & & determinado & 1 & CARÁTER \\
\hline passivo & 1 & caráter & & exaltado & 1 & emo \\
\hline ativo & 1 & social & & execrando & 1 & ERRO \\
\hline direto & 1 & caráter & & beiçudo & 1 & aparência \\
\hline maluco & 1 & caráter & & tagarela & 1 & caráter \\
\hline órfã & 1 & social & & enfadado & 1 & EMO \\
\hline delgado & 1 & aparência & & inexorável & 1 & caráter \\
\hline gêmeo & 1 & social & & assomado & 1 & emo \\
\hline encantado & 1 & emo & & repulsivo & 1 & aparência \\
\hline anônimo & 1 & social & & cultor & 1 & social \\
\hline iludir & 1 & caráter & & moralista & 1 & caráter \\
\hline abatir & 1 & aparência & & libertar & 1 & ERRO \\
\hline ilusão & 1 & erro & & rabugento & 1 & caráter \\
\hline invejoso & 1 & emo & & libidinoso & 1 & caráter \\
\hline sonâmbulo & 1 & erro & & guapo & 1 & aparência \\
\hline sossegar & 1 & caráter & & moderado & 1 & caráter \\
\hline perdido & 1 & caráter & & urubu & 1 & erro \\
\hline macilento & 1 & aparência & & amabilíssimo & 1 & caráter \\
\hline italiano & 1 & social & & total & 1 & erro \\
\hline sentimental & 1 & caráter & social & sedicioso & 1 & caráter \\
\hline trajar & 1 & aparência & & sangrado & 1 & aparência \\
\hline precoce & 1 & aparência & & castelhano & 1 & social \\
\hline apercebido & 1 & aparência & & tardo & 1 & caráter \\
\hline mimoso & 1 & aparência & & contemporâneo & 1 & caráter \\
\hline tai & 1 & erro & & furibundo & 1 & emo \\
\hline submisso & 1 & caráter & & inerme & 1 & caráter \\
\hline fúria & 1 & emo & & literato & 1 & social \\
\hline usurário & 1 & caráter & & arredio & 1 & caráter \\
\hline amarelo & 1 & aparência & & aplicado & 1 & caráter \\
\hline resoluto & 1 & estado & & aliviado & 1 & emo \\
\hline impuro & 1 & caráter & & exasperadíssimo & 1 & emo \\
\hline perturbado & 1 & estado & & encasacado & 1 & estado \\
\hline carta & 1 & erro & & caipora & 1 & caráter \\
\hline cabisbaixo & 1 & emo & & irritadíssimo & 1 & emo \\
\hline perplexo & 1 & emo & & vendar & 1 & estado \\
\hline enternecer & 1 & emo & & compadecido & 1 & emo \\
\hline prostituir & 1 & social & & magistrado & 1 & social \\
\hline igual & 1 & erro & & crasso & 1 & caráter \\
\hline diverso & 1 & estado & & avaro & 1 & caráter \\
\hline pedido & 1 & social & & irado & 1 & emo \\
\hline tênue & 1 & aparência & & adulto & 1 & erro \\
\hline vaporoso & 1 & aparência & & erigir & 1 & estado \\
\hline vasto & 1 & erro & & levado & 1 & erro \\
\hline infernal & 1 & caráter & & espertinho & 1 & caráter \\
\hline raptar & 1 & estado & & agressivo & 1 & emo \\
\hline deitar & 1 & estado & & bonachão & 1 & caráter \\
\hline inanimado & 1 & caráter & & inválido & 1 & aparência \\
\hline
\end{tabular}




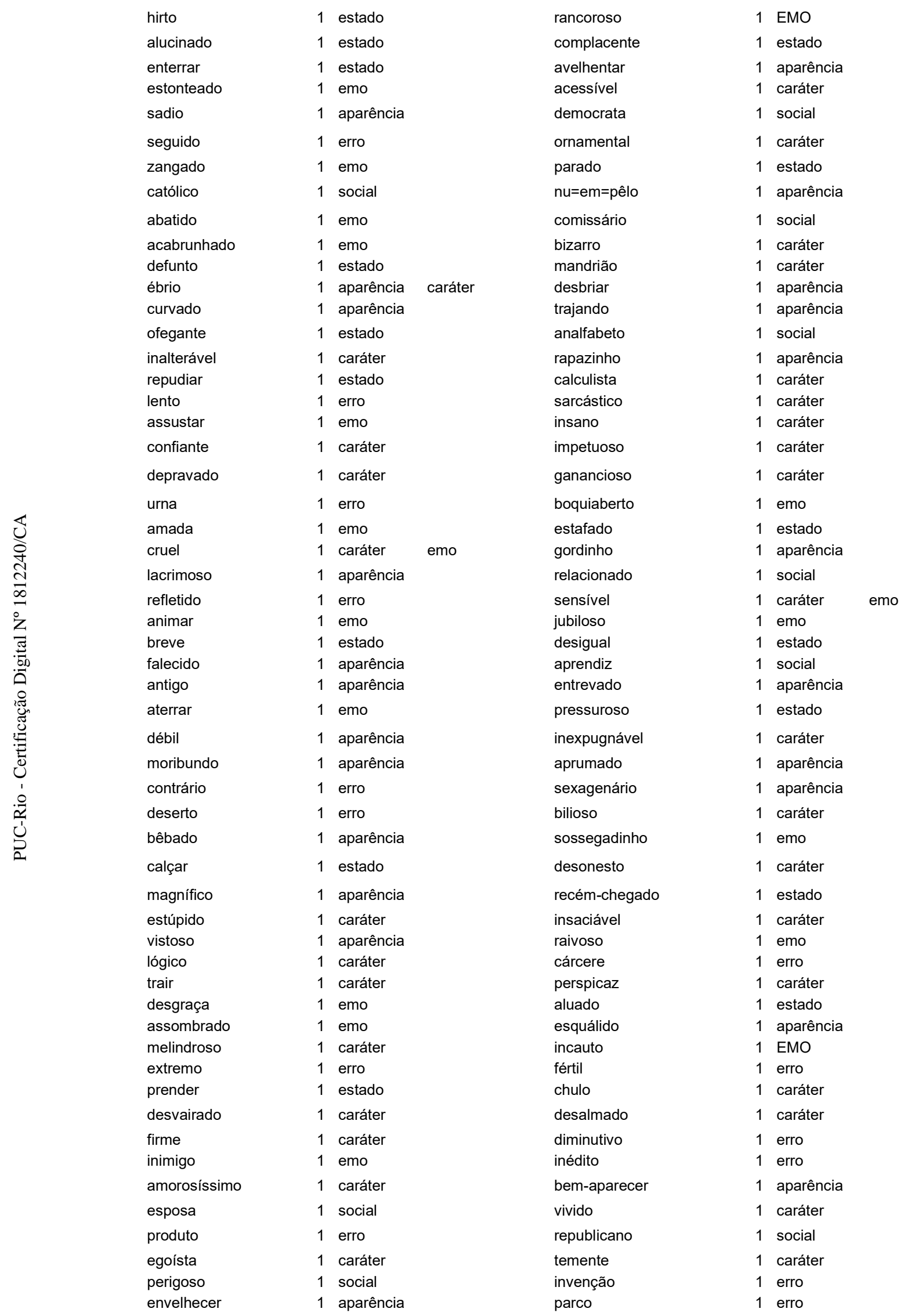




\begin{tabular}{|c|c|c|c|c|c|c|c|}
\hline irresistível & 1 & caráter & aparência & piloto & 1 & social & \\
\hline martirizar & 1 & estado & & presidente & 1 & social & \\
\hline convulso & 1 & estado & & beneficiar & 1 & social & \\
\hline distraído & 1 & caráter & & descuidado & 1 & caráter & \\
\hline rápido & 1 & aparência & & desejoso & 1 & emo & \\
\hline diabólico & 1 & caráter & & maligno & 1 & caráter & \\
\hline atual & 1 & erro & & civil & 1 & social & \\
\hline escandaloso & 1 & caráter & & rapagão & 1 & aparência & \\
\hline namorado & 1 & emo & social & pachorrento & 1 & caráter & \\
\hline desmaiar & 1 & estado & & experimentado & 1 & caráter & \\
\hline transformar & 1 & estado & & dependente & 1 & estado & \\
\hline inabalável & 1 & caráter & & explorador & 1 & caráter & \\
\hline possível & 1 & erro & & ocioso & 1 & caráter & social \\
\hline educar & 1 & caráter & & esbofar & 1 & estado & \\
\hline indefectível & 1 & caráter & & endomingado & 1 & social & \\
\hline pasmado & 1 & emo & & complexo & 1 & caráter & \\
\hline invulnerável & 1 & caráter & & caçador & 1 & social & \\
\hline criador & 1 & aparência & & desperto & 1 & estado & \\
\hline dona & 1 & erro & & atlético & 1 & aparência & \\
\hline justo & 1 & caráter & & simétrico & 1 & caráter & \\
\hline bem-fazer & 1 & aparência & & pesaroso & 1 & emo & \\
\hline adormecer & 1 & erro & & temperado & 1 & erro & \\
\hline revoltado & 1 & emo & & musculoso & 1 & aparência & \\
\hline monstro & 1 & aparência & & petrificar & 1 & emo & \\
\hline verdade & 1 & caráter & & encarado & 1 & estado & \\
\hline caro & 1 & caráter & social & corado & 1 & aparência & emo \\
\hline causa & 1 & estado & & desumano & 1 & caráter & \\
\hline espirituoso & 1 & caráter & & míope & 1 & aparência & \\
\hline protagonista & 1 & social & & desenganado & 1 & emo & \\
\hline maravilhoso & 1 & aparência & & padrinho & 1 & social & \\
\hline celeste & 1 & social & & saquarema & 1 & erro & \\
\hline mártir & 1 & social & & guerreiro & 1 & social & \\
\hline desconhecido & 1 & social & & interessado & 1 & estado & \\
\hline alheio & 1 & estado & & patriota & 1 & social & \\
\hline dama & 1 & social & & estático & 1 & estado & \\
\hline enérgico & 1 & caráter & & intrépido & 1 & caráter & \\
\hline dito & 1 & erro & & protegido & 1 & estado & \\
\hline desejar & 1 & emo & & horror & 1 & erro & \\
\hline sonhar & 1 & erro & & vencedor & 1 & social & \\
\hline vagabundo & 1 & caráter & & irrefletido & 1 & caráter & \\
\hline vago & 1 & caráter & & trabalhoso & 1 & erro & \\
\hline fugitivo & 1 & estado & & pseudônimo & 1 & erro & \\
\hline silvestre & 1 & social & & territorial & 1 & social & \\
\hline rosa & 1 & aparência & & rural & 1 & social & \\
\hline destinar & 1 & erro & & inventivo & 1 & caráter & \\
\hline desabrochar & 1 & aparência & & indivíduo & 1 & erro & \\
\hline limpo & 1 & aparência & & lúcido & 1 & caráter & \\
\hline cheiroso & 1 & aparência & & avesso & 1 & erro & \\
\hline sentar & 1 & estado & & experiente & 1 & social & \\
\hline graça & 1 & aparência & & diplomata & 1 & social & \\
\hline envolver & 1 & erro & & lisonjeiro & 1 & caráter & \\
\hline criatura & 1 & erro & & filósofo & 1 & social & \\
\hline masculino & 1 & aparência & & especialista & 1 & social & \\
\hline incurável & 1 & estado & & habilidoso & 1 & caráter & social \\
\hline compassivo & 1 & caráter & & superficial & 1 & caráter & \\
\hline completo & 1 & caráter & & enfadonho & 1 & caráter & \\
\hline
\end{tabular}




\begin{tabular}{|c|c|c|c|c|c|c|}
\hline caminho & 1 & erro & & desajeitado & 1 & aparência \\
\hline leproso & 1 & aparência & & cordato & 1 & caráter \\
\hline revolucionário & 1 & caráter & & gago & 1 & aparência \\
\hline desdenhar & 1 & emo & & incompleto & 1 & emo \\
\hline único & 1 & erro & & instalado & 1 & estado \\
\hline absoluto & 1 & caráter & & distintíssimo & 1 & caráter \\
\hline sacerdote & 1 & social & & deslocado & 1 & social \\
\hline fundo & 1 & erro & & intrometido & 1 & caráter \\
\hline súbito & 1 & erro & & faminto & 1 & estado \\
\hline comprometido & 1 & emo & & ambicionar & 1 & caráter \\
\hline parisiense & 1 & social & & atroz & 1 & caráter \\
\hline sensual & 1 & emo & & suspeito & 1 & social \\
\hline doce & 1 & caráter & emo & crédulo & 1 & caráter \\
\hline cúmplice & 1 & caráter & & credor & 1 & social \\
\hline próprio & 1 & erro & & conhecido & 1 & social \\
\hline terrível & 1 & emo & & grego & 1 & social \\
\hline princesa & 1 & social & & gracioso & 1 & aparência \\
\hline brutal & 1 & caráter & & detestável & 1 & emo \\
\hline perverso & 1 & caráter & & burguês & 1 & social \\
\hline cínico & 1 & caráter & & nulo & 1 & caráter \\
\hline falso & 1 & caráter & & injusto & 1 & caráter \\
\hline esfarrapado & 1 & aparência & social & alado & 1 & aparência \\
\hline candeia & 1 & aparência & & enfronhado & 1 & aparência \\
\hline natural & 1 & erro & & glorioso & 1 & social \\
\hline tamanho & 1 & erro & & riquíssimo & 1 & social \\
\hline cor & 1 & aparência & & colérico & 1 & emo \\
\hline ligeiro & 1 & aparência & & correto & 1 & caráter \\
\hline modesto & 1 & emo & caráter & gema & 1 & erro \\
\hline obscuro & 1 & social & & conservador & 1 & caráter \\
\hline vida & 1 & erro & & lamentável & 1 & emo \\
\hline pasmo & 1 & emo & & encarregado & 1 & social \\
\hline irrequieto & 1 & caráter & & disciplinar & 1 & caráter \\
\hline aceitar & 1 & erro & & soberbo & 1 & emo \\
\hline diabo & 1 & caráter & & temível & 1 & emo \\
\hline exigente & 1 & caráter & & desvalido & 1 & social \\
\hline numeroso & 1 & erro & & desengraçado & 1 & caráter \\
\hline pretensioso & 1 & caráter & & casmurro & 1 & caráter \\
\hline querer & 1 & erro & & metediço & 1 & caráter \\
\hline incomparável & 1 & caráter & & benemérito & 1 & social \\
\hline sedutor & 1 & caráter & & carioca & 1 & social \\
\hline sentir & 1 & emo & & rigoroso & 1 & caráter \\
\hline fidalgo & 1 & social & & cambista & 1 & social \\
\hline efeito & 1 & erro & & falido & 1 & social \\
\hline indispensável & 1 & estado & & despachado & 1 & caráter \\
\hline famoso & 1 & social & & desgostoso & 1 & emo \\
\hline atenção & 1 & estado & & avelhantar & 1 & aparência \\
\hline adorar & 1 & emo & & taludo & 1 & aparência \\
\hline velhaco & 1 & caráter & & desconfiado & 1 & caráter \\
\hline expressivo & 1 & erro & & apático & 1 & aparência \\
\hline \multirow[t]{7}{*}{ original } & 1 & caráter & & independente & 1 & estado \\
\hline & & & & decisivo & 1 & estado \\
\hline & & & & agreste & 1 & social \\
\hline & & & & alerta & 1 & estado \\
\hline & & & & mouro & 1 & social \\
\hline & & & & anêmico & 1 & aparência \\
\hline & & & & fácil & 1 & caráter \\
\hline
\end{tabular}




\begin{tabular}{|c|c|c|c|}
\hline adepto & 1 & erro & \\
\hline de $=$ gravata $=$ lavada & 1 & erro & \\
\hline peregrino & 1 & social & \\
\hline aleijado & 1 & aparência & \\
\hline serviçal & 1 & social & \\
\hline respeitador & 1 & emo & \\
\hline esperançoso & 1 & caráter & emo \\
\hline portador & 1 & social & \\
\hline incansável & 1 & caráter & \\
\hline coletivo & 1 & erro & \\
\hline caridoso & 1 & caráter & \\
\hline à-toa & 1 & social & \\
\hline inflexível & 1 & caráter & \\
\hline excitado & 1 & emo & \\
\hline parvo & 1 & caráter & \\
\hline fátuo & 1 & caráter & \\
\hline sórdido & 1 & caráter & \\
\hline assustado & 1 & emo & \\
\hline advogado & 1 & social & \\
\hline apessoado & 1 & caráter & \\
\hline postiço & 1 & erro & \\
\hline $\mathrm{de}=$ espavento & 1 & social & \\
\hline urbano & 1 & caráter & \\
\hline impertinente & 1 & caráter & \\
\hline compungido & 1 & emo & \\
\hline indisposto & 1 & emo & \\
\hline conquistador & 1 & caráter & \\
\hline afogueado & 1 & emo & \\
\hline pertencente & 1 & estado & \\
\hline agradável & 1 & emo & \\
\hline sutil & 1 & caráter & \\
\hline azedo & 1 & caráter & emo \\
\hline esquivo & 1 & caráter & \\
\hline medroso & 1 & emo & \\
\hline nostálgico & 1 & emo & \\
\hline sôfrego & 1 & emo & \\
\hline porco & 1 & aparência & \\
\hline inquieto & 1 & emo & \\
\hline decrépito & 1 & aparência & \\
\hline bêbedo & 1 & estado & \\
\hline decidido & 1 & caráter & \\
\hline suado & 1 & aparência & \\
\hline tipógrafo & 1 & social & \\
\hline devedor & 1 & caráter & social \\
\hline judeu & 1 & social & \\
\hline chique & 1 & social & \\
\hline rouco & 1 & aparência & \\
\hline despido & 1 & aparência & \\
\hline exceção & 1 & erro & \\
\hline zeloso & 1 & caráter & \\
\hline diligente & 1 & caráter & \\
\hline empurrar & 1 & estado & \\
\hline arrogante & 1 & caráter & \\
\hline linfático & 1 & aparência & \\
\hline febril & 1 & aparência & \\
\hline fardado & 1 & aparência & \\
\hline francês & 1 & social & \\
\hline
\end{tabular}




\begin{tabular}{|c|c|c|}
\hline engomado & 1 & aparência \\
\hline mulato & 1 & aparência \\
\hline franzino & 1 & aparência \\
\hline vendedor & 1 & social \\
\hline mascate & 1 & social \\
\hline convencido & 1 & emo \\
\hline protetor & 1 & caráter \\
\hline menino & 1 & aparência \\
\hline tolo & 1 & caráter \\
\hline cuidadoso & 1 & caráter \\
\hline malicioso & 1 & caráter \\
\hline roxo & 1 & aparência \\
\hline magrinho & 1 & aparência \\
\hline fluminense & 1 & social \\
\hline condescendente & 1 & caráter \\
\hline incrédulo & 1 & emo \\
\hline liquidar & 1 & estado \\
\hline desembaraçado & 1 & caráter \\
\hline matreiro & 1 & caráter \\
\hline fazendeiro & 1 & social \\
\hline larva & 1 & erro \\
\hline gotejante & 1 & estado \\
\hline agitado & 1 & emo \\
\hline barato & 1 & caráter \\
\hline baixote & 1 & aparência \\
\hline grudar & 1 & estado \\
\hline proporção & 1 & erro \\
\hline pândego & 1 & caráter \\
\hline conhecimento & 1 & erro \\
\hline direto & 1 & caráter \\
\hline estrompar & 1 & estado \\
\hline estabelecer & 1 & erro \\
\hline patrão & 1 & social \\
\hline imoral & 1 & caráter \\
\hline comendador & 1 & social \\
\hline capitalista & 1 & social \\
\hline abominável & 1 & emo \\
\hline descoberto & 1 & estado \\
\hline coveiro & 1 & social \\
\hline perpétuo & 1 & caráter \\
\hline mudo & 1 & aparência \\
\hline noturno & 1 & erro \\
\hline errante & 1 & social \\
\hline
\end{tabular}




\section{Apêndice 5 - Predicadores com múltipla categorização}

\begin{tabular}{|c|c|c|c|}
\hline & predicador & & \\
\hline & amigo & caráter & social \\
\hline & apático & aparência & emo \\
\hline & ardente & aparência & emo \\
\hline & azedo & caráter & emo \\
\hline & brabinho & caráter & emo \\
\hline & cenobita & caráter & social \\
\hline & cismarento & caráter & emo \\
\hline & contrariado & caráter & emo \\
\hline & corado & aparência & emo \\
\hline & mole & caráter & aparência \\
\hline & cruel & caráter & emo \\
\hline & lânguido & caráter & aparência \\
\hline & $\mathrm{de}=$ cabelinho $=$ na $=$ venta & caráter & emo \\
\hline & cabeçudo & caráter & aparência \\
\hline & delicado & caráter & aparência \\
\hline & trêmulo & aparência & emo \\
\hline & desconfiado & caráter & emo \\
\hline & ocioso & caráter & social \\
\hline & desgraçado & caráter & emo \\
\hline & esfarrapado & social & aparência \\
\hline & devedor & caráter & social \\
\hline & varonil & caráter & aparência \\
\hline & doce & caráter & emo \\
\hline & virgem & social & aparência \\
\hline & ébrio & caráter & aparência \\
\hline & jeitoso & caráter & aparência \\
\hline & embriagante & caráter & aparência \\
\hline & caro & caráter & social \\
\hline & emérito & caráter & social \\
\hline & ardente & caráter & aparência \\
\hline & enfeitiçadora & caráter & aparência \\
\hline & enfezado & caráter & emo \\
\hline & esperançoso & caráter & emo \\
\hline & estelionatário & caráter & social \\
\hline & estudioso & caráter & social \\
\hline & faceiro & aparência & emo \\
\hline & fanado & caráter & aparência \\
\hline & grosseiro & caráter & emo \\
\hline & habilidoso & caráter & social \\
\hline & impaciente & caráter & emo \\
\hline & indiferente & caráter & emo \\
\hline & intolerável & caráter & emo \\
\hline & irresistível & caráter & aparência \\
\hline
\end{tabular}




\begin{tabular}{|c|c|}
\hline livre & caráter \\
\hline meigo & caráter \\
\hline menina & aparência \\
\hline modesto & caráter \\
\hline namorado & emo \\
\hline pacífico & caráter \\
\hline passional & caráter \\
\hline perdido & caráter \\
\hline rabujento & caráter \\
\hline rude & caráter \\
\hline ruim & caráter \\
\hline sensível & caráter \\
\hline sentimental & caráter \\
\hline terno & caráter \\
\hline trêmulo & aparência \\
\hline valente & caráter \\
\hline
\end{tabular}


Apêndice 6 - Expressão de busca por ações

\section{Voz Ativa}

\section{Feminino:}

[sema=". *Pessoa. *" \& gen="F" \& func="SUBJ>"] [pos="ADV. *" \& lema!="não|nunca"]* @[pos="V" \& lema!="ser|estar|haver" \& temcagr!="PASS|PCP"]|

[lema="ela" \& func="SUBJ>"] @[pos="V" \& lema!="ser|estar|haver" \& temcagr!="PASS|PCP"]|

[sema="parentesco" \& gen="F" \& func="SUBJ>"] [word="de|do|da"]* [sema="Pessoa"]* [pos="ADV." \& lema!="não|nunca"]* @[pos="V" \& lema!="ser|estar|haver" \& temcagr!="PASS"]|

[lema="mulher|moça|rapariga|menina|senhora" \& func="SUBJ>"] @[pos="V" \& lema!="ser|estar|haver" \& temcagr!="PASS"]|

\section{Masculino:}

[sema=". *Pessoa. *" \& gen="M" \& func="SUBJ>"] [pos="ADV. *" \& lema!="não|nunca"]* @[pos="V" \& lema!="ser|estar|haver" \& temcagr!="PASS|PCP"]|

[lema="ele" \& func="SUBJ>"] @[pos="V" \& lema!="ser|estar|haver" \& temcagr!="PASS|PCP"]|

[sema="parentesco" \& gen="M" \& func="SUBJ>"] [word="de|do|da"] [sema="Pessoa"]* [pos="ADV.*" \& lema!="não|nunca"]* @[pos="V" \& lema!="ser|estar|haver" \& temcagr!="PASS"]|

[lema="homem|moço|rapaz|menino|senhor" \& func="SUBJ>"] @[pos="V" \& lema!="ser|estar|haver" \& temcagr!="PASS"]| 


\section{Apêndice 7 - Resultado das buscas por ações}

\begin{tabular}{|c|c|c|c|c|}
\hline & femininos & qtd & masculino & qtd \\
\hline & ter & 537 & ter & 825 \\
\hline & ficar & 279 & fazer & 487 \\
\hline & fazer & 272 & ficar & 378 \\
\hline & querer & 197 & querer & 342 \\
\hline & dar & 178 & dar & 292 \\
\hline & dizer & 167 & entrar & 276 \\
\hline & entrar & 160 & sair & 272 \\
\hline & olhar & 156 & dizer & 243 \\
\hline & sorrir & 153 & ver & 241 \\
\hline & ir & 146 & ir & 226 \\
\hline & voltar & 139 & olhar & 211 \\
\hline & sentir & 138 & voltar & 200 \\
\hline & saber & 111 & vir & 197 \\
\hline & ouvir & 109 & sentir & 194 \\
\hline ๖ & sair & 107 & chegar & 192 \\
\hline ป & ver & 101 & saber & 184 \\
\hline$\infty$ & falar & 99 & falar & 184 \\
\hline 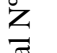 & vir & 98 & passar & 164 \\
\hline. & estremecer & 92 & sorrir & 160 \\
\hline ? & passar & 90 & tomar & 158 \\
\hline ש్లّ & responder & 89 & ouvir & 157 \\
\hline & aparecer & 86 & aparecer & 133 \\
\hline U & correr & 85 & responder & 124 \\
\hline$\stackrel{\vartheta}{\alpha}$ & morrer & 84 & continuar & 116 \\
\hline ن & amar & 74 & parar & 109 \\
\hline & chorar & 74 & deixar & 109 \\
\hline & levantar & 70 & correr & 108 \\
\hline & parecer & 68 & abrir & 108 \\
\hline & chegar & 68 & morrer & 106 \\
\hline & receber & 67 & estremecer & 100 \\
\hline & pensar & 66 & receber & 100 \\
\hline & gostar & 65 & pôr & 96 \\
\hline & trazer & 63 & conhecer & 96 \\
\hline & andar & 62 & procurar & 94 \\
\hline & viver & 62 & andar & 91 \\
\hline & continuar & 61 & viver & 91 \\
\hline & abrir & 59 & descer & 91 \\
\hline & tomar & 59 & ler & 84 \\
\hline & contar & 58 & achar & 83 \\
\hline & pedir & 55 & tirar & 82 \\
\hline & deixar & 55 & cair & 82 \\
\hline & cair & 54 & amar & 81 \\
\hline
\end{tabular}




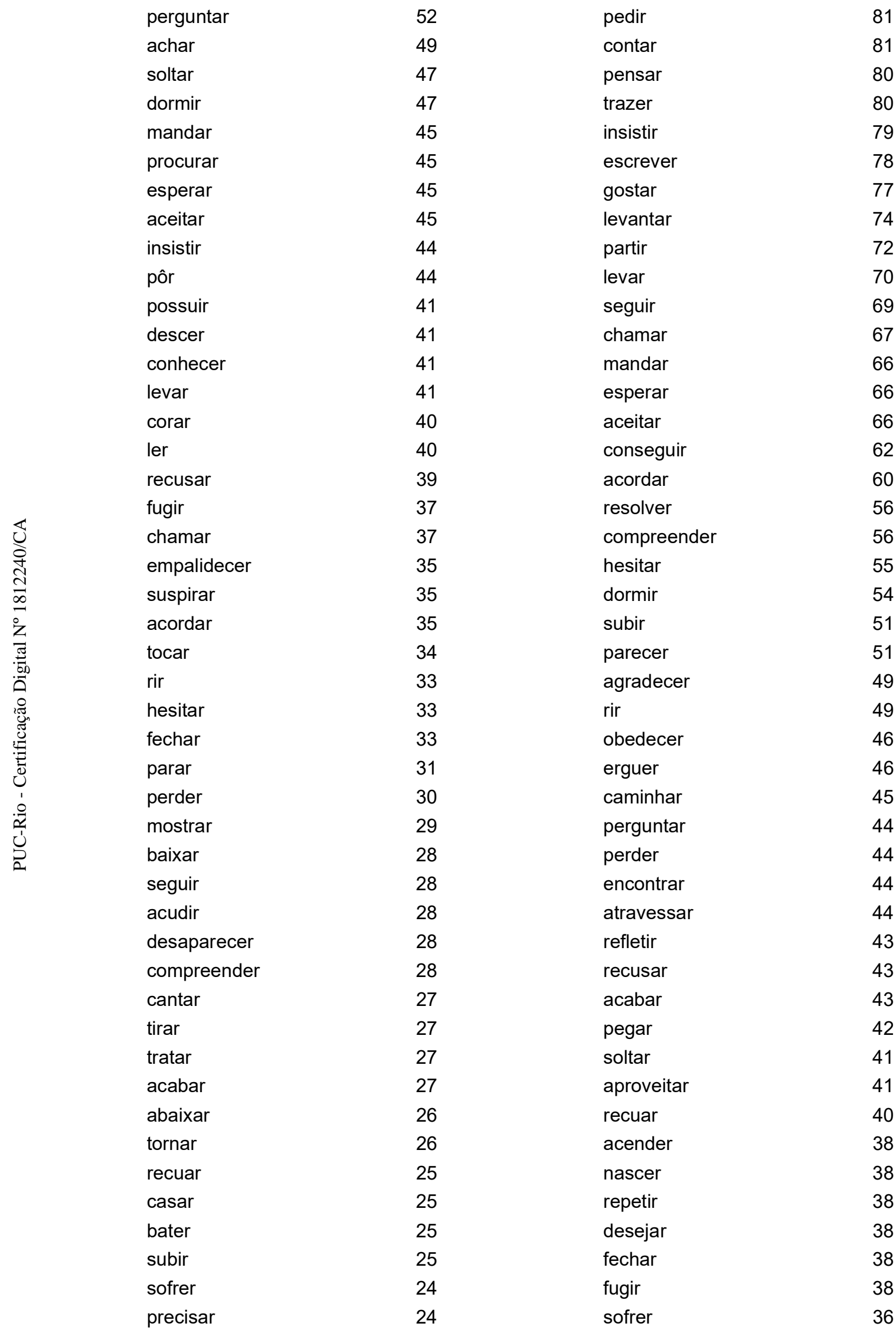




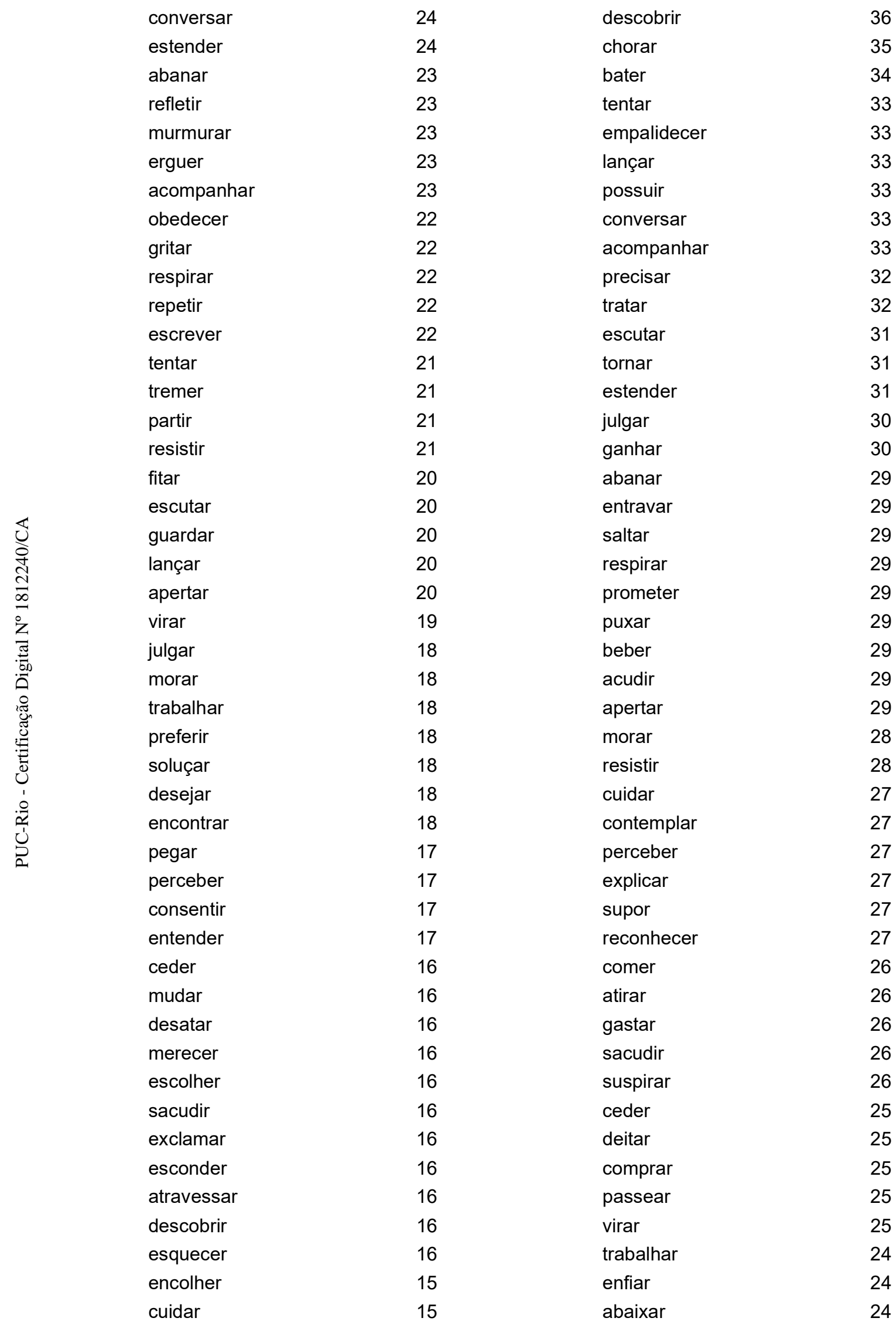




\begin{tabular}{|c|c|}
\hline adivinhar & 15 \\
\hline dançar & 15 \\
\hline ignorar & 15 \\
\hline proferir & 15 \\
\hline nascer & 15 \\
\hline reconhecer & 15 \\
\hline resolver & 15 \\
\hline adoecer & 14 \\
\hline caminhar & 14 \\
\hline notar & 14 \\
\hline prosseguir & 14 \\
\hline assistir & 14 \\
\hline padecer & 14 \\
\hline inclinar & 13 \\
\hline aprovar & 13 \\
\hline aprender & 13 \\
\hline contemplar & 13 \\
\hline saltar & 13 \\
\hline intervir & 13 \\
\hline usar & 13 \\
\hline passear & 13 \\
\hline acreditar & 13 \\
\hline exercer & 13 \\
\hline confessar & 13 \\
\hline romper & 12 \\
\hline concordar & 12 \\
\hline fingir & 12 \\
\hline deitar & 12 \\
\hline reparar & 12 \\
\hline entravar & 12 \\
\hline comer & 12 \\
\hline enxugar & 12 \\
\hline conservar & 12 \\
\hline atirar & 12 \\
\hline acrescentar & 12 \\
\hline servir & 12 \\
\hline referir & 11 \\
\hline teimar & 11 \\
\hline estacar & 11 \\
\hline supor & 11 \\
\hline prometer & 11 \\
\hline observar & 11 \\
\hline sonhar & 11 \\
\hline morder & 11 \\
\hline recear & 11 \\
\hline rezar & 11 \\
\hline
\end{tabular}

morder 24

mostrar 24

estacar 23

preferir 23

consentir 23

pagar 23

meter 23

buscar 23

guardar 23

pertencer 23

haver 23

apresentar 23

referir 22

gritar 22

concluir 22

cantar 22

desaparecer 22

começar 22

proferir 21

prosseguir 21

concordar 20

reparar 20

escolher 20

meditar 20

observar 20

exclamar 20

aprovar 19

romper 19

teimar 19

merecer 19

avançar 19

tremer 19

arranjar 19

declarar 19

dirigir 19

penetrar 19

examinar 18

embarcar 18

apanhar 18

entender 18

encher 18

jogar 18

adorar 18

atribuir $\quad 17$

gozar 17

cortar 17 


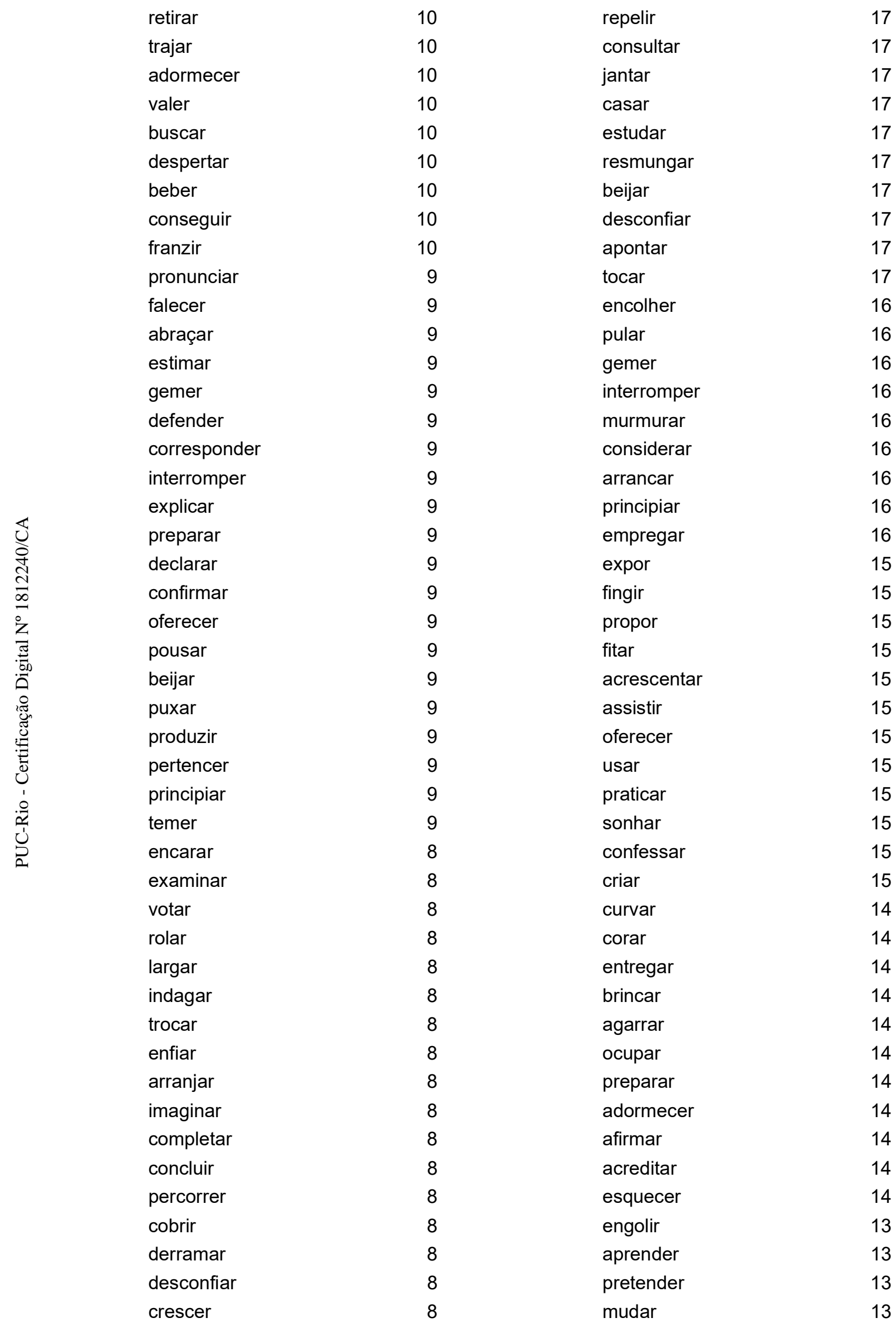




\begin{tabular}{|c|c|c|c|c|}
\hline & dever & 8 & lembrar & 13 \\
\hline & negar & 8 & freqüentar & 13 \\
\hline & criar & 8 & alcançar & 13 \\
\hline & volver & 8 & surgir & 13 \\
\hline & começar & 8 & recorrer & 12 \\
\hline & adorar & 8 & adquirir & 12 \\
\hline & relancear & 7 & vender & 12 \\
\hline & recorrer & 7 & largar & 12 \\
\hline & reclamar & 7 & enxugar & 12 \\
\hline & agradecer & 7 & matar & 12 \\
\hline & ajudar & 7 & indagar & 12 \\
\hline & existir & 7 & trocar & 12 \\
\hline & convidar & 7 & montar & 12 \\
\hline & saborear & 7 & abandonar & 12 \\
\hline & conter & 7 & experimentar & 12 \\
\hline & gastar & 7 & percorrer & 12 \\
\hline & pagar & 7 & valer & 12 \\
\hline & terminar & 7 & descansar & 12 \\
\hline ভ্ঠ & experimentar & 7 & exigir & 12 \\
\hline$\stackrel{\text { I }}{\stackrel{2}{4}}$ & conceber & 7 & protestar & 12 \\
\hline$\frac{1}{\infty}$ & exigir & 7 & franzir & 12 \\
\hline $\bar{z}$ & protestar & 7 & aplaudir & 11 \\
\hline 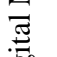 & disfarçar & 7 & encarar & 11 \\
\hline .5 & vestir & 7 & recordar & 11 \\
\hline ঞ્ఝ్ & haver & 7 & ignorar & 11 \\
\hline$\stackrel{\mathscr{C}}{=}$ & dispor & 7 & arder & 11 \\
\hline$=$ & apresentar & 7 & cravar & 11 \\
\hline$\vdots$ & aproveitar & 7 & desviar & 11 \\
\hline 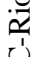 & coser & 6 & assomar & 11 \\
\hline ن & comparar & 6 & notar & 11 \\
\hline & colocar & 6 & suportar & 11 \\
\hline & indicar & 6 & fumar & 11 \\
\hline & atender & 6 & reunir & 11 \\
\hline & dobrar & 6 & obter & 11 \\
\hline & propor & 6 & torcer & 11 \\
\hline & reaparecer & 6 & terminar & 11 \\
\hline & ralhar & 6 & cruzar & 11 \\
\hline & brincar & 6 & servir & 11 \\
\hline & meditar & 6 & cumprir & 11 \\
\hline & ocupar & 6 & confiar & 11 \\
\hline & escapar & 6 & dever & 11 \\
\hline & menear & 6 & arrastar & 11 \\
\hline & interrogar & 6 & conduzir & 11 \\
\hline & jurar & 6 & acenar & 10 \\
\hline & assentar & 6 & adivinhar & 10 \\
\hline & lavar & 6 & dobrar & 10 \\
\hline
\end{tabular}




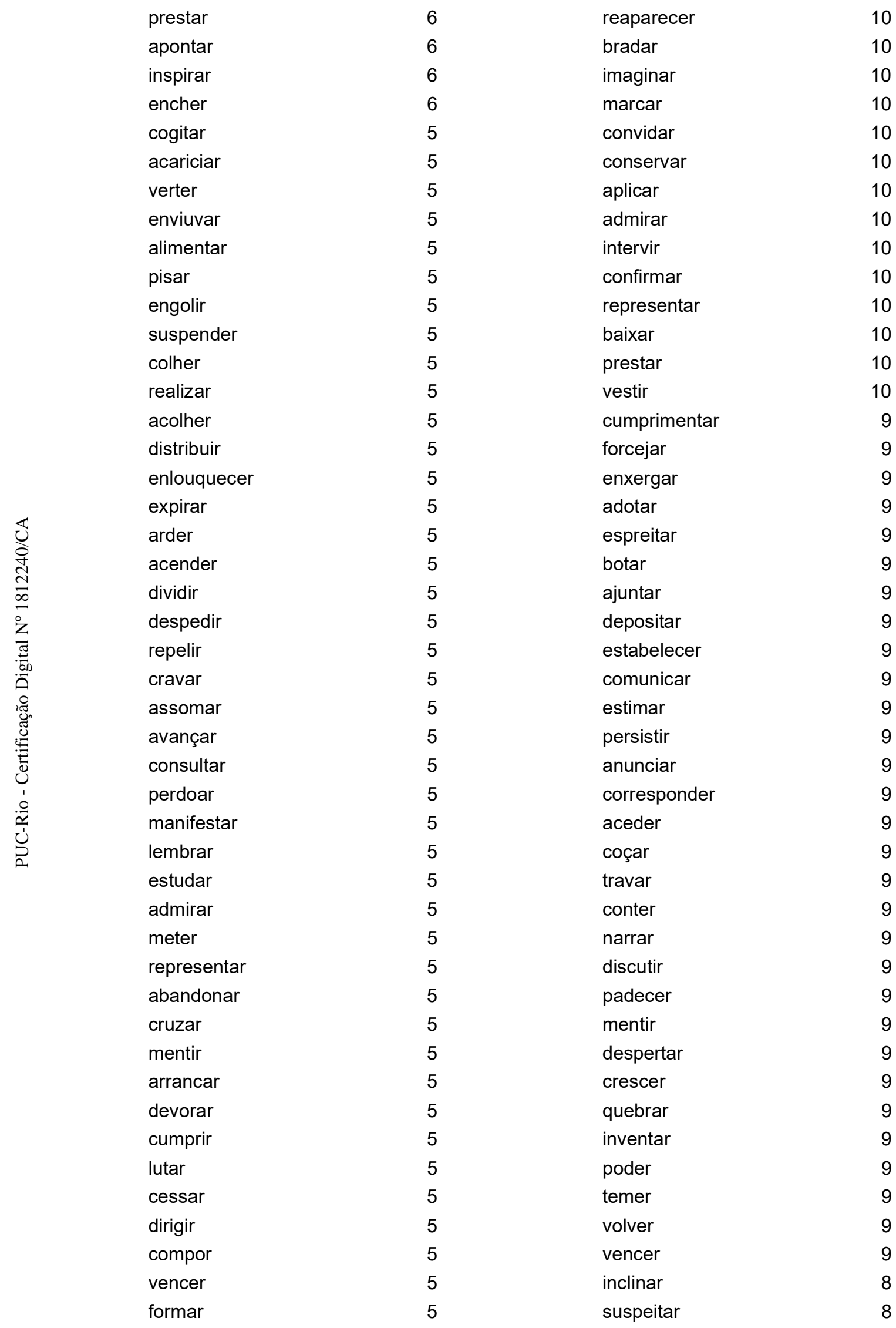




\begin{tabular}{|c|c|c|c|c|}
\hline & aludir & 4 & piscar & 8 \\
\hline & exultar & 4 & pisar & 8 \\
\hline & recobrar & 4 & mergulhar & 8 \\
\hline & valsar & 4 & votar & 8 \\
\hline & ostentar & 4 & dançar & 8 \\
\hline & tecer & 4 & transpor & 8 \\
\hline & reler & 4 & abraçar & 8 \\
\hline & executar & 4 & desatar & 8 \\
\hline & ressonar & 4 & sacrificar & 8 \\
\hline & enrolar & 4 & desistir & 8 \\
\hline & enrubescer & 4 & existir & 8 \\
\hline & adquirir & 4 & construir & 8 \\
\hline & botar & 4 & jurar & 8 \\
\hline & segurar & 4 & negar & 8 \\
\hline & estranhar & 4 & roubar & 8 \\
\hline & amanhecer & 4 & dispor & 8 \\
\hline & apanhar & 4 & governar & 8 \\
\hline & vibrar & 4 & triunfar & 7 \\
\hline & cochichar & 4 & concertar & 7 \\
\hline $\mathrm{V}$ & agonizar & 4 & ousar & 7 \\
\hline 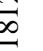 & gozar & 4 & adoecer & 7 \\
\hline Z & invejar & 4 & discorrer & 7 \\
\hline$=$ & recordar & 4 & pronunciar & 7 \\
\hline 5 & amamentar & 4 & investir & 7 \\
\hline & vacilar & 4 & suar & 7 \\
\hline 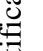 & pretender & 4 & exprimir & 7 \\
\hline 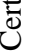 & mover & 4 & visitar & 7 \\
\hline & rasgar & 4 & suspender & 7 \\
\hline $\bar{\alpha}$ & persistir & 4 & almoçar & 7 \\
\hline & permanecer & 4 & trepar & 7 \\
\hline & desprezar & 4 & segurar & 7 \\
\hline & arquejar & 4 & retirar & 7 \\
\hline & desviar & 4 & fixar & 7 \\
\hline & cantarolar & 4 & falecer & 7 \\
\hline & limpar & 4 & indicar & 7 \\
\hline & retorquir & 4 & expirar & 7 \\
\hline & comprar & 4 & permanecer & 7 \\
\hline & jantar & 4 & impor & 7 \\
\hline & evitar & 4 & apressar & 7 \\
\hline & entregar & 4 & defender & 7 \\
\hline & aceder & 4 & combater & 7 \\
\hline & afastar & 4 & afagar & 7 \\
\hline & avistar & 4 & replicar & 7 \\
\hline & cheirar & 4 & plantar & 7 \\
\hline & desenvolver & 4 & resumir & 7 \\
\hline & arredar & 4 & sentar & 7 \\
\hline
\end{tabular}




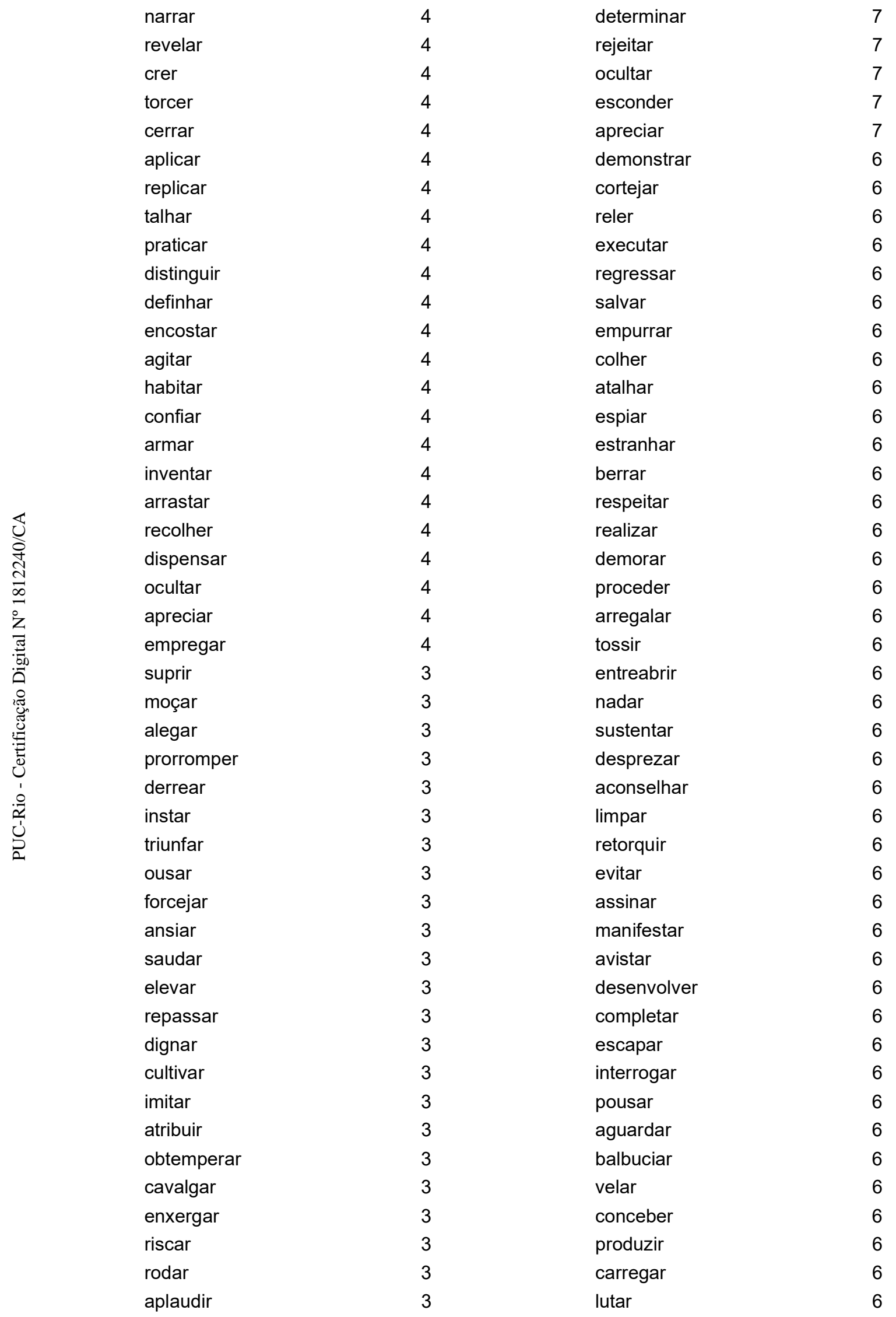




\begin{tabular}{|c|c|c|c|c|}
\hline & adotar & 3 & depor & 6 \\
\hline & pular & 3 & ordenar & 6 \\
\hline & nutrir & 3 & manter & 6 \\
\hline & renunciar & 3 & rezar & 6 \\
\hline & chupar & 3 & galgar & 6 \\
\hline & exprimir & 3 & bastar & 6 \\
\hline & ajuntar & 3 & abusar & 6 \\
\hline & mergulhar & 3 & faltar & 6 \\
\hline & recomendar & 3 & campear & 5 \\
\hline & almoçar & 3 & recompor & 5 \\
\hline & disparar & 3 & delinear & 5 \\
\hline & trepar & 3 & comandar & 5 \\
\hline & espalhar & 3 & recobrar & 5 \\
\hline & tapar & 3 & brandir & 5 \\
\hline & embarcar & 3 & aventurar & 5 \\
\hline & detestar & 3 & cultivar & 5 \\
\hline & comunicar & 3 & aspirar & 5 \\
\hline & conquistar & 3 & espalmar & 5 \\
\hline & curvar & 3 & encomendar & 5 \\
\hline$V$ & demorar & 3 & atentar & 5 \\
\hline 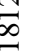 & proceder & 3 & caçar & 5 \\
\hline 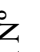 & dissimular & 3 & simpatizar & 5 \\
\hline$\pi$ & arregalar & 3 & entreter & 5 \\
\hline & reproduzir & 3 & comparecer & 5 \\
\hline & cortar & 3 & desafiar & 5 \\
\hline 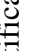 & sussurrar & 3 & recitar & 5 \\
\hline & animar & 3 & emprestar & 5 \\
\hline & repousar & 3 & fundar & 5 \\
\hline 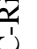 & apressar & 3 & amanhecer & 5 \\
\hline & matar & 3 & sacar & 5 \\
\hline & sacrificar & 3 & trajar & 5 \\
\hline & prever & 3 & detestar & 5 \\
\hline & jazer & 3 & acolher & 5 \\
\hline & assinar & 3 & acentuar & 5 \\
\hline & enfeitar & 3 & distribuir & 5 \\
\hline & voar & 3 & soprar & 5 \\
\hline & odiar & 3 & reclamar & 5 \\
\hline & agarrar & 3 & curar & 5 \\
\hline & ajoelhar & 3 & desesperar & 5 \\
\hline & reunir & 3 & roncar & 5 \\
\hline & bradar & 3 & endireitar & 5 \\
\hline & segredar & 3 & rasgar & 5 \\
\hline & desmaiar & 3 & ajudar & 5 \\
\hline & resmungar & 3 & calcular & 5 \\
\hline & afirmar & 3 & repousar & 5 \\
\hline & afagar & 3 & assumir & 5 \\
\hline
\end{tabular}




\begin{tabular}{|c|c|c|c|c|}
\hline & afetar & 3 & calçar & 5 \\
\hline & pender & 3 & surpreender & 5 \\
\hline & arfar & 3 & odiar & 5 \\
\hline & balbuciar & 3 & sucumbir & 5 \\
\hline & descansar & 3 & afastar & 5 \\
\hline & reprovar & 3 & soluçar & 5 \\
\hline & resumir & 3 & ajoelhar & 5 \\
\hline & alcançar & 3 & bocejar & 5 \\
\hline & quebrar & 3 & exagerar & 5 \\
\hline & carregar & 3 & aproximar & 5 \\
\hline & despir & 3 & cerrar & 5 \\
\hline & ganhar & 3 & afetar & 5 \\
\hline & reprimir & 3 & distinguir & 5 \\
\hline & empenhar & 3 & assentar & 5 \\
\hline & cometer & 3 & recear & 5 \\
\hline & ordenar & 3 & cometer & 5 \\
\hline & manter & 3 & recolher & 5 \\
\hline & forçar & 3 & dispensar & 5 \\
\hline & penetrar & 3 & compor & 5 \\
\hline$V$ & conduzir & 3 & substituir & 5 \\
\hline 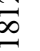 & esfregar & 3 & retificar & 4 \\
\hline 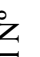 & atacar & 3 & divergir & 4 \\
\hline$\Xi$ & jogar & 3 & aludir & 4 \\
\hline & proteger & 3 & irromper & 4 \\
\hline E. & surgir & 3 & carecer & 4 \\
\hline & aquiescer & 2 & manejar & 4 \\
\hline & compartir & 2 & valsar & 4 \\
\hline & abocanhar & 2 & lastimar & 4 \\
\hline & rabear & 2 & opinar & 4 \\
\hline & almejar & 2 & amarar & 4 \\
\hline & acorrer & 2 & derrubar & 4 \\
\hline & enlaçar & 2 & pasmar & 4 \\
\hline & titubear & 2 & engordar & 4 \\
\hline & sarar & 2 & melhorar & 4 \\
\hline & acenar & 2 & engendrar & 4 \\
\hline & assegurar & 2 & desembarcar & 4 \\
\hline & gerar & 2 & combinar & 4 \\
\hline & folhear & 2 & participar & 4 \\
\hline & simular & 2 & cochilar & 4 \\
\hline & opinar & 2 & rugir & 4 \\
\hline & cumprimentar & 2 & afrouxar & 4 \\
\hline & amarar & 2 & nutrir & 4 \\
\hline & decorar & 2 & chupar & 4 \\
\hline & delirar & 2 & cavar & 4 \\
\hline & contrair & 2 & brigar & 4 \\
\hline & acatar & 2 & mirar & 4 \\
\hline
\end{tabular}




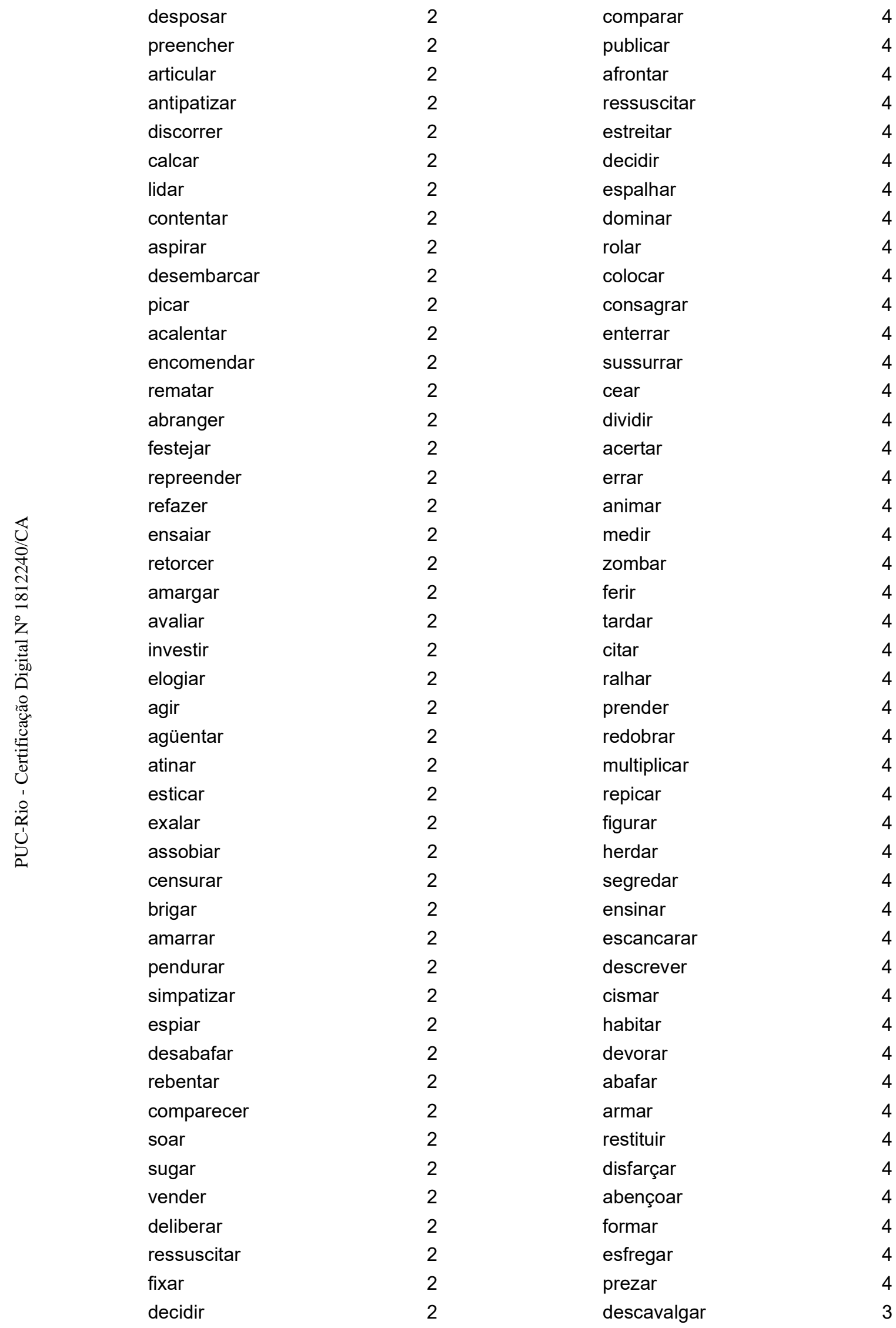




\begin{tabular}{|c|c|c|c|c|}
\hline & sossegar & 2 & simbolizar & 3 \\
\hline & insinuar & 2 & tanger & 3 \\
\hline & ingerir & 2 & secundar & 3 \\
\hline & esvaziar & 2 & relancear & 3 \\
\hline & regar & 2 & alegar & 3 \\
\hline & tender & 2 & entrever & 3 \\
\hline & brilhar & 2 & renovar & 3 \\
\hline & consolar & 2 & exultar & 3 \\
\hline & recomeçar & 2 & remar & 3 \\
\hline & dominar & 2 & esboçar & 3 \\
\hline & rondar & 2 & caçoar & 3 \\
\hline & pressentir & 2 & folhear & 3 \\
\hline & interceder & 2 & contestar & 3 \\
\hline & expor & 2 & exaltar & 3 \\
\hline & desfiar & 2 & rufar & 3 \\
\hline & varrer & 2 & acariciar & 3 \\
\hline & durar & 2 & alçar & 3 \\
\hline & arrumar & 2 & gracejar & 3 \\
\hline ญ & enterrar & 2 & tecer & 3 \\
\hline 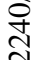 & transpor & 2 & revirar & 3 \\
\hline$\infty$ & cansar & 2 & descender & 3 \\
\hline $\bar{z}$ & queimar & 2 & contrair & 3 \\
\hline 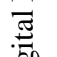 & raspar & 2 & influir & 3 \\
\hline .50 & calcular & 2 & apear & 3 \\
\hline : & errar & 2 & ambicionar & 3 \\
\hline$\stackrel{\overparen{:}}{=}$ & nadar & 2 & encetar & 3 \\
\hline 胥 & concentrar & 2 & calcar & 3 \\
\hline ! & sustentar & 2 & providenciar & 3 \\
\hline 党 & farejar & 2 & residir & 3 \\
\hline 2 & pesar & 2 & imitar & 3 \\
\hline & calçar & 2 & desenrolar & 3 \\
\hline & duvidar & 2 & adiar & 3 \\
\hline & informar & 2 & escalar & 3 \\
\hline & amassar & 2 & aparar & 3 \\
\hline & desculpar & 2 & reatar & 3 \\
\hline & suportar & 2 & riscar & 3 \\
\hline & anunciar & 2 & assestar & 3 \\
\hline & prender & 2 & rodear & 3 \\
\hline & seduzir & 2 & mascar & 3 \\
\hline & redobrar & 2 & catar & 3 \\
\hline & obrigar & 2 & atinar & 3 \\
\hline & envelhecer & 2 & explodir & 3 \\
\hline & encerrar & 2 & mastigar & 3 \\
\hline & sufocar & 2 & esticar & 3 \\
\hline & resplandecer & 2 & fiar & 3 \\
\hline & escorrer & 2 & firmar & 3 \\
\hline
\end{tabular}




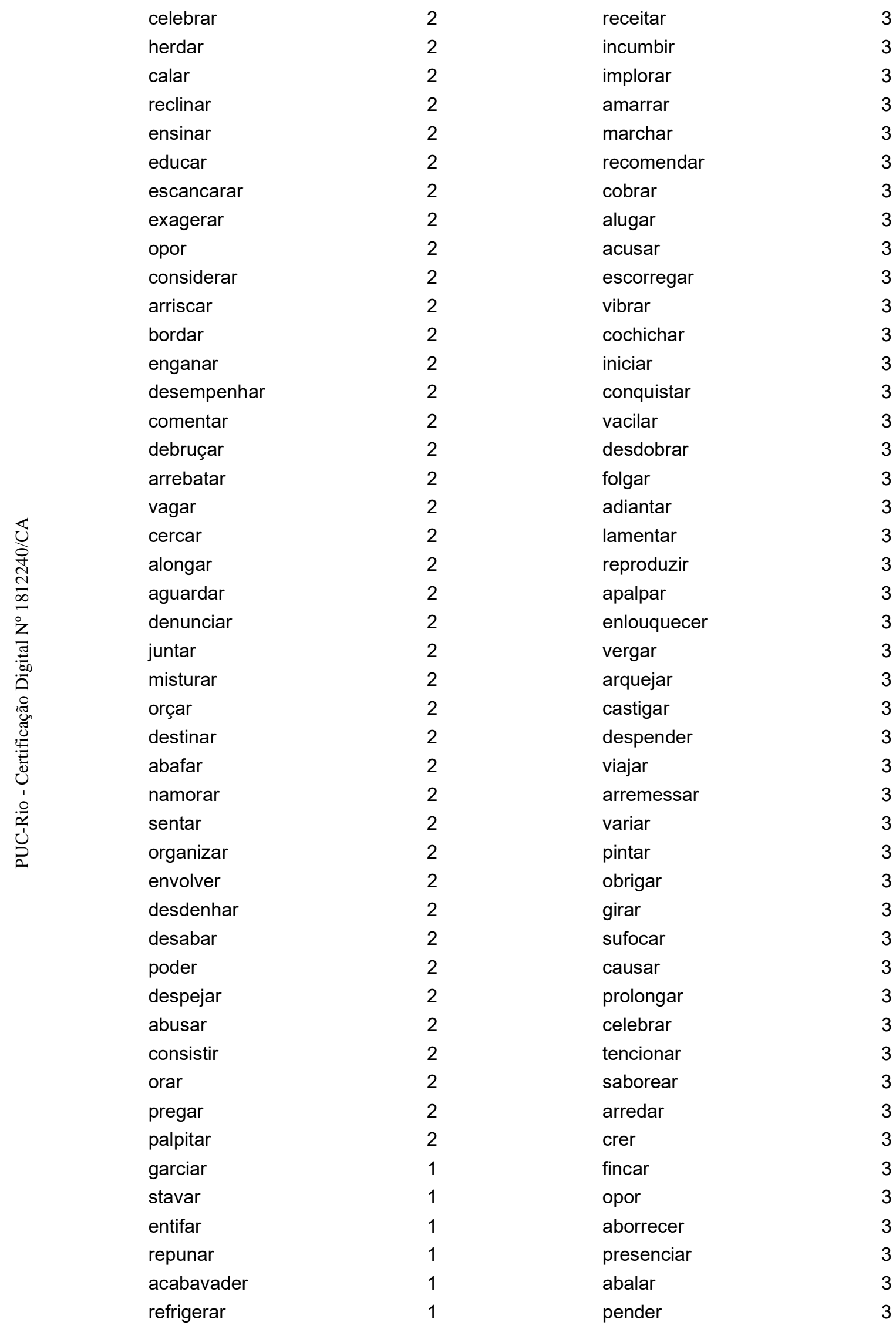




\begin{tabular}{|c|c|c|c|c|}
\hline & empulhar & 1 & cercar & 3 \\
\hline & confeccionar & 1 & alongar & 3 \\
\hline & bochechar & 1 & cobrir & 3 \\
\hline & respondeulher & 1 & lavar & 3 \\
\hline & haurir & 1 & encostar & 3 \\
\hline & desamar & 1 & agitar & 3 \\
\hline & fuchicar & 1 & derramar & 3 \\
\hline & predizer & 1 & encarregar & 3 \\
\hline & comletar & 1 & inspirar & 3 \\
\hline & inalar & 1 & sangrar & 3 \\
\hline & personificar & 1 & exercer & 3 \\
\hline & tergiversar & 1 & condenar & 3 \\
\hline & polcar & 1 & permitir & 3 \\
\hline & desamarrar & 1 & sorver & 3 \\
\hline & superintender & 1 & atacar & 3 \\
\hline & treplicar & 1 & descobriar & 2 \\
\hline & sobrestar & 1 & assuntar & 2 \\
\hline & liberalizar & 1 & referendar & 2 \\
\hline & ratificar & 1 & filosofar & 2 \\
\hline & afincar & 1 & superintender & 2 \\
\hline & estribar & 1 & sobrestar & 2 \\
\hline ¿ & campear & 1 & designar & 2 \\
\hline$\pi$ & canonizar & 1 & integrar & 2 \\
\hline & recriminar & 1 & negacear & 2 \\
\hline : & reassumir & 1 & abordar & 2 \\
\hline & confiscar & 1 & enveredar & 2 \\
\hline 这 & sestear & 1 & abocanhar & 2 \\
\hline 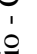 & espiralar & 1 & refutar & 2 \\
\hline $\bar{E}$ & cardar & 1 & perdurar & 2 \\
\hline & batalhar & 1 & aprumar & 2 \\
\hline & apelidar & 1 & endereçar & 2 \\
\hline & conspurcar & 1 & capinar & 2 \\
\hline & esparzir & 1 & troar & 2 \\
\hline & dissecar & 1 & aderir & 2 \\
\hline & engrolar & 1 & recalcar & 2 \\
\hline & remoer & 1 & professar & 2 \\
\hline & costurar & 1 & esporear & 2 \\
\hline & ascender & 1 & testemunhar & 2 \\
\hline & recompor & 1 & fastar & 2 \\
\hline & esfolhar & 1 & intentar & 2 \\
\hline & perdurar & 1 & embarafustar & 2 \\
\hline & rebater & 1 & prorromper & 2 \\
\hline & colear & 1 & cocar & 2 \\
\hline & reconstituir & 1 & imperar & 2 \\
\hline & injuriar & 1 & analisar & 2 \\
\hline & perverter & 1 & interpretar & 2 \\
\hline
\end{tabular}




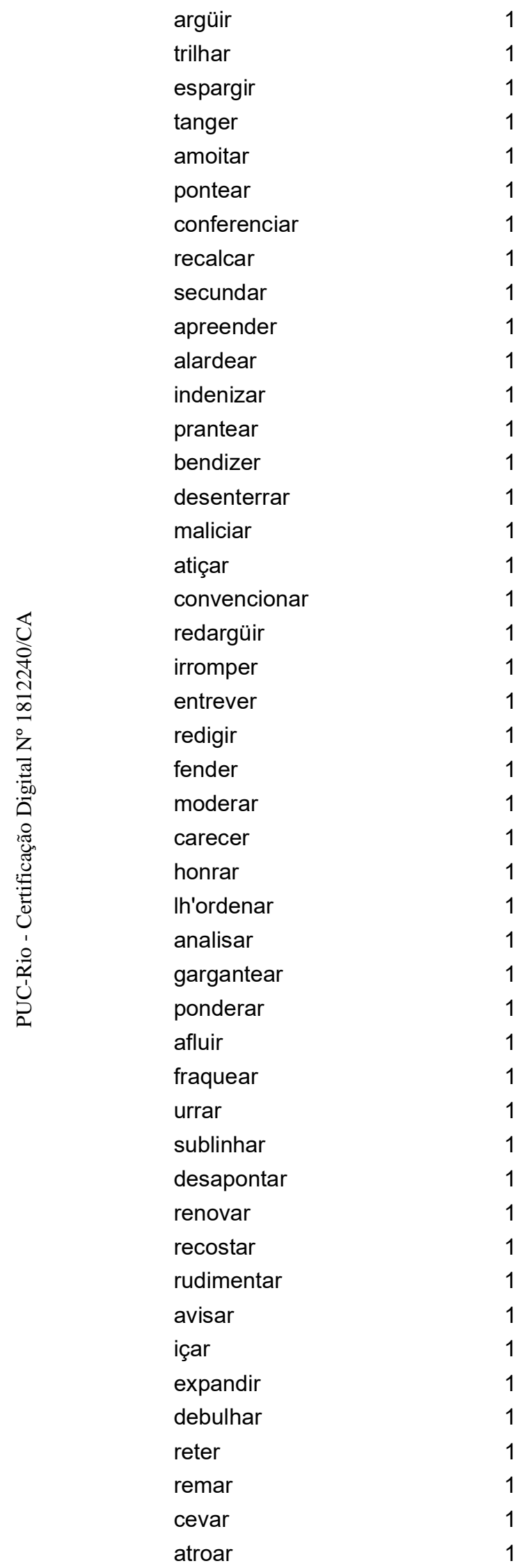

avisar 2

amuar 2

agachar 2

flechar 2

olvidar 2

sarar 2

reter 2

partilhar 2

desonrar 2

semelhar 2

revolver 2

balançar 2

trovejar 2

ruminar 2

assegurar 2

gargalhar 2

embrulhar 2

gerar 2

discordar 2

advogar 2

exercitar 2

vigiar 2

requerer 2

inchar 2

rememorar 2

irradiar 2

rimar 2

raciocinar 2

incubar 2

coxear 2

antever 2

endoidecer 2

lograr 2

obrar 2

desmanchar 2

relatar 2

desenhar 2

emendar 2

enviuvar 2

derrotar 2

tropeçar 2

somar 2

lidar 2

retribuir 2

semear 2

pretextar 2 


\begin{tabular}{|c|c|c|c|c|}
\hline & divinizar & 1 & imprimir & 2 \\
\hline & semelhar & 1 & idear & 2 \\
\hline & brandir & 1 & cursar & 2 \\
\hline & encobrir & 1 & gabar & 2 \\
\hline & esboçar & 1 & mamar & 2 \\
\hline & aureolar & 1 & matutar & 2 \\
\hline & fortalecer & 1 & esbarrar & 2 \\
\hline & trovejar & 1 & rematar & 2 \\
\hline & ruminar & 1 & alargar & 2 \\
\hline & invectivar & 1 & impelir & 2 \\
\hline & beijocar & 1 & topar & 2 \\
\hline & sofrear & 1 & espichar & 2 \\
\hline & instituir & 1 & advertir & 2 \\
\hline & perpetrar & 1 & relembrar & 2 \\
\hline & resultar & 1 & ensaiar & 2 \\
\hline & gargalhar & 1 & esgotar & 2 \\
\hline & contratar & 1 & agasalhar & 2 \\
\hline & dissertar & 1 & apartar & 2 \\
\hline & horrorizar & 1 & bufar & 2 \\
\hline$V$ & tranqüilizar & 1 & avaliar & 2 \\
\hline 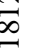 & primar & 1 & tombar & 2 \\
\hline 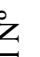 & descascar & 1 & coser & 2 \\
\hline$\Xi$ & formular & 1 & deparar & 2 \\
\hline & despeitar & 1 & elogiar & 2 \\
\hline & amortalhar & 1 & oficiar & 2 \\
\hline 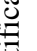 & conchegar & 1 & expedir & 2 \\
\hline 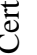 & exercitar & 1 & afundar & 2 \\
\hline 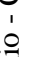 & beneficiar & 1 & estourar & 2 \\
\hline & retocar & 1 & insultar & 2 \\
\hline & escurecer & 1 & ditar & 2 \\
\hline & concertar & 1 & resfolegar & 2 \\
\hline & desvendar & 1 & espernear & 2 \\
\hline & inaugurar & 1 & descair & 2 \\
\hline & cortejar & 1 & avultar & 2 \\
\hline & aferir & 1 & assobiar & 2 \\
\hline & emoldurar & 1 & circular & 2 \\
\hline & envenenar & 1 & desabotoar & 2 \\
\hline & irradiar & 1 & guiar & 2 \\
\hline & espedaçar & 1 & estragar & 2 \\
\hline & manchar & 1 & costumar & 2 \\
\hline & surrar & 1 & desabafar & 2 \\
\hline & suspeitar & 1 & solicitar & 2 \\
\hline & rescender & 1 & mexer & 2 \\
\hline & rever & 1 & liquidar & 2 \\
\hline & retesar & 1 & rebentar & 2 \\
\hline & aliviar & 1 & aumentar & 2 \\
\hline
\end{tabular}




\begin{tabular}{|c|c|c|c|c|}
\hline & raciocinar & 1 & ranger & 2 \\
\hline & intercalar & 1 & consertar & 2 \\
\hline & derrubar & 1 & disparar & 2 \\
\hline & expelir & 1 & desprender & 2 \\
\hline & emperrar & 1 & maldizer & 2 \\
\hline & alisar & 1 & destruir & 2 \\
\hline & forjar & 1 & furtar & 2 \\
\hline & sobrevir & 1 & desmentir & 2 \\
\hline & transigir & 1 & sossegar & 2 \\
\hline & mercadejar & 1 & insinuar & 2 \\
\hline & arrepiar & 1 & vagabundear & 2 \\
\hline & serenar & 1 & esvaziar & 2 \\
\hline & recair & 1 & brilhar & 2 \\
\hline & atraiçoar & 1 & consolar & 2 \\
\hline & ajuizar & 1 & favorecer & 2 \\
\hline & descerrar & 1 & precipitar & 2 \\
\hline & decretar & 1 & recomeçar & 2 \\
\hline & execrar & 1 & invejar & 2 \\
\hline ঠ் & perscrutar & 1 & rondar & 2 \\
\hline 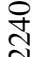 & dandar & 1 & varar & 2 \\
\hline$\infty$ & antever & 1 & invadir & 2 \\
\hline $\bar{z}$ & resumbrar & 1 & pressentir & 2 \\
\hline. & influir & 1 & repor & 2 \\
\hline .50 & copiar & 1 & caiar & 2 \\
\hline జ్ల్రి & pasmar & 1 & recuperar & 2 \\
\hline$\stackrel{\mathscr{:}}{=}$ & macular & 1 & custar & 2 \\
\hline 焉 & encaminhar & 1 & varrer & 2 \\
\hline $\begin{array}{l}1 \\
\vdots\end{array}$ & lograr & 1 & desandar & 2 \\
\hline $\bar{\alpha}$ & obrar & 1 & durar & 2 \\
\hline 3 & apelar & 1 & contribuir & 2 \\
\hline & enjoar & 1 & amaldiçoar & 2 \\
\hline & caluniar & 1 & gesticular & 2 \\
\hline & premeditar & 1 & mover & 2 \\
\hline & desenhar & 1 & queimar & 2 \\
\hline & engordar & 1 & arregaçar & 2 \\
\hline & presidir & 1 & entoar & 2 \\
\hline & ambicionar & 1 & atrair & 2 \\
\hline & funcionar & 1 & despedir & 2 \\
\hline & recalcitrar & 1 & concentrar & 2 \\
\hline & emendar & 1 & ruir & 2 \\
\hline & estancar & 1 & surdir & 2 \\
\hline & exceder & 1 & assustar & 2 \\
\hline & depenar & 1 & cuspir & 2 \\
\hline & escovar & 1 & atender & 2 \\
\hline & reger & 1 & magoar & 2 \\
\hline & encetar & 1 & despachar & 2 \\
\hline
\end{tabular}




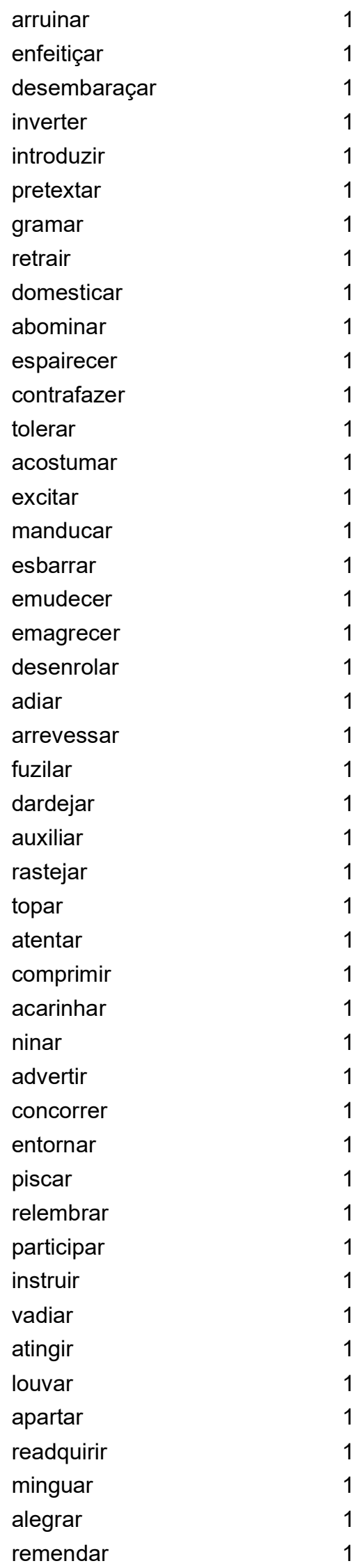

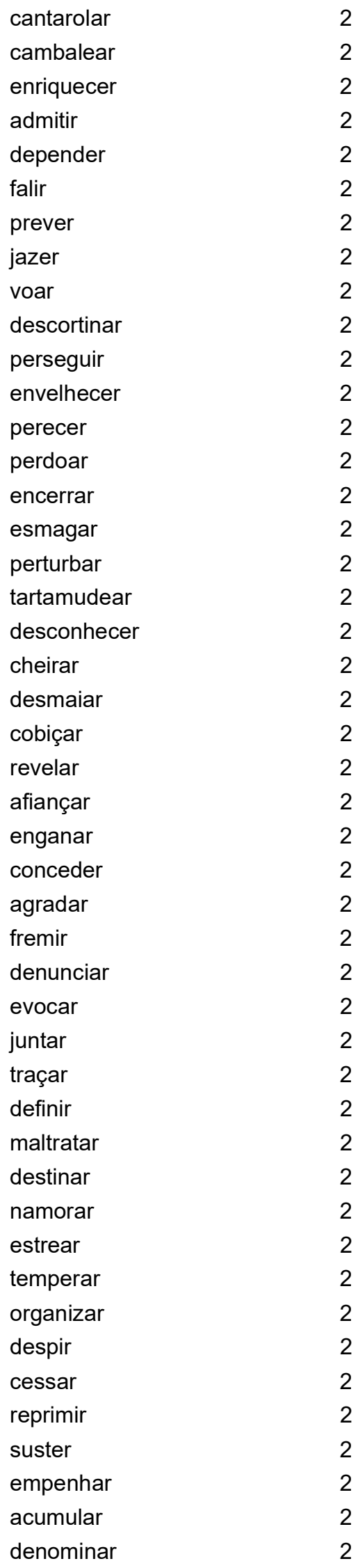




\begin{tabular}{|c|c|c|c|c|}
\hline & fabricar & 1 & fulminar & 2 \\
\hline & rugir & 1 & furar & 2 \\
\hline & tombar & 1 & ameaçar & 2 \\
\hline & atar & 1 & divertir & 2 \\
\hline & amontoar & 1 & forçar & 2 \\
\hline & acocorar & 1 & pregar & 2 \\
\hline & reviver & 1 & atarefadissimar & 1 \\
\hline & imprecar & 1 & solver & 1 \\
\hline & soerguer & 1 & rifir & 1 \\
\hline & beliscar & 1 & oxidar & 1 \\
\hline & postar & 1 & caricaturar & 1 \\
\hline & apurar & 1 & rouler & 1 \\
\hline & afrouxar & 1 & gavionar & 1 \\
\hline & tragar & 1 & pongar & 1 \\
\hline & catar & 1 & esborrifar & 1 \\
\hline & caçar & 1 & enquizlar & 1 \\
\hline & espumar & 1 & amontar & 1 \\
\hline & arremeter & 1 & avoar & 1 \\
\hline & inutilizar & 1 & noster & 1 \\
\hline$V$ & suar & 1 & desconversar & 1 \\
\hline 7 & ensopar & 1 & fairer & 1 \\
\hline Z & explodir & 1 & destrancar & 1 \\
\hline$=$ & afundar & 1 & desempacar & 1 \\
\hline 5 & bambolear & 1 & con-tinuar & 1 \\
\hline & espreitar & 1 & aposentar & 1 \\
\hline 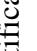 & mastigar & 1 & chicanar & 1 \\
\hline 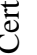 & facilitar & 1 & cotejar & 1 \\
\hline ó & ecoar & 1 & custear & 1 \\
\hline & roçar & 1 & haurir & 1 \\
\hline & arremedar & 1 & regatear & 1 \\
\hline & ditar & 1 & desamar & 1 \\
\hline & declinar & 1 & replantar & 1 \\
\hline & dedilhar & 1 & patear & 1 \\
\hline & descair & 1 & enguliar & 1 \\
\hline & ajeitar & 1 & acoroçar & 1 \\
\hline & emparelhar & 1 & poetar & 1 \\
\hline & atracar & 1 & corcovar & 1 \\
\hline & atrapalhar & 1 & embraçar & 1 \\
\hline & ensaboar & 1 & arrojouser & 1 \\
\hline & contrariar & 1 & acochar & 1 \\
\hline & desfechar & 1 & desaparelhar & 1 \\
\hline & firmar & 1 & deslaçar & 1 \\
\hline & arribar & 1 & estrupir & 1 \\
\hline & praguejar & 1 & ganter & 1 \\
\hline & disputar & 1 & Ih'ar & 1 \\
\hline & curtir & 1 & tergiversar & 1 \\
\hline
\end{tabular}




\begin{tabular}{|c|c|c|c|c|}
\hline & visitar & 1 & telefonar & 1 \\
\hline & guiar & 1 & apartear & 1 \\
\hline & persuadir & 1 & rouxinolear & 1 \\
\hline & entreter & 1 & desamarrar & 1 \\
\hline & costumar & 1 & coligir & 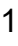 \\
\hline & solicitar & 1 & capitanear & 1 \\
\hline & pilhar & 1 & treplicar & 1 \\
\hline & ludibriar & 1 & reivindicar & 1 \\
\hline & constituir & 1 & depreciar & 1 \\
\hline & dependurar & 1 & enunciar & 1 \\
\hline & comportar & 1 & avocar & 1 \\
\hline & garantir & 1 & sentouser & 1 \\
\hline & cobrar & 1 & rumar & 1 \\
\hline & apinhar & 1 & delegar & 1 \\
\hline & intimar & 1 & ratificar & 1 \\
\hline & utilizar & 1 & aquiescer & 1 \\
\hline & publicar & 1 & sobrelevar & 1 \\
\hline & consertar & 1 & escanchar & 1 \\
\hline & cozinhar & 1 & bisar & 1 \\
\hline$V$ & legitimar & 1 & legalizar & 1 \\
\hline$\theta$ & desafiar & 1 & desapear & 1 \\
\hline 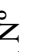 & afrontar & 1 & recambiar & 1 \\
\hline$=$ & estabelecer & 1 & tomou4her & 1 \\
\hline 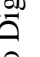 & recitar & 1 & engulhar & 1 \\
\hline & emprestar & 1 & ressalvar & 1 \\
\hline 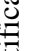 & desprender & 1 & reassumir & 1 \\
\hline 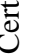 & ressurgir & 1 & planejar & 1 \\
\hline & destruir & 1 & mofar & 1 \\
\hline$\frac{E}{1}$ & furtar & 1 & afolear & 1 \\
\hline & abatir & 1 & esgaravatar & 1 \\
\hline & desarmar & 1 & esbugalhar & 1 \\
\hline & descruzar & 1 & esporar & 1 \\
\hline & ofegar & 1 & embiocar & 1 \\
\hline & berrar & 1 & azuar & 1 \\
\hline & escorregar & 1 & garabulhar & 1 \\
\hline & borrifar & 1 & affirmar & 1 \\
\hline & espelhar & 1 & cahir & 1 \\
\hline & traduzir & 1 & sahir & 1 \\
\hline & transpirar & 1 & posuar & 1 \\
\hline & clamar & 1 & desembrulhar & 1 \\
\hline & embalsamar & 1 & antegostar & 1 \\
\hline & tatear & 1 & adocicar & 1 \\
\hline & entristecer & 1 & canalizar & 1 \\
\hline & rodopiar & 1 & conjugar & 1 \\
\hline & transmitir & 1 & apelidar & 1 \\
\hline & reservar & 1 & adaptar & \\
\hline
\end{tabular}




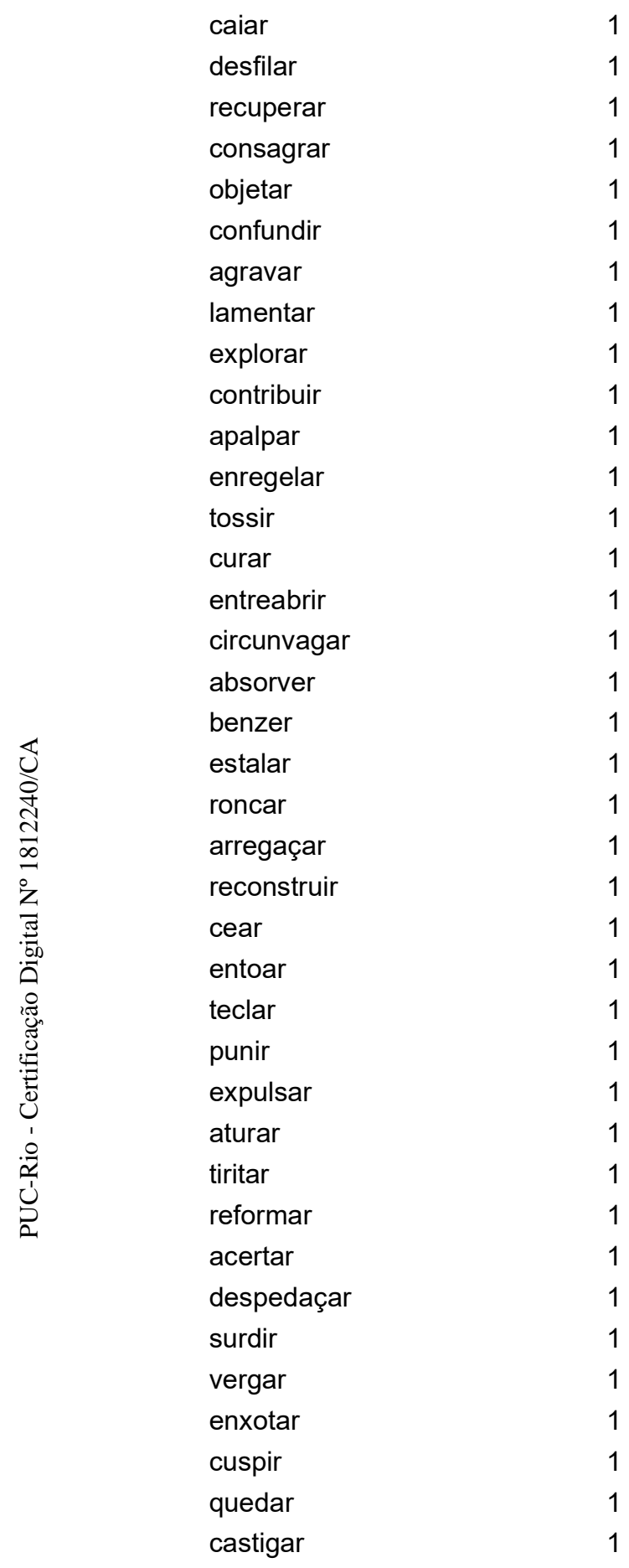

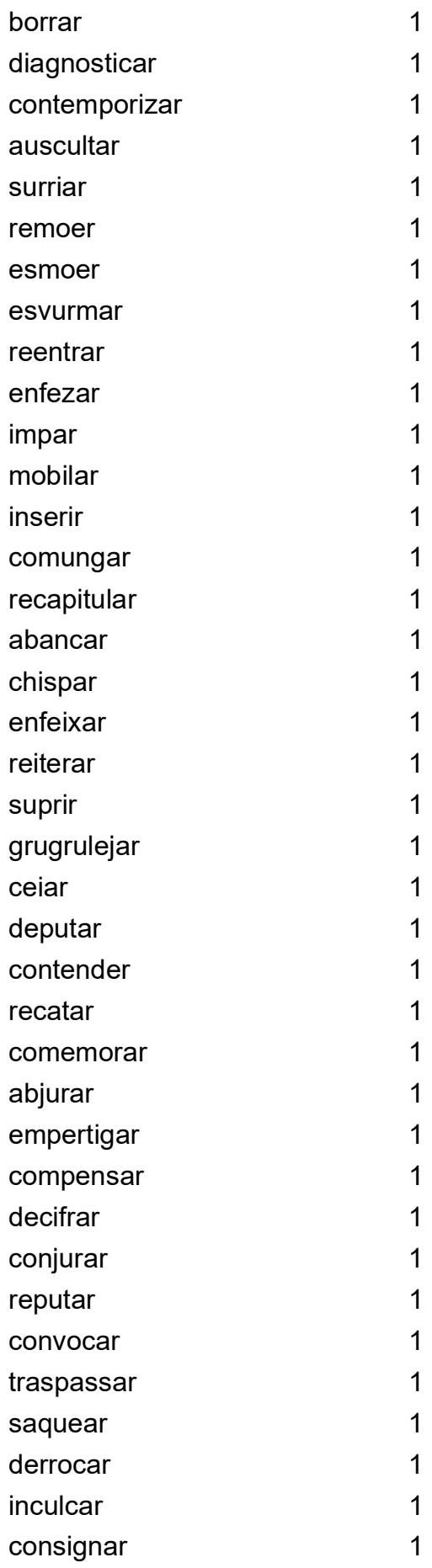




\section{Apêndice 8 - Lista de obras do corpus}

\begin{tabular}{|c|c|}
\hline Código & Autor \\
\hline AdoCam & Adolfo Caminha \\
\hline AluAze & Aluísio Azevedo \\
\hline AlvdAze & Álvares de Azevedo \\
\hline AlvPei & Alvarenga Peixoto \\
\hline ArtAze & Artur Azevedo \\
\hline BasGam & Basílio da Gama \\
\hline BerGui & Bernardo Guimarães \\
\hline CasAlv & Castro Alves \\
\hline ClaMCos & Cláudio Manoel da Costa \\
\hline CoeNet & Coelho Neto \\
\hline EucCun & Euclides da Cunha \\
\hline FraTav & Franklin Távora \\
\hline GreMat & Gregório de Matos \\
\hline HumCam & Humberto de Campos \\
\hline IngSou & Inglês de Sousa \\
\hline JMdM & $\begin{array}{l}\text { Joaquim Manuel de } \\
\text { Macedo }\end{array}$ \\
\hline JoadRio & João do Rio \\
\hline JoaNab & Joaquim Nabuco \\
\hline JosdAle & José de Alencar \\
\hline
\end{tabular}

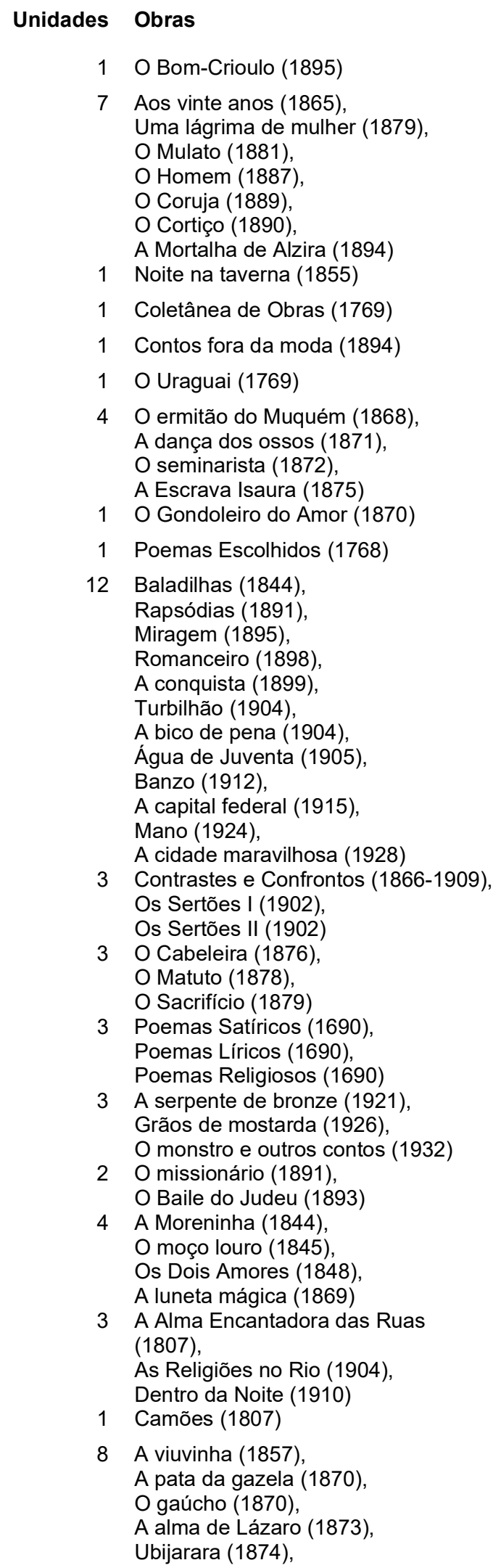




$\begin{array}{ll}\text { JulLAlm } & \text { Júlia Lopes de Almeida } \\ \text { JulRib } & \text { Júlio Ribeiro } \\ \text { LimBar } & \text { Lima Barreto }\end{array}$

MacAss Machado de Assis
O sertanejo (1875),

Como e porque sou romancista (1893)

2 A viúva Simões (1895), A falência (1901)

1 A Carne (1888)

4 Recordações do escrivão Isaías Caminha (1909), Triste Fim de Policarpo Quaresma (1911), Clara dos anjos (1948),

O Homem que Sabia Javanês e Outros Contos (1997)

158 Três tesouros perdidos (1858), O jornal e o livro (1859),

Aquarelas (1859),

A reforma pelo jornal (1859), Bagatela (1859),

Crônicas do Dr. Semana (1861), Comentários da semana (1861),

O país das quimeras (1862),

Crônicas (O Futuro) (1862),

Questão de vaidade (1864),

$\mathrm{O}$ anjo das donzelas (1864),

Virginius (1864),

Ao acaso (1864),

Casada e viúva (1864),

Cinco mulheres (1865),

Suplício de uma mulher (1865),

O que são as moças (1866),

Uma excursão milagrosa (1866),

A pianista (1866),

Diana (1866),

Fernando e Fernanda (1866)

Astúcias de marido (1866),

Os trabalhadores do mar (1866),

O oráculo (1866),

Felicidade pelo casamento (1866),

O pai (1866),

História de uma lágrima (1867),

O último dia de um poeta (1867),

Onda (1867),

Possível e impossível (1867),

Francisca (1867),

Cartas Fluminenses (1867)

O carro no. 13 (1868),

Não é mel para boca de asno (1868),

$\mathrm{O}$ anjo Rafael (1869),

O capitão Mendonça (1870),

Luís Soares (1870),

Confissões de uma viúva moça

(1870),

Linha reta e linha curva (1870),

Miss Dollar (1870),

A mulher de preto (1870),

O rei dos caiporas (1870),

Frei Simão (1870),

A vida eterna (1870),

O segredo de Augusta (1870),

Oliver Twist (1870),

Badaladas (1871),

O caminho de Damasco (1871),

Ayres e Vergueiro (1871),

Mariana (1871),

Almas agradecidas (1871),

Ressurreição (1872), 
Rui de Leão (1872),

Uma águia sem asas (1872),

Uma loureira (1872),

Quem não quer ser lobo... (1872),

Qual dos dois (1872),

Decadência de dois grandes homens

(1873),

Ernesto de tal (1873),

Nem uma nem outra (1873),

A parasita azul (1873),

Ponto de Vista (1873),

Quem conta um conto (1873),

As bodas de Luis Duarte (1873),

O relógio de ouro (1873),

Aurora sem dia (1873),

Um Homem superior (1873),

Tempo de crise (1873),

Valério (1874),

Os óculos de Pedro Antão (1874),

Miloca (1874),

Um dia de entrudo (1874),

A Mão e a Luva (1874),

Muitos anos depois (1874),

História de uma fita azul (1875),

Um esqueleto (1875),

O Visconde de Castilho (1875),

Antes que cases (1875),

$O$ sainete (1875),

A última receita (1875),

A mágoa do infeliz Cosme (1875),

Brincar com fogo (1875),

História de quinze dias (1876),

Longe dos olhos (1876),

O astrólogo (1876),

Encher tempo (1876),

Sem olhos (1876),

Helena (1876),

D. Mônica (1876),

To be or not to be (1876),

Um ambicioso (1877),

Um almoço (1877),

Silvestre (1877),

Notas semanais (1878),

O machete (1878),

Antes da missa (1878),

Um cão de lata ao rabo (1878),

História dos Trinta Dias (1878),

Folha rota (1878),

laiá Garcia (1878),

Conversão de um avaro (1878),

Dívida extinta (1878),

A herança (1878),

O Califa de Platina (1878),

Filosofia de um par de botas (1878),

Elogio da vaidade (1878),

A chave (1879),

Um para o outro (1879),

O caso da viúva (1881),

A mulher pálida (1881),

Memórias póstumas de Brás Cubas

(1881),

Cherchez la femme (1881),

O imortal (1882),

A sereníssima república (1882),

$\mathrm{O}$ anel de Polícrates (1882),

O alienista (1882),

$\mathrm{Na}$ arca (1882), 
A chinela turca (1882),

O espelho (1882),

Teoria do medalhão (1882),

Letra vencida (1882),

Verba testamentária (1882),

O programa (1882),

Uma visita de Alcebíades (1882),

O empréstimo (1882),

O segredo do bonzo (1882),

D. Benedita (1882),

Três consequências (1883),

Médico é remédio (1883),

Questões de maridos (1883),

$O$ destinado (1883),

Vidros quebrados (1883),

A idéia do Ezequiel Maia (1883),

História comum (1883),

Balas de estalo (1883),

Troca de datas (1883),

José de Alencar (1883)

Cantiga velha (1883),

O melhor remédio (1884),

Entre duas datas (1884),

Uma carta (1884),

A carteira (1884),

O caso do Romualdo (1884),

Histórias sem Data (1884),

Vinte Anos! Vinte Anos! (1884),

A viúva Sobral (1884),

A cartomante (1884),

Trina e una (1884),

O contrato (1884),

Viagem à roda de mim mesmo

(1885),

Só (1885),

Casa velha (1885)

Habilidoso (1885),

Um dístico (1886),

Pobre cardeal (1886),

Terpsícore (1886),

Curta história (1886),

Quincas Borba (1886),

Antes a rocha Tarpéia (1887),

Sales (1887), Identidade (1887),

Joaquim Serra (1888),

O futuro dos argentinos (1888),

Bons dias (1888),

Dona Jucunda (1889),

Como se inventaram os almanaques

(1890),

Pobre Finoca! (1891),

A semana (1892),

Entre 1892 e 1894 (1892),

Uma partida (1892),

O caso Barreto (1892),

Um sonho e outro sonho (1892),

Vênus! Divina Vênus! (1893),

Henrique Chaves (1893),

Um quarto de século (1893),

A inglesinha Barcelos (1894),

João Fernandes (1894),

Orai por ele! (1895),

Uma noite (1895),

O diplomático (1896),

Um apólogo (1896),

Adão e Eva (1896),

Um homem célebre (1896), 


$\begin{array}{ll}\text { ManAAIm } & \begin{array}{l}\text { Manuel Antonio de } \\ \text { Almeida } \\ \text { MandOPael de Oliveira Paiva }\end{array} \\ \text { MardAnd } & \text { Mário de Andrade } \\ \text { MFdR } & \text { Maria Firmina dos Reis } \\ \text { OlaBil } & \text { Olavo Bilac } \\ \text { PauSet } & \text { Paulo Setúbal } \\ \text { RauPom } & \text { Raul Pompéia } \\ & \\ \text { TomAGon } & \text { Tomás Antônio Gonzaga } \\ \text { VisTau } & \text { Visconde de Taunay }\end{array}$

Uns braços (1896),

A desejada das gentes (1896), Viver! (1896),

A causa secreta (1896),

O cônego ou Metafísica do estilo (1896),

Trio em Lá menor (1896),

O enfermeiro (1896),

Entre santos (1896),

D. Paula (1896),

Conto de escola (1896),

Henrique Lombaerts (1897),

Uma por outra (1897),

Flor anônima (1897),

O Velho Senado (1898),

Dom Casmurro (1899),

Missa do galo (1899),

O caso da vara (1899),

Eterno! (1899),

Papéis velhos (1899),

Um erradio (1899),

O dicionário (1899),

Idéias do canário (1899),

Lágrimas de Xerxes (1899),

Esaú e Jacó (1904),

Pílades e Orestes (1906),

Maria Cora (1906),

Um incêndio (1906),

Evolução (1906),

O escrivão Coimbra (1906),

Pai contra mãe (1906),

Anedota do cabriolet (1906),

Marcha fúnebre (1906),

Suje-se gordo! (1906),

Um capitão de voluntários (1906),

Umas férias (1906),

Memorial de Aires (1908),

Casa, não casa (1975),

O passado (1976),

A melhor das noivas (1977)

1 Memórias de um sargento de milícias (1852)

3 Contos (1888),

Dona Guidinha do Poço (1891),

A afilhada (1899)

3 Amar, verbo intransitivo (1927), Macunaíma (1928), Os filhos da Candinha (1943)

1 Úrsula (1859)

1 Contos para velhos (1897)

3 A Marquesa de Santos (1925), Os irmãos Leme (1933),

O sonho das esmeraldas (1935)

4 As jóias da Coroa (1882), Uma tragédia no Amazonas (1882), 14 de julho na roça (1883),

O Ateneu (1888)

2 Cartas Chilenas (1786), Marília de Dirceu (1792)

4 Inocência (1872),

A retirada da Laguna, narrativa de campanha (1874),

No declínio (1889),

Ao Entardecer (1901) 